\title{
Brachiopods Near the Permian-Triassic Boundary in South China
}

\section{GUIRON}

(RICHARD E. GRANT

SMITHSONIAN CONTRIBUTIONS TO PALEOBIOLOGY - NUMBER 76 


\title{
SERIES PUBLICATIONS OF THE SMITHSONIAN INSTITUTION
}

Emphasis upon publication as a means of "diffusing knowledge" was expressed by the first Secretary of the Smithsonian. In his formal plan for the institution, Joseph Henry outlined a program that included the following statement: "It is proposed to publish a series of reports, giving an account of the new discoveries in science, and of the changes made from year to year in all branches of knowledge." This theme of basic research has been adhered to through the years by thousands of titles issued in series publications under the Smithsonian imprint, commencing with Smithsonian Contributions to Knowledge in 1848 and continuing with the following active series:

\author{
Smithsonian Contributions to Anthropology \\ Smithsonian Contributions to Botany \\ Smithsonian Contributions to the Earth Sciences \\ Smithsonian Contributions to the Marine Sciences \\ Smithsonian Contributions to Paleobiology \\ Smithsonian Contributions to Zoology \\ Smithsonian Folklife Studies \\ Smithsonian Studies in Air and Space \\ Smithsonian Studies in History and Technology
}

In these series, the Institution publishes small papers and full-scale monographs that report the research and collections of its various museums and bureaux or of professional colleagues in the world of science and scholarship. The publications are distributed by mailing lists to libraries, universities, and similar institutions throughout the world.

Papers or monographs submitted for series publication are received by the Smithsonian Institution Press, subject to its own review for format and style, only through departments of the various Smithsonian museums or bureaux, where the manuscripts are given substantive review. Press requirements for manuscript and art preparation are outlined on the inside back cover.

Robert McC. Adams

Secretary

Smithsonian Institution 
SMITHSONIAN CONTRIBUTIONS TO PALEOBIOLOGY • NUMBER 76

\section{Brachiopods Near the Permian-Triassic Boundary in South China}

Guirong Xu and Richard E. Grant

SMITHSONIAN INSTITUTION PRESS

Washington, D.C.

1994 


\section{A B S T R A C T}

$\mathrm{Xu}$, Guirong, and Richard E. Grant. Brachiopods Near the Permian-Triassic Boundary in South China. Smithsonian Contributions to Paleobiology, number 76, 68 pages, 54 figures, 7 tables, 1994.-Sixty-eight genera and 164 species in the Changxingian Stage and 12 genera and 20 species in the lower Griesbachian Stage are recorded on the basis of brachiopod fossils collected from 32 sections in South China and from review of the Chinese literature. Of these, 24 genera and 34 species are described here, including three new genera (Fanichonetes, Prelissorhynchia, and Rectambitus) and 24 new species (Acosarina strophiria, Enteletes asymmatrosis, Peltichia schizoloides, Derbyia pannuciella, Perigeyerella altilosina, Chonetinella cursothonia, C. volitanliopsis, Fanichonetes campigia, Cathaysia spiriferoides, Uncinunellina multicostifera, Prelissorhynchia triplicatioid, Cyrolexis antearcus, Cyrolexis beccojectus, Cartorhium xikouensis, C. twifurcifer, Callispirina rotundella, Araxathyris subpentagulata, A. beipeiensis, Spirigerella discsella, S. ovaloides, Squamularia formilla, Hustedia orbicostata, Rostranteris ptychiventria, and Notothyris bifoldes).

The Cathaysia chonetoides-Chonetinella substrophomenoides assemblage zone and the Cathaysia sinuata-Waagenites barusiensis assemblage zone represent respectively faunas of the lower Changxingian and the upper Changxingian in clastic lithofacies; whereas the Peltichia zigzag-Prelissorhynchia triplicatioid assemblage zone and the Spirigerella discusellaAcosarina minuta assemblage zone represent faunas in limestone lithofacies. The Crurithyris pusilla-Lingula subcircularis assemblage zone and Permian-type brachiopods are present in the lower Griesbachian.

The Changxingian brachiopod fauna can be correlated with the Dorashamian fauna of Armenia; the brachiopod faunas of the Ali Bashi Formation, North-West Iran; unit 7 of the Hambast Formation, Central Iran; and the upper part of the Bellerophon Formation of the Southern Alps.

The genera Cathaysia, Peltichia, and Prelissorhynchia are especially characteristic of the Cathaysia Tethyan Subprovince. In contrast, the West Tethyan Subprovince is characterized by the genera Costiferina, Ombonia, Comelicania, and many other species. Four brachiopod ecofacies are recognized in the Changxingian of South China: (1) antibiohermal dwellers; (2) calcareous substratum dwellers; (3) biohermal dwellers; and (4) ubiquitous substrate dwellers. In the lower Griesbachian, the brachiopod fauna of Lingula and Crurithyris spreads across the entire Tethys and is called the Circum-Pangaea brachiopod fauna.

Massive extinction of brachiopod faunas occurred at the close of the Changxingian, with only a few Permian-types surviving into the early Griesbachian, and they completely vanished after the early Griesbachian except for harbingers of Mesozoic brachiopods.

OFFICIAL PUBLICATION DATE is handstamped in a limited number of initial copies and is recorded in the Institution's annual report, Smithsonian Year. SERIES COVER DESIGN: The trilobite Phacops rana Green.

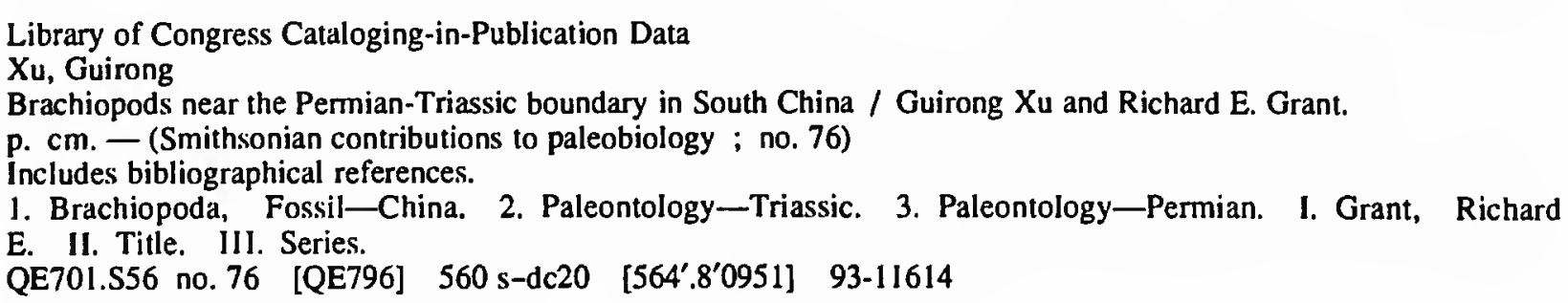

(2) The paper used in this publication meets the minimum requirements of the American National Standard for Permanence of Paper for Printed Library Materials Z39.48-1984. 


\section{Contents}

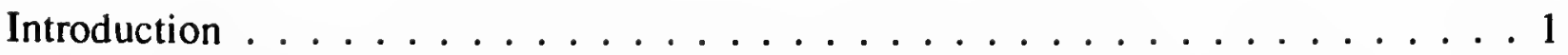

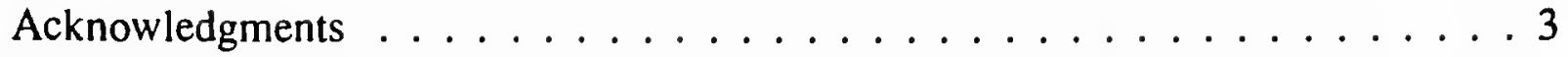

Zonation and Correlation . . . . . . . . . . . . . . . 3

Relationship with Other Biozones . . . . . . . . . . . . 6

Correlations within Tethys ............... 8

Brachiopod Provinces and Biofacies . . . . . . . . . . . . 12

Biofacies . . . . . . . . . . . . . . . . . . 12

Changxingian Brachiopod Biofacies . . . . . . . . . . . 12

Brachiopod Biofacies of the Lower Griesbachian . . . . . . . . . . . . 13

Extinction and Evolution ................... 13

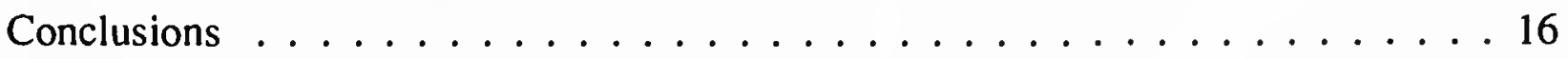

Systematic Listing . . . . . . . . . . . . . . . . . . . . 17

Order ORTHIDA Schuchert and Cooper, $1932 \ldots \ldots \ldots 18$

Superfamily RHIPIDOMELLOIDEA Schuchert, $1913 \ldots \ldots \ldots$. . . . . . . 18

Family SCHIZOPHORIIDAE Schuchert and LeVene, $1929 \ldots \ldots$. . . . . . . 18

Genus Acosarina Cooper and Grant, 1969 . . . . . . . . . . 18

Acosarina strophiria sp. nov. . . . . . . . . . . . . 18

Superfamily ENTELETOIDEA Waagen, $1884 \ldots \ldots \ldots 19$

Family ENTELETIDAE Waagen, $1884 \ldots \ldots \ldots$. . . . . . . . 19

Genus Enteletes Fischer de Waldheim, 1825 . . . . . . . 19

Enteletes asymmatrosis sp. nov. . . . . . . . . . . . 19

Genus Peltichia Jing and Liao, $1981 \ldots \ldots \ldots$

Peltichia schizoloides sp. nov. . . . . . . . . . 21

Order STROPHOMENIDA Opik, $1934 \ldots \ldots \ldots \ldots . \ldots \ldots . \ldots \ldots$

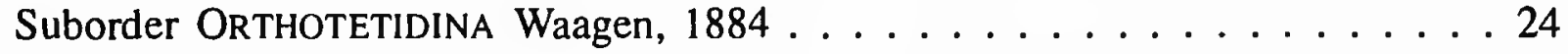

Superfamily DERBYIOIDEA Stehli, $1954 \ldots \ldots \ldots \ldots \ldots$

Family DerbyidAE Stehli, $1954 \ldots \ldots \ldots \ldots . \ldots \ldots$

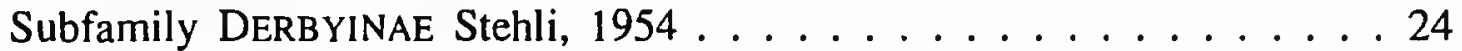

Genus Derbyia Waagen, $1884 \ldots \ldots \ldots$. . . . . . . . . 24

Derbyia pannuciella sp. nov. . . . . . . . . . . . . . . 24

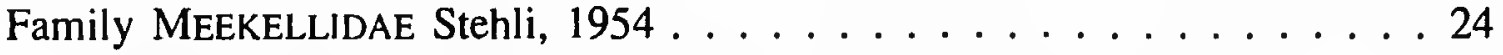

Genus Meekella White and St. John, $1867 \ldots \ldots \ldots . \ldots . \ldots 24$

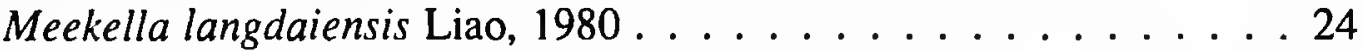

Superfamily ORTHOTETOIDEA Waagen, $1884 \ldots \ldots \ldots \ldots$

Family ORTHOTETIDAE Waagen, $1884 \ldots \ldots \ldots \ldots \ldots$

Genus Perigeyerella Wang, $1955 \ldots \ldots \ldots \ldots$

Perigeyerella altilosina sp. nov. . . . . . . . . . . . 26

Suborder CHONETIDINA Muir-Wood, 1955 . . . . . . . . . . . . . . 27

Superfamily CHONETOIDEA Bronn, 1862 . . . . . . . . . . . . . 27

Family RugosochonetIDAE Muir-Wood, $1962 \ldots \ldots$. . . . . . . . 27

Subfamily ChONETINELlinaE Muir-Wood, $1962 \ldots \ldots \ldots$. . . . . . 27

Genus Chonetinella Ramsbottom, 1952 . . . . . . . . . . . . 27

Chonetinella cursothornia sp. nov. . . . . . . . . . . . . 27

Chonetinella volitanliopsis $(\mathrm{Xu}, 1987) \ldots \ldots \ldots \ldots . \ldots . \ldots 28$

Subfamily RUGOSOCHONETINAE Muir-Wood, 1962 . . . . . . . . . . 29

Fanichonetes gen. nov. . . . . . . . . . . . . . . . . . . 29 
Fanichonetes campigia sp. nov. . . . . . . . . . . . . . . . . 29

Suborder Productidina Waagen, $1883 \ldots \ldots$. . . . . . . . . . . . 29

Superfamily PRODUCTOIDEA Gray, $1840 \ldots \ldots$. . . . . . . . . . . . . . 29

Family CHONETELLIDAE Likharev, $1960 \ldots \ldots$. . . . . . . . . . . 29

Genus Cathaysia Ching, $1966 \ldots \ldots$. . . . . . . . . . 29

Cathaysia sinuata Chan, $1979 \ldots \ldots$. . . . . . . . . . . 31

Cathaysia spiriferoides sp. nov. . . . . . . . . . . . . . 32

Cathaysia obicularis Liao, $1980 \ldots \ldots$. . . . . . . . 34

Superfamily RICHTHOFENIOIDEA Waagen, $1885 \ldots \ldots \ldots$. . . . . . . 34

Richthofeniid, genus and species undetermined . . . . . . . . . . . . . 34

Order RHYNCHONELLIDA Kuhn, 1949 . . . . . . . . . . . . . . . . . . . . 35

Superfamily WeLlERELLOIDEA Xu and Liu, $1983 \ldots \ldots \ldots \ldots$. . . . . . 35

Family WELLERELLIDAE Likharev, 1956 . . . . . . . . . . . . 35

Genus Uncinunellina Grabau, $1932 \ldots \ldots$. . . . . . . . . . 35

Uncinunellina multicostifera sp. nov. . . . . . . . . . . . 35

Family PonTISIIDAE Cooper and Grant, 1976 . . . . . . . . . . 36

Subfamily LISSORHYNCHIINAE Xu and Liu, 1983 . . . . . . . . . . . . 36

Prelissorhynchia gen. nov. . . . . . . . . . . . . 36

Prelissorhynchia pseudoutah (Huang, 1933), new combination . . . . 38

Prelissorhynchia triplicatioid sp. nov. . . . . . . . . . . 38

Superfamily STENOSCISMATOIDEA Oehlert, 1887 (1883) . . . . . . . . . . . 39

Family ATRIBONIIDAE Grant, 1965 . . . . . . . . . . . . . . . . 39

Subfamily ATRIBONIINAE Grant, $1965 \ldots$. . . . . . . . . . . . . . 39

Genus Cyrolexis Grant, 1965 . . . . . . . . . . . . . . 39

Cyrolexis antearcus sp. nov. . . . . . . . . . . . 39

Cyrolexis beccojectus sp. nov. . . . . . . . . . . . . . . . . . . 39

Order SPIRIFERIDA Waagen, $1883 \ldots \ldots \ldots \ldots$. . . . . . . . . . 41

Suborder SPIRIFERIDINA Waagen, $1883 \ldots \ldots \ldots \ldots 1$

Superfamily SPIRIFEROIDEA King, $1846 \ldots \ldots \ldots \ldots$. . . . . . . 41

Family SPIRIFERIDAE King, $1846 \ldots \ldots \ldots \ldots \ldots$. . . . . . . . 41

Subfamily NEOSPIRIFERINAE Waterhouse, $1968 \ldots \ldots \ldots$. . . . . . 41

Genus Cartorhium Cooper and Grant, 1976 . . . . . . . . . . . . 41

Cartorhium xikouensis sp. nov. . . . . . . . . . . . . . 44

Cartorhium twifurcifer sp. nov. . . . . . . . . . . . . . . 42

Superfamily CYRTIOIDEA Frederiks, 1924 . . . . . . . . . . . . . . . 43

Family AMBOCOELIIDAE George, $1931 \ldots \ldots$. . . . . . . . . . 43

Genus Crurithyris George, $1931 \ldots \ldots$. . . . . . . . . . 43

Crurithyris pusilla Chan, $1979 \ldots \ldots \ldots$. . . . . . . 43

Suborder SPIRIFERINIDINA Cooper and Grant, 1976 . . . . . . . . . . . . 45

Superfamily SPIRIFERINOIDEA Davidson, $1884 \ldots \ldots \ldots$. . . . . . . . 45

Family PARASPIRIFERINIDAE Cooper and Grant, 1976 . . . . . . . . . . 45

Genus Paraspiriferina Reed, 1944 . . . . . . . . . . . . . . . 45

Paraspiriferina alpha (Huang, 1933) . . . . . . . . . 45

Genus Callispirina Cooper and Muir-Wood, 1951 . . . . . . . . . 47

Callispirina? rotundella sp. nov. . . . . . . . . . . . . 47

Suborder ATHYRIDIDINA Boucot, Johnson, and Staton, 1964 . . . . . . . . . 48

Superfamily ATHYRIDIDOIDEA McCoy, $1844 \ldots \ldots \ldots \ldots$. . . . . . 48

Family ATHYRIDIDAE McCoy, $1844 \ldots \ldots \ldots \ldots$

Subfamily SPIRIGERELLINAE Grunt, $1965 \ldots \ldots \ldots \ldots \ldots$

Genus Araxathyris Grunt, $1965 \ldots \ldots \ldots$. . . . . . . . 48

Araxathyris beipeiensis sp. nov. . . . . . . . . . . . . . 48

Araxathyris subpentangulata sp. nov. . . . . . . . . . . . . 49

Rectambitus gen. nov. . . . . . . . . . . . . . . 50

Rectambitus bisulcatus (Liao, 1980), new combination . . . . . . 50 
Genus Spirigerella Waagen, $1883 \ldots \ldots \ldots \ldots$. . . . . . 51

Spirigerella discusella sp. nov. . . . . . . . . . . . . . 51

Spirigerella guizhouensis (Liao, 1980), new combination . . . . . . 52

Spirigerella ovaloides sp. nov. . . . . . . . . . . . . 54

Spirigerella shuizhutangensis (Chan, 1979), new combination . . . . 56

Genus Tongzithyris Ching, Liao, and Fang, 1974 . . . . . . . . . . 56

Tongzithyris sichuanensis Xu, $1987 \ldots \ldots$. . . . . . . . . 57

Superfamily RETICULARIOIDEA Waagen, $1883 \ldots \ldots \ldots \ldots$

Family ELYTHIDAE Frederiks, $1924 \ldots \ldots$. . . . . . . . . . . . 58

Genus Squamularia Gemmellaro, $1899 \ldots \ldots \ldots$. . . . . . . 58

Squamularia formilla sp. nov. . . . . . . . . . . . . 58

Suborder RETZIIDINA Boucot, Johnson, and Staton, $1964 \ldots \ldots$. . . . . . . . 60

Superfamily RETZIOIDEA Waagen, $1883 \ldots \ldots$. . . . . . . . . 60

Family ReTZIIDAE Waagen, $1883 \ldots \ldots \ldots 60$

Genus Hustedia Hall and Clarke, $1893 \ldots \ldots$. . . . . . . . 60

Hustedia orbicostata sp. nov. . . . . . . . . . . . . 60

Order Terebratulida Waagen, $1883 \ldots \ldots \ldots \ldots$. . . . . . . 61

Superfamily CRYPTONELLOIDEA Thomson, 1926 . . . . . . . . . . .61

Family NOTOTHYRIDIDAE Likharev, 1960 . . . . . . . . . . . . . . 61

Genus Rostranteris Gemmellaro, 1899 . . . . . . . . . . . 61

Rostranteris ptychiventria sp. nov. . . . . . . . . . 661

Genus Notothyris Waagen, 1882 . . . . . . . . . . 63

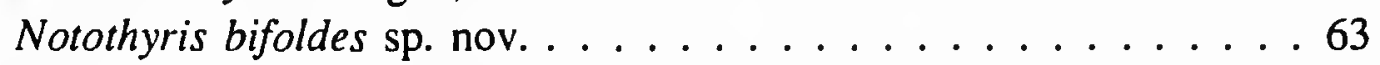

Literature Cited . . . . . . . . . . . . . . . . . . . 66 65 



\title{
Brachiopods Near the Permian-Triassic Boundary in South China
}

\author{
Guirong $X u$ and Richard E. Grant
}

\section{Introduction}

The study of brachiopods near the Permian-Triassic boundary provides fossil evidence useful in establishing and correlating the stratigraphic boundary stratotype of the Permian-Triassic. Such a study also enables one to reconstruct the environment where brachiopods lived and adapted during the passage from the Paleozoic to the Mesozoic and to elucidate the evolutionary relationship between Paleozoic and Mesozoic brachiopods.

Former works that systematically described brachiopods from the Late Permian of South China are by Chao (1927, 1928, 1929) and Huang (1932, 1933). Investigations of coal deposits of the Late Permian and research on the PermianTriassic boundary stratotype in South China in the last decade has provided continued impetus to this line of endeavor. Papers by Chan (in Hou et al., 1979), Liao (1979, 1980a, 1981), Liao and Meng (1986), and Xu (in Yang et al., 1987) reveal that brachiopods are abundant in rocks of Late Permian age in South China and that several Permian-type brachiopods extend into the lowermost Triassic.

This paper deals with the Changxingian Stage (formerly spelled Changhsingian) and the lower Griesbachian Stage brachiopods in South China, based upon materials collected from 32 sites whose locations are shown in Figure 1. (Hereafter, all collection spots will be referred to by their spot number and will not include the reference to Figure 1.)

The study area is situated mainly in the Yangtze platform, which was essentially surrounded by "old lands" (i.e., emergent at the time) during the Late Permian and Early Triassic. North of the area is the North China platform, which was completely above sea level and, at that time, was the source of erosional

Guirong Xu, Paleontology Laboratory, China University of Geosciences, Wuhan, Hubei Province, 430074, China. Richard E. Grant, Department of Paleobiology, National Museum of Natural History, Smithsonian Institution, Washington, D.C. 20560. sediments. The Cathaysia old landmass extended northeastward from the North China platform. The Kangdian old landmass was to the west, and the Yun-Kai old land was located south of the platform. Therefore, during the Late Permian and Early Triassic, this area was a barrier sea basin. Another old landmass, called the Jiangnan old landmass, was located in the middle of the basin. The sedimentary characters to a certain extent relate to that very complicated landform (Figure 3).

The Changxingian Stage with its abundantly preserved brachiopods has several sedimentary types in the Yangtze basin, largely of three types: limestone, silicalite (i.e., particulate chert), or arenite. The Changxing Formation, type section located at Meishan, Changxing County, Zhejiang Province (spot 26), consists of gray to dark medium-bedded pure limestone, bituminous limestone and limy dolomite, and intercalated cherty limestone. The Changxing Formation is most widely distributed in Zhejiang, Sichuan, and North Guizhou, generally in the platform facies of the basin. Chert sediments are represented in the Dalong Formation, whose type locality is at Matan, Geshan County, Guangxi Province (near spot 15), where it is composed of gray or black thin-bedded silicalite, yellowish brown siliceous tuffite, and intercalated siliceous or tufaceous arenite.

Distribution of the Dalong Formation follows closely the distribution of volcaniclastic rocks extending along a narrow belt in South Guizhou, Guangxi, and Hubei Provinces. On the east side of the Kangdian old landmass, the west side of Cathaysia old landmass, and the north side of the Yun-Kai old landmass are mostly arenites of the Xuanwei Formation (type locality is at Xuanwei, Yunnan Province) and the Yanshi Formation (type locality is at the Yanshi section, Longyan County, Fujian Province) (spot 31). The former consists of intercalated terrigenous sediments and the latter is marine arenite containing dark gray, yellowish green, and grayish yellow calcareous siltstone and silty mudstone, interbedded 


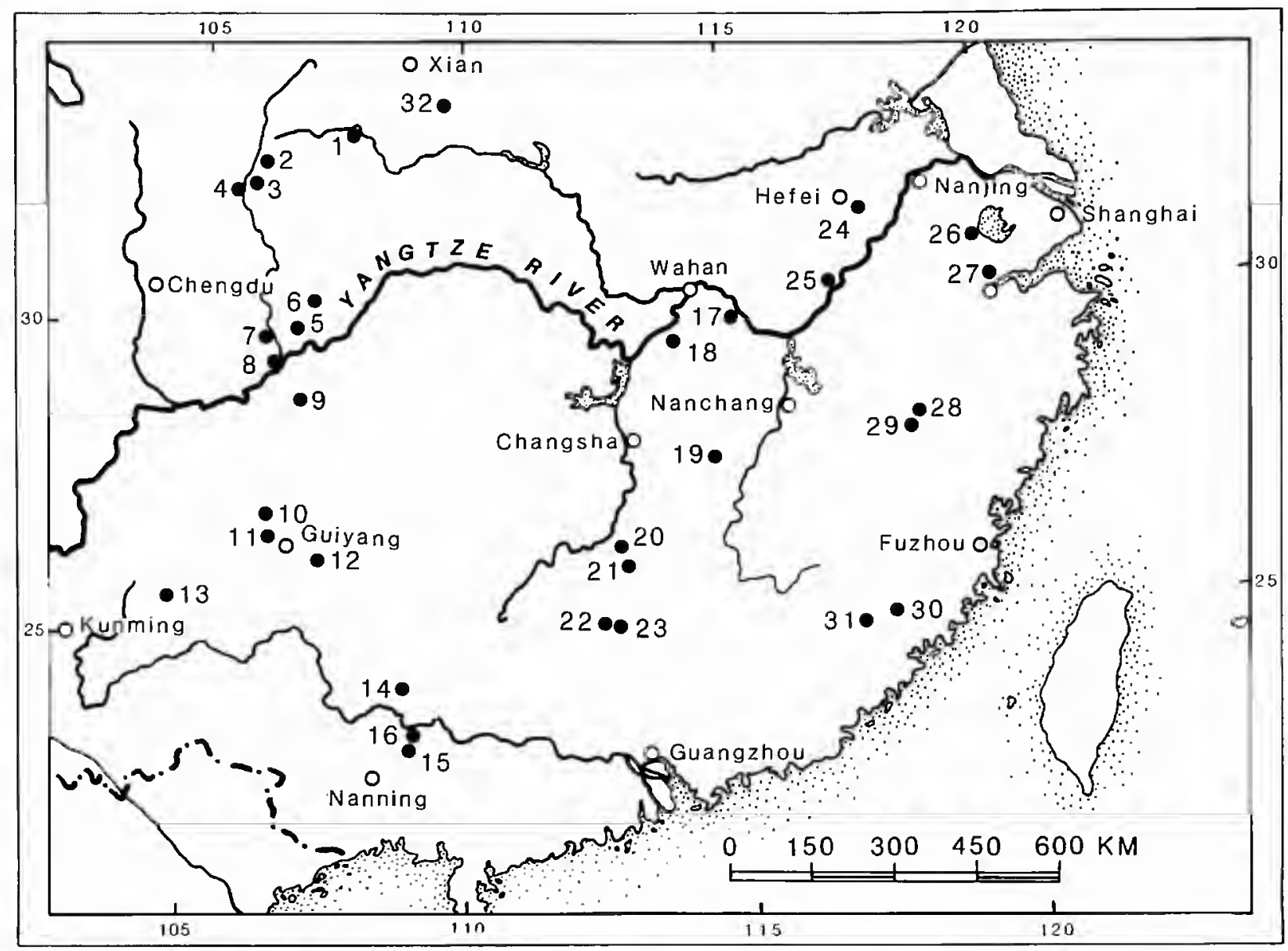

Figure 1.-Distribution of the Permian-Triassic boundary sections of South China.

1. Kucaoping section, Xixiang County, Shaanxi Province

2. Mingxuexia section, Guangyuan County, Sichuan Province

3. Xindianzi section, Guangyuan County, Sichuan Province

4. Shangsi section, Guangyuan County, Sichuan Province

5. Xinjiacao section, Guangan County, Sichuan Province

6. Huayingchan section, Linshui County. Sichuan Province

7. Yanjingxi section, Hechuan County, Sichuan Province

8. Liangfengya section, Zhingqing County, Sichuan Province

9. Banzhuyuan section, Nantong County, Sichuan Province

10. Liuchang section, Qingzhen County, Guizhou Province

11. Yingpanpo section, Guiyang County, Guizhou Province

12. Xiaochehe section, Guiyang County, Guizhou Province

13. Huopu section, Pan County, Guizhou Province

14. Longtoujiang section, Yishan County, Guanxi Province

15. Paoshui section, Laibin County, Guanxi Province

16. Penglaitan section, Laibin County, Guangxi Province
17. Shatian section. Huangshi County, Hubei Province

18. Guanyinshan section, Fuqi County, Hubei Province

19. Baimu section, Yiahun County, Jiangxi Province

20. Jueguangsi section, Laiyang County, Hunan Province

21. Matian section, Yongxi County, Hunan Province

22. Xiaoyuanchong section, Jiahe County, Hunan Province

23. Meitian section, Yizhang County, Hunan Province

24. Majiashan section, Chao County, Anhui Province

25. Yueshan section, Huaining County, Anhui Provonce

26. Meishan section, Changxing County, Zhejiang Province

27. Huangzhishan section, Wuxing County, Zhejiang Province

28. Minfa section, Guangfeng County, Jiangxi Province

29. Xijia section, Shangroa County, Jiangxi Province

30. Yading section, Shangping County, Fujian Province

31. Yanshi section, Longyan County, Fujian Province

32. Xikou section, Zhenan County, Shaanxi Province with fine sandstone and lenses of limestone.

Lower Griesbachian strata, which bear poor brachiopod fossils, are petrographically more uniform than are the underlying Changxingian rocks. They can be divided into two kinds of rocks: limestone and arenite. The lower Daye and the lower Qinglong formations consist mainly of limestone and calcareous mudstone. They occur on the platform facies belt of the basin. The clastic-type strata are dispersed along the margins of old land provinces, such as the Xikou Formation, which is located on the west of Cathaysia, the Kayitou Formation, and the lower Feixianguan Formation, which occurs to the east of the Kangdian old landmass. The Yinkeng Formation is currently becoming known internationally because its reference section is siluated at the same location as the type section of the Changxingian Stage (spot 26). It contains many fossils indicative of the Griesbachian Stage. It overlies the Changxing Formation; therefore, it is a prime candidate for the Permian-Triassic boundary stratotype. It consists of grayish yellow-green calcarcous mudstone intercalated with a few thin-and medium-bedded limestone stringers (Table 1).

Brachiopods from the 32 sections that are recorded in the literature of South China consist of about 68 genera and 164 species in the Changxingian and about 12 genera and 20 species that extend into the lower Griesbachian (Table 6). Permian-type brachiopods are completely absent above the Griesbachian. Twenty-four genera and 34 specics are described in this paper, including 3 new genera and 24 new species. 
TABLE 1. Summary of formations and general lithology near the Permian-Triassic boundary in South China.

\begin{tabular}{|c|c|c|c|c|c|c|}
\hline \multicolumn{2}{|c|}{$\begin{array}{l}\text { Stratigraphic } \\
\text { Units }\end{array}$} & \multirow{2}{*}{$\begin{array}{l}\text { Zhejiang and } \\
\text { Jiangsu Provinces }\end{array}$} & \multirow{2}{*}{$\begin{array}{l}\text { Hubei, Hunan } \\
\text { and Guangxi } \\
\text { Provinces }\end{array}$} & \multirow{2}{*}{$\begin{array}{l}\text { Sichuan } \\
\text { Province }\end{array}$} & \multirow{2}{*}{$\begin{array}{l}\text { Fujian } \\
\text { Province }\end{array}$} & \multirow{2}{*}{$\begin{array}{l}\text { West Guizhou } \\
\text { and Yunnan } \\
\text { Provinces }\end{array}$} \\
\hline Series & Stage & & & & & \\
\hline 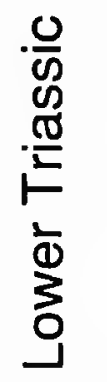 & 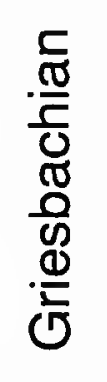 & $\begin{array}{l}\text { Yinkeng or lower } \\
\text { Lower Qinglong Fm.: } \\
\text { calcareous mud- } \\
\text { stone intercalated } \\
\text { thin and medium } \\
\text { limestone }\end{array}$ & $\begin{array}{l}\text { Lower Daye Fm.: } \\
\text { thin and medium } \\
\text { bedded limestone } \\
\text { interbedded } \\
\text { calcareous and } \\
\text { silt mudstone }\end{array}$ & $\begin{array}{l}\text { Lower } \\
\text { Feixianguan } \\
\text { Fm.: } \\
\text { purple mud- } \\
\text { stone and } \\
\text { grey mudy } \\
\text { limestone }\end{array}$ & $\begin{array}{l}\text { Lower Xikou } \\
\text { Fm.: } \\
\text { calcareous } \\
\text { siltstone } \\
\text { and sand- } \\
\text { stone, } \\
\text { mudstone }\end{array}$ & $\begin{array}{l}\text { Kayitou Fm.: } \\
\text { sandstone, } \\
\text { siltstone }\end{array}$ \\
\hline 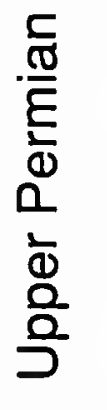 & 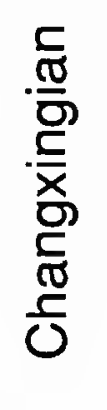 & $\begin{array}{l}\text { Changxing Fm: } \\
\text { limestone and chert } \\
\text { limestone }\end{array}$ & $\begin{array}{l}\text { Dalong Fm.: } \\
\text { silicalite inter- } \\
\text { calated lime- } \\
\text { stone and mud- } \\
\text { stone }\end{array}$ & $\begin{array}{l}\text { Changxing } \\
\text { Fm.: } \\
\text { limestone } \\
\text { intercalated } \\
\text { siliceous } \\
\text { limestone } \\
\text { and } \\
\text { calcareous } \\
\text { mudstone }\end{array}$ & $\begin{array}{l}\text { Yanshi Fm.: } \\
\text { calcareous } \\
\text { siltstone } \\
\text { and } \\
\text { mudstone }\end{array}$ & $\begin{array}{l}\text { Upper Xuan- } \\
\text { wei Fm.: } \\
\text { siltstone } \\
\text { intercalated } \\
\text { coal beds }\end{array}$ \\
\hline
\end{tabular}

\section{ACKNOWLEDGMENTS}

Guirong $\mathrm{Xu}$ was a senior postdoctoral fellow at the Smithsonian Institution and received support from the Institution's Office of Fellowships and Grants, 1985-86. He expresses special thanks to the Smithsonian Institution and his supervisor and coauthor Richard E. Grant. The Department of Paleobiology, National Museum of Natural History (NMNH), Smithsonian Institution, provided space, equipment, and its huge collections that gave him an opportunity to compare specimens collected from South China to the collections from other Tethyan areas. Xu was especially pleased to have the opportunity to visit the classic Permian area of West Texas, guided by B.R. Wardlaw of the United States Geological Survey (USGS), R.E. Grant (NMNH), and D.M. Rohr and S. Rudine of Sul Ross State University.

G. Arthur Cooper and Norman D. Newell contributed through their useful discussions of stratigraphy and brachiopods. Rex A. Doescher provided us the use of his database at the Smithsonian International Brachiopod Information Center, which helped to make the manuscript consistent. The typescript was reviewed for scientific content by Yang Zunyi, China University of Geosciences, Stanley S. Beus, Northern Arizona University, and Bruce R. Wardlaw, United States Geological Survey, whom we thank for substantial insights.

The collections of brachiopods described in this paper from 32 sections of South China were contributed by teachers and students of the Wuhan College of Geology who worked in the field every summer from 1980 to 1984. Data on stratigraphic sections were published by Z.Y. Yang et al. (1987). Other fossils referred to in this paper include ammonoids identified by F.Q. Yang, conodonts by M.H. Ding, and fusulinids by R.G. Gu. We appreciate their help greatly.

Illustrated specimens are deposited in the collections of the former United States National Museum (USNM), now in the National Museum of Natural History, Smithsonian Institution. Washington. D.C.

\section{Zonation and Correlation}

Several schemes of brachiopod zonations near the PermianTriassic boundary in South China have been advanced during the past two decades (Table 2). Summing up the brachiopod sequences of the 32 sections as well as information taken from other works. we put forward the brachiopod zonation presented in the left column in Table 2. Brachiopod faunas are closely related to lithofacies in the Changxingian, so brachiopod assemblage zones are linked to the several lithofacies of that stage.

1. Cathaysia chonetoides (Chao)-Chonetinella substrophomenoides (Huang) assemblage zone (abbreviation $C$ $C)$ : The representative brachiopod fauna in the clastic lithofacies of the lower Changxingian is not highly diverse, being composed mainly of Chonetoidea, such as Waagenites, Chonetinella, and Fanichonetes, new genus; Chonetellidae, such as Cathaysia; and Meekellidae, such as Orthothetina and Perigeyerella. The following species play important roles in this assemblage zone: Cathaysia chonetoides (Chao), $C$. 
TABLE 2.-The course of zonation change of brachiopods near the Permian-Triassic boundary in South China.

\begin{tabular}{|c|c|c|c|c|c|c|}
\hline \multirow{2}{*}{\multicolumn{2}{|c|}{$\begin{array}{c}\text { Stratigraphic } \\
\text { Units }\end{array}$}} & \multirow{3}{*}{ Hou et al. 1980} & \multirow{3}{*}{ Liao, 1980} & \multirow{3}{*}{$\begin{array}{c}\text { Yang, et al. } \\
1987\end{array}$} & \multicolumn{2}{|c|}{ this paper } \\
\hline & & & & & \multirow{2}{*}{$\begin{array}{l}\text { clastic } \\
\text { lithofacies }\end{array}$} & \multirow{2}{*}{$\begin{array}{l}\text { limestone } \\
\text { lithofacies }\end{array}$} \\
\hline Series & Stage & & & & & \\
\hline 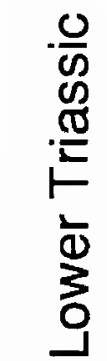 & 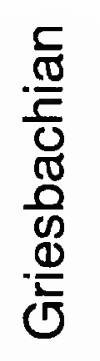 & & & $\begin{array}{l}\text { Crurithyris } \\
\text { speciosa-- } \\
\text { Lingula sub- } \\
\text { circularis } \\
\text { assemblage } \\
\text { zone }\end{array}$ & \multicolumn{2}{|c|}{$\begin{array}{l}\text { Crunithyris pusilla-- } \\
\text { Lingula subcircularis } \\
\text { assemblage zone }\end{array}$} \\
\hline \multirow{2}{*}{$\begin{array}{l}\frac{c}{\mathbb{0}} \\
\frac{E}{E} \\
\frac{1}{\Phi} \\
\square \\
\frac{1}{\Phi} \\
\frac{0}{0} \\
\frac{0}{D}\end{array}$} & \multirow{2}{*}{ 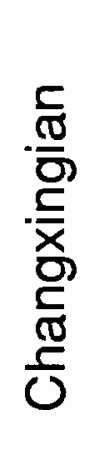 } & $\begin{array}{l}\text { Cathaysia sinuata, } \\
\text { Oldhamina minor, } \\
\text { Crunithyris pusilla, } \\
\text { Hustedia indica }\end{array}$ & \multirow{2}{*}{$\begin{array}{l}\text { Enteletina } \\
\text { zigzag*-.-. } \\
\text { Cathaysia } \\
\text { sulcatifera** } \\
\text { assemblage }\end{array}$} & $\begin{array}{l}\text { Waagenites } \\
\text { barusiensis- } \\
\text { Crunithyris } \\
\text { pusilla } \\
\text { assemblage }\end{array}$ & $\begin{array}{l}\text { Cathaysia } \\
\text { sinuata-- } \\
\text { Waagenites } \\
\text { barusiensis } \\
\text { assemblage }\end{array}$ & $\begin{array}{l}\text { Spingerella } \\
\text { discusella-- } \\
\text { Acosarina } \\
\text { minuta } \\
\text { assemblage }\end{array}$ \\
\hline & & $\begin{array}{l}\text { Tschernyschewia } \\
\text { geniculata, } \\
\text { Enteletina sinensis*, } \\
\text { Meekella } \\
\text { kueichowensis }\end{array}$ & & $\begin{array}{c}\text { Enteletina } \\
\text { zigzag*-- } \\
\text { Neowellerella } \\
\text { pseudoutah } \\
\text { assemblage }\end{array}$ & $\begin{array}{l}\text { Cathaysia } \\
\text { chonetoides-- } \\
\text { Chonetinella } \\
\text { substropho- } \\
\text { menoides } \\
\text { assemblage }\end{array}$ & $\begin{array}{l}\text { Peltichia } \\
\text { zigzag-- } \\
\text { Prelissorhynchia } \\
\text { triplicatioid } \\
\text { assemblage }\end{array}$ \\
\hline
\end{tabular}

* Enteletina zigzag $=$ Peltichia zigzag; E. sinensis $=P$. sinensis.

** Cathaysia sulcatifera $=C$. sinuata.

$\dagger$ Neowellerella $=$ Prelissorhynchia? (see discussion in systematic descriptions).

spiriferoides, new species, Chonetinella substrophomenoides (Huang), Waagenites wangina (Chao), Orthothetina regularis (Huang), and Prelissorhynchia pseudoutah (Huang). The standard section is the Yanshi section, Longyan County, Fujian Province (spot 31). The distribution of the assemblage zone usually coincides with the occurrence of fine clastic rocks (Figures 2, 3).

2. Peltichia zigzag (Huang)-Prelissorhynchia triplicatioid, new species, assemblage zone (abbreviation $P-P$ ): . The brachiopod fauna in the limestone lithofacies of the lower Changxingian is composed of Peltichia zigzag (Huang), $P$. sinensis (Huang), P. schizoloides, new species, Prelissorhynchia triplicatioid, new species, $P$. pseudoutah (Huang), Araxathyris beipeiensis, new species, Uncinunellina multicostifera, new species, Cyrolexis antearcus, new species, Squamularia formilla, new species, and Spinomarginifera kueichowensis (Huang). Three important features characterize this assemblage zone. First, the genus Peltichia of the Superfamily Enteletoidea reached its greatest abundance. Secondly, members of the order Rhynchonellida are more abundant than in brachiopod faunas of underlying and overlying beds. The third characteristic is that several relatively large-size genera, such as Dictyoclostus, Spinomarginifera, Edriosteges, and Tyloplecta, occur plentifully. The Huayingshan section, Linshui County, Sichuan Province (spot 6), is the reference locality of the assemblage zone. Limestone, marl, calcareous dolomite, and minor lithotypes are its main matrices (Figures 2,3).
3. Cathaysia sinuata Chan-Waagenites barusiensis (Davidson) assemblage zone (abbreviation $C-W$ ): This clastic lithofacies brachiopod fauna of the upper Changxingian is less diverse than the fauna in the same lithofacies of the lower Changxingian. It consists of Cathaysia sinuata Chan, Waagenites barusiensis (Davidson), Crurithyris pusilla Chan, Orthothetina regularis (Huang), and Leptodus nobilis (Waagen). The reference section is the same as that of assemblage zone 1 , but the distribution of this assemblage zone is somewhat wider than that of assemblage zone 1 (Figures 2,3).

FIGURE 2 (opposite page).-Stratigraphic sequences and brachiopod faunal ranges near the Permian-Triassic boundary in South China. The section numbers correspond to the numbers on Figure 1. (A = Araxathyris spp.; $\mathrm{Ac}=$ Acosarina spp.; $\mathrm{C}=$ Crurithyris spp.; $\mathrm{CC}=$ Cathaysia chonetinella : $\mathrm{Cs}=$ Cathaysia spp; $\mathrm{Cu}=$ Cuipingshan Formation; $\mathrm{LC}=$ lower Changxing Formation; $\mathrm{L}=$ Lingula spp.; $\mathrm{LD}=$ lower Dalong Formation; $\mathrm{LF}=$ lower Feixianguan Formation; $\mathrm{LJ}=$ lower Jinjiling Formation; $\mathrm{LL}=$ Longdongchuan Formation; LLu $=$ lower Loulou Formation; $L M=$ lower Majiaoling Formation; Lo = Longtan Formation; LP = lower Paoshui Formation; LX = lower Xikou Formation; LYa = lower Yanshi Formation; $\mathrm{M}=$ Uncinunellina multicostifera; $\mathrm{Ma}=$ Majiashan Formation; $\mathrm{O}=$ Cathaysia obicularis; $\mathrm{P}=$ Prelissorhynchia pseudoutah; $\mathrm{R}=$ Richthofenia ?; $\mathrm{S}=$ Chonetinella substrophomenoides; TLD = lower Daye Formation; $\mathrm{U}=$ Uncinunellina spp.; UC = upper Changxing Formation; UD =upper Dalong Formation; UL $=$ upper Longdongchuan Formation; UP = upper Paoshui Formation; UYa = upper Yanshi Formation; $W=$ Waagenites spp.; $W u=$ Wujiaping Formation; $\mathrm{Y}=$ Yundoutan Formation; Yi = Yinkeng Formation; $\mathrm{Z}, \mathrm{A}=$ zone of Acosarina; Z.P = zone of Prelissorhynchia; Z.R = zone of Richthofenia.) 


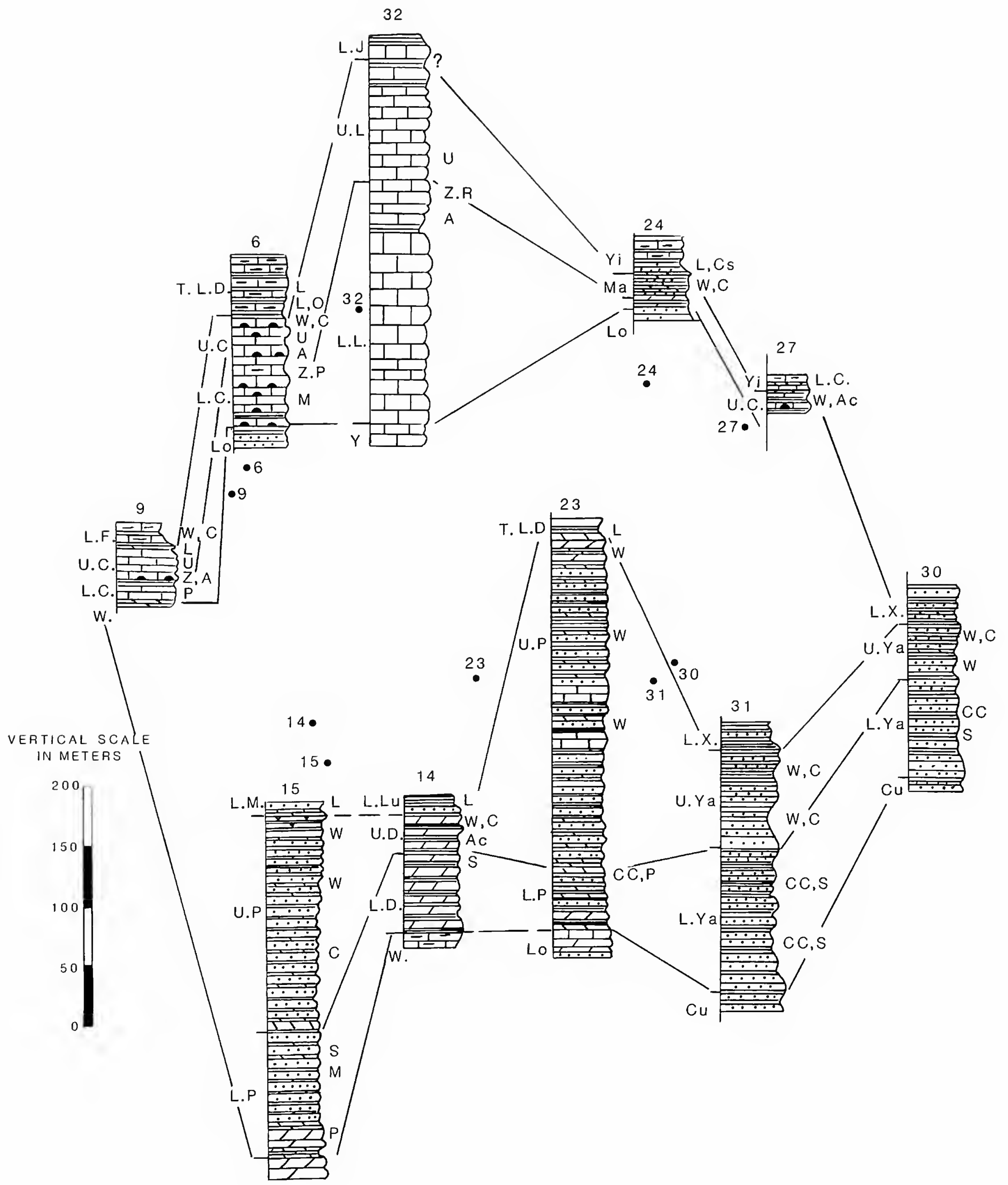

돈 LIMEstone

듸 CHERT LIMESTONE

MUDDY LIMESTONE

Silicalite

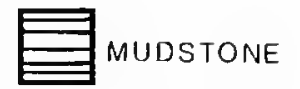

$\cdots$ sandstone

प्रिCLAY ROCK

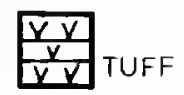




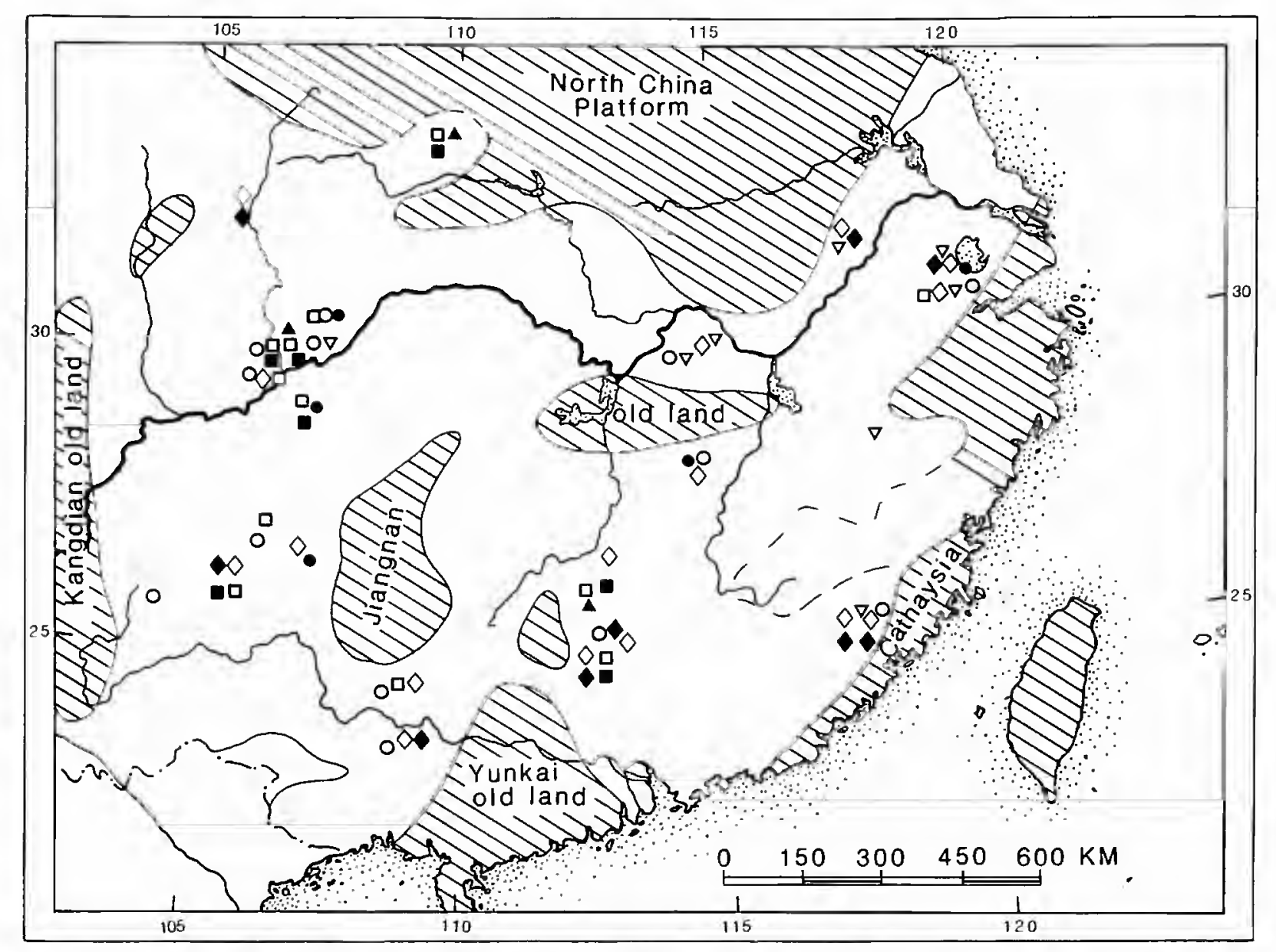

FIGURE 3.-Stratigraphic distribution of brachiopod assemblage zones and biofacies near the Permian-Triassic boundary in South China. ( Cathaysia chonetoides-Chonetella substrophomenoides assemblage zone and antibiohermal dwellers biofacies; $\bigcirc$ Cathaysia sinuata-Waagenites brusiensis assemblage and antibiohermal biofacies; - Peltichia zigzag-Prelissorhynchia triplicatioid assemblage zone and calcareous substratum biofacies: D Spirigerella discusella-Acosarina minuta assemblage zone; $\Delta$ biohermal biofacies; $\bullet$ Lingula present in top of Changxingian Formation; O Cruritlyyris pusilla-Lingula subcircularis assemblage zone; $\nabla$ Permian-type survivors biofacies.)

4. Spirigerella discusella, new species-Acosarina minuta (Abich) assemblage zone (abbreviation $S$ - $A$ ): The reference locality and distribution of this limestone lithofacies assemblage zone of the upper Changxingian is essentially the same as that of assemblage zone 2 . It contains many small-size species, for example, Acosarina minuta (Abich), A. indiça (Waagen), Crurithyris pusilla Chan. Spirigerella discusella, new species, Uncinunellina theobaldi Waagen, and Rugosomarginifera chengyaeyenensis (Huang), but it still has several medium- and large-size species, for example, Spinomarginifera alphus (Huang). Meekella langdaiensis Liao, and Perigeyerella altilosina, new species.

5. Crurithyris pusilla Chan-Lingula subcircularis Wirth assemblage zone (abbreviation $C-L$ ): The lower Griesbachian brachiopod fauna contains abundant Lingula. Crurithyris, and several Permian-type (Changxingian) survivors, such as Waagenites bartusiensis (Davidson), Cathaysia simuata Chan, $C$. orbicularis Liao, and Fusichonetes pigmaea (Liao). Many individuals of Crurithyris sp. lic scattered on the bedding surface near the bottom of the lower Daye and lower Feixianguan formations at many sections, e.g., the Shatian section, Daye City, Hubci Province (spot 17), the Liangfengya section, Zhongqing City, Sichuan Province (spot 8), and the Shandongqiao section, Quingzun County, Guizhou Province (spot 10). These brachiopods typically are small, usually only $0.5 \mathrm{~min}$, so they are difficult to identify; without magnification they could be mistaken for ostracods. Crurithyris pusilla Chan is abundant in the lower Griesbachian, but it originates in the upper Changxingian and can extend high into strata of the upper Griesbachian. Lingula ranges commonly from the top of the Changxingian, into the Lower Triassic, and thence into the Dienerian. A shell-bed occurring in the third member of the Feixianguan Formation of Liangfengya section (spot 8) has Lingula along with the bivalves Eumorphotis multiformis (Bittner), Claraia aurita (Ktauer), and C. stachei (Bittner), all of which are regarded as index fossils of the upper Griesbachian to the Smithian (Yang et al., 1987, table 2-15). Nevertheless, the truly Permian-type survivors are strictly limited to the lower Griesbachian.

\section{Relationship with Other Biozones}

No identifiable anmonoid or fusulinid fossils have been found in the lower Yanshi Formation at the Yanshi section 
(spot 31), the reference section of the $C$ - $C$ assemblage zone. In the upper Yanshi Formation, however, about $20 \mathrm{~m}$ up into the $C-C$ assemblage zone, is found the ammonoid Pseudotirolites, the index fossil to the upper Changxingian (Table 3). A rich ammonoid fauna, which has about 17 species including those in Tapashanites and Pseudostephanites, and conodont Mesogondolella subcarinata (Sweet et al.) co-occur in the $C-C$ assemblage zone in a darkish gray, medium-bedded, bituminous sparite to microsparite intercalated with siltstone, about 6 $\mathrm{m}$ thick, in the lower Changxing Formation at the Meishan section (spot 26). In that section, however, the $C$ - $C$ assemblage zone extends upward about $6 \mathrm{~m}$ where there appear conodonts of the species Mesogondolella changxingensis (Wang and Z.H. Wang), which is regarded as a representative of the upper Changxingian (Table 3). It can be secn that the top boundary of the $C-C$ asscinblage zone is higher than that of the Mesogondolella subcarinata zone. In the Paoshui section (spot 15), some important members of the $C-C$ assemblage, such as Prelissorhynchia pseudoutah (Huang) and Waagenites wongiana (Chao), are associated with the upper Changxingian ammonoids Rotodiscoceras, Pseudotirolites, and Pleuronodoceras in a light to dark gray, thin-bedded, silicified tufaceous claystone. This claystone is somewhat Icss than $1 \mathrm{~m}$ thick, and it occurs about $2 \mathrm{~m}$ above the top of the Heshan Formation (Wujiaping Stage), approximately $280 \mathrm{~m}$ below the PermianTriassic boundary. This may indicate that the top of the $C-C$ assemblage zone is higher than that of the TapashanitesShevyreviles zone (Tablc 3). In the Mcitian section, Yizhang
County, Hunan Province (spot 23), typical members of the $C$ - $C$ assemblage zone, namely, Cathaysia chonetoides (Chao), Prelissorhynchia pseudoutah (Huang), and Waagenites wongiana (Chao), along with ammonoids of the genus Tapashanites, occur in the same beds of the lower Paoshui Formation.

The $P-P$ assemblage zone is associated with the fusulinid Palaeofusulina sp. and the conodonts Hindeodus "minutus" (Ellison) (perhaps typicalis or julfensis, according to Wardlaw, pers. com. 1992) and Mesogondolella elongata (Wang and Z.H. Wang) in the Huayingshan section (spot 6). Previously we thought this conodont fauna represented the lower Changxingian (Table 3). At the Liangfengya section (spot 8) the important brachiopods Prelissorhynchia pseudoutah (Huang) and Araxathyris beipeiensis, new species, of the $P-P$ assemblage zone co-occur with the fusulinids Nanlingella simplex (Sheng and Chang) and Reichelina changhsingensis Sheng and Chang, which usually occur in the lower Changxingian (Table 3). Peltichia zigzag (Huang), the typical member of the $P-P$ assemblage zone, and conodont Mesogondolella changxingensis (Wang and Z.H. Wang) occur together in a gray, medium-bedded, cherty limestone only $1 \mathrm{~m}$ below the top of the upper Changxing Formation.

The ammonoid Pleuronodoceras and thc conodont Mesogondolella changxingensis (Wang and Z.H. Wang) (see Table 3) are associated with the brachiopods Cathaysia sinuata Chan and Waagenites barusiensis (Davidson) in a dark gray, thin-bedded, calcareous, silty mudstone in the upper Yanshi Formation at the Yanshi section (spot 31). Brachiopods of the

TABLE 3.-Zonations of ammonoids, conodonts, and fusulinids near the Permian-Triassic boundary in South China. Neogondolella $=$ Mesogondolella.

\begin{tabular}{|c|c|c|c|c|c|c|}
\hline \multirow{2}{*}{\multicolumn{2}{|c|}{$\begin{array}{c}\text { Stratigraphic } \\
\text { Units }\end{array}$}} & \multicolumn{2}{|c|}{ Ammonoid zones } & \multirow{3}{*}{$\begin{array}{l}\text { Conodont zones } \\
\text { Yang, et al. } \\
1987\end{array}$} & \multicolumn{2}{|c|}{ Fusulinid zones } \\
\hline & & \multirow{2}{*}{ Zhao et al. 1981} & \multirow{2}{*}{ Yang et al. 1987} & & \multirow{2}{*}{ Sheng 1983} & \multirow{2}{*}{ Yang et al. 1987} \\
\hline Series & Stage & & & & & \\
\hline 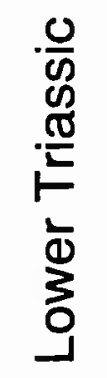 & 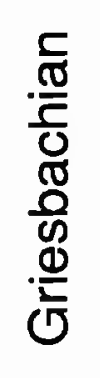 & $\begin{array}{l}\text { Otoceras, } \\
\text { Hypophiceras }\end{array}$ & Otoceras & $\begin{array}{l}\text { Hindeodus } \\
\text { parvus }\end{array}$ & & \\
\hline \multirow{2}{*}{$\begin{array}{l}\frac{c}{\mathbb{\pi}} \\
\frac{E}{0} \\
0 \\
\frac{1}{1} \\
\frac{0}{2} \\
\frac{0}{2}\end{array}$} & \multirow{2}{*}{ 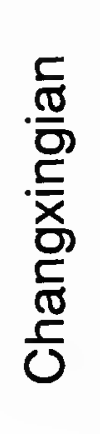 } & $\begin{array}{l}\text { Rotodiscoceras, } \\
\text { Pseudotirolites } \\
\text { Pleuronodoceras }\end{array}$ & $\begin{array}{l}\text { Rotodiscoceras } \\
\text {--- } \\
\text { Pseudotirolites }\end{array}$ & $\begin{array}{l}\text { Neogondolella } \\
\text { deflecta-- } \\
\text { Neogondolella } \\
\text { changxingensis }\end{array}$ & \multirow{2}{*}{$\begin{array}{l}\text { Palaeofusulina } \\
\text { laxa } \\
\text { Palaeofusulina } \\
\text { mutabillis } \\
\text { Reichelina } \\
\text { changhsingen- } \\
\text { sis }\end{array}$} & $\begin{array}{l}\text { Palaeofusulina } \\
\text { sinensis } \\
-- \\
\text { Reichelina } \\
\text { changhsingensis }\end{array}$ \\
\hline & & $\begin{array}{l}\text { Pseudostephanitea } \\
\text {--- } \\
\text { Tapashanites }\end{array}$ & $\begin{array}{l}\text { Tapashanites } \\
--- \\
\text { Shevyrevites }\end{array}$ & $\begin{array}{l}\text { Neogondolella } \\
\text { subcarinata-- } \\
\text { Neogondolella } \\
\text { elongata }\end{array}$ & & 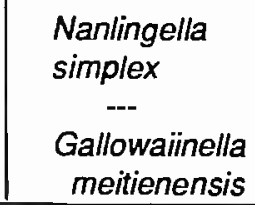 \\
\hline
\end{tabular}


$C-W$ assemblage zone, Crurithyris pusilla Chan and Orthothetina regularis (Huang), occur in a bed of light gray, medium-bedded biosparrudite about $1 \mathrm{~m}$ below the top of the Changxing Fonnation, along with the conodont Mesogondolella changxingensis (Wang and Z.H. Wang), at the Meishan section (spot 26). At the Majiashan section (spot 24) at the top of the Changxingian, Crurithyris pusilla Chan and Waagenites barusiensis (Davidson) are associated with conodont Mesogondolella deflecta (Wang and Z.H. Wang) in a bed of white-yellow claystone. The members of the $C-W$ assemblage zone, Crurithyris pusilla Chan and Cathaysia sinuata Chan, co-occur with ammonoids of the genera Pleuronodoceras and Pseudotirolites and with conodont Mesogondolella deflecta (Wang and Z.H. Wang) in the upper part of the Changxing Formation at the Shangsi section, Guangyuan County, Sichuan Province (spot 4). At the Meitien section (spot 23), the beds that contain the $C-W$ assemblage zone overlie beds that yield the ammonoid genus Tapashanites, which is associated with the $C-C$ assemblage zone.

The $S-A$ assemblage zone occurs in limestone of the upper Changxing Formation that also yields the conodonts Mesogondolella deflecta (Wang and Z.H. Wang) and M. changxingensis (Wang and Z.H. Wang) at the Huayingshan section (spot 6). Rugosomarginifera chengyaenensis (Huang), Uncinunellina theobaldi Waagen, and Spinomarginifera alphus (Huang) are associated with fusulinids of the genus Palaeofusulina and conodonts Mesogondolella deflecta (Wang and Z.H. Wang) and $M$. changxingensis (Wang and Z.H. Wang) at the Liangfengya section (spot 8). At the Longtoujiang section, Yishan County (spot 14), the brachiopods Acosarina minuta (Abich) and Uncinunellina theobaldi Waagen are mixed with brachiopods of the $C-W$ assemblage zone, Waagenites barusiensis (Davidson) and Spinomarginifera alphus (Huang), in the upper Dalong Formation and are associated with the ammonoid Pseudotirolites(?).

As mentioned above, the genera Lingula and Crurithyris have long ranges, but the species Crurithyris pusilla Chan and Lingula subcircularis Wirth occur together only in the lower Griesbachian. The Permian-type brachiopods are confined to the $C-L$ assemblage zone. In the Huayingshan section (spot 6), Crurithyris pusilla Chan is associated with Lingula subcircularis Wirth and $L$. borealis Bittner in the bottom beds of the lower Daye Formation. These bottom beds are composed of gray, thin-bedded limestone intercalated with calcareous mudstone about $1 \mathrm{~m}$ thick and also contain Acosarina minuta (Abich). This brachiopod fauna coexists with the ammonoid Ophiceras and bivalves Claraia griesbachi (Bittner) and Pseudoclaraia wangi (Patti).

Similar associations occur in many sections, such as the Xinjiacao section, Guangan County (spot 5); Yanjingxi section, Hechuan County (spot 7); Liangfengya section, Zhongqing City (spot 8); Huangzhishan section, Wuxing County (spot 27); Yading section, Zhangping County (spot 30); Baimu section, Yichun County (spot 19); and Paoshui section, Laibin County (spot 15). In several sections the Permian-type survivors are fairly abundant, occurring in the bottom beds of the lower Griesbachian. For example, the bottom bed of the Yinkeng Formation, which is bluish gray intrasparite-intramicrite intercalated dark mudstone at the Meishan section (spot 26), preserves many Permian-type brachiopods, such as, Waagenites barusiensis (Davidson), Fusichonetes pigmaea (Liao), Cathaysia sinuata Chan, C. orbicularis Liao, Acosarina sp., and Araxathyris sp., associated with the ammonoids Hypophiceras and Otoceras (by reference to J.Z. Sheng et al., 1984:143, text-fig. 6). At the bottom of the Yinkeng Formation in the Majiashan section (spot 24), Cathaysia orbicularis Liao and Waagenites barusiensis (Davidson) co-occur with Ophiceras in a bed of yellowish green, thin-bedded, hydromicaceous quartz siltstone. A similar situation can be found at the Shatian section (spot 17), Puqi section (spot 18), and Meitian section (spot 23).

Brachiopod assemblage zones correlate fairly well with ammonoid and conodont zones in the Changxingian except that the top boundary of the $C-C$ and $P-P$ assemblage zones might link to a somewhat higher horizon than the ammonoid and conodont zones in the lower Changxingian. The $C-L$ assemblage zone in the lower Griesbachian coincides roughly with the ammonoid zone Hypophiceras and ?Otoceras.

\section{Correlations within Tethys}

Places reported to have Changxingian faunas that are continuous with the lower Griesbachian occur throughout much of the extent of the Tethys. North Tibet of China, Transcaucasia of Georgia and Armenia, Kuh-e-Ali Bashi area of Iran, the Salt Range of Pakistan, and Guryul Ravine of Kashmir are well-known areas that have been reported to have Changxingian brachiopod faunas (e.g., Grant, 1970). Lately the island of Hydra, Greece, has been reported to have Changxingian brachiopods and foraminifera (Grant et al., 1991), thus providing a Changxingian link within Tethys between the Middle East and the Dolomite Alps of Italy, the westernmost marine occurrence.

A Changxingian brachiopod fauna was discovered in the Shuanghu area $\left(33.6^{\circ} \mathrm{N}, 86.8^{\circ} \mathrm{E}\right)$ of North Tibet. Jing and Sun (1981) confirmed the existence of the Changxingian brachiopod fauna and described Peltichia zigzag (Huang) and Spinomarginifera pseudosintanensis (Huang) that were collected from the Reggyorcaka Formation by Wen (in Ching, Liang, and Wen, 1979), and identified known species of other brachiopod fossils (Jing and Sun, 1981:167) including Cathaysia chonetoides (Chao), Squamularia waageni Loczy, and Leptodus sp. from the lower part of the Reggyorcaka Formation (J.Z. Sheng et al., 1984:153). The brachiopod fauna in the Tanggula-Qamdo region of North Tibet is the Peltichia sinensis-Squamularia superba assemblage, which is representative of the Changxingian in the Toba Formation (Jing and Sun, 1981:169). Those faunas undoubtedly correlate with the 
$P-P$ assemblage zone in South China; therefore, the lower part of the Reggyorcaka Formation and some part of the Toba Formation may be early Chanxingian.

In the Transcaucasia region of Armenia and Azerbaijan, the sequence of the Dzhulfa section was divided into 15 units by Stoyanow (1910; see also Ruzhentsev and Sarycheva, 1965:10; Teichert et al., 1973:364), of which units 1 to 6 contain brachiopod fossils. The fauna in unit 5 was named "zone of Productus djulfensis Stoyanow," and it also contains Orthis indica Waagen and Marginifera spinocostata (Abich). Orthotichia indica (Waagen) (= Orthis indica) was recorded from various strata of the Lower and Upper Permian in South China. Liao (1980a:145, table 1) reported Stepanoviella djulfensis (Stoyanow) (= Productus djulfensis) in the Longtan and Changxing formations in Guizhou Province. When they synthesized 5 sections (including the Dorasham section) of the Transcaucasia region, Arakelyan, Grunt, and Schevyrev (in Ruzhentsev and Sarycheva, editors, 1965:25) wrote that "horizon 3 with Bernhardites" constitutes the "Induan stage." As T.K. Zhao (1965) pointed out, most of the Induan stage actually was Permian. Rostovtsev and Azaryan (in Logan and Hills, editors, 1973:383) proposed to set up a new Permian stage, the Dorashamian, which has Araxathyris araxensis minor Grunt. "Horizon 4 with Paratirolites" possesses Enteletes dzhagrensis Sokolov, Orthotichia parva Sokolov, Orthothetina sp., Spinomarginifera pygmaea Sarycheva, Haydenella kiangsiensis (Kayser), H. minuta Sarycheva, Terebratuloidea sp., Araxathyris ogbinensis Grunt, and A. araxensis minor Grunt (Arakelyan, Grunt, and Schevyrev in Ruzhentsev and Sarycheva, editors, 1965:25). The brachiopod fauna shown by Sarycheva, Sokolov, and Grunt in their table 9 (in Ruzhentsev and Sarycheva, editors, 1965:69) consists of the same members as mentioned in horizon 4, 454 specimens collected from the Induan stage of three sections (Dorasham, Ogbin, and Prochie) of the Transcaucasia region. Teichert et al. (1973:383) pointed out that of a total of 454 specimens recorded from the Induan, 389 of those are assigned to one species, Araxathyris araxensis minor Grunt. This species was reported in the Yinkeng Formation of the Meishan section of South China (Sheng et al., 1984:143, text-figs. 6, 144). Our collections did not include this species, but the genus Araxathyris surely exists in the Changxingian of South China. Haydenella kiangsiensis (Kayser) occurs widely in the Lower to Upper Permian in South China, but it is most common in the Wujiapingian. Spinomarginifera, Enteletes, and Orthothetina occur commonly in the Changxingian; therefore, it is true that the brachiopod fauna of horizon 4 of the Induan part of the Dorashamian in the Transcaucasia region can be correlated with the Changxingian brachiopod fauna.

Teichert et al. (1973:382) reported brachiopod fossils from the Ali Bashi Formation at Kuh-e-Ali Bashi of Northwest Iran that later were identified by G.A. Cooper as Araxathyris araxensis minor Grunt and Araxathyris sp. Araxathyris araxensis minor Grunt is the main member of the Dorashamian brachiopod fauna. In the Abadeh region of Central Iran, the Surmag, Abadeh, and Hambast formations preserved abundant brachiopod fossils. The Iranian-Japanese Research Group (1981:101, table 3) concluded that unit 5 of the Abadeh Formation and unit 6 of the Hambast Formation correlate with the Wujiapingian of South China, based on fusulinids.

Unit 7 of the Hambast Formation can be compared with the Dorashamian based on ammonoids; therefore, it also can be correlated with the Changxingian. The brachiopod fauna in unit 7 of the Hambast Formation, however, contained only four species: Spinomarginifera helica (Abich), Araxathyris minor Grunt?, Notothyris aff. nucleolus (Kutorga), and Leptodus sp. (Iranian-Japanese Research Group, 1981:89, fig. 8). Nonetheless, the aspect of the brachiopod fauna in both the Ali Bashi Formation and unit 7 of the Hambast Formation is similar to the Dorashamian brachiopod fauna belonging to the age of the Changxingian, even though they are not the typical Changxingian brachiopod fauna.

Because brachiopod fossils are poorly preserved and long ranging in the topmost beds of the Chhidru Formation of the Salt Range and Trans-Indus ranges, Pakistan, the ages of the brachiopod faunas are difficult to determine. An identifiable brachiopod fauna was found preserved in the topmost bed of the white sandstone of the Chhidru Formation by Grant (1970) at two places in the Trans-Indus Khisor Range, but some of the fossils have long ranges. The Pakistan-Japanese Research Group (1981, 1985) worked in the Salt Range and Surghar Range, Pakistan, and considered that five different assemblages named $\mathrm{K}, \mathrm{Cl}$ to $\mathrm{C} 4$ can be distinguished in the Chhidru-I section (1985:254, 257, fig. 12).

The $\mathrm{K}$ assemblage correlates to the Kalabagh unit just below the $\mathrm{C}$ assemblages.

The assemblage $\mathrm{C} 4$ consists of seven species: Oldhamina decipiens (Koninck), Richthofenia lawrenciana Koninck, Spirigerella carinata Reed, Enteletes socialis Reed, Whitspakia acutangula (Waagen), Crurithyris sp., Derbyia sp., and Spinomarginifera sp. Three of the species extend from the C3 assemblage; others have long ranges that are hard to date precisely.

The brachiopod faunas of C1-C3 zones are composed of Callispirina ornata (Waagen), Cleiothyridina subexpansa (Waagen), C. grossula (Waagen), Costiferina indica (Waagen), Derbyia altestriata Waagen, $D$. grandis Waagen, $D$. hemisphaerica Waagen, D. subsinuata Reed, Enteletes socialis Reed, Hemiptychina himalayensis (Davidson), Kiangsiella pectiniformis (Davidson), Linoproductus lineatus (Waagen), Marginifera ornata Waagen, Megasteges nepalensis Waterhouse, Notothyris djoulfensis Abich, Oldhamina decipiens (Koninck), Spirigerella alata Waagen, S. carinata Reed, S. fusiformis Waagen, S. grandis (Davidson), S. minuta Waagen, Strophalosia indica Waagen, Waagenites deplenata Waagen, Waagenoconcha abichi (Waagen), and W. purdoni (Davidson). According to the opinion of the Pakistan-Japanese Research Group (1985:257, table 2), the brachiopod faunas from zones 
$\mathrm{C} 1$ to $\mathrm{C} 3$, which are referred to units 2 and 3 of the Chhidru Formation, could be correlated with the Wujiapingian to Changxingian (Changhsingian).

We conclude that the brachiopod fauna of zones $\mathrm{Cl}-\mathrm{C} 3$ of the Chhidru Formation most likely correlates with the fauna of the Wujiapingian on the basis of the following three factors. (1) Most of the zone C1-C3 species have long ranges, for example, Spirigerella derbyi (Waagen) is recorded from the Maokou to the Wujiaping Formation; Oldhamina decipiens (Koninck) and Waagenoconcha abichi (Waagen) extend from the Wujiaping to the Changxing Formation; and most species of the genera Kiangsiella and Marginifera have long ranges before the Cliangxingian in South China. (2) Several species, for example, Waageniles deplanata (Waagen) and Chonetella nasuta (Waagen), occur mainly in the Wujiapingian in South China. (3) Zones C1-C3 lack typical elements of both the Changxing brachiopod fauna and the Dorashamian fauna. Furthermore, only the fusulinid genus Codonofusiella, and not Palaeofusulina, occurs in the Chhidru Formation.

From the Kathwai Member, Mianwali Formation, Salt Range and Surghar Range. Kummel and Teichert (1966) collected several brachiopod fossils from the same beds that also had the preserved ammonoid Ophiceras connectens. These brachiopods subsequently were identified by G.A. Cooper who pointed out that they are Permian-type brachiopods that might be reworked from the underlying Chhidru Formation because of their fragmentary preservation. Several arguments against this hypothesis were enumerated by Grant (1970). The members of the brachiopod fauna in the Kathwai Member are composed of Crurithyris? extima Grant, Derbyia? sp., dielasmatid undet., Enteletes sp. 2, Linoproductus sp., Lyttonia sp., Martinia sp., Omboria sp., Orthothetina cf. O. arakeljani Sokolskaya, Orthothetina sp., Spinomarginifera sp., and Whitspakia sp. 2 (Grant, 1970:123). A lingulid was described by Rowell (1970:113-116) as Lingula sp. cf. L. borealis Bittner, and Orbiculoidea sp. was recorded by Kummel and Teichert (1970:63). Numerous specimens of Crurilhyris? extima Grant occur 5-6 feet above the base of the dolomitic unit at Khan Zaman Nala, which is well into the Triassic Ophiceras zone (Grant, 1970:144), and one specimen of Spinomarginifera sp. was collected above the lowest occurrence of the Triassic ammonoid Ophiceras (Grant, 1970:137). The situation of the brachiopod fauna in the Kathwai Member resembles the $C-L$ assemblage zone of the lower Griesbachian in South China; the common ground of both faunas is the presence of Crurithyris, Lingula, and Permian-type survivors Spinomarginifera, Enteletes, Orthothetina, Spirigerella, etc., co-occurring with Ophiceras. Typical Changxingian survivors, such as, Cathaysia, Waagenites, and Prelissorhynchia, do not occur in the Kathwai Member, and Lytronia and Linoproductus are not found in the $C$ - $L$ assemblage zone.

Waterhouse and Gupta (1983) discussed the Kathwai brachiopod fauna that was described and illustrated by Grant
(1970) who placed the fragmentary and specifically unidentifiable material in "open nomenclature." These steinkerns and fragments were assigned specious specific names by Waterhouse and Gupta (1983), illustrating a long-standing pattern of scientific mendacity that has been called to attention and documented by Talent (1989), Ahluwalia (1989), Bhatia (1989), Bassi (1989), and Janvier (1989).

According to Nakazawa et al. (1975:56, 57, table 8), brachiopods of division IV or E1 of the lowermost Khunamuh Formation at Guryul Ravine in Kashmir consist of Athyris cf. subexpansa Waagen (Nakazawa et al., 1970, text-fig. 2), Derbyia sp., Dictyoclostid?, Dielasma? sp., Linoproductus cf. lineatus (Waagen), Lissochonetes morahensis (Waagen), Marginifera himalayensis Diener, Neospirifer sp., Pustula sp., Schellwienella sp., and Waagenoconcha purdoni (Davidson). In addition, Diener (1915) described fossils Chonetes lissarensis Diener, Chonetes? aff. variolata d'Orbigny, Costiferina indica (Waagen), C. spiralis Waagen, Linoproductus cora (d'Orbigny), Spinomarginifera cf. helica (Abich), Waagenoconcha abichi (Waagen), and W. gangetica (Diener) from the same area. The fauna of division IV or E1 of the lowermost Khunamuh is similar to that of the underlying divisions of the Zewan Formation. Within that fauna, Waagenoconcha abichi, W. purdoni, Costiferina indica, and Linoproductus lineatus occur in $\mathrm{K}-\mathrm{C} 3$ assemblages of the Chhidru Formation, and Spinomarginifera helica was recorded from unit 1 of the Surmaq Formation to unit 7 of the Hambast Formation. The brachiopod fauna of division IV of the lowermost Khunamuh as a whole may be correlated with those of the Chhidru Formation; therefore, it also may be correlated with the Wujiapingian in South China. In E2 of the Khunamuh Formation, bed 52, two brachiopod species, Marginifera himalayensis Diener and Pustula sp., were reported (Nakazawa et al., 1975:59, table 9) to occur in the same bed with ammonoids Otoceras woodwardi and Glyptophiceras himalayanum. These two Permian-type brachiopod survivors are in the same stratigraphic position in the Khunamuh as other brachiopods are in the $C-L$ assemblage zone, but without species in common they can not be compared.

The Southern Alps in Italy contain a brachiopod fauna that includes Ombonia, Araxathyris, Janiceps, and Comelicania. Rare specimens of the Spiriferoidea and Dielasmatoidea occur in the upper part of the Bellerophon Formation, accompanied by ammonoids Paracellites sextensis (Diener) in the Puseria Valley near Sesto (Assereto et al., 1973:185). This fauna is older than the Dorashamian according to the view of Assereto et al. (1973:188), but Waterhouse (1976:168) considered it to be Dorashamian. The genus Araxathyris is the most abundant brachiopod in the Dorasham Formation in Transcauscasia. Ombonia was reported by Grant (1970) from the Kathwai Member, Mianwali Formation of the Surghar Range, Pakistan, and Janiceps was reported from the Longtan Formation, Guizhou Province of South China, by Liao (1980a:277, pl. 9: 
figs. 10-13). Therefore, the brachiopods seem to indicate that the fauna of the uppermost part of Bellerophon Formation correlates to the Wujiapingian and part of the Changxingian. A fauna from the Bukk Mountains of Hungary has Crurithyris, Martinia, Comelicania, Tyloplecta, and Licharewinids (Schreter, 1963). Assereto et al. (1973:187, 188) considered it to be older than the fauna of the Southern Alps.

The Marginalosia kalikotei zone of Northwest Nepal, specifically the Nisal, Nambo, and Luri Members of the Senja Formation, was named by Waterhouse (1978:136). The fauna is composed of Marginalosia kalikotei (Waterhouse), Megasteges nepalensis Waterhouse, Neospirifer ravaniformis Waterhouse, Platyconcha grandis Waterhouse, Spiriferella oblata Waterhouse, and S. rajab (Salter). The latter two species are predominant in the upper part of the zone, the Luir Sandstone Member (Waterhouse, 1978:16, 17). Waterhouse considered that the following pairs of fossils have similarities between them: Rugaria nisalensis Waterhouse of Nepal and $R$. soochowensis ( $=$ Waagenites soochowensis) (Chao) of the Lopingian in China; Marginalosia kalikotei (Waterhouse) of Nepal with $M$. planata (Waterhouse) from the Stephens Formation of New Zealand, of Vedian age; and Martiniopsis aff. inflata Waagen with the same species from the Chhidru Formation of the Salt Range. Based upon those comparisons he said, "This could imply a Djulfian (sic for Dzhulfian) or early Dorashamian (Vedian?) age" (Waterhouse, 1978:153).

Waterhouse correlated his Aperispirifer nelsonensis zone, with the Changxing? (1976, table 2, p. XVII) and the Vedian (1976:128, table 37), but he did not expound in detail. Waterhouse (1976) correlated the Stephens Formation with the Tatarian Stage, citing evidence in the South Island, New Zealand, based chiefly on the similarity of Neospirifer nelsonensis Waterhouse (=Aperispirifer nelsonensis) to Greenland shells described as "Spirifer" striato-paradoxus Toula by Dunbar (1955). The Greenland species was found with Cyclolobus, which Dunbar considered to be probably Tatarian age (Waterhouse, 1967:77). Another reason for a Late Permian age assignment was that Strophalosia planata Waterhouse (=Marginalosia planata) is close to Strophalosia gerardi W. King from the Upper Permian of Ladakh and S. blandfordi Reed from the upper Productus Limestone of the Punjab. According to Stepanov (1973), however, the Tatarian Stage includes both the Dzhulfian and the Dorashamian, and the upper Productus Limestone spans the Chhidru Formation and the Kathwai Member as shown in the table by Kummel and Teichert (1970:18, table 1). We conclude that the use of brachiopods to correlate the Aperispirifer nelsonensis zone with the Changxingian is questionable.

A brachiopod fauna almost certainly of Chanxingian age was discovered on Hydra Island, Greece (Grant et al., 1991). The Barmari Group of Late Permian age is subdivided into the Episkopi Formation below and the Miras Formation above. Abundant silicified brachiopods were collected from the
Episkopi Formation at several localities, and several new species await description. The lower part of the Episkopi contains the foraminifera Codonofusiella aff. C. schubertelloides Reitlinger, Nankingella sp., and Reichelina sp. The upper part of the formation contains Palaeofusulina, e.g., $P$. sinensis Sheng, and Colaniella, e.g., C. lapida Wang. Therefore, the brachiopod fauna in the Episkopi Formation contains constituents of both the Wujiapingian and the Changxingian. According to Nestell and Wardlaw (1987), conodonts indicate that the Episkopi is slightly older than the Changxing Formation at its type locality.

As previously mentioned, Griesbachian lingulids are distributed throughout the world, with the exception of South China and Pakistan. Species of Lingula have been reported in the following regions: the Southern Alps, Greenland, Hungary, Australia, and Iran. In the Southern Alps, Lingula tenuissima Bronn was identified from the Mazzin Member of the Werfen Formation; the fauna was called the Lingula-Neoschizodus assemblage, and it coexists with Bellerophon vaceki Bittner, which occurs with Claraia stachei (Bittner) above the bed with Otoceras woodwardi Griesbach at Shalshal Cliff (Assereto et al., 1973:188). Lingula cf. borealis Bittner occurs in the Siusi Member of the Werfen Formation with Claraia clarae (von Hauer) at the same stratigraphic position as Lingula cf. borealis (Broglio Loriga et al., 1980). In Eastern Greenland, Lingula borealis was found in the lower Ophiceras beds (Spath, 1930, 1934). In Iran, Lingula sp. was found in the lower part of the Elika Formation, and, within the dolomite, Claraia is associated with conodonts Anchignathodus typicalis Sweet and $A$. isarcicus Huckriede (Broglio Loriga et al., 1980). In the Maizuro zone of Japan, Lingula cf. borealis occurs in the strata of probable lower Scythian age (Bando, 1964). In Australia, Lingula is present in the Perth Basin, the Canning Basin, and the Bonaparte Gulf Basin; in the Perth Basin Lingula occurs about $1100 \mathrm{ft}(-330 \mathrm{~m})$ above the Permo-Triassic boundary, co-occurring with Claraia stachei (Bittner); in the Canning Basin and Bonaparte Gulf Basin Lingula is associated with the microflora Kraeuselisporites saeptatus zone, which is considered to be of Griesbachian-Dienerian age (Gorter, 1978; Tasch and Jones, 1979); in Siberia Lingula borealis Bittner was reported by Dagys (1965) from the Induan stage of Littoral Province, but it was not certain that the species occurred in the Griesbachian. In western North America, Newell and Kummel (1942) reported finding the Lingula zone in the Dinwoody Fornation above the basal siltstone in western Wyoming, and resting on the Permian Phosphoria Formation in the western part of the Owl Creek and Wind River mountains where it is overlapped by the Claraia zone in the southeastern part of the Wind River Mountains. Lingula borealis Bittner is accompanied by Ophiceras and by the brachiopods Spiriferina mansfieldi Girty and Mentzelia sp.? in the Lingula zone; Lingula borealis rarely extends into the Claraia zone. 


\section{Brachiopod Provinces and Biofacies}

The paleogeographic distribution of Permian brachiopods was discussed in detail by Nakamura et al. (1985). They defined two Late Permian provinces in the Tethyan Realm: Middle Tethyan and Gondwana Tethyan. These realms make sense from the viewpoint of the tectonics of continental massifs. Here we try to describe the Changxingian paleogeography of brachiopods, which supplements their work, and in addition, we offer a preliminary discussion of the paleogeography of brachiopods in the lower part of the Griesbachian.

The Middle Tethyan province of the Tethys Sea can be divided into two subprovinces: Cathaysia Tethyan and West Tethyan. The Middle Tethyan province of brachiopods is characterized by the occurrence of Araxathyris, Spinomarginifera, Waagenites, and Orthothetina in the Changxingian. Places with this fauna include the Southern Alps, Transcaucasia, Iran, Pakistan, Kashmir, North Tibet, and South China, essentially coinciding with the limits shown in Nakamura et al. (1985:189, 192, figs. 2, 3). Brachiopods of the Cathaysia Tethyan subprovince are mainly species of Cathaysia, Peltichia, and Prelissorhynchia, genera considered endemic by Nakanura et al. (1985:193). The subprovinces are based upon their content of characteristic genera that represent various stages of evolutionary development. The genera Costiferina, Ombonia, and Comelicania represent the West Tethyan subprovince that extends from Kashmir and Pakistan in the east to the Southern Alps in the west.

The fauna of the Senja Formation, Northwest Nepal, with its rare Strophomenida, numerous Strophalosioidea, few Productoidea, and numerous Spiriferida, belongs to a polar biome that links to the fauna of New Zealand (Waterhouse, 1978:161). Therefore, the brachiopod faunas of the Marginalosia kalikotei zone and the Aperispirifer nelsonensis zone represent Gondwana Tethys.

The brachiopod fauna of the lower Griesbachian is characterized by Lingula, Crurithyris, and a few Permian-type survivors. The former extends throughout the Tethys Sea along the margin of the Pangaea continent (Broglio Loriga et al., 1980:99, fig. 3). We shall refer to this fauna as the Circum-Pangaea brachiopod fauna.

\section{Biofacies}

Brachiopod biofacies were classified by Grant (1971) into three types, based upon study of large numbers of collections from West Texas. They are reef dwellers, antireef dwellers, and neutral or ubiquitous forms. The Huatang brachiopod fauna has "analogous phenomena" with the ecologic classification of West Texas Permian Brachiopods, as Liao and Meng (1986:73) pointed out in their analysis of the brachiopod biofacies of the Changxingian at Huatang, Chenxian County, Hunan Province. Liao $(1979,1980 \mathrm{~b})$ divided the brachiopod biofacies of the Changxingian into two types: brachiopods related to limestone and those related to silicalite. In his view, brachiopods are firmly linked to lithofacies. This paper treats brachiopods of the Changxingian in regard to biofacies, lithology, and paleogeographic position.

\section{CHANGXINGIAN BRACHIOPOD BIOFACIES}

Four brachiopod biofacies are distinguished in the Changxingian and two in the lower Griesbachian (Tables 4, 5).

ANTIBIOHERMAL BIOFACIES.-The main representatives of this facies are Waagenites, Chonetinella, and Orthothetina, all of which are characterized by a narrow coelomic cavity. Their habits were adapted to the muddy, silty, or siliceous substrate and were usually near a source of sediment adjacent to an old landmass or a site of volcanic activity. Their typical sympatriots were bivalves. This biofacies is widespread, occurring for example, at spots 30 and 31 where strata consist mainly of arenite (Yanshi Formation) and near the west margin of Cathaysia; at spots 17 and 24 where sections are an alternation of silicarite and silty mudstone or clay rock beds, and near the south margin of the North China old land; and at spots 20 and 23 where strata mainly are siliceous and clay rocks, coinciding with the basinal siliceous and clay rock facies (Sheng et al., $1985: 69$, fig. 7). It is difficult to procure brachiopods from the bioherms; only one specimen of Waagenites sp. has been reported from the Huatang fauna (Liao and Meng, 1986:73).

TABLE 4.-Brachiopod biofacies of the Changxingian stage in South China.

\begin{tabular}{|c|c|c|c|}
\hline $\begin{array}{l}\text { Antibiohermal } \\
\text { dwellers }\end{array}$ & $\begin{array}{c}\text { Calcareous } \\
\text { substratum } \\
\text { dwellers }\end{array}$ & $\begin{array}{c}\text { Biohermal } \\
\text { dwellers }\end{array}$ & $\begin{array}{l}\text { Ubiquitous } \\
\text { dwellers }\end{array}$ \\
\hline $\begin{array}{l}\text { Cathaysia } \\
\text { Chonetinella } \\
\text { Orthothetina } \\
\text { Spinomarginifera } \\
\text { Waagenites }\end{array}$ & $\begin{array}{l}\text { Araxathyris } \\
\text { Cartorhium } \\
\text { Derbyia } \\
\text { Dictyoclostus } \\
\text { Notothyris } \\
\text { Peltichia } \\
\text { Rostranteris } \\
\text { Spirigerella } \\
\text { Squamularia }\end{array}$ & $\begin{array}{l}\text { Enteletes } \\
\text { Meekella } \\
\text { Notothyris } \\
\text { Peltichia } \\
\text { Richthofenia } \\
\text { Rostranteris }\end{array}$ & $\begin{array}{l}\text { Acosarina } \\
\text { Crurithyris } \\
\text { Leptodus } \\
\text { Oldhamina } \\
\text { Prelissorhynchia }\end{array}$ \\
\hline
\end{tabular}

TABLE 5.-Brachiopod biofaces of the lower Griesbachian stage in South China.
Lingula biofacies
Permian-type survivors

Lingula
L. borealis
L. subcircularis
L. tenuissima var. sinensis
L. spp.
Crurithyris

Acosarina

Araxathyris

Chonetinella

Fanichonetes

Fusichonetes

Prelissorhynchia

Waagenites and other chonetids 
These genera are absent elsewhere in South China.

CALCAREOUS SUBSTRATUM DWELLERS.-Most brachiopods are attached by a pedicle to the substrate in all or part of their lives. Permian examples are Araxathyris, Spirigerella, Squamularia, Notothyris, Rostranteris, and Peltichia. These brachiopods lived on the platform, in relatively shallow water of low energy, attached to abandoned shells, concretions, or clastic particles. The distributive area of this biofacies includes the Sichuan and Hunan basins, such as spots 5-9.

BIOHERMAL DWELLERS.-During the last decade, several calcareous buildups of Late Permian age have been found in South China in such areas as in Lichuan County, Hubei Province; Huayingshan, Linshui County, Sichuan Province; and Huatang, Chenxian, and Longdongchuan, Zhenan County, Shaanxi Province. The Longdongchuan buildup is composed of gray or light pink, massive- to thick-bedded limestone or dolomitic limestone, bearing abundant fossils including corals, bryozoans, algae, foraminifera, and brachiopods. It is limited to a small region, laterally becoming an alternation of arenite and limestone beds. Brachiopods of this facies consist of richthofeniids, with their coralliform shells; Meekella and Perigeyerella, which have higher than normal interareas; and Araxathyris, Peltichia, Enteletes, Notothyris, and Rostranteris, whose attachments were mostly by pedicle.

Typical antibiohermal dwellers, the inarticulates and Chonetoidea, are not found in the Longdongchuan fauna. The Huatang Fauna is similar to the Longdongchuan fauna, but contains a few richthofeniids, a large group of pediculate brachiopods, and almost no chonetids or inarticulates.

UBIQUITOUS DWELLERS.- These are brachiopods that occur in various lithofacies, and they include such Changxingian examples as the small-size genera Acosarina, Crurithyris, and Prelissorhynchia, and leptodids whose shapes vary according to habitat conditions. For instance, Oldhamina is usually large and strongly inflated when preserved in limestone or bioherm; in other habitats it can be relatively small and flat.

\section{BRACHIOPOD BIOFACIES OF THE LOWER GRIESBACHIAN}

Lingula BIOFACIES.-The genus Lingula (including species $L$. subcircularis Wirth, $L$. borealis Bitner, $L$. tenuissima var. sinensis Wirth, and $L$. spp.) is spread widely in the lower Griesbachian in South China, and it commonly is accompanied by Crurithyris. At the top of the Changxingian, Lingula occurs in several sections, such as spots 5,9,12, and 19, and also in the Mashishan of Xidongtingshan Island, Wuxian County, Zhejiang Province (J.Z. Sheng et al., 1984:149, text-fig. 14). This distribution implies that a regression (sea level retreat) began as the epeiric sea became shallower in areas of central Sichuan, North Guizhou, Zhejiang, and North Jiangxi.

PERMIAN-TYPE SURVIVOR BIOFACIES.- - Several areas were found to contain Permian-type brachiopod survivors: Zhejiang (spot 26), South Anhui (spot 24), Central Hubei (spot 17), Central Sichuan (spot 6), and South Hunan (spot 23). Most of these brachiopod fossils were preserved in calcareous mudstone or marlite, many associated with bivalves.

\section{Extinction and Evolution}

Brachiopods underwent a massive extinction at the close of the Changxingian. Of the 21 superfamilies in the Changxingian, eight were extinguished completely, ending their long Paleozoic history. The extinct superfamilies are the Derbyioidea, Orthotetoidea, Aulostegoidea, Lyttonioidea, Richthofenioidea, Stenoscismatoidea, Reticularioidea, and Cryptonelloidea; Paleozoic members of the Rhynchonelloidea, Retzioidea, and Dielasmatoidea also disappeared. Only a few genera of the Enteletoidea, Chonetoidea, Productoidea, and Cyrtioidea survived into the lower Griesbachian (Tables 6, 7). Sixty-five genera and 148 species are preserved in sediments of the lower Changxingian, and 62 genera and 119 species occur in the upper Changxingian, so there is little difference between the lower and upper Changxingian in number of genera. However, the number of genera and species dropped sharply to 12 genera and 20 species in the lower Griesbachian (Tables 6, 7). The only genus known to survive of the Enteletoidea is Acosarina, a species of which was found in the Meishan section (spot 26; J.Z. Sheng et al., 1984:143, text-fig. 6) about $10 \mathrm{~cm}$ above the topmost bed of the Changxing Formation and was accompanied by Claraia wangi (Patte) and Ophiceras sp. Acosarina minuta (Abich) was identified from the Huayingshan section (spot 6) and was preserved in a calcareous mudstone about $1 \mathrm{~m}$ above the boundary between the Changxing and Daye formations in association with Claraia wangi, Eumorphotis multiformis (Bittner), and Ophiceras sp. The members of Chonetoidea and Productoidea that extend into the lower Griesbachian are the most important of the Permian-type survivors. Chonetinella cursothornia new species, accompanied by Fusichonetes pigmaea (Liao), was found in the lower Daye Formation of the Guanyinshan section (spot 18), about 20 $\mathrm{cm}$ above the topmost boundary of the Dalong Formation. Fanichonetes campigia, new species, was preserved in the lowermost part of the Xikou Formation in the Yading section (spot 30) in association with Eumorphotis multiformis. Fusichonetes pigmaea (Liao), $F$ nayongensis (Liao), Waagenites barusiensis (Davidson), Cathaysia sinuata Chan, and $C$. orbicularis Liao occur together in the lower Griesbachian, for instance, in the Meishan section (spot 26) where they are associated with Ophiceras sp. in the lower part of the Yinkeng Formation, and in the Majiashan, Shatian, and Guanyinshan sections (spots 24,17, and 18, respectively). The Chonetoidea and Productoidea disappeared after the early Griesbachian in South China.

A possible cause of the massive extinction between Paleozoic and Mesozoic was the sharp change of environment that resulted from the splitting of the supercontinent Pangaea that led to the deepening of the ocean basins and the draining of epicontinental seas. Refugia along the coastal margins of the 
TABLE 6.-Brachiopod faunas of the Changxingian and the Lower Griesbachian in South China.

\begin{tabular}{|c|c|c|c|c|c|c|c|}
\hline \multirow{2}{*}{ Fossil } & \multicolumn{2}{|c|}{ Changxingian } & \multirow{2}{*}{$\begin{array}{c}\text { Lower } \\
\text { Griesbachian }\end{array}$} & \multirow{2}{*}{ Fossil } & \multicolumn{2}{|c|}{ Changxingian } & \multirow{2}{*}{$\begin{array}{c}\text { Lower } \\
\text { Griesbachian }\end{array}$} \\
\hline & Lower & Upper & & & Lower & Upper & \\
\hline LINGULACEA Waagen, 1885 & & & $x$ & AULOSTEGACEA Muir-Wood and & & & \\
\hline Lingula actaugula Liao & & & & Cooper, 1960 & & & \\
\hline L. borealis Bittner & & & $x$ & Edriosteges subplicatilis (Frech) & & $x$ & \\
\hline L. fuyuanensis Liao & & & $x$ & E. tumitus Liao & $x$ & $x$ & \\
\hline L. subcircularis Wirth & & & $x$ & Falafer hunanensis Liao and Meng & $x$ & $x$ & \\
\hline L. tennissima var. sinensis Wirth & & & $x$ & Strophalosina chenzianensis Liao & $x$ & $x$ & \\
\hline L. sp. & & & & and Meng & & & \\
\hline ACROTRETACEA Schuchert, 1896 & & & & Tschernyschewia sinensis Chao & $x$ & & \\
\hline Orbiculoidea elegans Liao & & $x$ & & T. pseudoirginae (Huang) & $x$ & $x$ & \\
\hline O. utucleola Liao & & & & PRODUCTACEA Gray, 1840 & & & \\
\hline ENTELETACEA Waagen, 1884 & & & & Anidanthus interruptus (Huang) & $x$ & & \\
\hline Acosarina minuta (Abich) & $x$ & $x$ & & A. sinosus (Huang) & $x$ & & \\
\hline A. regularis Liao & $x$ & $x$ & $x$ & Asioproductus bellus Chan & $x$ & $x$ & \\
\hline A. strophiria sp. nov. & $x$ & & & Buxtonia sp. & $x$ & $x$ & \\
\hline Enteletes asyminatrosis sp. nov. & $x$ & $x$ & & Cathaysia chonetoides (Chao) & $x$ & $x$ & $x$ \\
\hline E. bistulcau Liao and Meng & & $x$ & & C. corculuun Liao & $x$ & $x$ & \\
\hline E. hemiplicata (Hall) & $x$ & $x$ & & C. orbicularis Liao [and C. tri- & $x$ & $x$ & $x$ \\
\hline Orthotichia iudica (Waagen) & $x$ & $x$ & & quetra Liao] & & & \\
\hline Peltichia schizoloides sp. nov. & $x$ & & & C. sinuata Chan & & $x$ & $x$ \\
\hline P. sinensis (Huang) & $x$ & $x$ & & C. spiriferoides sp. nov. & $x$ & $x$ & \\
\hline P. transversus (Huang) & $x$ & $x$ & & Chenxianoproductus changxin- & $x$ & $x$ & \\
\hline P. zigzag (Huang) & $x$ & & & gensis Liao and Meng & & & \\
\hline Schizophoria cf. tani Huang & $x$ & & & C. intercedens Liao and Meng & $x$ & $x$ & \\
\hline DERBYLACEA Stehli, 1954 & & & & C. nitens Liao and Meng & $x$ & $x$ & \\
\hline Derbyia? Inutabilis Liao & $x$ & $x$ & & Chonetella nasuta (Waagen) & $x$ & & \\
\hline D. pannuciella sp. nov. & $\hat{x}$ & $x$ & & Huatangia sulcatifera Liao and & $x$ & $x$ & \\
\hline Meekella arakeljani (Sokolskaja) & $x$ & & & Meng & & & \\
\hline M. deltoides Liao & $x$ & & & Dictyoclostus margaritatus (Man- & $x$ & $x$ & \\
\hline M. kueichowensis Huang & $x$ & & & $\begin{array}{l}\text { suy) } \\
D \text { ff tratavicus (Tschemvechew) }\end{array}$ & & & \\
\hline M. langdaiensis Liao & $x$ & & & D. cf. tratavicus (Tschernyschew) & $x$ & $x$ & \\
\hline M. sanheensis Liao and Meng & $x$ & $x$ & & Haydenella elongata Liao & $x$ & & \\
\hline Perigeyerella altilosina sp. nov. & $x$ & $x$ & & H. kiangsiensis (Kayser) & $x$ & $x$ & \\
\hline$P$. costellata Wang & & $x$ & & H. orientalis Chan & $x$ & & \\
\hline P. fastigata Liao and Meng & $x$ & $x$ & & H. qinglongensis Liao & $x$ & $x$ & \\
\hline ORTHOTETACEA Waagen. 1884 & & & & Incisius huatangensis Liao and & $x$ & $x$ & \\
\hline Orthothetina frechi (Huang) & & & & & & & \\
\hline O. regularis (Huang) & $x$ & & & "Linoproductus" kayseri (Chao) & $x$ & $x$ & \\
\hline O. ruber (Frech) & $x$ & $x$ & & Rugosornarginifera chengyaoyensis & $x$ & $x$ & \\
\hline & $x$ & $x$ & & (Huang) & & & \\
\hline ChonetaCeA Bronn, 1862 & & & & R. psuedosintanensis (Huang) & $x$ & $x$ & \\
\hline Chonetinella cursothornia sp. nov. & $x$ & $x$ & $x$ & R. sintanensis (Huang) & $x$ & $x$ & \\
\hline C. substrophoinenoides (Huang) & $x$ & & & Kurtomarginifera crassoestata $\mathrm{Xu}$ & $x$ & $x$ & \\
\hline C. volitanliopsis (Xu) & $x$ & & & K. spinatus Xu & $x$ & & \\
\hline Fanichonetes campigia sp. nov. & $x$ & $x$ & $x$ & Spinomarginifera alpia (Huang) & $x$ & $x$ & \\
\hline Fusichonetes dissulcata (Liao) & $x$ & $x$ & & S. jiaozishanensis Liao & $x$ & $x$ & \\
\hline F. nayongeusis (Liao) & $x$ & $x$ & $x$ & S. kueichowensis Liao & $x$ & $x$ & \\
\hline F. piginaea (Liao) & $x$ & $x$ & $x$ & S. lopingensis (Kayser) & $x$ & $x$ & \\
\hline Lissochouletes sp. & $x$ & $x$ & & Stepanoviella djulfensis (Stoya- & $x$ & $x$ & \\
\hline Neochonetes convexa Liao & $x$ & $x$ & & now) & & & \\
\hline N. elegans Lioa & $x$ & $x$ & & Tyloplecta yangtzeensis (Chao) & $x$ & & \\
\hline N. zhougyingensis Liao & $x$ & $x$ & & Waagenoconcha abichi (Waagen) & $x$ & $x$ & \\
\hline Waageutites banısiensis Davidson) & & & & LYTTONIACEA Waagen, 1883 & & & \\
\hline (and W. soochowensis (Chao)) & $x$ & $x$ & $x$ & Leptodus deminutus Liao & $x$ & $x$ & \\
\hline W. guizhoncusis Liao & $x$ & $x$ & & L. latiseptella Xu & $x$ & $x$ & \\
\hline W. nongiana (Chao) & $x$ & & & L. nobilis (Waagen) & $x$ & $x$ & \\
\hline
\end{tabular}


TABLE 6.-Continued.

\begin{tabular}{|c|c|c|c|c|c|c|c|}
\hline \multirow{2}{*}{ Fossil } & \multicolumn{2}{|c|}{ Changxingian } & \multirow{2}{*}{$\begin{array}{l}\text { Lower } \\
\text { Griesbachian }\end{array}$} & \multirow{2}{*}{ Fossil } & \multicolumn{2}{|c|}{ Chang xingian } & \multirow{2}{*}{$\begin{array}{c}\text { Lower } \\
\text { Griesbachian }\end{array}$} \\
\hline & Lower & Upper & & & Lower & Upper & \\
\hline L. richthofeni Kayser & $x$ & $x$ & & SPIRIFERININACEA Davidson, 1884 & & & \\
\hline L. tenus (Waagen) & $x$ & $x$ & & Callispirina? rotundella sp. nov. & $x$ & & \\
\hline Oldhamina anshnensis Huang & $x$ & $x$ & & Paraspiriferina alpha (Huang) & $x$ & $x$ & $x$ \\
\hline O. decipiensis (Koninck) & $x$ & $x$ & & Spiriferellina elegantula Liao & $x$ & $x$ & \\
\hline O. decipiensis var. regularis Huang & $x$ & $x$ & & S. fastigata (Schellwien) & $x$ & $x$ & \\
\hline O. grandis Huang & $x$ & & & ATHYRIDIDACEA M'Coy, 1844 & & & \\
\hline $\begin{array}{l}\text { O. minor Chan } \\
\text { O. subdecipiensis Liao }\end{array}$ & $x$ & $x$ & & Araxathyris cf. araxensis Grunt & $x$ & $x$ & \\
\hline O. subsquamosa Liao & $\begin{array}{l}x \\
x\end{array}$ & & & A. Iminura Grunt & $x$ & $x$ & $x$ \\
\hline RICHTHOFENIACEA Waagen, 1885 & & & & A. beipeiensis sp. nov. & $x$ & $x$ & \\
\hline Richthofenia ans/mensis Liao & $x$ & & & $\begin{array}{l}\text { A. subpentangulata sp. nov. } \\
\text { Rectambitus bisulcalus (Liao) }\end{array}$ & $\begin{array}{l}x \\
x\end{array}$ & $\begin{array}{l}x \\
x\end{array}$ & \\
\hline$R . ?$ sinensis Liao & $x$ & & & Spirigerella discusella sp. nov. & $x$ & $x$ & \\
\hline R. tilita Liao and Meng & $x$ & $x$ & & S. guizhouensis (Liao) & $x$ & $x$ & \\
\hline $\begin{array}{l}\text { Richthofeniacea gen. and sp. un- } \\
\text { determinable }\end{array}$ & $x$ & $x$ & & $\begin{array}{l}\text { S. ovaloides sp. nov. } \\
\text { S. shuizhutangensis (Chan) }\end{array}$ & $\begin{array}{l}\times \\
\times\end{array}$ & & \\
\hline $\begin{array}{l}\text { WELLERELL.ACEA Xu and Liu, } \\
1983\end{array}$ & & & & $\begin{array}{l}\text { Tongzithyris ans/mensis Liao } \\
\text { T. extensa Liao }\end{array}$ & $\begin{array}{l}x \\
x\end{array}$ & $x$ & \\
\hline Prelissorhynchia triplicata Liao & $x$ & & & T. sichuanensis $\mathrm{Xu}$ & $x$ & & \\
\hline P. Iriplicatioid sp. nov. & $x$ & $x$ & & RETICULARIACEA Waagen, 1883 & & & \\
\hline P. pseudoutah (Huang) & $\times$ & $x$ & $x$ & Martiuia abrupta Liao and Meng & $x$ & $x$ & \\
\hline Uncinunellina theobaldi Waagen & $x$ & $x$ & & M. acutirostris Liao & $x$ & $x$ & \\
\hline U. jabiensis (Waagen) & $x$ & & & M. chidruensis Waagen & $x$ & $\times$ & \\
\hline U. Inulticostifera sp. nov. & $x$ & & & M. lopingensis Chao & $x$ & & \\
\hline U. timorensis (Beyrich) & $x$ & & & M. squainularioides Huang & $x$ & $x$ & \\
\hline $\begin{array}{l}\text { RHYNCHONELLACEA Gray, } 1848 \\
\text { Terebratuloidea davidsoni Waagen }\end{array}$ & $x$ & & & $\begin{array}{l}\text { M. tongmugiaoensis Liao and } \\
\text { Meng }\end{array}$ & $x$ & $x$ & \\
\hline T. depressa Waagen & $x$ & $x$ & & $\begin{array}{l}\text { Phricodothyris guizhouensis Liao } \\
\text { Squamularia elegantula (Waagen) }\end{array}$ & $\begin{array}{l}x \\
x\end{array}$ & $\begin{array}{l}x \\
\times\end{array}$ & \\
\hline $\begin{array}{l}\text { STENOSCISMATACEA Oehlert, } \\
1887(1883)\end{array}$ & & & & $\begin{array}{l}\text { S. formilla sp. nov. } \\
\text { S. grandis Chao }\end{array}$ & $\begin{array}{l}x \\
\times\end{array}$ & $x$ & \\
\hline Cyrolexis antearcuss sp. nov. & $\begin{array}{l}x \\
x\end{array}$ & $\begin{array}{l}x \\
x\end{array}$ & & S. inaequilateralia (Gemmellaro) & $x$ & & \\
\hline $\begin{array}{l}\text { C. beccojectus sp. nov. } \\
\text { Hybosienoscisina bainbusoidea } \\
\text { Liao and Meng }\end{array}$ & $\begin{array}{l}x \\
\times\end{array}$ & $\begin{array}{l}x \\
x\end{array}$ & & $\begin{array}{l}\text { RETZIACEA Waagen, } 1883 \\
\text { Hustedia indica (Waagen) }\end{array}$ & $x$ & $x$ & \\
\hline SPIRIFERACEA King, 1846 & & & & H. orbicostata sp. nov. & $x$ & $x$ & \\
\hline Cartorhium twifurcifer sp. nov. & $x$ & $x$ & & M. remola (Eicnwald) & $x$ & & \\
\hline C. xikonensis sp. nov. & $x$ & $x$ & & DIELASMATACEA Schuchen, 1914 & & & \\
\hline Eliva? depressa Liao and Meng & $x$ & $x$ & & $\begin{array}{l}\text { Delasma aculangulu!n Waagen } \\
\text { Oinglongia tumita Liao and Meng }\end{array}$ & $\begin{array}{l}x \\
x\end{array}$ & $x$ & \\
\hline $\begin{array}{l}\text { Semibrachythyrina anshunensis } \\
\quad \text { Liao }\end{array}$ & $x$ & $x$ & & Q. zhougyingensis Liao & $x$ & $x$ & \\
\hline CYRTIACEA Fredericks, 1924 & & & & CRYPTONELLACEA Thomson, 1926 & & & \\
\hline $\begin{array}{l}\text { Ambocoelia pianoconvex (Shu- } \\
\text { mard) }\end{array}$ & & $x$ & & $\begin{array}{l}\text { Nolothyris bifoldes sp. nov. } \\
\text { N.? dapaichongellsis Liao and } \\
\text { Meng }\end{array}$ & $\begin{array}{l}x \\
x\end{array}$ & $\begin{array}{l}x \\
x\end{array}$ & \\
\hline Crurithyris flabelliformis Liao & & $x$ & $x$ & $N$. djoulfensis ( $\mathrm{Bbich})$ & $x$ & $x$ & \\
\hline $\begin{array}{l}\text { C. longa Liao } \\
\text { C. pusilla Chan }\end{array}$ & $x$ & $\begin{array}{c}x \\
x\end{array}$ & $x$ & N. warthi Waagen & $x$ & & \\
\hline $\begin{array}{l}\text { C. pusilia Chan } \\
\text { C. speciosa Wang }\end{array}$ & $x$ & $\hat{x}$ & $x$ & Rostranteris prychiventria sp. nov. & $x$ & $x$ & \\
\hline C. subspeciosa Liao & $x$ & $x$ & & & & & \\
\hline Eolaballa pristina Liao and Meng & $x$ & $x$ & & & & & \\
\hline
\end{tabular}


TABLE 7.-Genus distribution of superfamilies from the Changxingian to the lower Griesbachian, showing massive extinction after the Changxingian. Each line represents a genus.

Lingulacea
Acrotretacea
Enteletacea
Derbyiacea
Orthotetacea
Chonetacea
Aulostegacea

Productacea

Lyttoniacea
Richthofeniacea
Wellerellacea
Rhyrchonellacea
Stenascismatacea
Spiriferacea
Cyrtiacea
Spiriferininacea
Athyrididacea
Reticulariacea
Retziacea
Dielasmatacea
Cryptonellacea

Lingulacea
Acrotretacea Enteletacea

Derbyiacea rthotetacea

Aulostegacea

Richthofeniacea

Wellerellacea

Rhychonellacea

Spiriferacea

Cyrtiacea
Athyrididacea
Reticulariacea
Cryptonellacea

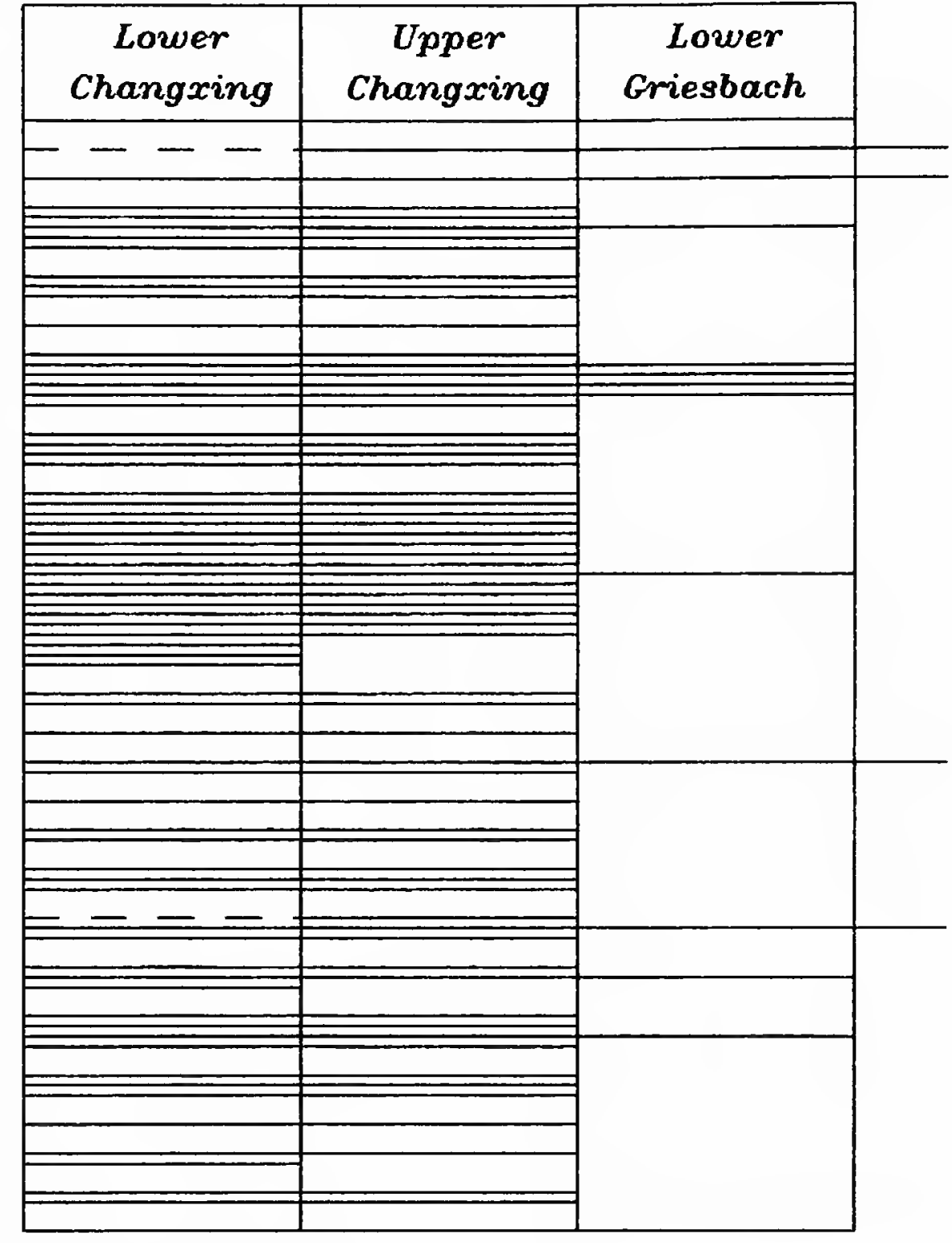

vast supercontinent allowed some marine organisms, including brachiopods, to survive the crisis.

Genera Prelissorhynchia of the Wellerelloidea, Paraspiriferina(?) of the Spiriferinoidea, and Araxathyris(?) of the Athyrididoidea represent harbingers of Mesozoic brachiopods rather than Permian-type survivors. These genera occur in the lower Griesbachian and are accompanied by other Permiantype brachiopods and the mollusks Ophiceras and Claraia, for example, in the Meishan section (spot 26). They vanished after the lower Griesbachian, giving way to the Mesozoic brachiopods.

Some fragments of brachiopods, including Spiriferina sp. and Retzioidea, were found by Wuhan geology students in the Fourth Member (Dienerian) of the Daye Formation, a thick bed of gray sparite near the top of the Xiushan, Daye County. Spirigerella sp. of the Athyrididoidea was recorded in the Kathwai Member of the Mianwali Formation, Pakistan, and Spiriferina mansfieldi Girty of the Spiriferinoidea was described in West-central North America, in the Lingula zone (Newell and Kummel, 1942). In the Littoral Province of Siberia, Fletcherina margaritovi (Bittner) of the Order Terebra- tulida, Spiriferina aff. mansfieldi Girty, and poorly preserved rhynchonellids (probably Piarorhynchia? triassica Girty) were reported in the upper Induan (Dagys, 1965:160). Fletcherina margaritovi also was found in the Olenekian Stage of Manguslaka, Siberia. Brachiopods of the Lower Triassic, however, are extremely rare. What direction had brachiopod evolution been taking from the lower Griesbachian to Middle Triassic? Why were so few brachiopods preserved in the Lower Triassic? These puzzles remain to be solved.

\section{Conclusions}

The clastic and limestone lithofacies of the Changxingian have different brachiopod assemblages (Table 2) that basically coincide with ammonoid, conodont, and fusulinid zones of the Changxingian in South China (Table 3). The Dorashamian brachiopod fauna of Transcaucasia correlates with the Changxingian fauna; the brachiopod faunas of the Ali Bashi Formation, North-West Iran; and with unit 7 of the Hambast Formation, Central Iran. The upper part of the Bellerophon Formation, Southern Alps; the upper Episkopi Formation; and 
the Miras Formation of Hydra, Greece, resemble the Dorashamian fauna, and so they also are correlated with the Changxing.

Two brachiopod subprovinces can be recognized in the Middle Tethyan province of the Changxingian; namely, the Cathaysian Tethys and the West Tethys. Four biofacies exist in the Cathaysian subprovince of the Changxingian.

The Crurithyris pusilla-Lingula subcircularis assemblage zone of the lower Griesbachian in South China closely resembles the brachiopod fauna of the Kathwai Member in Pakistan.

The Lingula fauna of the Griesbachian is distributed throughout the world, which suggests that the margins of the Pangaean supercontinent had stabilized by that time.

Massive extinction of brachiopod faunas occurred after the Changxingian, and only a few Permian-type brachiopods survived into the Lower Griesbachian. All but the few forerunners of Mesozoic brachiopods vanished completely after the early Griesbachian.

\section{Systematic Listing}

Order ORTHIDA Schuchert and Cooper, 1932

Superfamily RHIPIDOMELLOIDEA Schuchert, 1913

Family SCHIZOPHORIIDAE Schuchert and LeVene, 1929

Genus Acosarina Cooper and Grant, 1969 Acosarina strophiria sp. nov.

Superfamily ENTELETOIDEA Waagen, 1884

Family ENTELETIDAE Waagen, 1884

Genus Enteletes Fischer de Waldheim, 1825 Enteletes asymmatrosis sp. nov.

Genus Peltichia Jing and Liao, 1981 Peltichia schizoloides sp. nov.

Order STROPHOMENIDA Opik, 1934

Suborder ORTHOTETIDINA Waagen, 1884

Superfamily DERBYIOIDEA Stehli, 1954

Family DERBYIDAE Stehli, 1954

Subfamily DERBYINAE Stehli, 1954

Genus Derbyia Waagen, 1884 Derbyia pannuciella sp. nov.

Family MEEKELLIDAE Stehli, 1954

Genus Meekella White and St. John, 1867 Meekella langdaiensis Liao, 1980

Superfamily ORTHOTETOIDEA Waagen, 1884

Family ORTHOTETIDAE Waagen, 1884

Genus Perigeyerella Wang, 1955

Perigeyerella altilosina sp. nov.

Suborder CHONETIDINA Muir-Wood, 1955

Superfamily CHONETOIDEA Bronn, 1862

Family RUGOSOCHONETIDAE Muir-Wood, 1962

Subfamily CHONETINELLINAE Muir-Wood, 1962

Genus Chonetinella Ramsbottom, 1952

Chonetinella cursothornia sp. nov.

Chonetinella volitanliopsis Xu, 1987
Subfamily RUGosochonETINAE Muir-Wood, 1962

Fanichonetes gen. nov.

Fanichonetes campigia sp. nov.

Suborder PRODUCTIDINA Waagen, 1883

Superfamily PRODUCTOIDEA Gray, 1840

Family CHONETELLIDAE Likharev, 1960

Genus Cathaysia Ching, 1966

Cathaysia sinata Chan, 1979

Cathaysia spiriferoides sp. nov.

Cathaysia obicularis Liao, 1980

Superfamily RICHTHOFENIOIDEA Waagen, 1885

Richthofeniid, genus and species undetermined

Order RHYNCHONELLIDA Kuhn, 1949

Superfamily WELLERELLOIDEA Xu and Liu, 1983

Family WELLERELLIDAE Likharev, 1956

Genus Uncinunellina Grabau, 1932

Uncinunellina multicostifera sp. nov.

Family PONTISIIDAE Cooper and Grant, 1976

Subfamily LISSORHYNCHIINAE Xu and Liu, 1983

Prelissorhynchia gen. nov.

Prelissorhynchia pseudoutah (Huang, 1933)

Prelissorhynchia triplicatioid sp. nov.

Superfamily STENOSCISMATOIDEA Oehlert, 1887 (1883)

Family ATRIBONIIDAE Grant, 1965

Subfamily ATRIBONIINAE Grant, 1965

Genus Cyrolexis Grant, 1965

Cyrolexis antearcus sp. nov.

Cyrolexis beccojectus sp. nov.

Order SPIRIFERIDA Waagen, 1883

Suborder SPIRIFERIDINA Waagen, 1883

Superfamily SPIRIFEROIDEA King, 1846

Family SPIRIFERIDAE King, 1846

Subfamily NEOSPIRIFERINAE Waterhouse, 1968

Genus Cartorhium Cooper and Grant, 1976

Cartorhium xikouensis sp. nov.

Cartorhium twifurcifer sp. nov.

Superfamily CYRTIOIDEA Frederiks, 1924

Family AMBOCOELIIDAE George, 1931

Genus Crurithyris George, 1931

Crurithyris pusilla Chan, 1979

Suborder SPIRIFERINIDINA Cooper and Grant, 1976

Superfamily SPIRIFERINOIDEA Davidson, 1884

Family PARASPIRIFERINIDAE Cooper and Grant, 1976

Genus Paraspiriferina Reed, 1944

Paraspiriferina alpha (Huang, 1933)

Genus Callispirina Cooper and Muir-Wood, 1951

Callispirina? rotundella sp. nov.

Suborder ATHYRIDIDINA Boucot, Johnson, and Staton, 1964

Superfamily ATHYRIDIDOIDEA McCoy, 1844

Family ATHYRIDIDAE McCoy, 1844

Subfamily SPIRIGERELLINAE Grunt, 1965

Genus Araxathyris Grunt, 1965

Araxathyris beipeiensis sp. nov.

Araxathyris subpentangulata sp. nov. 
Rectambitus gen. nov.

Rectambitus bisulcatus (Liao, 1980), new combination

Genus Spirigerella Waagen, 1883

Spirigerella discusella sp. nov.

Spirigerella guizhouensis (Liao, 1980), new combination

Spirigerella ovaloides sp. nov.

Spirigerella shuizhutangensis (Chan, 1979), new combination

Genus Tongzithyris Ching, Liao, and Fang, 1974

Tongzithyris sichuanensis $\mathrm{Xu}, 1987$

Superfamily RETICULARIOIDEA Waagen, 1883

Family ELYTHIDAE Frederiks, 1924

Genus Squamularia Gemmellaro, 1899

Squamularia formilla sp. nov.

Suborder RETZIIDINA Boucot, Johnson, and Staton, 1964

Superfamily RETZIOIDEA Waagen, 1883

Family RETZIIIDAE Waagen, 1883

Genus Hustedia Hall and Clarke, 1893

Hustedia orbicostata sp. nov.

Order TEREBRATULIDA Waagen, 1883

Superfamily CRYPTONELLOIDEA Thomson, 1926

Family NOTOTHYRIDIDAE Likharev, 1960

Genus Rostranteris Gemmellaro, 1899

Rostranteris ptychiventria sp. nov.

Genus Notothyris Waagen, 1882

Notothyris bifoldes sp. nov.

Order ORTHIDA Schuchert and Cooper, 1932

Superfamily RHIPIDOMELLOIDEA Schuchert, 1913

Family SCHIZOPHORIIDAE Schuchert and LeVene, 1929

Genus Acosarina Cooper and Grant, 1969

Acosarina strophiria sp. nov.

FiguRES $4,5(1-17,19,20)$

Small for genus, subequally biconvex; outline transversely subelliptical except protruding beaks, width greater than length, greatest width somewhat anterior to midlength; hinge line short, about equal $101 / 2$ width; slightly asymmetrical, having beaks bent slightly rightward, sides rounded; anterior commissure with slightly ventrad wave and slightly emarginate; surface multicostellate, $15-17$ costellae in $3 \mathrm{~mm}$, grow laminac irregularly spaced, most frequent at anterior margin.

Pedicle valve flatly convex, umbonal region more convex and slightly curved forward in lateral profile; anterior profile faintly convex with gentle slopes; beak small, slightly incurved, interarea triangular, slightly curved; delthyrium proportionately large, opened. Brachial valve somewhat strongly convex, posterior $1 / 2$ moderately curved and anterior $1 / 2$ gently inclined in lateral profile; anterior profile slightly

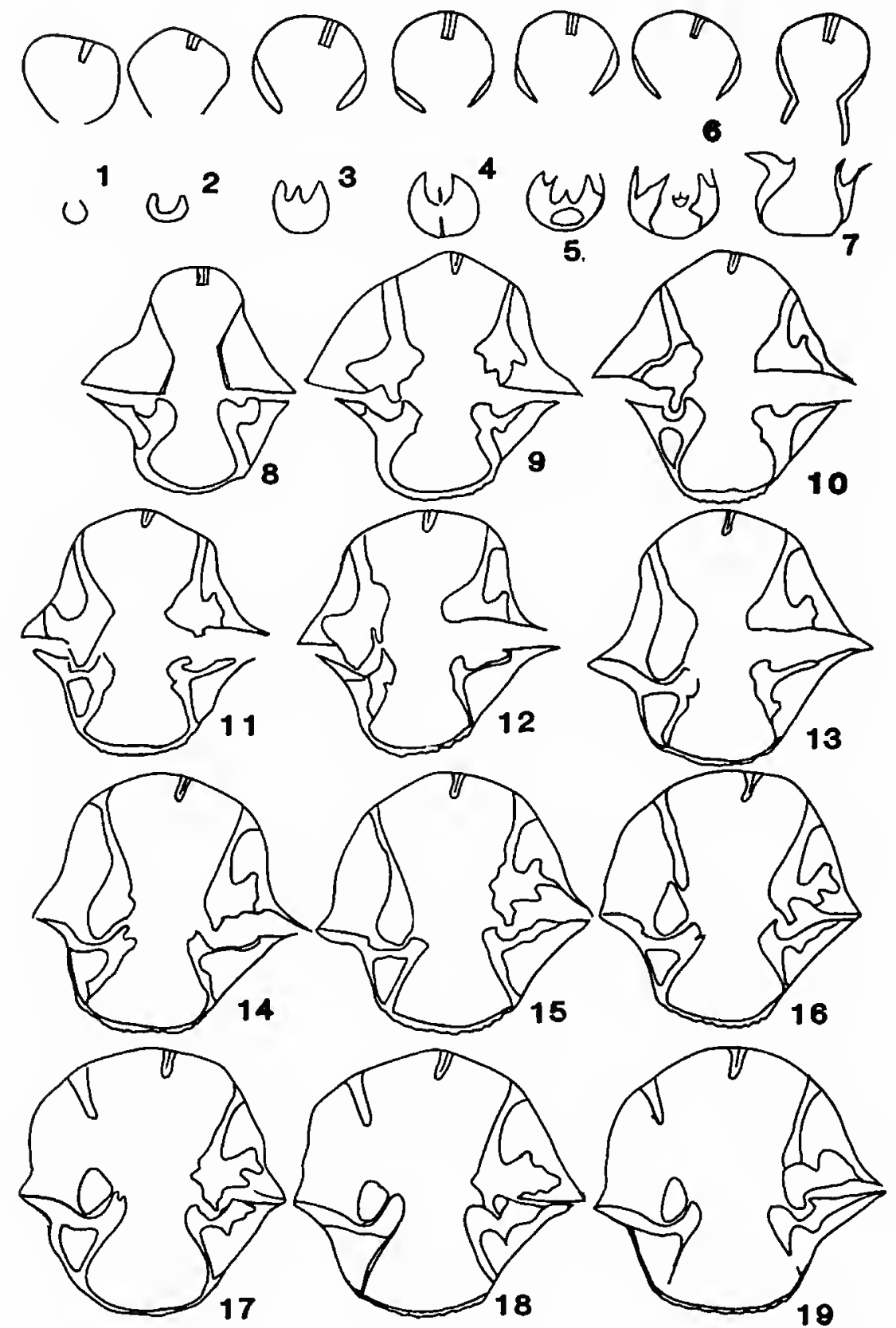

FIGURE 4.- Serial sections of Acosarina strophiria, new species, illustrating the interior features.

flattened, weakly ditched at medium region, sides relatively steep; beak strongly incurved; interarea very low with perceptible notothyrium, opened; sulcus narrow and shallow, originating somewhat anterior to beak.

Pedicle valve interior with proportionately large, cone-shape teeth having large but shallow fosettes; dental plates thick, steeply tilted, fused into shell wall in umbonal cavity, flaring anteriorly, extending about $1 / 4$ valve length; median septum low but rather long, extending near anterior edge of shell. Brachial valve interior with small cardinal process, triangular, single-edge myophragm; hinge sockets wide and shallow; fulcral plates short, hanging under socket bottoms, not reaching to shell floor, inner-socket ridges stout; brachiophore supports thick, widely flaring; posterior pair of adductor-muscle scars elongately elliptical, anterior pair of adductor-muscle scars subtriangular; median ridge long, extending more than $1 / 2$ length.

HOLOTYPE.-USNM 455970. 


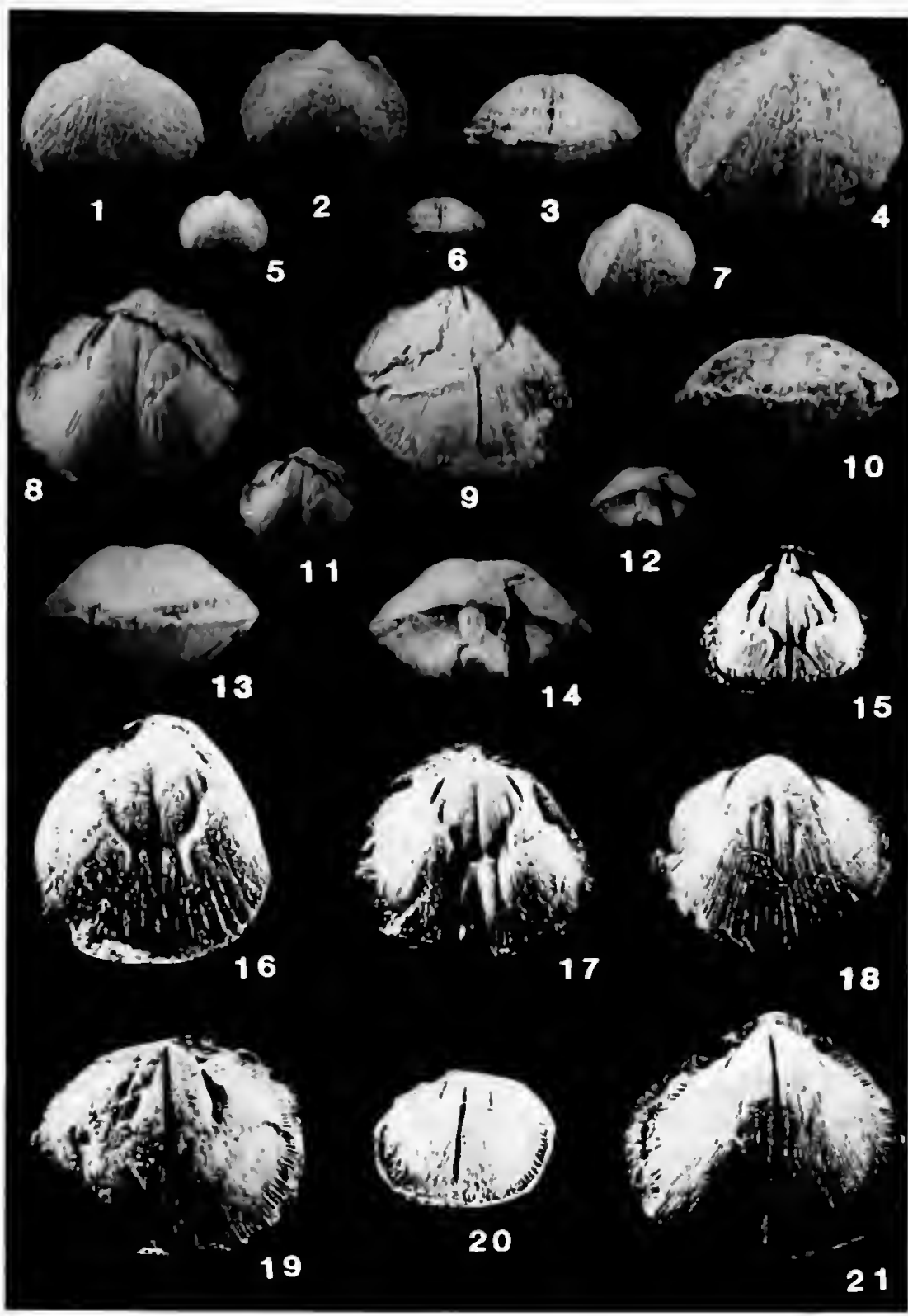

FIGURE 5.-Acosarina. 1-17, 19, 20, Acosarina strophiria, new species: 1-3, ventral, dorsal, and anterior views $(x 2) ; 5,6$, dorsal and anterior views $(x 1)$, from section 27. USNM 455970, holotype. 4, 10, dorsal and anterior views $(\times 2)$ : 7, dorsal view $(\times 1)$, from section 8, USNM 455969. 8, 9, 13, and 14 , dorsal, ventral, anterior, and posterior view's $(\times 2) ; 11,12$, dorsal and posterior views $(\times 1)$, from section 6, USNM 455968, paratype. 15, dorsal interior impress $(\times 2)$, from section 27, USNM 455971. 16, dorsal interior $(\times 2)$, USNM 455972: 17, dorsal interior $(\times 2), 455973$, both from section 10.19 . ventral interior impress $(\times 2)$, from section 10. USNM 455974. 20, ventral interior impress ( $\times 2)$, from section 8. USNM 455975. 18, 21, A. circular Xu: 18. dorsal view $(\times 2)$, USNM 455976; 21, ventral view ( $\times 2)$, USNM 455977, both from section 23. (Reduced to $951 / 2 \%$ for publication.)

MEASUREMENTS ( $\mathrm{mm})$.-

$\begin{array}{cccccc}\text { Pedicle } & \begin{array}{c}\text { Brachial } \\ \text { valie } \\ \text { valve } \\ \text { length }\end{array} & \begin{array}{l}\text { length } \\ \text { USNM }\end{array} & \text { Widh } & \begin{array}{c}\text { Hinge } \\ \text { nidth }\end{array} & \begin{array}{l}\text { Thick- } \\ \text { ness }\end{array} \\ 455968 & 9.5 & 9.6 & 11.5 & 5.3 & 6.4 \\ 455969 & 9.1 & 9.2 & 11.2 & 4.8 & 6.2 \\ 455970 & 7.2 & 6.9 & 9.0 & 4.3 & 4.8\end{array}$

STRATIGRAPHIC OCCURRENCES ANI) LOCALiTIES.Changxing Formation: Huangzhishan section, Wuxing County,
Zhejiang Province; Beipei section, Zhongqing City and Huayingshan section, Linshui County, Sichuan Province.

DIAGNOSIS.-Small, transversely subelliptical, sulcus on brachial valve and long median septum in pedicle valve.

COMPARISON.-This new species closely resembles $A$. dorsisulcata Cooper and Grant (1969:2, pl. 5: figs. 19-23; 1976b:2621, pl. 667: figs. 1-26, pl. 673: figs. 1-6) in that both species are characterized by small size and have the sulcus on the dorsal valve. The Texas species has somewhat strong costellae and a relatively short median septum in the pedicle valve. The present new species has a special feature in being slightly asymmetrical; these features allow the species to be readily distinguished from each other. Acosarina regularis Liao (1980a:253, pl. 1: figs. 29-34) has a long median septum comparable to the new species, but it is large and has a fold on the brachial valve and a sulcus on the pedicle valve. (It is possible that Liao's species may be not a species of Acosarina.) It is similar to $A$. circular Xu (in Yang et al., 1987:216, 217, pl. 13: figs. $12,13,17$ ) in its small size, long median septum in the pedicle valve, and median ridge in brachial valve; it differs in the latter's having a subcircular outline and no sulcus.

ETYMOLOGY.-From the Greek, strophos, meaning turn or twist.

\section{Superfamily ENTELETOIDEA Waagen, 1884 \\ Family ENTELETIDAE Waagen, 1884}

\section{Genus Enteletes Fischer de Waldheim, 1825}

\section{Enteletes asymmatrosis sp. nov.}

\section{FIGURE 6(1-8)}

Medium size for genus, subequally biconvex with brachial valve deep and large; outline transversely subelliptical, asymmetrically crooked, maximum width somewhat anterior to midlength; lateral profile subcircular; hinge line short with blunt hinge extremities; anterior commissure uniplicate and strongly serrated. emarginate at middle; lateral commissure straight or slightly curved; surface with plications, smoothly rounded, originating from umbonal area, having a smooth lateral area, no plicae; costellate evenly spaced.

Pedicle valve convex with maximum curvature at posterior $1 / 2$ in lateral profile; anterior profile strongly serrate at median area, smoothly tilted at sides; sulcus narrow with angular floor, beginning from umbonal area; each side with 4 plications; beak strongly incurved, partly covering interarea and delthyrium; interarea small, curved; delthyrium large. Brachial valve strongly and evenly convex, maximum inflation at midvalve in lateral profile; anterior profile slightly flattened at median part, steeply sloped on each side; fold narrow with smoothly rounded crest; each side with 4 plications; beak strongly incurved, slightly over hinge line; interarea relatively large but partly covered by beak. Interior features unknown. 


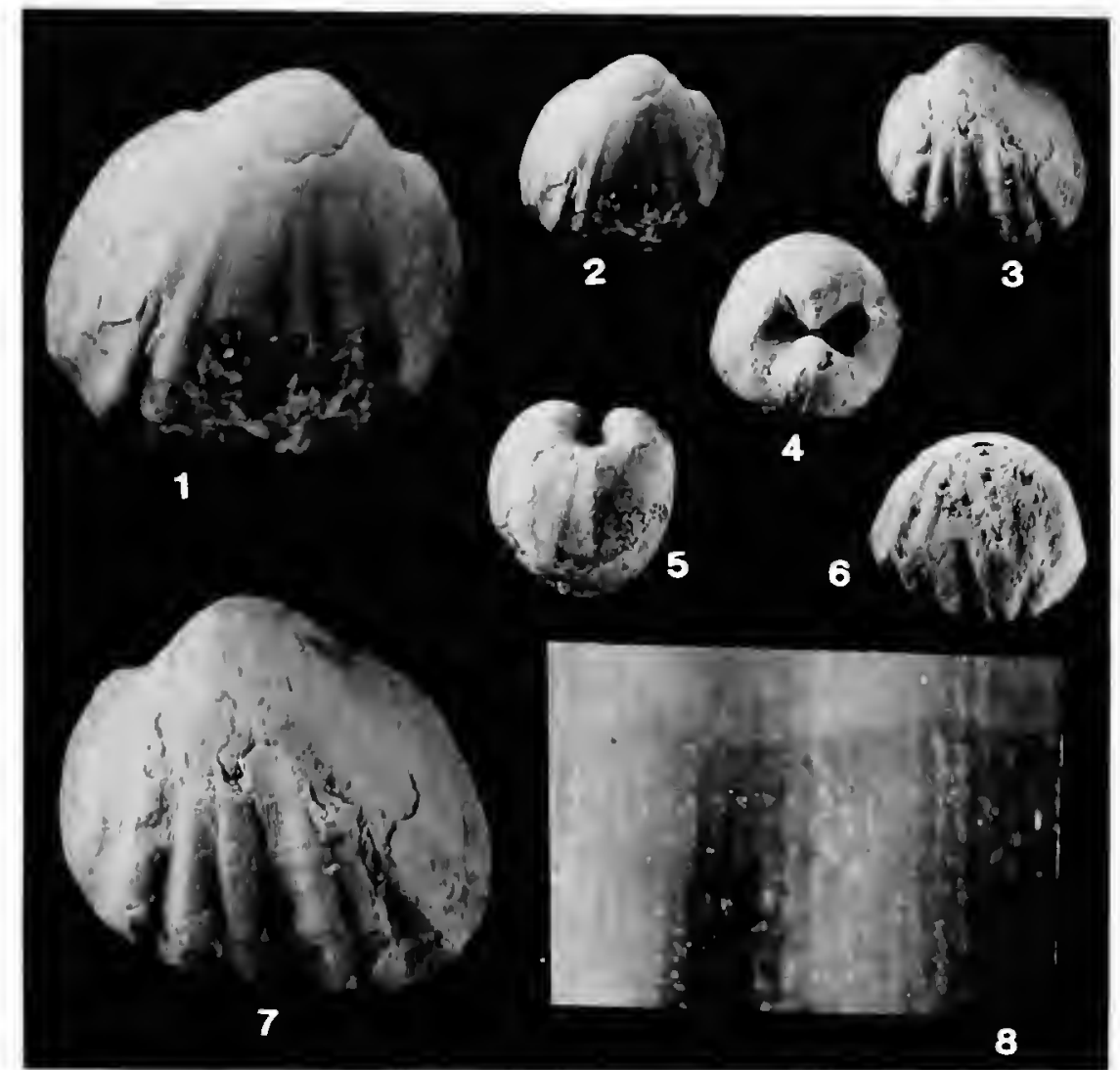

FIGURE 6. Enteletes asymmatrosis, new species, from section 32, USNM 455978, holotype: 1,2 , ventral views $(x 2, x 1) ; 3,7$, dorsal views $(x 1, \times 2) ; 4$, posterior view $(x 1) ; 5$, lateral view $(x 1) ; 6$, anterior view $(x 1) ; 8$, a part of shell showing fine costellae $(\times 20.8)$. (Reduced to $95 \frac{1}{2} \%$ for publication.)

HOLOTYPE.-USNM 455978.

MEASUREMENTS (mm).-

$\begin{array}{cccccc} & \begin{array}{c}\text { Pedicle } \\ \text { valve }\end{array} & \begin{array}{c}\text { Brachial } \\ \text { valve }\end{array} & & \text { Hinge } & \text { Thick. } \\ \text { USNM } & \text { length } & \text { length } & \text { Width } & \text { width } & \text { ness } \\ 455978 & 17.0 & 17.6 & 18.5 & 11.8 & 16.5\end{array}$

STRATIGRAPHIC OCCURRENCE AND LOCALITY.-Longdongchuan Formation: Xikou section, Zhenan County, Shaanxi Province.

DIAGNOSIS.-Medium-size Enteletes with globular outline, strongly incurved beaks, small interarea, and narrow fold and sulcus.

COMPARISON.-The new species is closely similar to Enteletes tschernyschewi Diener (1897:67, 68, pl. 5: figs. 7-10; Wang et al., 1964:149, 150, pl. 19: figs. 22-26) in its shape of shell, narrow sulcus, and number of plications; it differs in its relatively longer hinge line, smoothly rounded plications, and large sinooth lateral area. Another Himalayan species, E. waageni Gemmellaro (Diener, 1903:28, 29; Wang, 1955b:162, pl. 95: figs. 19, 21-24) is comparable to the new species in the relatively high interarea and strongly incurved beaks, but the former has sharply angular plications and fold, strongly convex shell, and well-developed growth lines. Enteletes leonardensis R.E. King (Cooper and Grant, 1976b:2634, 2635, pl. 680: figs. 1-13, pl. 683: figs. 1-48, pl. 684: figs. 16-20) has a narrow sulcus, rounded plications reaching to umbonal region, and its fold and sulcus are without much more relief than its lateral plications. These features are analogous to those of the new species, differing in that the former has a larger maximum size, a high degree of convexity, and a short brachial interarea. The new species is readily distinguishable from E. plummeri R.E. King (Cooper and Grant, 1976b:2636-2638, pl. 680: figs. 14-38, pl. 682: figs. 1-68) because King's species has sharp plications, a relatively high fold, and nearly equal valves.

ETYMOLOGY.-From the Greek, asymmetros, meaning different.

\section{Genus Peltichia Jing and Liao, 1981}

FIGURES 7,8

Medium to large size; unequally biconvex with strongly inflated brachial valve; subpentagonal in outline; anterior commissure paraplicate, lateral commissure serrate; surface completely capillate and only weak plications near anterior margin or completely obsolete.

Pedicle valve moderately convex; beak pointed and slightly or strongly incurved; hinge line short; cardinal area relatively small with proportionately large open delthyrium; fold low, limited by lateral furrows. Brachial valve strongly inflated; beak strongly incurved; sulcus shallow, bounded by rounded plications.

Pedicle valve interior with sturdy dental plates and low median septum. Brachial valve interior with rod-like, stout brachiophores, supported by strong crural plates divergently attached to floor; callus filling between crural plates, forming shovel-like pseudocruralium; median ridge low, covered by callus; 2 pairs of muscle scars, posterior pair elliptical, attached on callus platform, anterior pair slightly depressed.

COMPARISON.-Peltichia is similar to Enteletina in most external and internal features, but the latter has conspicuous plications on the lateral surfaces and no pseudocruralium in the brachial valve. It resembles Parenteletes in having a sulcus on the brachial valve and a fold on the pedicle valve; it differs in that the latter has strong lateral plications and a V-shape camera

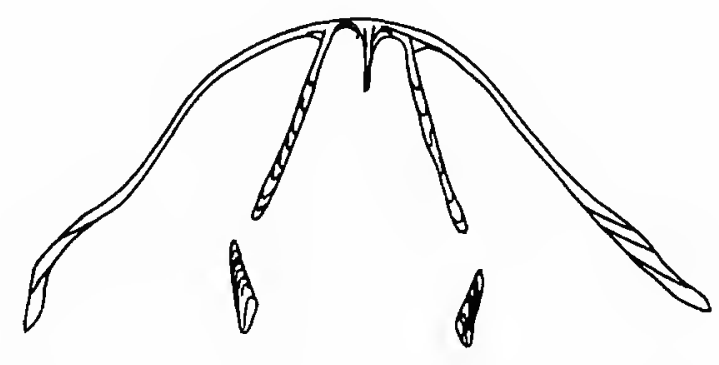

FIGURE 7.-A ventral section of Peltichia sinensis (Huang) showing dental plates, teeth, and median septum. 


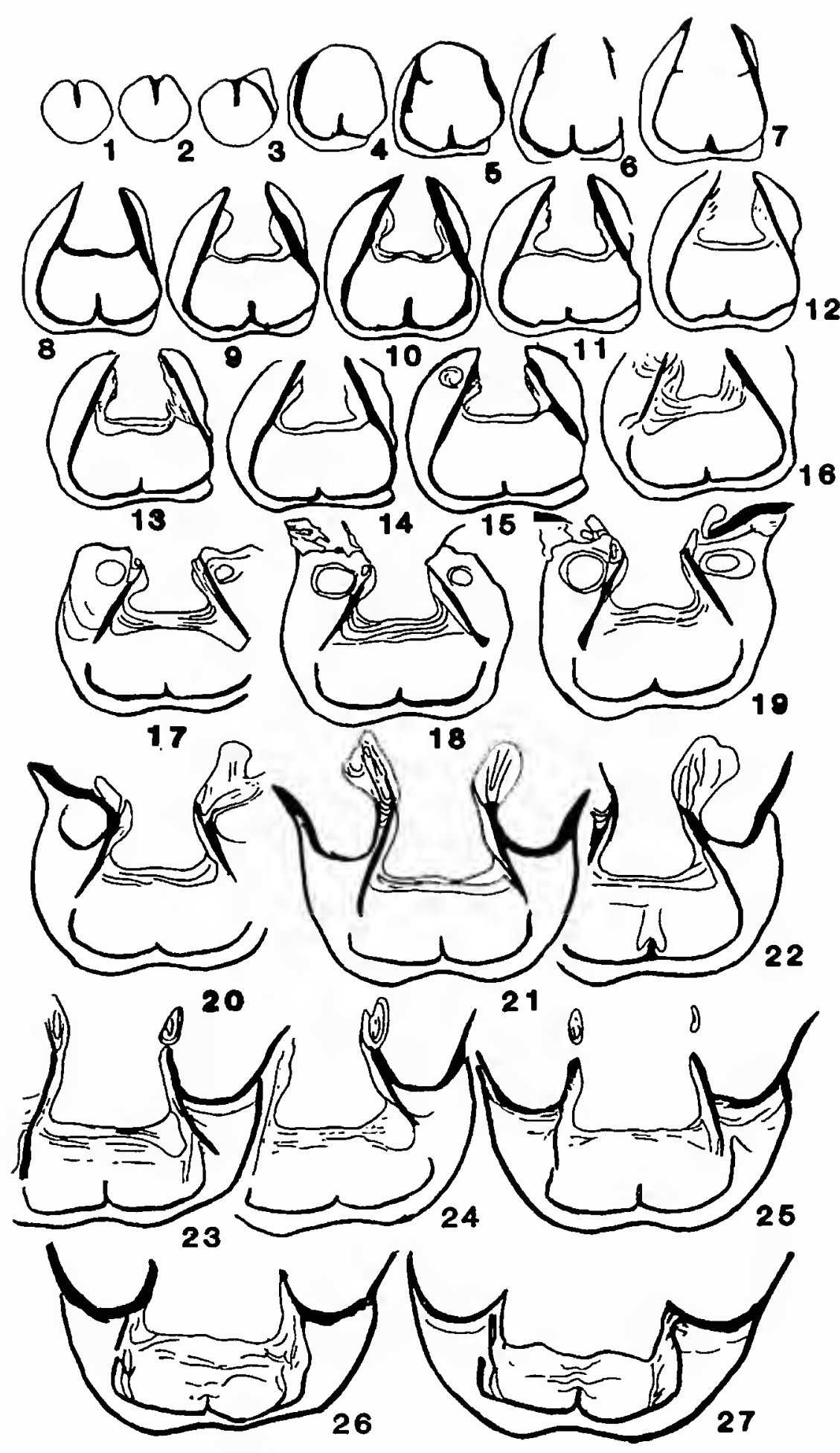

FIGURE 8.-Serial sections of the brachial valve of Peltichia sinensis (Huang) showing interior features.

under the median septum in the pedicle valve.

DISCUSSION.-Specimens of the type species Peltichia sinensis mut. zigzag were ascribed to the genus $P$ arenteletes by Huang (1933:13) and were later regarded as Enteletina by many authors (e.g., Wang et al., 1964:151, 152); but no interior structures were revealed in detail by them.

Schuchert and Cooper (1931:247) characterized the genus Enteletina as: "Externally like Parenteletes but internally like Enteletes. Equal to Waagen's 'dorsosinuates' of Enteletes." Their subsequent monograph (Schuchert and Cooper, 1932:148) states that "the dental plates are not strongly divergent and there is a crested median septum which does not have the peculiar V-shaped camera so characteristic of Parenteletes." The type species of Enteletina, E. latesinuatus, was shown to have strong plications and triple plates consisting of dental plates and a median septum in the pedicle valve, which are almost parallel to each other (Schuchert and Cooper, 1932, pl. 24: figs. 17, 19, 20).

Cooper and Grant (1976b:2626-2628) pointed out that the dental plates among species of Enteletes may be parallel or inclined, the shell may be thickened to form a narrowly divided platform between the crural plates or not thickened, and a median ridge may exist in the brachial valve or is absent, as special variations within the genus Enteletes. This statement suggests that other Enteletae may have the same range of special variations. The triple plates of the pedicle valve appear to be parallel on the exfoliated shell or internal molds of Peltichia sinensis, but the dental plates diverge ventrally and the median septum is relatively low (Figure 7). The callus between the crural plates unites an undivided platform called the pseudocruralium in the brachial valve. If the thickened shell and callus are peeled, the appearance is that of an elongated or flattened muscle-scar track at the umbonal region. These features occur consistently in the genus, so it is reasonable to discriminate Peltichia sinensis from Enteletina.

Liao's (1979:207) first use of the name Peltichia contained no description, and furthermore, he continued to assign the specimens to Enteletina (Liao, 1980:253). When Jing and Liao (in Jing and Sun, 1981:129, 130, text-fig. 2, pl. 1: figs. 3, 4) described species of this genus they illustrated internal features by serial sections of specimens from Xizang (Tibet). These are completely in concordance with specimens from South China.

TYPE SPECIES.-Parenteletes sinensis mut. zigzag Huang, 1933:10-13, pl. 2: figs. 7a-c.

SPECIES OF THE GENUS.-The five species from the Changxing Formation of South China are as follows: Peltichia sinensis (Huang) (Figure 9(11-16, 20, 23, 27), Figure 10(1-15)); P. zizag (Huang), which usually occurs in the lower part of the Changxing Formation (Figure 9(25, 26, 28-31)); $P$. transversus (Huang) (Figure 9(17, 18, 21, 22, 24)); $P$. kwangtungensis (Chan) (in Hou et al., 1979:62, 63, pl. 10: figs. 1,3); and $P$. schizoloides, new species (Figure 9(1-10)).

\section{Peltichia schizoloides sp. nov.}

\section{FIGURE 9(1-10)}

Small for genus, unequally biconvex; outline subpentagonal to subcircular, transverse, widest at midlength; anterior commissure plicate, not serrate at lateral commissure; surface with completely capillate and irregularly spaced growth laminae.

Pedicle valve weakly convex, lateral profile evenly and shallowly bowed, anterior profile somewhat flattened at midline, gently inclined at lateral slopes; beak small, pointed, slightly incurved at tip; hinge area small, delthyrium open, proportionately big; fold low, beginning from near midvalve, lateral furrows shallow. Brachial valve strongly inflated, lateral 


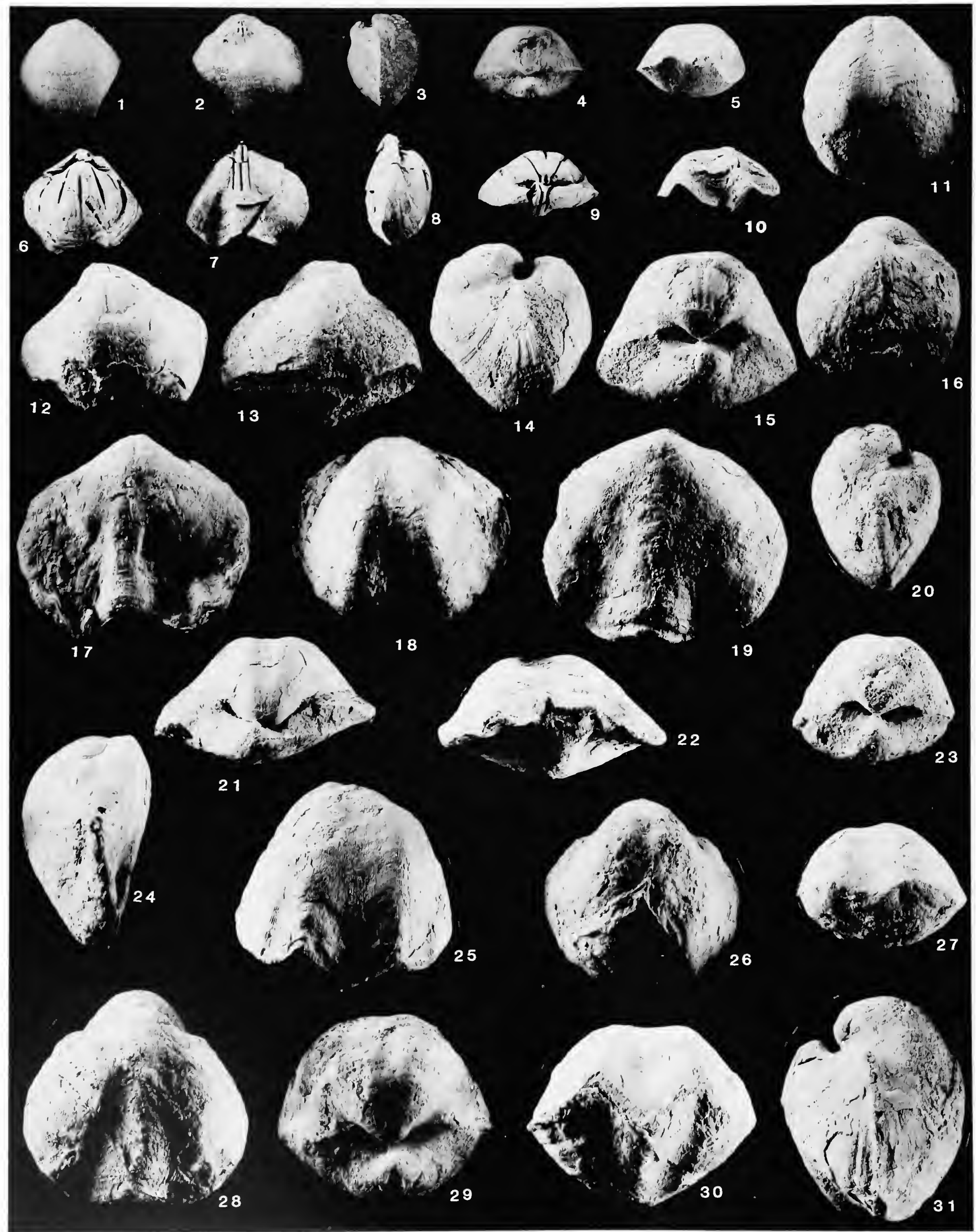


FIGURE 9 (opposite page).-Peltichia Jing and Liao. 1-10, Pellichia schizoloides. new species: $1-5$, dorsal, ventral, lateral, posterior, and anterior views $(\times 1)$, from section 6, USNM 455980, holotype; 6-10, dorsal, ventral, lateral, posterior, and anterior views $(\times 1)$, from section 27 , USNM 455979 , paratype. 11-16, 20, 23, 27, Peltichia sinensis (Huang): 11, 16, 20, 23, and 27, dorsal, ventral, lateral, posterior, and anterior views $(\times 1)$, USNM 455981; 12-15, dorsal, ventral, lateral, and posterior views $(\times 1)$, USNM 455982, bot $h$ from section 10. 17-19,21, 22, and 24, Peltichia transversus (Huang): 17 , $18,21,22$, and 24 , ventral, dorsal, posterior, anterior, and lateral views $(\times 1)$, from section 6, USNM 455984; 19, dorsal view $(\times 1)$, from section 10, USNM 455985. 25, 26, 28-31, Peltichia zigzag (Huang): dorsal, dorsal-posterior, ventral, posterior, anterior, and lateral views $(\times 1)$, from section 9, USNM 455986.

profile strongly curved at umbonal region, sloped to anterior margin; beak small, pointed, and strongly incurved; sulcus wide and shallow, originating slightly posterior to midvalve.

Pedicle valve interior with triple plates extending to near midvalve. Brachial valve interior with strong crural plates, diverging forward, they and median ridge extending to midvalve; cardinal process a single sinall protuberance at posterior view and bilobate in anterior view.

HOLOTYPE.-USNM 455980.

MEASUREMENTS (mm).-

\begin{tabular}{|c|c|c|c|c|c|c|}
\hline \multirow[b]{2}{*}{ USNM } & \multicolumn{2}{|c|}{ Pedicle valve } & \multicolumn{2}{|c|}{ Brachial valve } & \multirow[b]{2}{*}{ Width } & \\
\hline & Length & $\begin{array}{l}\text { Curved } \\
\text { length }\end{array}$ & Length & $\begin{array}{l}\text { Curved } \\
\text { length }\end{array}$ & & $\begin{array}{c}\text { Thick- } \\
\text { ness }\end{array}$ \\
\hline $\begin{array}{l}455979 \\
455980\end{array}$ & $\begin{array}{l}17.9 \\
16.7\end{array}$ & $\begin{array}{l}20.5 \\
19.3\end{array}$ & $\begin{array}{l}18.6 \\
19.3\end{array}$ & $\begin{array}{l}26.1 \\
24.7\end{array}$ & $\begin{array}{l}20.8 ? \\
19.5\end{array}$ & \\
\hline
\end{tabular}

STRATIGRA PIIC OCCURRENCE AND LOCALITIES.-Changxing Formation: Huayingshan section, Linshui County, Sichuan Province and Huangzhishan section. Wuxing County, Zhejiang Province.

DIAGNOSIS.-Small with shallow and broad sulcus on brachial valve, low fold on pedicle valve, not serrate at lateral commissure.

COMPARISON.-Peltichia schizoloides, new species, can be recognized easily by its small size, markedly transverse and broad sulcus, and smooth lateral commissure. Among other species of the genus, it most closely resembles $P$. transversus (Huang). The latter is usually larger than the new species and has a relatively narrow sulcus that begins near the beak and is acutely angled and serrate at the lateral commissure. Peltichia kwangtungensis (Chan) is the largest species of the genus and is convex-plane in lateral profile; therefore, it can be discriminated from $P$. schizoloides, even though they are analogous in their smooth lateral commissure and broad sulcus. Peltichia sinensis (Figure 10) and $P$. zigzag are large in average size, markedly elongated, and have proportionately narrow sulcus and serrate lateral commissure, so they are distinguishable readily from the new species.

ETYMOLOGY.-From the Greek, schizos, meaning a chip (small).

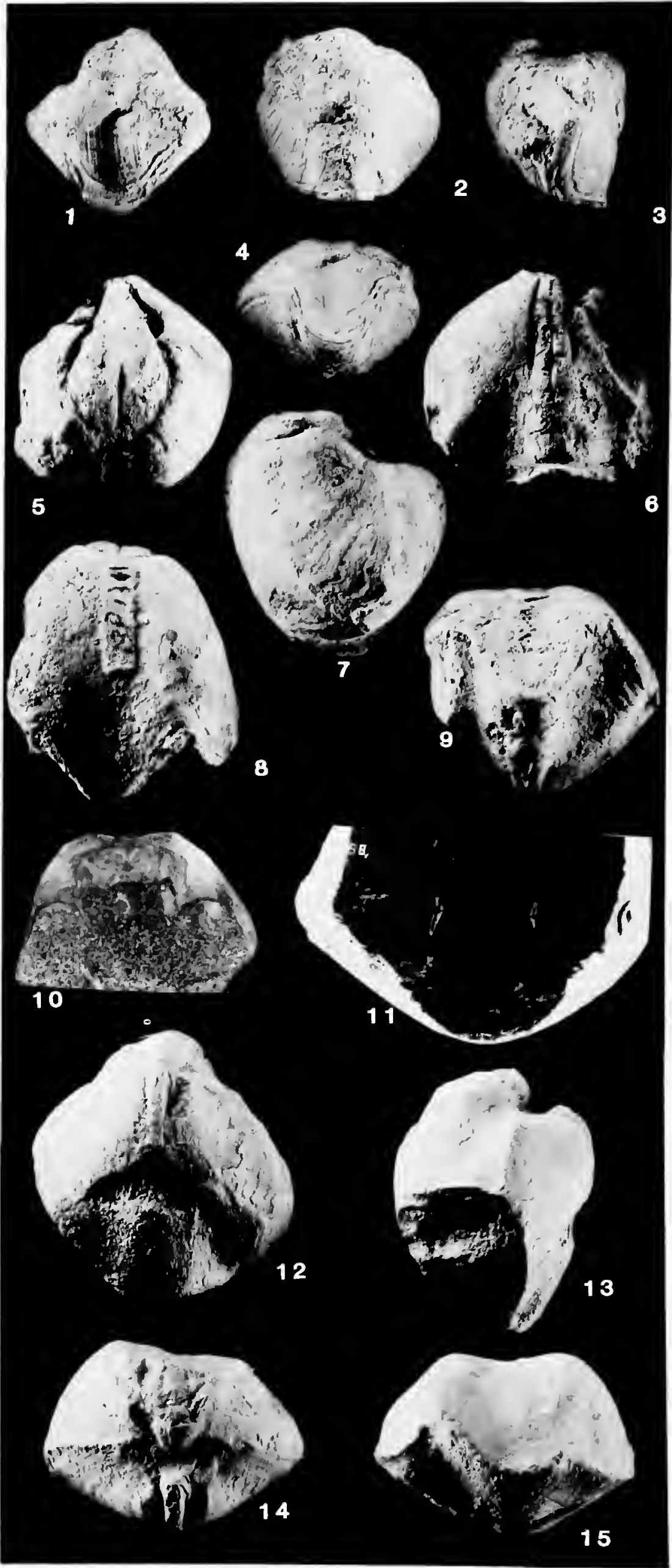

FIGURE 10.-Peltichia sinensis (Huang): 1-4, dorsal, ventral, lateral, and anterior views $(\times 1)$, from section 8, USNM 455987; 5-9, dorsal-posterior, ventral, lateral, dorsal, and anterior views $(\times 1)$, from section 8, USNM 455988; 10. 11, thin sections showing dorsal and ventral intemal structures, from sections 10 and 8, USNM 455983,455989, respectively; 12-15, ventral, lateral, posterior, and anterior views $(\times 1)$, from section 32, USNM 455990. (Reduced to $95^{1} / 2 \%$ for publication.) 
Order Strophomenida Opik, 1934

Suborder OrThotetidina Waagen, 1884

Superfamily DeRBYIOIDEA Stehli, 1954

Family DERBYIDAE Stehli, 1954

Subfamily Derby INAE Stehli, 1954

Genus Derbyia Waagen, 1884

Derbyia pannuciella sp. nov.

FIGURE 11(1-5)

Medium size for genus, moderately biconvex; subrhomboidal in outline, asymmetrical; hinge line straight, about $3 / 5$ as wide as midwidth, slightly auriculate at hinge extremities; anterior commissure slightly sulcate; surface with moderately strong costellae, somewhat alternating in strength, number on either valve $10-13$ in $5 \mathrm{~mm}$, increasing by bifurcation; plications intersecting costellae, extending directions of plicae differently at each side of shell, forming rhombic reticulation, reflected in interior surface of both valves.

Pedicle valve moderately convex; interarea low, nearly flat, apsacline, ornamented by very fine lines perpendicular to hinge; pseudodeltidium narrowly arched, perideltidium wide, reaching about $1 / 3$ width of hinge. Brachial valve somewhat less strongly inflated; sulcus shallow, beginning near beak, gradually widening forward.

Pedicle valve interior with high median septum. Other interior features unknown.

HOLOTYPE.-USNM 455991.

MEASUREMENTS (mm).-

$\begin{array}{cccccccc} & \begin{array}{c}\text { Pedicle } \\ \text { valve }\end{array} & \begin{array}{c}\text { Brachial } \\ \text { valve }\end{array} & \begin{array}{c}\text { Maximum } \\ \text { width }\end{array} & \begin{array}{c}\text { Hinge } \\ \text { line }\end{array} & \begin{array}{c}\text { Inter- } \\ \text { area }\end{array} & \text { Thick- } \\ \text { USNM } & \text { length } & \text { length } & \text { length } & \text { width } & \text { width } & \text { ness } \\ 455991 & 36.0 & 37.4 & 42.7 & 24.6 & 8.0 ? & 22.2\end{array}$

STRATIGRAPHIC OCCURRENCE AND LOCALITY.-Changxing Formation: Huangzhishan section, Wuxing County, Zhejiang Province.

DIAGNOSIS.-Medium size, moderately biconvex, shallow sulcus on brachial valve, and tilted extending plications forming rhombic reticulate "braided" ornament pattern.

COMPARISON.-Derbyia pannuciella, new species, is similar to $D$. pannucia Cooper and Grant (1974:308-311, pl. 68: figs. 1-3, pl. 83: figs. $1-12$, pl. 84: figs. 1-8, pl. 85: figs. 1-7, pl. 86: figs. 1-11) in its braided plication pattern, narrow pseudodeltidium, and wide interarea; but the latter is very large, with a nearly semicircular outline, rather wide perideltidium, and no sulcus. It resembles $D$. cincinnata Cooper and Grant (1974:294-297, pl. 79: figs. 1-21, pl. 80: figs. 1-17) in its strongly braided, bumpy ornament; it differs in that the West Texas species has a wide pseudodeltidium, catacline interarea, and no sulcus. Actually, the braided, bumpy omament is more

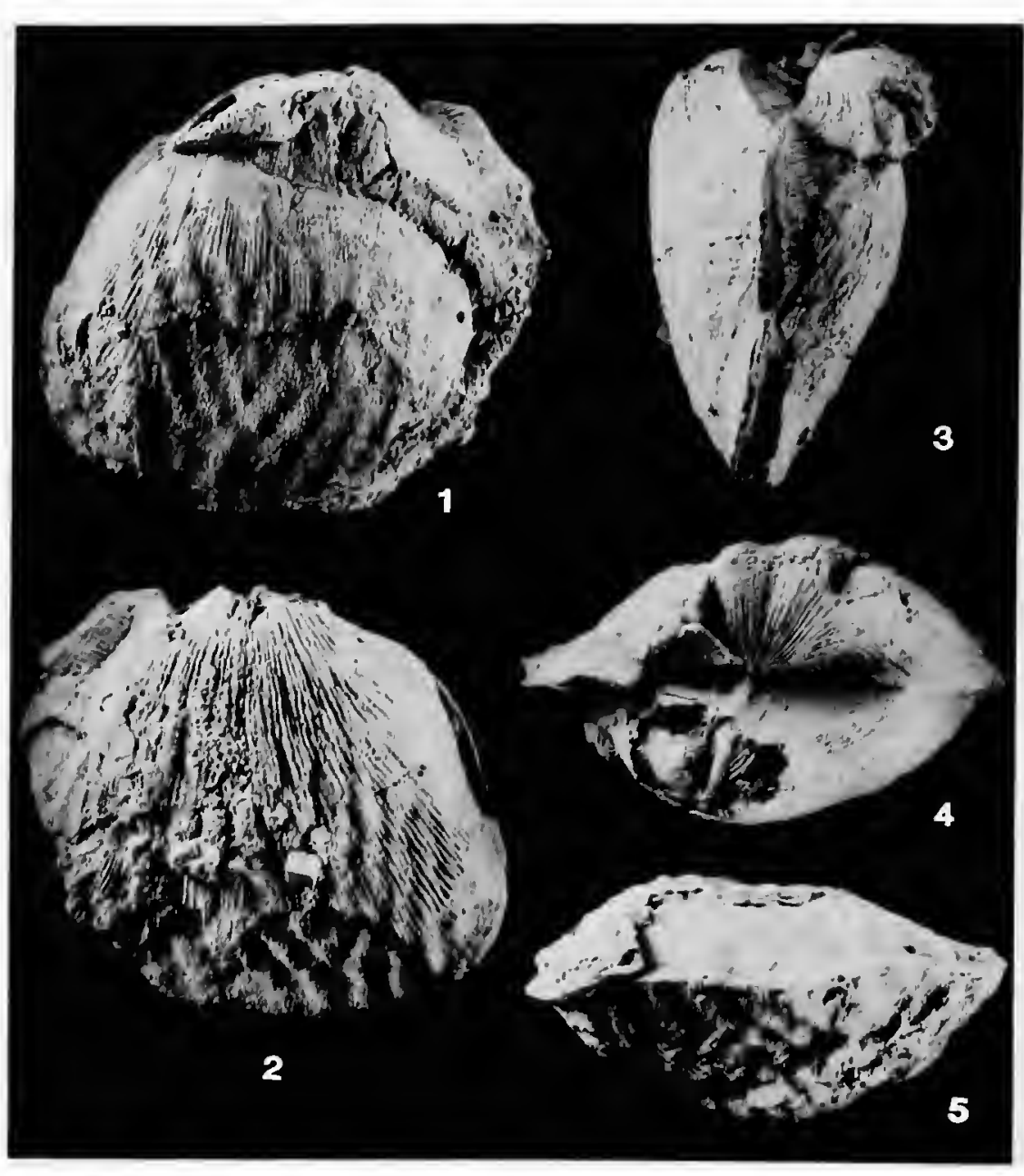

FIGURE 11.-Derbyia pannuciella, new species: 1-5, dorsal, ventral, lateral, posterior, and anterior views ( $\times 1$ ), from section 27, USNM 455991, holotype. (Reduced to $97 \frac{1}{2} \%$ for publication.)

strongly developed in $D$. pannucia and $D$. cincinnata than in $D$. pannuciella.

ETYMOLOGY.-From the Latin, pannucia, meaning wrinkled, and -ella, meaning small.

Family MeEkellidae Stehli, 1954

Genus Meekella White and St. John, 1867

Meekella langdaiensis Liao, 1980

FIGURE 12(1-12)

Meekella langdaiensis Liao, 1980:255, pl. 3: figs. 20-23.

Large, subequally biconvex; dorsal view subcircular; sides broadly rounded; anterior commissure sulcate; hinge shorter than greatest width; plications coarse, increasing by bifurcation, crests angular to subangular, beginning from umbonal region, numbering 12-18 each valve; costellae fine and closely

FIGURE 12 (opposite page).-Meekella langdaiensis Liao: 1-4, ventral, posterior, lateral, and anterior views ( $\times 1$ ), from section 27, USNM 455992; $5-9$, dorsal, ventral, posterior, lateral, and anterior views $(x 1)$, from section 32 , USNM 455993; 10, intemal cast showing impressions of dental plates $(x 1)$, from section 3, USNM 455994; 11, 12, dorsal and ventral views $(\times 1)$, from section 32, USNM 455995. 


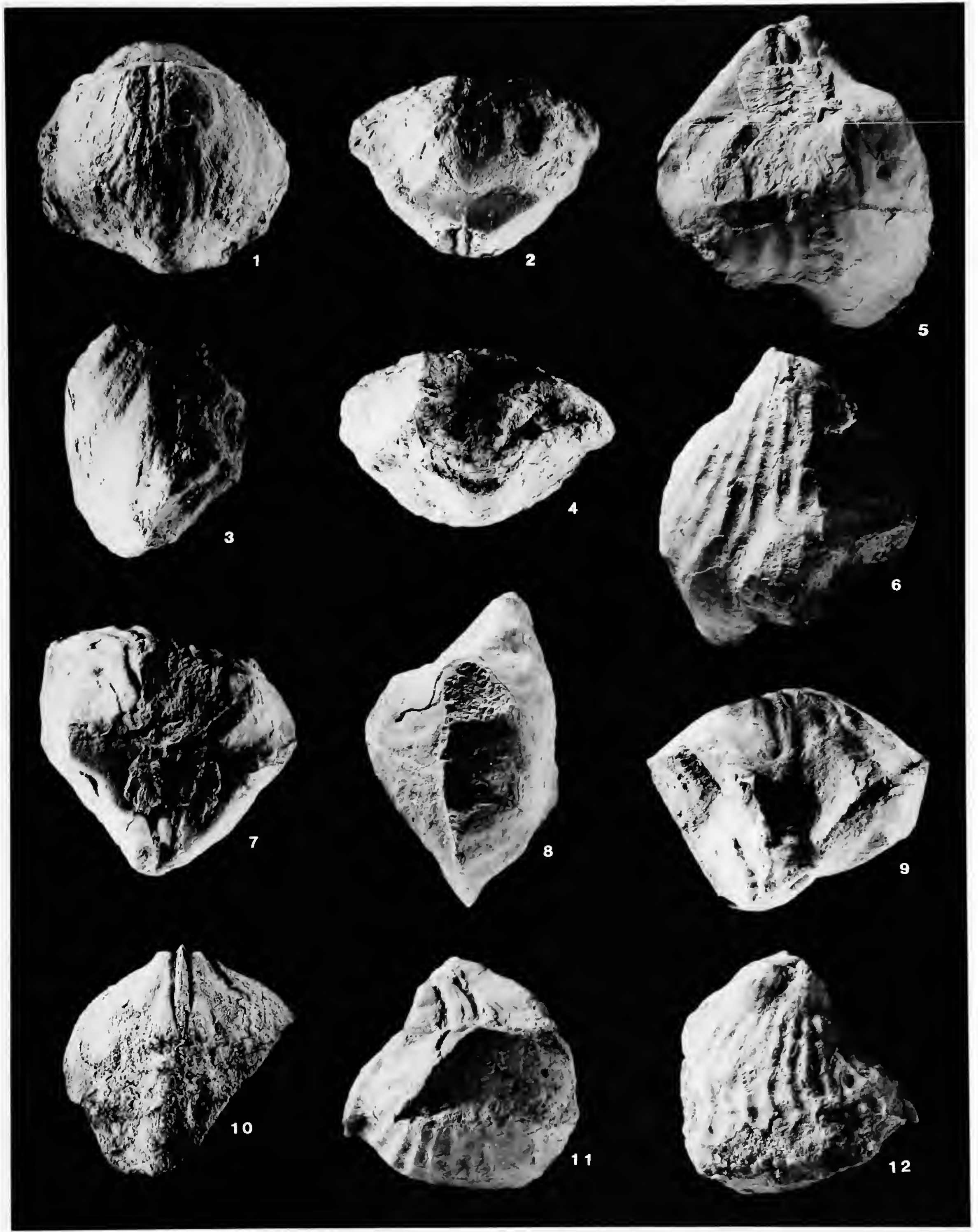


spaced, usually weak, prominent at umbonal region.

Pedicle valve conical; beak moderately sharp, slightly twisted; interarea a subequilateral triangle, fairly flat or slightly concave, apsacline; pseudodeltidium narrow, fold narrow, occupying about $1 / 2$ of valve length. Brachial valve moderately convex, maximum convexity at umbonal region; beak strongly incurved; sulcus moderately deep, occupying about $1 / 4-1 / 3$ of greatest width of valve.

Pedicle valve interior with short dental plates, extending about $1 / 4$ of valve length, parallel and nearly equally distanced at floor, slightly divergent dorsally. Brachial valve interior with high brachiophore supports, divergent forward, forming about $60^{\circ}$ angle.

MEASUREMENTS (mm).-

$\begin{array}{cccccccc} & \begin{array}{c}\text { Pedicle } \\ \text { valve }\end{array} & \begin{array}{c}\text { Brachial } \\ \text { valve }\end{array} & \text { Maximum } & \text { Hinge } & \begin{array}{c}\text { Inter- } \\ \text { area }\end{array} & \text { Thick- } \\ \text { USNM } & \text { length } & \text { length } & \text { width } & \text { width } & \text { length } & \text { ness } \\ 455992 & 40.9 ? & 43.0 & 48.2 & 26.5 & 11.0 ? & 33.7 \\ 455993 & 57.2 & 44.0 & 47.2 ? & 38.8 & 20.8 & 36.9\end{array}$

STRATIGRAPHIC OCCURRENCES AND LOCALITIES.-Longdongchuan Formation: Xikou section, Zhenan County, Shaanxi Province. Longtan Formation: Huangzishan section, Wuxing County, Zhejiang Province.

DiAGNOSIS.-Large, pauciplicate, obvious sulcus on brachial valve. dominant fold on pedicle valve.

COMPARISON.-Meekella langdaiensis Liao is similar to $M$. kueichowensis Huang (1933:27, 28, pl. 3: figs. 19-21, pl. 4: figs. 1-4) in its large size and in features of the interarea; it differs in that the latter has no sulcus and fold and its dental plates are rather thin and close at the valve floor. Meekella cf. kueichowensis Huang (1933:28, 29, pl. 3: fig. 2, pl. 4: figs. 5, 6) has more widely separated and much shorter dental plates than $M$. kueichowensis, and thus resembles $M$. langdaiensis, but it has more than 20 plications in adult specimens (Liao, 1980a:256) and no fold on the pedicle valve.

\section{Superfamily ORThOT ETOIDEA Waagen, 1884}

\section{Family ORThot ETIDAE Waagen, 1884}

Genus Perigeyerella Wang, 1955

\section{Perigeyerella altilosina sp. nov.}

FIGURE 14(10-14)

Medium size for genus; biconvex but shallowly inflated; outline subelliptical, slightly distorted, greatest width at midvalve of brachial valve; hinge line straight, shorter than widest part of shell; anterior commissure rectimarginate, slightly waved dorsally; surface with multicostellae, numbering about 32 per $\mathrm{cm}$, concentric wrinkles irregularly spaced.

Pedicle valve inflated at umbonal region and slightly depressed at anterior $1 / 3$ in lateral profile; anterior profile inflated at middle, with gently inclined slope at each side; beak
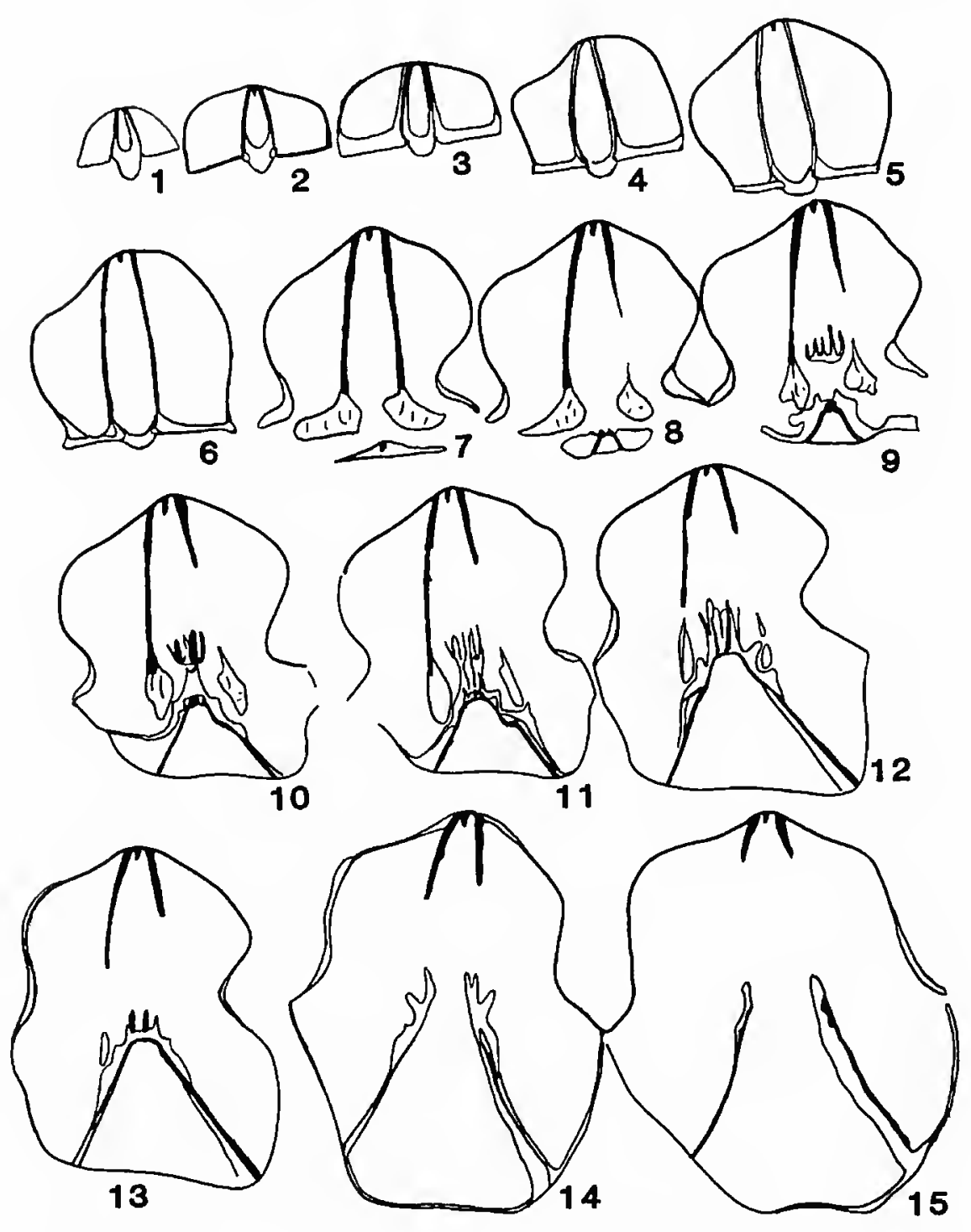

FIGURE 13.-Serial sections of Perigeyerella costellata Wang, USNM 455999. showing intemal features.

blunt, erect; interarea proportionately large, flat, apsacline but nearly orthocline; pseudodeltidium completely arched, narrow, about $1 / 8$ of hinge line, perideltidial area obscure, each side narrower than pseudodeltidium. Brachial valve weakly and evenly convex, forming gentle arciform in both lateral and anterior profiles; beak small, inclined; no sulcus.

Pedicle valve interior with thin, nearly parallel dental plates. Brachial valve interior with flaring extended brachiophore plates. Other features unknown.

HOLOTYPE.-USNM 455996.

MEASUREMENTS ( $\mathrm{mm}$ ).-

$\begin{array}{ccccccc} & \begin{array}{c}\text { Pedicle } \\ \text { valve }\end{array} & \begin{array}{c}\text { Brachial } \\ \text { valve }\end{array} & \text { Maximum } & \text { Hinge } & \begin{array}{c}\text { Inter- } \\ \text { area }\end{array} & \text { Thick- } \\ \text { USNM } & \begin{array}{c}\text { length } \\ \text { length }\end{array} & \text { width } & \text { width } & \text { length } & \text { ness } \\ 455996 & 38.8 & 27.9 & 33.9 & 28.5 & 13.2 & 15.0\end{array}$

STRATIGRAPHIC OCCURRENCE AND LOCALITY.-Longdongchuan Formation: Xikou section, Zhenan County, Shaanxi Province.

Diagnosis.-Medium size, shallow Perigeyerella with large interarea, almost orthocline, and no sulcus on brachial valve. 


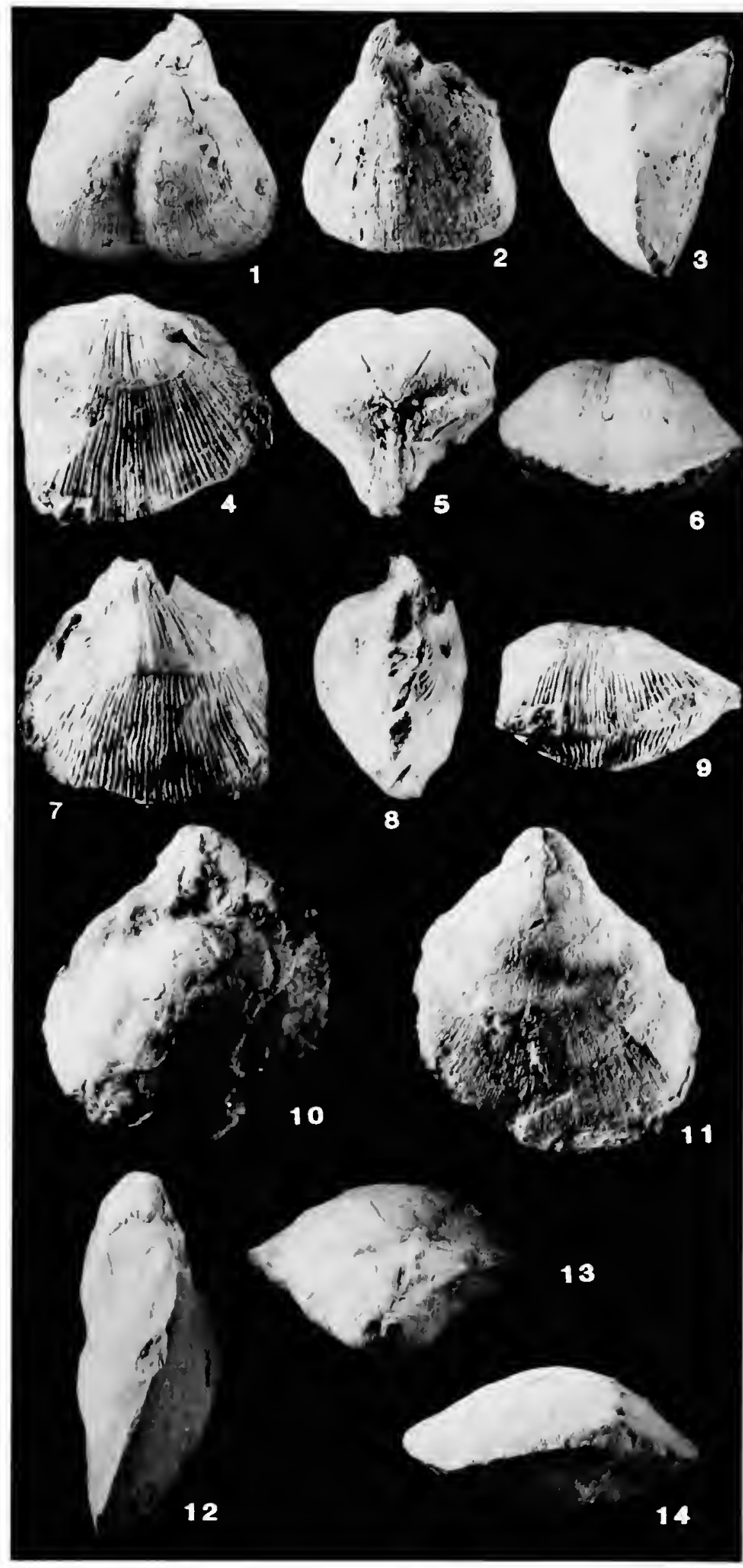

FIGURE 14.-Perigeyerella Wang. 1-9, Perigeyerella costellata Wang: 1-3, 5,6 , dorsal, ventral, lateral, posterior, and anterior views $(\times 1)$, from section 6 , USNM 455997; 4, 7-9, dorsal, ventral, lateral, and anterior views $(\times 1)$, from section 27, USNM 455998. 10-14, Perigeyerella altilosina, new species: dorsal, ventral, lateral, posterior, and anterior views $(x 1)$, from section 32 , USNM 455996, holotype. (Reduced to $97^{1} / 2 \%$ for publication.)
COMPARISON.-This new species differs from $P$. costellata Wang (1955a:347-349, pl. 4A: figs. 1-10) in that the latter has the sulcus on the brachial valve and a semipyramidal pedicle valve (Figure 13). It is similar to $P$. tricosa Grant (1976:63, 64, pl. 11: figs. 1-30) in its brachial valve, which lacks a median depression and is evenly and slightly inflated, but it is readily distinguishable in that the latter is small for the genus and has a lower interarea.

DISCUSSION.-Internal features of this new species were not excavated because traces of dental plates and brachiophore plates on the specimen are comparable to those in specimens of $P$. costellata for which we made serial sections to show internal features of the genus (Figure 13).

The serial sections show a low median septum between the dental plates. This septum extends about the same distance as the dental plates, nearly $1 / 3$ of the pedicle valve length. Wang (1955) recorded "a low spondylium support at posterior extremity" when he set up the genus; therefore, we recommend emending the original description to include the following statement: sometimes having a low median septum in the pedicle valve as a variety of internal features. "Ombonia" magna Greco (1938:24, pl. 1: figs. 18-20, pl. 2: figs. 1-7), which Grant (1976:63) assigned to the genus Perigeyerella, has a median septum in the pedicle valve; its occurrence in this species provides collateral evidence that a ventral median septum may occur in the genus.

ETYMOLOGY.-From the Latin, altilis, meaning fattened and -ina (diminutive suffix), meaning small.

\section{Suborder ChONETIDINA Muir-Wood, 1955}

$$
\text { Superfamily CHONETOIDEA Bronn, } 1862
$$

Family RugosochonetidaE Muir-Wood, 1962

Subfamily ChonetinellinaE Muir-Wood, 1962

\section{Genus Chonetinella Ramsbottom, 1952}

\section{Chonetinella cursothornia sp. nov.}

FiguRe $15(4,6,8-16)$

Small to medium size, transversely subrectangular in outline; widest at hinge; cardinal extremities approximately rectangular or sharply pointed; sides nearly parallel in posterior $1 / 2$, rounded or sloping medially toward anterior; anterior margin broadly rounded, anterior commissure slightly folded; surface costellae numbering about 5-6 per $\mathrm{mm}$ at front margin, fine spicule bases arranged along crests of costellae; posterior margin with 3-4 oblique, coarse, hollow spines at high angle to hinge line on each side of beak.

Pedicle valve gently to moderately convex, anterior profile arched in central region; ears proportionately large, with fine costellae somewhat subdued near hinge; sulcus originating on 


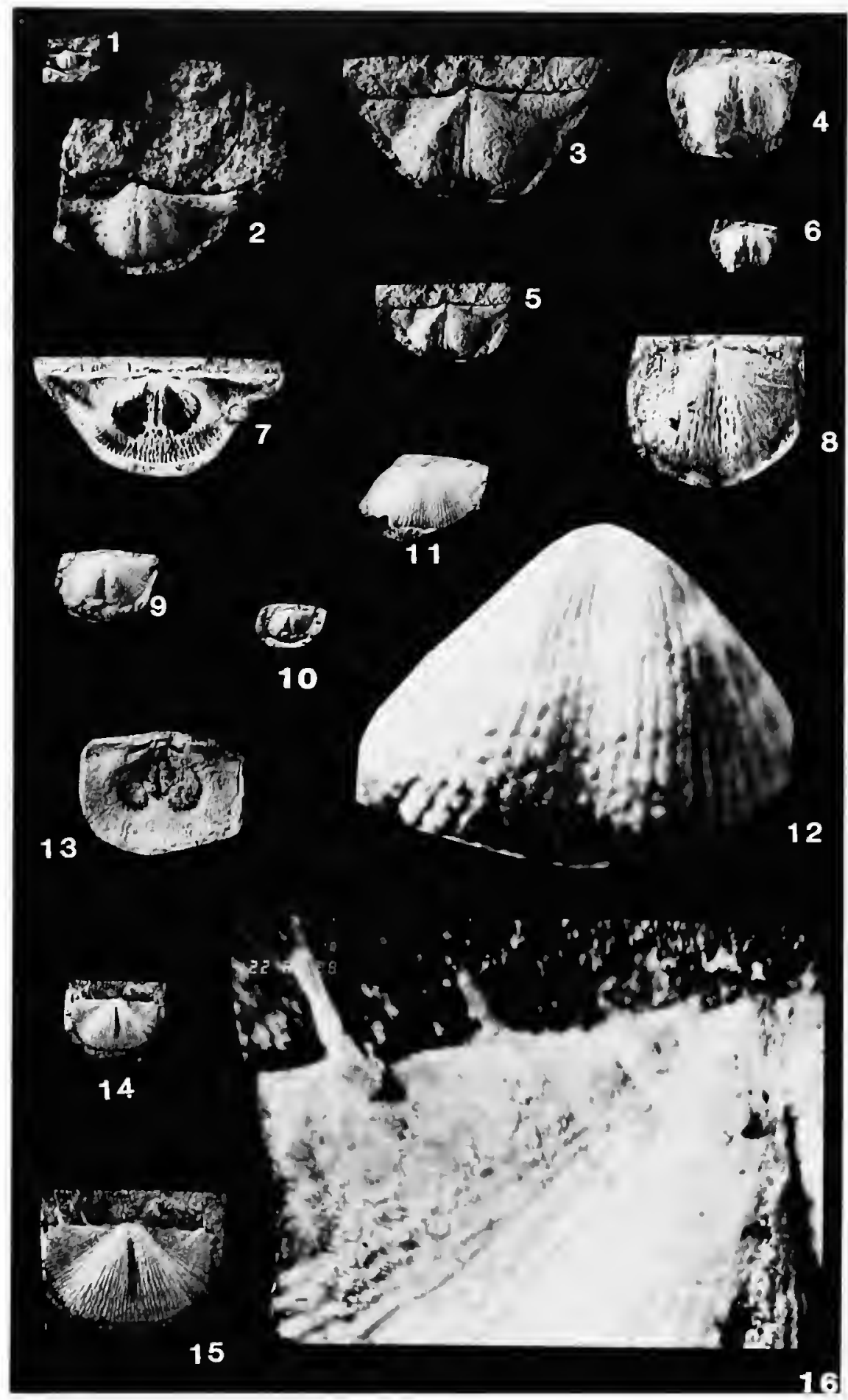

FIGURE 15.-Chonetinella Ramsbottom. 1-3, 5, 7, Chonetinella volitanliopsis $(\mathrm{Xu}): 1,2$, ventral views $(\times 1, \times 4)$, USNM 456004; 7, dorsal view $(\times 2)$, USNM 456005 , both from section 6. 3, 5, ventral views $(\times 2, \times 1)$, USNM 456003, from section 31. 4, 6, 8-16, Chonetinella cursothornia, new species: 4,6 , ventral views $(\times 2, \times 1)$, USNM 456001 , from section 8.8 , ventral view $(\times 2)$, USNM 456007b; 9, 10, ventral views $(\times 2, \times 1)$, USNM 456007a, both from section 17. 11, 12, ventral view and part magnification $(\times 2, \times 10.4)$, USNM 456008; 13, dorsal view ( $\times 2)$, USNM 456002, paratype; both from section 27. 14-16, ventral views and magnification of part of hinge region $(x 1$, $\times 2, \times 20.8$ ), USNM 456000 , holotype, from section 6 . (Reduced to $97 \%$ for publication.)

umbo, moderately deep and narrow near umbonal area, widened and getting shallower from midlength forward. Brachial valve with narrow, low fold.

Pedicle valve interior with short median septum; endospines arranged in radial rows, coarse on ears and sulcus. Brachial valve interior with inner-socket ridges almost parallel to hinge; well-defined brachial ridges; median septum extending to midvalve.
HOLOTYPE.-USNM 456000.

MEASUREMENTS (mm).-

$\begin{array}{ccccc} & \begin{array}{c}\text { Pedicle } \\ \text { valve } \\ \text { length }\end{array} & \begin{array}{c}\text { Surface } \\ \text { length }\end{array} & \begin{array}{c}\text { Hinge } \\ \text { width }\end{array} & \text { Midwidth } \\ \text { USNM } & 5.65 & 6.10 & 9.30 & 9.30 \\ 456000 & 7.20 & 7.60 & 8.60 ? & 8.60 \\ 456006 & 5.20 & 6.70 & 7.00 & 6.10 \\ 456001 & 4.30 & 4.70 ? & & 6.50 \\ 456008 & 3.30 & 3.90 & 4.80 & 4.70 \\ 456007 & 3.30 & & & \end{array}$

STRATIGRAPHIC OCCURRENCES AND LOCALITIES.Changxing Formation: Huayingshan section, Linshui County, Sichuan Province; Beipei section, Zhongqing City, Sichuan Province; Huangzhishan section, Wuxing County, Zhejiang Province. Yinkeng Formation: Meishan section, Changxing County, Zhejiang Province. Lower Daye Formation: Guanyinshan section, Puqi County, Hubei Province.

DIAGNOSIS.-Transverse subrectangular Chonetinella with 3-4 coarse, hollow spines on each side of hinge and moderately deep sulcus beginning from near umbonal area of pedicle valve.

COMPARISON.-Chonetinella cursothornia, new species, is readily distinguishable from $C$. volitanliopsis (Xu) by its subrectangular outline, large ears, and strong spines at posterior margin. It is somewhat similar to $C$. costellata Cooper and Grant (1975:1273, 1274, pl. 479: figs. 1-23) in its subrectangular outlines, fine costellae, and strong spines at posterior margin. But the West Texas species has a relatively large shell, many more spines at the posterior margin, and a poorly developed sulcus.

ETYMOLOGY.-From the Latin, cursor, meaning rapid or brief plus thorn; thus meaning short spines.

\section{Chonetinella volitanliopsis $(\mathrm{Xu}, 1987)$}

FIGURE 15(1-3, 5, 7)

Neochonetes volitanliopsis Xu in Yang et al., 1987:222, pl. 10: fig. 1.

DIAGNOSIS.-Small to medium size, transversely reversely subtrapezoidal outline; cardinal extremities acutely pointed; posterior margin with 3 spines on each side of the beak, 1 at middle of each $1 / 2$ of hinge line; spines long, obliquely originated from hinge line then curved as they grew forward; sulcus narrow or getting wider anteriorly.

STRATIGRAPHIC OCCURRENCES AND LOCALITIES.-Yanshi Formation: Jacing section, Zhanping County, Fijian Province. Lowest Daye Formation: Huayingshan section, Linshui County, Sichuan Province.

DISCUSSION.-This species originally was assigned to Neochonetes, but now it is placed in Chonetinella because it differs from typical species of Neochonetes, which have strong lateral vascular trunks parallel to each other in the pedicle valve and no narrow and deep sulcus on that valve. Instead, $C$. volitanliopsis is small, has endospines in radial rows on both valves that are coarse on the ears and the sulcus area, has 
brachial ridges that extend along the lateral and anterior margins to near the median septum that then recurve at a sharp angle, and has a short septum in the pedicle valve. These features suggest that it should be attributed to the genus Chonetinella.

\section{Subfamily Rugosochonetinae Muir-Wood, 1962}

\section{Fanichonetes gen. nov.}

Small- to medium-size shell, transversely subrectangular to semicircular in outline; hinge slightly shorter or equal to maximum width; cardinal extremities varying from slightly acute to slightly obtuse; shallow sulcus on pedicle valve; ears large, usually well defined; surface strongly costellate, increasing by bifurcation, subdued on ears, becoming smooth near hinge line; growth lines irregularly spaced, extending to ears; spines inclined mesially at low angle to hinge line, crowded near beak, distally inclined near cardinal extremities.

Pedicle interior with short median septum; endospines in radial rows, coarse on ears and middle part. Brachial valve with bifid cardinal process and alveolus.

DIAGNOSIS.-Transverse outline, strongly costellate, welldeveloped growth lines, and spines mostly inclined toward midline.

COMPARISON.-This genus is most like Rugosochonetes Sokolskaya (1950:23; see also Muir-Wood, 1962:64-68) in its transverse outline, well-developed growth lines, internal features, spines that incline toward the midline, and strong costellae. It resembles Neochonetes Muir-Wood (1962:87-89, pl. 10: figs. 8-15, pl. 11: figs. 7, 8; Cooper and Grant, $1975: 1217,1218$ ) in its transverse outline, but it is readily distinguished from Neochonetes by its spines that mostly incline mesially. Fanichonetes has no strong lateral vascular trunks and has strong costellae that normally are coarser than in Neochonetes. Chonetinella Ramsbottom (1952:13; MuirWood, 1962:85-87, pl. 9: figs. 10-17), with strong costellae and deep sulcus, is somewhat similar to Fanichonetes, however, it differs in not having well-developed growth lines and inwardly inclined spines.

TYPE SPECIES.-Fanichonetes campigia sp. nov.

ETYMOLOGY.-From the Latin, fanum, meaning temple. The gender of -etes is ambiguous; it is treated here as feminine.

\section{Fanichonetes campigia sp. nov.}

FIGURE 16(1-32)

DIAGNOSIS.-Small to medium size; transversely subrectangular; sulcus shallow on pedicle valve; strongly costellate, numbering about $11-13$ per $5 \mathrm{~mm}$ at anterior margin; ears large; spines on posterior margin mostly inclined toward midline, numbering about 6-10, crowded near beak; growth lines well developed.

HOLOTYPE.-USNM 456011.
MEASUREMENTS (mm).-Pedicle valve.

$\begin{array}{cccccc}\text { USNM } & \begin{array}{c}\text { Surface } \\ \text { length }\end{array} & \begin{array}{c}\text { Hinge } \\ \text { length }\end{array} & \text { Width } & \text { Midwidth } & \begin{array}{c}\text { Spines } \\ \text { per } \\ \text { side }\end{array} \\ 456009 & 10.1 & 11.3 & 12.8 & 14.5 & 8 \\ 456010 & 9.8 & 10.6 & 14.3 & 14.3 & 7 \\ 456011 & 6.5 & 7.0 & 9.8 & 10.7 & 6 \\ 456012 & 8.2 & 9.1 & 11.8 & 13.7 & - \\ 456013 & 7.6 & 7.9 & 13.3 & 13.7 & - \\ 456014 & 7.5 & 7.8 & 10.6 & 12.8 & - \\ 456015 & 6.3 & 6.5 & 8.9 ? & 10.4 & -\end{array}$

STRATIGRAPHIC OCCURRENCES AND LOCALITIES.-Upper Member of Paoshui Formation: Paoshui section, Laibin County, Guangxi Province. Wangpanli Formation: Lian County, Guangdong Province. Changxing Formation: Huangzhishan section, Wuxing County, Zhejiang Province. Lowermost Xikou Formation: Yading section, Zhuangping County, Fujian Province.

ETYMOLOGY.-From the Greek, camar, a vaulted chamber, and pygia, posterior, tail.

\section{Suborder Productidina Waagen, 1883 \\ Superfamily Productoidea Gray, 1840 \\ Family ChONeTELlidaE Likharev, 1960}

\section{Genus Cathaysia Ching, 1966}

Cathaysia Ching in Wang et al., 1966:372-374, fig. 287.

Small, transverse outline; moderately concavo-convex; ears large, well demarcated from visceral disc of shell by either narrow trough, strong concavity, or different ornamentation; sulcus usually originating about midlength, shallow and widened on geniculation; interarea narrow; surface strongly costellate, crests rounded, increasing by bifurcation; ears normally smooth; central wrinkles well developed, especially on ears; cardinal spines oblique, about 2-3 per side, biggest spines on cardinal extremities; both sides of sulcus on geniculation bearing several spines.

Pedicle valve interior with 2 pairs of adductor marks, 1 pair near umbonal area small, kidney-shape, another pair distal, somewhat large; diductor marks elongate oval surrounding adductors; no median septum. Brachial valve interior with bifid cardinal processes; median septum thin and low; brachial ridges lunate; 2 pairs of adductors posterior to brachial ridges; endospines around brachial ridges large, those near anterior margin of shell small.

COMPARISON.-The genus Cathaysia Ching is similar to Chonetella Waagen (1884:613, 657; Muir-Wood and Cooper, 1960:219-221, pl. 69: figs. 1-7) in its "Chonetoid-shape, narrow coelomic cavity, large ears, spines at posterior margin ..." (Ching, 1966:373). In establishing the genus, Ching $(1966: 373,374)$ pointed out that Cathaysia has "geniculation" formed gently, wrinkles dominant on ears, only 


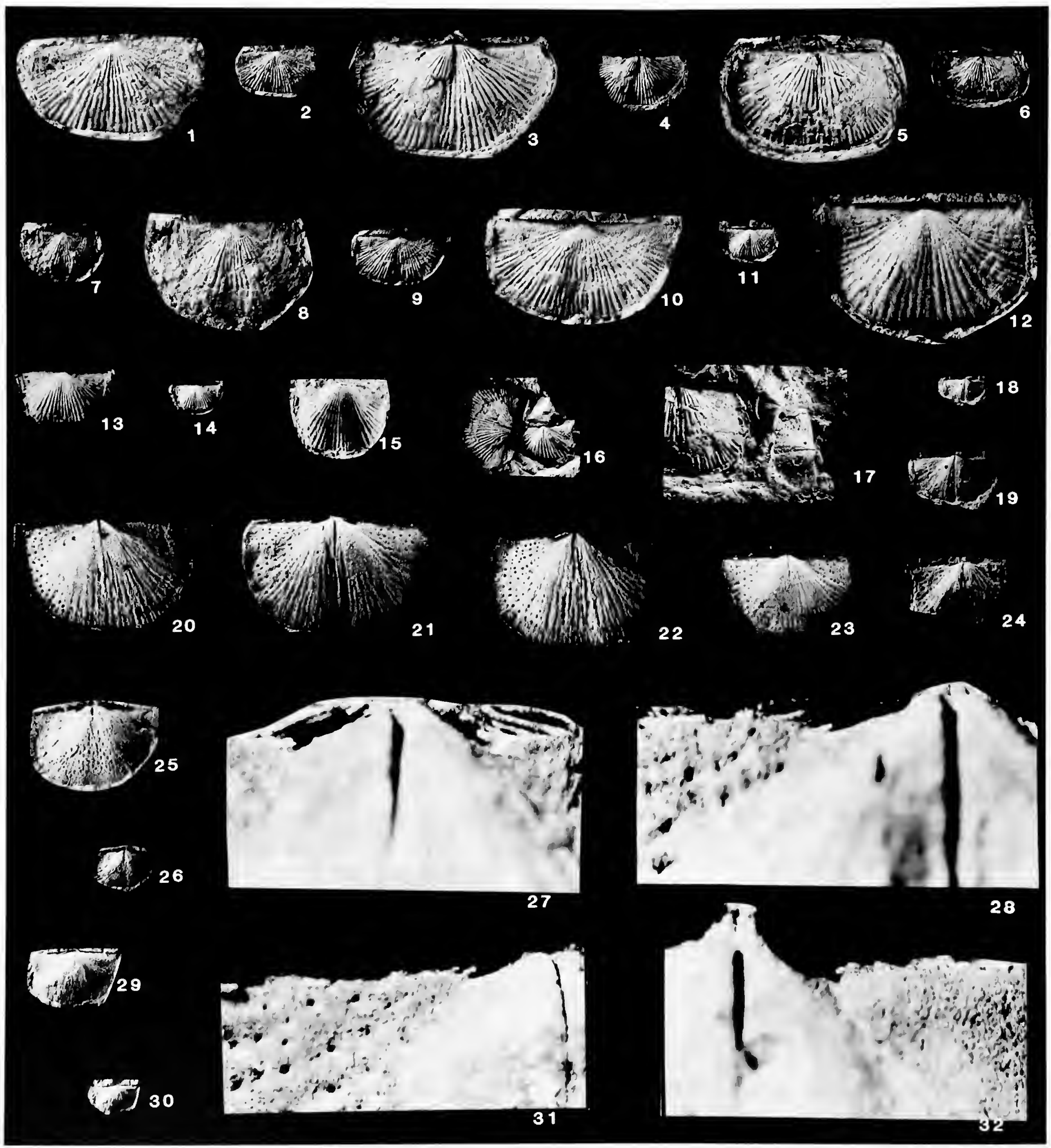

FIGURE 16.-Fanichonetes campigia, new species: 1,2 , ventral views $(\times 2, \times 1)$, USNM 456012; 5, 6. ventral views $(\times 2, \times 1)$, USNM 456014a; 7, 8, ventral views $(x 1, \times 2)$, USNM 456013; 17-19, ventral views $(\times 2, \times 1, \times 2$, respectively), USNM 456014b; all from section $31.3,4,16$, ventral valves $(x 2$, $\times 1, x 1$, respectively), USNM 456015 , from section $34.9,10$, ventral valve $(x 1$, $\times 2)$, USNM 456019a; 13, 14, ventral valve $(\times 2, \times 1)$, USNM 456019b; 24 , ventral valve $(\times 2)$, USNM 456017: 25,26 , ventral valve $(\times 2, \times 1)$, USNM 456018 a: 29,30 , ventral valve $(\times 2, \times 1)$, USNM 456018 b; all from section 30 .
11,12 , ventral valves $(x 1, x 4)$, USNM 456016. 15 , ventral valve $(\times 2)$, USNM 456206, from section $26.20,32$. dorsal interior mold $(\times 2)$ and magnification of part of hinge region $(x 10,4)$, USNM 456009 , paratype; $22,27,31$, ventral valve interior mold $(\times 2)$ and magnification of part of hinge region $(\times 10.4)$, USNM 456010a: 23, ventral valve interior mold, USNM $456010 \mathrm{~b} ; 21,28$, ventral valve interior mold $(\times 2)$ and magnification of part of hinge region $(\times 10.4)$, USNM 456011 , holotype; all from section 15. 
2-3 spines in row per side of the beak, and 2-4 spines existing on geniculation at each side of sulcus; in contrast, the genus Chonetella has no geniculation, wrinkles on ears, and spines in a row, excepting along posterior margin, existing between ears and visceral disc. Furthermore, the important features of Chonetella are the pedicle valve, which has an anterior median fold that forms a $V$-shape extension, and the brachial valve, which has an anterior sulcus.

Geologic Range.-Pennian, Asia.

TYPE SPECIES.-Productus chonetoides Chao (1927:62, 63, pl. 16: figs. 1-5).

\section{Cathaysia sinuata Chan, 1979}

FIGURE 17(1-22)

Cathaysia sinuala Chan in Hou et al., 1979:76, 77, pl. 13: figs. 6-9.-Chan in Z.Y. Yang et al., 1987:223, pl. 10: figs. 19, 20, 22, 23.

Cathaysia sulcatifera Liao, 1979, pl. 1: figs. 19, 20; 1980a:261, pl. 6: figs. 8-10.-Liao in Zhao et al., 1981:53, pl. 8: figs. 15, 16.

DIAGNOSIS.-Small, transversely trapezoidal or semicircular; strongly concavo-convex; interarea rather narrow; beak incurved; cardinal extremities blunt; ears large, either flat or slightly arched; sulcus narrow and deep, originating from umbonal area. usually becoming shallow, flattened, or forming small low fold at trail; surface with strong costellae, rounded at crest. casually bifurcate, numbering about 14-30 near anterior margin; wrinkles faint but clearly visible on ears; $2-3$ spines at posterior margin in a row at each side of beak, oblique posterior-laterally at high angle to hinge line, biggest one extending from each cardinal extremity, sometimes horizontal extension.

Interior structures mostly unknown. but endospine scars visible in some specimens; no median septum in pedicle valve.

MEASUREMENTS (mm).--Pedicle valve.

$\begin{array}{cccccc}\text { USNM } & \begin{array}{c}\text { Surface } \\ \text { length }\end{array} & \begin{array}{c}\text { Hinge } \\ \text { length }\end{array} & \text { Width } & \text { Midwidth } & \begin{array}{c}\text { Spines } \\ \text { per } \\ \text { side }\end{array} \\ 456020 & 6.2 & 8.1 & 8.8 & 9.1 & 2 \\ 456021 & 5.2 & 5.9 & 8.1 & 7.8 & 2 \\ 456022 & 6.3 & 7.8 & 10.0 & 8.2 & 2-3 ? \\ 456023 & 7.6 & 8.2 & 8.7 & 8.8 & 2 \\ 456024 & 6.5 & 9.4 & 10.4 & 9.8 ? & 2 \\ 456025 & 7.9 & 9.7 & 11.7 & 11.7 ? & - \\ 456026 & 5.0 & 5.6 & 8.0 ? & 8.5 & 2\end{array}$

STRATIGRAPHIC OCCURRENCES AND LOCALITIES.-Lower Yinkeng Formation and Upper Changxing Formation: Meishan section, Changxing County, Zhejiang Province; Yutangjiao section, Nantong County, Sichuan Province. Cuipingshan and Yanshi formations: Yanshi section, Longyan County, Fujian Province.

COMPARISON.-Cathaysia sinuata Chan is characterized by having a narrow, deep sulcus extending from the umbonal area to the trail on the pedicle valve. strong coarse costellae, proportionately large ears with faint wrinkles on it, and only

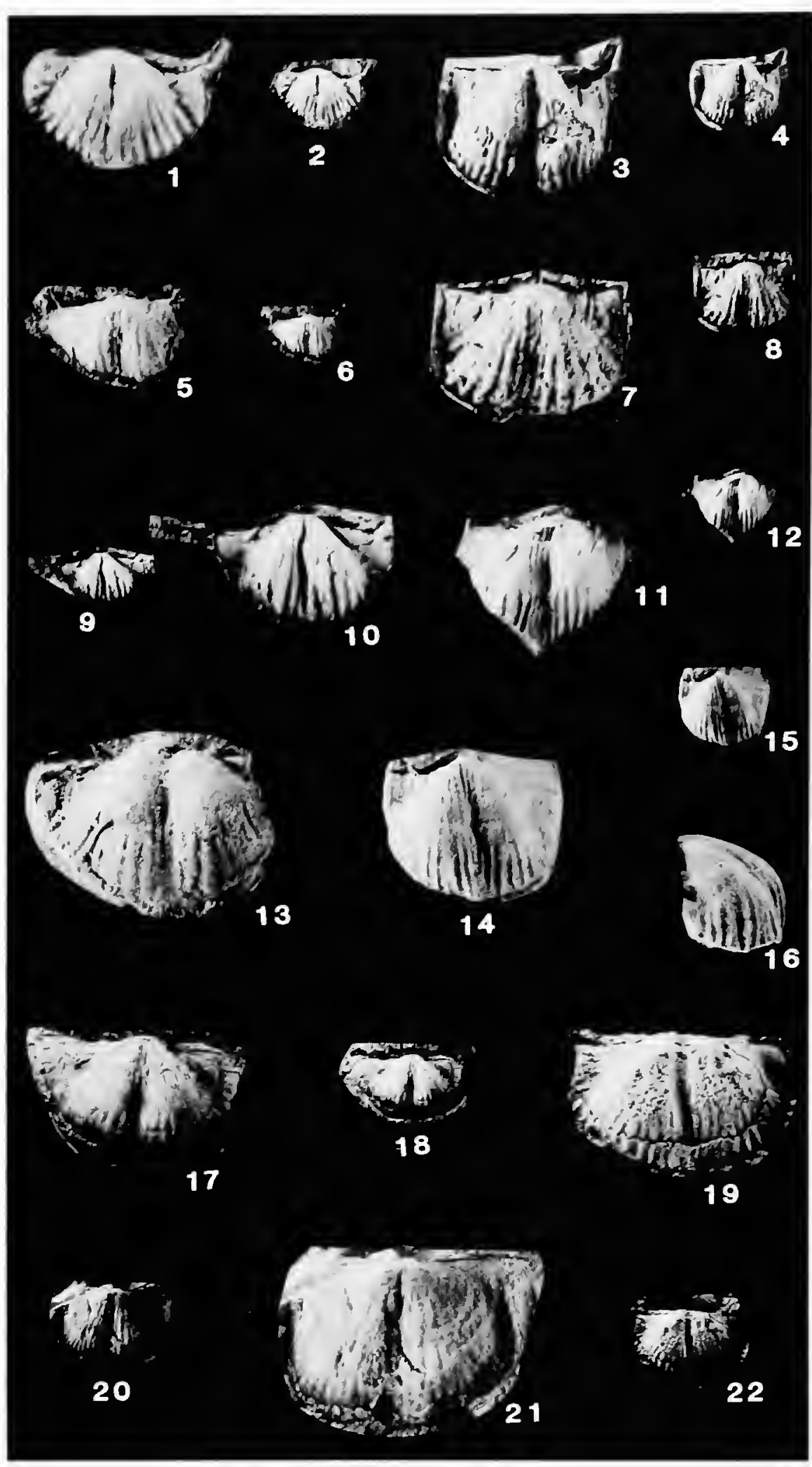

FIGURE 17.-Cathaysia sinuata Chan, all ventral valves: $1,2(\times 2, \times 1)$, USNM $456020 ; 17,18(\times 2, \times 1)$, USNM 456021; both from section $26.3,4(\times 2, \times 1)$, USNM 456023; 5, 6, $(\times 2, \times 1)$, USNM 456006; $13(\times 2)$, USNM 456026; all from section 27. 9, $10(\times 1, \times 2)$, USNM 456022, from section $9.7,8(\times 2, \times 1)$, USNM 456207; $11,12(\times 2, \times 1)$, USNM 456024; $14,15(\times 2, \times 1)$, and 16 , lateral view $(\times 2)$, USNM 456208; 19, $22(\times 2, \times 1)$, USNM 456025a; $20,21(\times 1, \times 2)$, USNM $456025 \mathrm{~b}$; all from section 31 .

2-3 spines at each side of the beak. These features, therefore, are readily distinguishable from $C$. chonetoides (Chao, 1927:62, 63, pl. 16: figs. 1-5). It is similar to Cathaysia orbicularis Liao (1980a:261, pl. 6: figs. 1-4) in its transverse outline, strong costellae, and variable ears, but it differs in its deep sulcus, faint wrinkles on ears, and relatively large number of costellae. 
DISCUSSION.-Liao (1980a:261, pl. 6: figs. 8-10) named the species Cathaysia sulcatifera, based on specimens from the Changxing Formation of the Qiaozishan section, Anshun County, Guizhou Province, which are the same as specimens from the north area of Guangdong Province that were named $C$. sinuata by Chan (in Hou et al., 1979). This name has priority, so the name $C$. sulcatifera must be abandoned.

Liao (in Zhao et al., 1981:53, 83, 84) named the genus Paryphella, based upon the type species $C$. sulcatifera, which is a junior synonym of $C$. sinuata Chan. The reasons that he advanced for separating this species from Cathaysia are that the genus Cathaysia is large, has fine costellae, spines on the visceral disc, and no "ear-curtains" (Liao in Zhao et al., 1981:53). The author explains the concept of ear-curtains as "posterial lateral margins bent abruptly to brachial valve" (1981:83) and encircling postero-laterally the ears of the brachial valve (1981:53). It is true that the phenomenon of ear-curtained commonly occurs in every species of the genus Cathaysia, even in C. chonetoides (Chao, 1927, pl. 16: fig. 4; Huang, 1932, pl. 1: figs. 10,11), because the shape of the ears is variable in Cathaysia. If the ears were strongly inflated, that would produce the phenomenon of ear-curtained; on the other hand, ears in many specimens are flat, for instance, some specimens of $C$. sulcatifera Liao (1980a, pl. 6: fig. 9) seem not sufficiently inflated to produce the ear-curtained effect, as the author described "ears large, flat" (Liao, 1980a:261). The specimens from South China indicate that the phenomenon of ear-curtained may be an inconstant feature. Definitely, adults of $C$. chonetoides are relatively large and have fine costellae; these features are useful for discriminating among species rather than among genera. Visceral-disc spines were not found in our collections of $C$. chonetoides and $C$. sinuata except for a few tubercles that may represent spine scars. It could not be decided which is correct: Liao's description of the species $C$. sulcatifera (1980a:261) as "having several spines on lateral surface of shell" or the description of the genus Paryphella (Liao, 1981:53, 83) as having "no spines on shell surface [and a] lack of ventral and lateral spines." In view of these inconsistencies, we consider that Paryphella is a synonym of Cathaysia.

Cathaysia speciosa Chan (in Hou et al., 1979:76, pl. 9: figs. 4-7) is characterized by its strongly convex, relatively coarse costellae, slightly curved ears, and clearly visible coarse wrinkles. These features seemingly cannot be distinguished from $C$. sinuata Chan except for the sulcus. The holotype of $C$. speciosa is shown in Chan (in Hou et al., 1979, pl. 9: figs. 4, 5) to have a narrow, deep sulcus as in $C$. sinuata $(1979$, pl. 9: figs. 8. 9). Judging from illustrations of other specimens assigned to C. speciosa by Chan (in Hou et al., 1979, pl. 9: figs. 6, 7), it is so much like $C$. chonetoides that it seems unnecessary to keep the name $C$. speciosa Chan.

\section{Cathaysia spiriferoides sp. nov.}

FIGURe 18(1-15)

Medium size for genus; reversely trapezoid in outline; pedicle valve moderately convex and brachial valve shallowly concave; widest along hinge, cardinal extremities acute and slightly alate; beak sharply pointed, bent over hinge line; ears moderately large, usually slightly inflated; sulcus shallow or moderately deep, originating from anterior to umbonal region, gradually widening to anterior margin forming triangular shape; surface with strong costellae, rounded at crest, simple at sulcus floor, bifurcated at lateral sides; strong and irregular wrinkles, especially at ears, extending to lateral sides of visceral disc; 3-5 pairs of spines at posterior margin, vertical to hinge.

Pedicle valve interior having no median septum; endospines fine, distributed radially along traces of interspaces between costellae. Brachial valve interior with low, single(?) cardinal process; median septum extending to midvalve, unconnected to cardinal process, suggesting alveolus existed; brachial ridges present.

SYNTYPES.-USNM 456006a-f, 456027a,b, 456030, 456209.

MEASUREMENTS (mm).-Pedicle valve.

$\begin{array}{ccccc}\text { USNM } & \begin{array}{c}\text { Surface } \\ \text { length }\end{array} & \begin{array}{c}\text { Hinge } \\ \text { length }\end{array} & \text { Width } & \text { Midwidth } \\ 456027 & 9.3 & 12.3 & 12.4 & 10.9 \\ 456028 & 9.7 & 10.1 & ? & 12.0 \\ 456030 & 8.4 & 8.8 & 9.0 & 8.4\end{array}$

STRATIGRAPHIC OCCURRENCES AND LOCALITIES.-Longtan Formation: Meitian section, Yizhang County, Hunan Province. Upper Cuipingshan to Lower Yanshi formations: Yanshi section, Longyan County, Fujian Province.

COMPARISON.-Cathaysia spiriferoides, new species, resembles $C$. chonetoides (Chao) in its size, numerous costellae,

FIGURE 18 (opposite page).-Cathaysia. 1-15, Cathaysia spiriferoides, new species: $1(\times 2)$, ventral valve, USNM 456027a; $2,3(\times 2, \times 1)$, ventral valve, USNM 456027b, both syntypes from section 23. 4, $5(\times 2, \times 1)$, ventral valve, USNM 456006f; $6,7(\times 2, \times 1)$, ventral valve, USNM 456030;8,9 $(\times 2, \times 1)$, brachial interior molds, USNM 456006a; $10(\times 2)$, brachial interior mold, USNM 456006b; $11(\times 2)$, ventral valve, USNM 456006c; $12,13(\times 2, \times 1)$, ventral valve, USNM 456006d; $14,15(\times 2, \times 1)$, ventral valve, USNM 456006e, all syntypes, all from section 31. 16-35, Cathaysia chonetoides (Chao), all ventral valves except 25 and 27 , which are brachial interior molds: $16(\times 2)$, USNM 456027c; 17, $18(\times 2, \times 1)$, USNM 456027d; $21(\times 2)$, USNM 456027e; all from section 23. 19, $20(\times 2, \times 1)$, USNM 456026, from section 27. 22, 23 $(\times 2, \times 1)$, USNM 456032, from section 26. $24(\times 2)$, USNM 456034, from section 10. $25(\times 1)$, USNM 456035, from section $15.26(\times 2)$, USNM 456037a; $27(\times 2)$, USNM 456037b, both from section $27.28(\times 2)$, USNM 456036, from section 8.29 ( $\times 2)$, USNM 456031b; $30(\times 2)$, USNM 456031c; 31 ( $\times 2)$, USNM $456031 \mathrm{a}$, all from section $26.32,33(\times 2, \times 1)$, USNM 456038, from section 31 . $34,35(\times 3, \times 1)$, USNM 456033, from section 6 . 

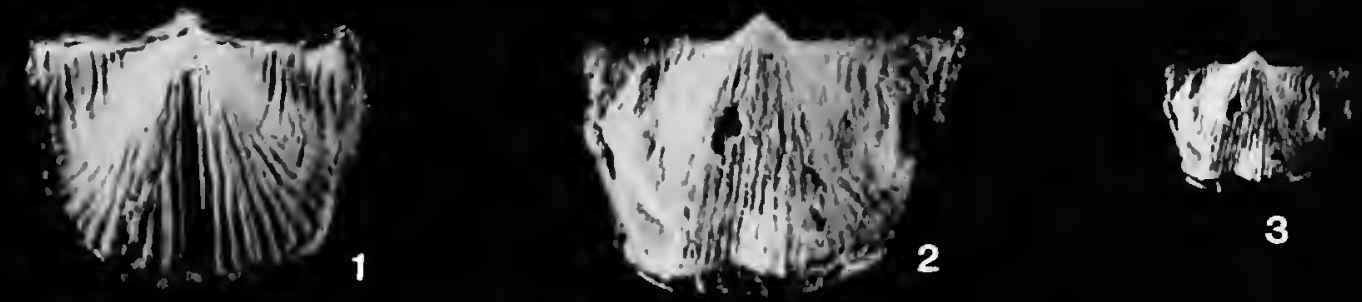

3

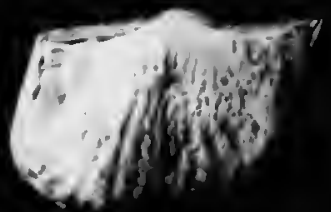

toif

4
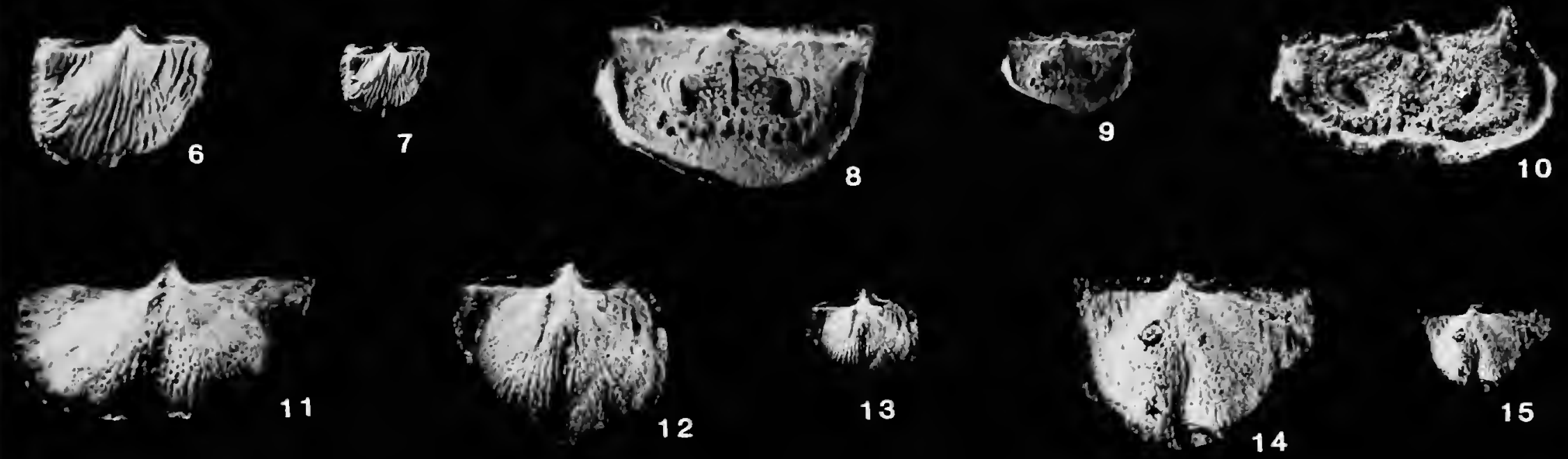

12
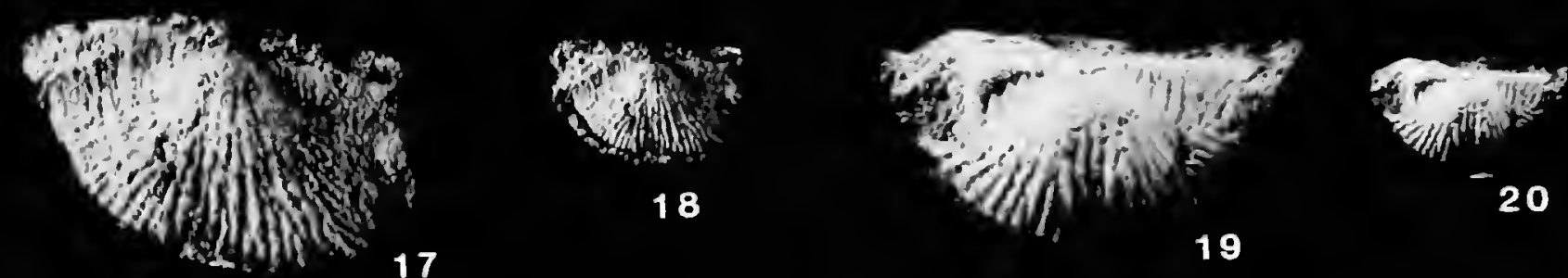

16
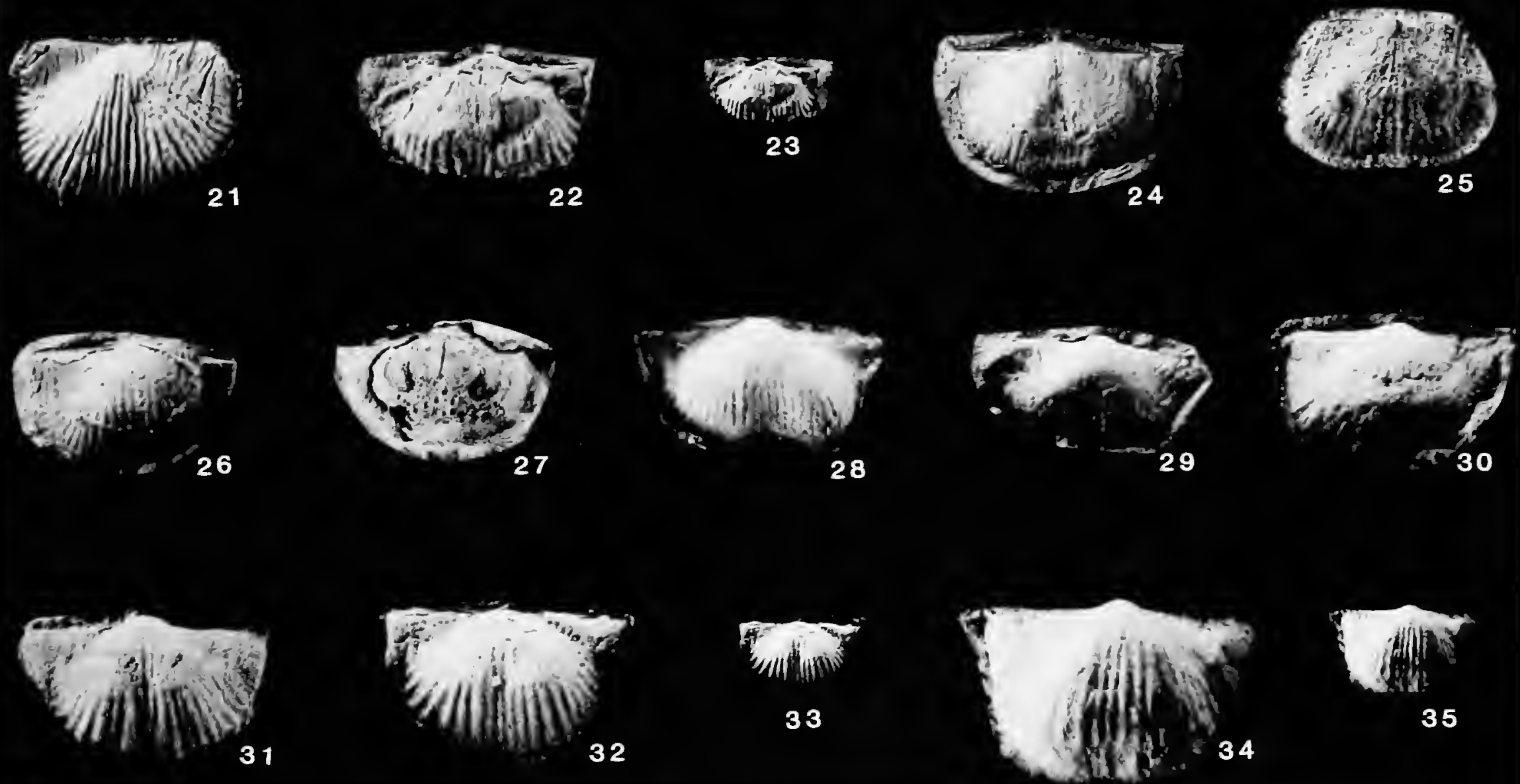

31 
and spines at posterior margin; it differs in its alate cardinal extremities, erect and sharply pointed beak, triangular-shape sulcus, and strong central wrinkles. It is readily distinguishable from $C$. sinuata Chan by its shallow and triangular-shape sulcus, erect and sharply pointed beak, and acute cardinal extremitics. It is easily discriminated from $C$. orbicularis Liao, owing to the latter's very small size, strongly convex pedicle valve, and weakly developed wrinkles.

ETYMOLOGY.-From the genus spirifer plus -oides, Greek for "looks like."

\section{Cathaysia obicularis Liao, 1980}

FIGURE 19(1-21)

Paryphella triquetra Liao, 1979, pl. 1: fig. 18.-Liao in Zhao et al., 1981:53, 54, 84, pl. 8: figs. 18-22.

Cathaysia orbicularis Liao, 1980a:261, pl. 6: figs. 1-4.

DIAGNOSIS.-Small for genus, subtriangular in outline; strongly convex at visceral disc of pedicle valve; ears variable, usually large and strongly or moderately arched; beak slightly swollen, protruding over hinge line; cardinal extremities rectangular or slightly rounded; sulcus absent, very shallow, or a slight depression at middle part of pedicle valve, in several specimens forming small anterior fold including 2-3 costellae, slightly protuberant over lateral costcllae; 2-3 spines at posterior margin at each side of beak.

MEASUREMENTS (mm).-_Pedicle valve.

$\begin{array}{ccccc}\text { USNM } & \begin{array}{c}\text { Surface } \\ \text { length }\end{array} & \begin{array}{c}\text { Hinge } \\ \text { length }\end{array} & \text { Width } & \text { Midwidth } \\ 456041 & 3.2 & 4.2 & 6.8 & 4.8 \\ 456042 & 3.0 & 3.9 & 4.3 & 3.6 \\ 456043 & 2.8 & 3.2 & 3.1 & 3.8 \\ 456039 & 4.9 & 6.4 & 7.3 & 7.3 \\ 456040 & 4.3 & 5.7 & 5.8 & 5.5 \\ 456044 & 4.6 & 6.6 & 7.8 ? & 6.3 \\ 456045 & 5.3 & 6.0 & 7.2 & 6.9\end{array}$

STRATIGRAPHIC OCCURRENCES AND LOCALITIES. Changxing Formation and lower member of Yinkeng Formation: Meishan section, Changxing County, Zhejiang Province. Lower Yinking Formation: Majiashan section, Chao County, Anhui Province. Lower Member of Dayc Formation: Huayingshan section, Linshui County, Sichuan Province.

COMPARISON.-Cathaysia orbicularis Liao obviously differs from $C$. chonetoides (Chao) in its small size, strongly convex visceral disc of pedicle valve, relatively coarse and few costellae. It is similar to juvenile individuals of $C$. sinuata $C$ han in its outline, variable ears, relatively coarse costellae, and small anterior fold on the pedicle valve, but it usually has no sulcus, even though sometimes it has a very shallow sulcus, rather strongly inflated pedicle valve, and a few costellae that are especially visible on adult individuals.

DISCUSSION.-Paryphella triquetra Liao, described as a new species in 1981, but also a nomen nudum in 1979, actually is no different from $C$. orbicularis Liao. Comparing both species, he said that $P$. triquetra has a very sinall shell, lower convexity,

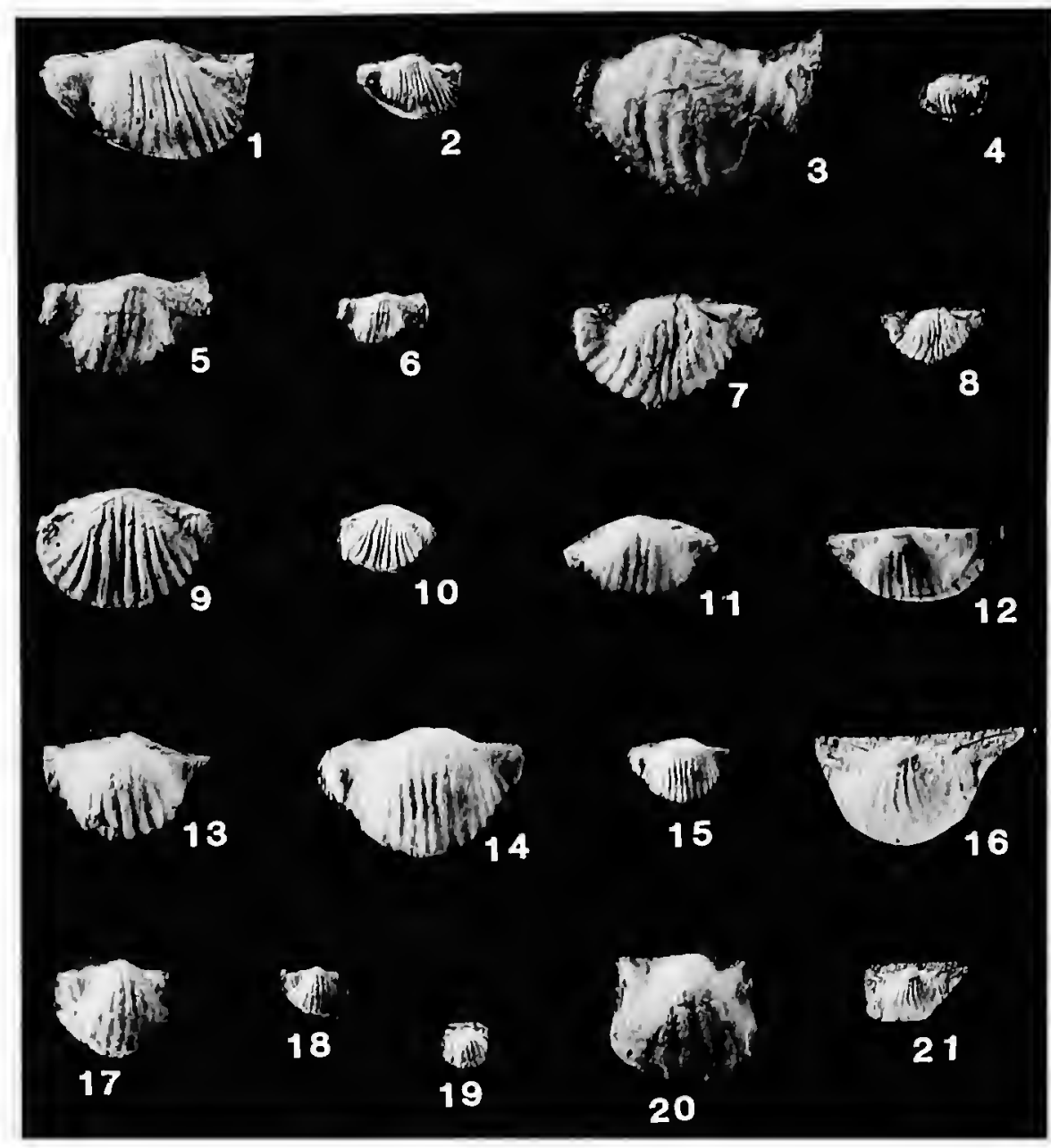

FIGURE 19.-Cathaysia orbicularis Liao, all ventral valves: $1,2(\times 2, \times 1)$, USNM 456042, from section 32. 3, $4(\times 3.5, \times 1)$, USNM 456041a; 5, $6(\times 2, \times 1)$, USNM 456039; 7, $8(\times 2, \times 1)$, USNM 456041b; $11(\times 2)$, USNM 456040a; 16, $21(\times 2, \times 1)$, USNM 456040b; 19, $20(\times 1, \times 3)$, USNM 456043; all from section 27. $9,10(\times 2, \times 1)$, USNM 456046, from section 24. $12(\times 2)$, USNM 456048; $13(\times 2)$, USNM 456047), both from section 26. 14, $15(\times 2, \times 1)$, USNM $456045 ; 17,18(\times 2, \times 1)$, USNM 456044, both from section 6 .

triangular-shape outline except ears; whereas the species $C$. orbicularis has a strongly convex shell (semispheroidal) and many more costellae (Liao, 1981:53, 54). To judge by our collections and by the pictures (Liao, 1979, pl. 1: fig. 18; 1980a, pl. 6: figs. 1-4; Liao in Zhao et al., 1981, pl. 8: figs. 18-22) and tables comparing species (Liao, 1984:282) presented by Liao, the two species range in size and convexity along a continuous spectrum that renders it impossible to separate species on such ephemeral features. The number of costellae in "Paryphella triquetra" is about 10-15 by Liao's account, and in Calhaysia orbicularis it is about 14-17, measuring from Liao's pictures. Our collections indicate about 10-17. It seems reasonable to regard Paryphella triquetra as a synonym of Cathaysia orbicularis Liao.

\section{Superfamily RICHTHOFENIOIDEA Waagen, 1885}

\section{Richthofeniid, genus and species undetermined} FIGURE 20(1-8)

Small. crateriform or squat cone-shape; apex pointed in one specimen; posterior side evenly rounded, arched, or flattened 
with a shallow furrow; interarea narrow and flat, occupying nearly entire length of pedicle valve; elytridium convex, narrow, occupying only $1 / 3$ of interarea; surface irregularly wrinkled.

STRATIGRAPHIC OCCURRENCE AND LOCALITY.-LONgdongchuan Formation: Xikou section, Zhenan County, Shaanxi Province.

COMPARISON.- These specimens from the Longdongchuan Formation of Shaanxi Province are somewhat similar to Richthofenia sinensis Waagen (1884:742, 743, pl. 82: fig. 4) from the middle division of Productus Limestone in the Salt Range, but the limited material does not permit us to judge that they are identical. They are externally comparable to specimens collected from Upper Pernian of Loping. Jiangxi Province, identified as Richthofenia lawrenciana Koninck by Kayser (in Richthofen, 1883:195-198, pl. 24: figs. 4, 5); however, they differ in that $R$. lawrenciana has strong rugae and distinct spine-scars. These specimens are closely similar to the specimen of Richthofenia guangdeensis Liao (1984:280, pl. 1: figs. 21-23), but, owing to the fact that no trace of myocoelidium was found in these specimens, there is insufficient evidence to assign these specimens to the genus Richthofenia.

\section{Order RHYNCHONELLIDA Kuhn, 1949}

\section{Superfamily Wellerelloidea Xu and Liu, 1983}

\section{Family WeLLERELLIDAE Likharev, 1956}

Genus Uncinunellina Grabau, 1932

\section{Uncinunellina multicostifera sp. nov.}

FIGURES 21. 22(1-27)

Medium size for genus; biconvex; transversely subovate, widest anterior to midlength; hinge slightly curved; sides rounded; commissure strongly uniplicate; costae beginning slightly anterior to beaks, crests low and slightly angular, becoming flattened toward margins, each crest bearing slight groove; interlocking spines visible in well-preserved specimens; costae increasing by bifurcation.

Pedicle valve slightly inflated; beak sinall; geniculated in a dorsal direction. curving to forn tongue with truncated or slightly curved anterior edge; sulcus shallow with flat or slightly round floor; 9-10 costae in sulcus, 12-14 costae on each side. Brachial valve strongly inflated, with short geniculation at anterior inargin, low fold beginning at anterior $1 / 3$, crest flattened or slightly arched, sometimes slightly depressed, bearing 10-11 costae, anterior-lateral inargin steeply declined toward ventral, with $12-15$ costae.

Pedicle valve interior with stout teeth; dental plates short, subparallel but wide apart. Brachial valve interior with shallow dental socket, inner socket ridge proportionately high and strong; hinge plates thin and separated; crural bases attached at

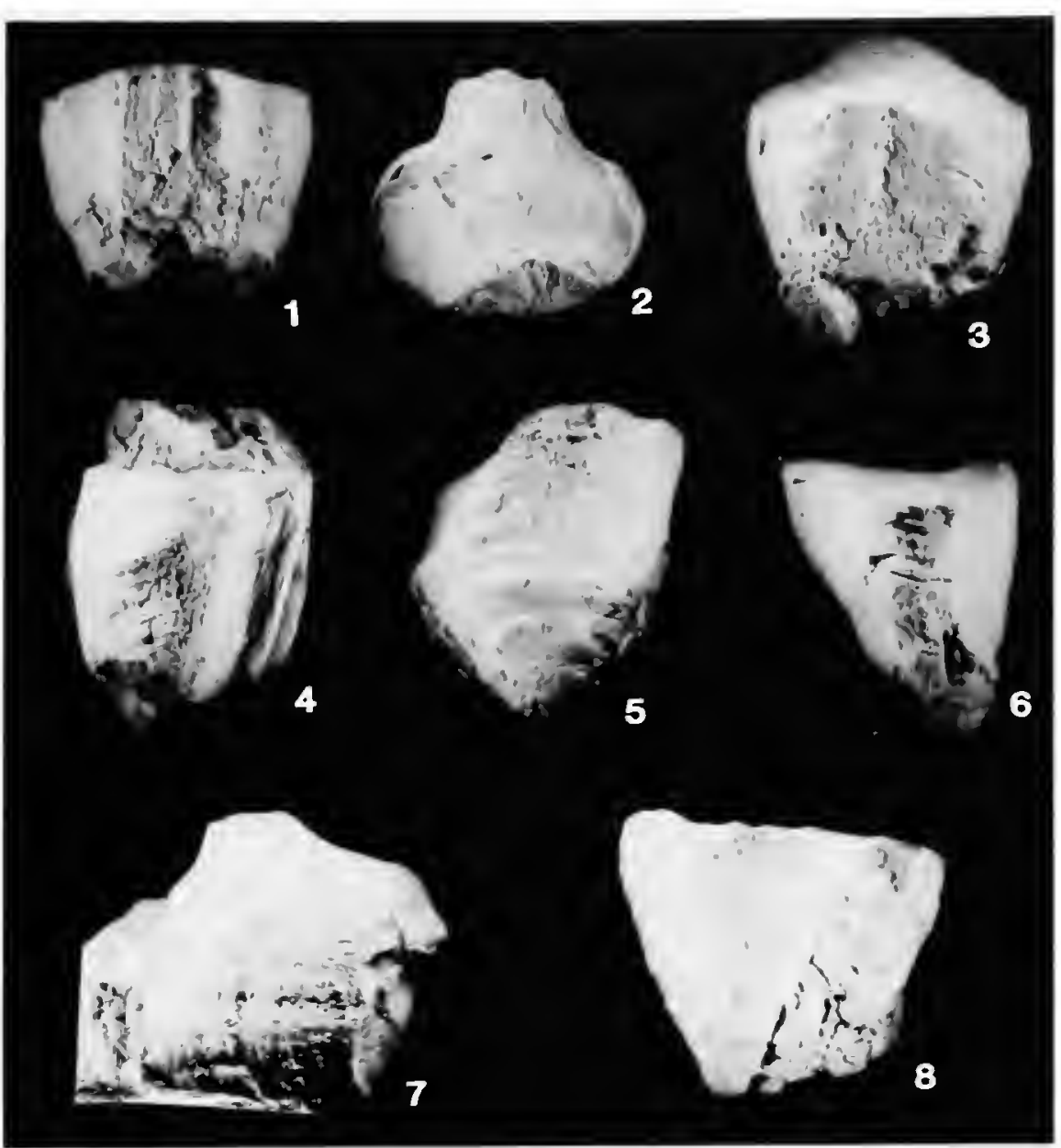

FIGURE 20.-Richthofeniid, genus and species undetermined: 1-3, 6, posterior transverse section, ventral, and lateral views $(\times 1)$, USNM 456049; 4, 7, lateral and ventral views ( $x 1)$, USNM 456050; and 5,8, ventral and lateral views $(x 1)$, USNM 456051, all from section 32.

insides of hinge plates, crescent-shape.

HOLOTYPE.-USNM 456052.

MEASUREMENTS (mm).-

\begin{tabular}{|c|c|c|c|c|c|c|c|}
\hline \multirow[b]{2}{*}{ USNM } & \multicolumn{2}{|c|}{ Pedicle valve } & \multicolumn{2}{|c|}{ Brachial valve } & \multirow{2}{*}{\multicolumn{2}{|c|}{$\begin{array}{l}\text { Thick- } \\
\text { th ness }\end{array}$}} & \multirow{2}{*}{$\begin{array}{c}\text { Ratio } \\
\text { (length } \\
\text { to width) }\end{array}$} \\
\hline & Length & $\begin{array}{l}\text { Curved } \\
\text { length }\end{array}$ & Length & $\begin{array}{l}\text { Curved } \\
\text { length }\end{array}$ & & & \\
\hline 456057 & $15.0 ?$ & 25.5 & 13.8 & 15.0 & 21.1 & 12.0 & 0.71 \\
\hline 456052 & 12.3 & 20.4 & 11.2 & 14.0 & 17.3 & 11.0 & 0.71 \\
\hline 456053 & 12.0 & 19.3 & 10.5 & 13.3 & 16.5 & 10.0 & 0.73 \\
\hline 456054 & 11.6 & 18.5 & 9.9 & 12.5 & 15.7 & 9.3 & 0.74 \\
\hline 456055 & $10.9 ?$ & 20.3 & 10.9 & 11.3 & 16.7 & 11.1 & 0.65 \\
\hline 456056 & 10.5 & 13.1 & & 15.6 & 14.9 & 9.8 & 0.70 \\
\hline
\end{tabular}

STRATIGRAPHIC OCCURRENCES AND LOCALITIES.Changxing Fornation: Huayingshan section, Linshui County, Sichuan Province; Beifengjing section, Zhongqing City; Beipei section, Zhongqing City, Sichuan Province; Shatian section, Huangshi City, Hubei Province; Huangzhishan section, Wuxing County, Zhejiang Province.

DiAGNOSIS.- Transverse subovate outline; $9-10$ costae in sulcus, more than 12 costae at each side, costate beginning near each beak.

COMPARISON.-The new species is similar to $U$. theobaldi Waagen (1883:425-427, pl. 34: fig. 1; Grant, 1976, pl. 48: figs. $1-9$ ) in outline and occurrence of multiple costae at the sides; it is different in that its costae begin on or near the beaks, and 


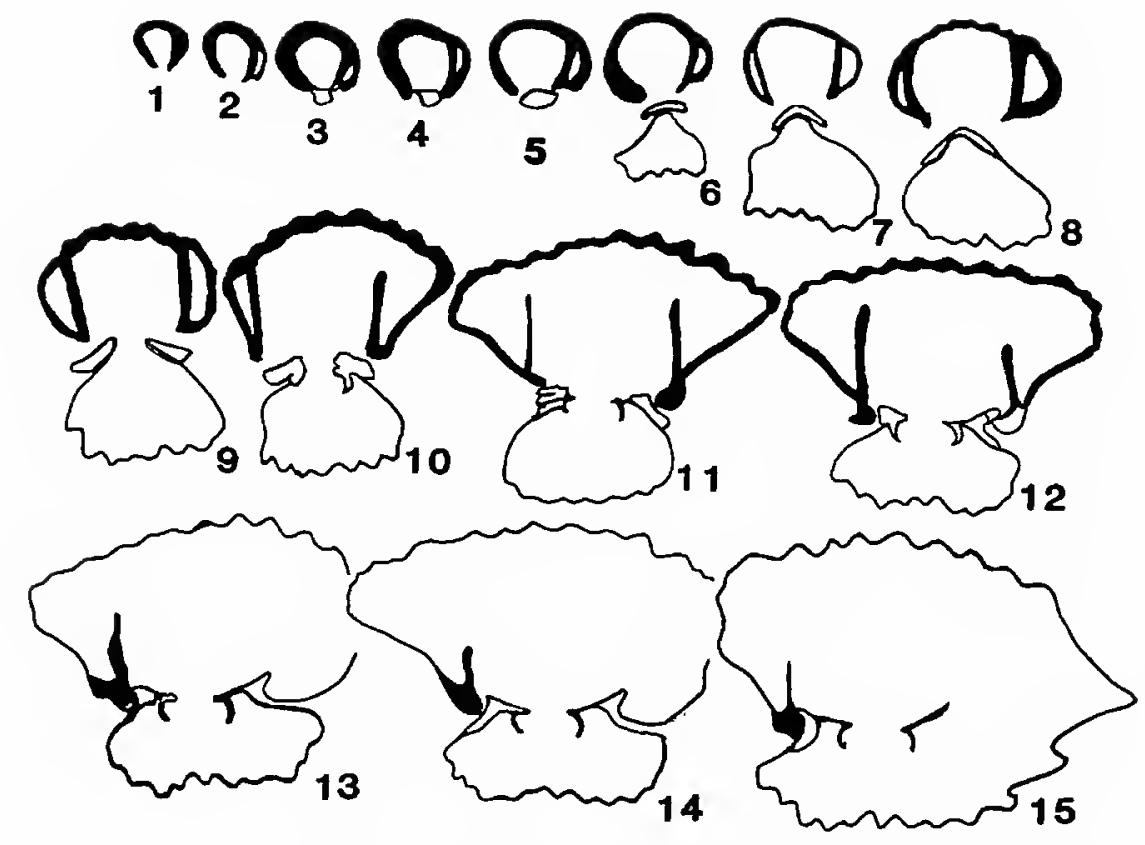

FIGURE 21.-Serial sections of Uncinunellina multicostifera, new species, showing the internal features.

there are more costae in the sulcus than on the fold. It differs from $U$. mitigata Grant (1976:179, 180, pl. 48: figs. 10-17) in its rather transverse outline, low fold, and costae beginning near the beaks. Internally, the dental plates of the new species are not fused to the valve wall, and the crural bases are crescentic. Uncinunellina mongolicus (Grabau, 1931:209-211, pl. 5: figs. 7, 8, pl. 6: figs. 3, 4) also has the costae beginning near the beaks, but this species is very small and subcircular, slightly transverse in outline, and its costae express the pattern of ten-seven-ten, or twenty-seven plications in all. The new species resembles $U$. wangenheimi (Pander) from the Maping limestone of Nantan, in Guizhou (Kweichow) Province, China, which was characterized by Grabau (1936:175-178, pl. 18: figs. 1,2) as having multiple costae and costae beginning near the beaks. That species, however, is large (shell length 16-19 $\mathrm{mm}$ ) and slightly narrower than the new species, and its ratio of shell length to width is $\sim 0.81-0.83$, which is much higher than the new species. Furthermore, Grabau (1936:178) recorded "two well-developed dental plates, somewhat converging toward the bottom of the valve," which obviously differs from the new species. Liao and Meng (1986:81, pl. 4: figs. 22-26) described $U$. tenuis, which has 9 costae in the sulcus and 10-11 costae on the sides and seemingly resembles the new species, but that species is small, with a thin coelomic cavity and simple costate (no bifurcations).

DisCUSSION.-Grant (1976:178) was the first to exhaustively investigate the structure of the genotype species, Uncinulus theobaldi Waagen, which proved Uncinunellina is an available genus. Internal features of specimens from South China, which are revealed in the serial sections, are consistent with specimens of the Salt Range. Wang et al. (1966), referring to Uncinunellina, wrote that the "median septum [is] straight and long" in the dorsal interior, but specimens of $U$. theobald $i$ from the Salt Range and $U$. multicostifera, the new species from South China, have not verified this feature. We did find, however, a low ridge in a specimen of the new species, which suggests that the genus had a median ridge whose presence depended upon the separation of the muscle scars.

Waagen (1883:425) recorded the presence of "very fine ribs which commence not very far from the apex of the valve" in the description of $U$. theobaldi, and this character was considered a proper feature of the genus by Grabau (1932:100), who wrote that "the plications ... may become obsolete in the earlier part of the shell." As Grant pointed out, the costae can be used to divide the genus into two groups: (1) species whose costae begin in the umbonal region, such as, $U$. theobaldi, $U$. mitigata, and $U$. jabiensis; and (2) those whose costae begin near the beaks, such as, $U$. mongolicus, $U$. wangenheimi, $U$. darwasica, and $U$. multicostifera, new species. Comparison of the internal structures of these two groups shows them to be quite comparable to each other, and externally, no radical feature separates them realistically into different genera.

ETYMOLOGY.-From the Latin, multi, meaning many, costi, meaning ribs, and fera, meaning bearing.

\section{Family PONTISIIDAE Cooper and Grant, 1976}

\section{Subfamily LISSORHYNCHIINAE Xu and Liu, 1983}

\section{Prelissorhynchia gen. nov.}

Small, subtriangular to subcircular; unequally biconvex, brachial valve more convex; pedicle beak suberect or slightly incurved; delthyrium opened or covered by short deltidial plates; anterior commissure strongly uniplicate; costae beginning at anterior $1 / 3$ or at midlength.

Pedicle valve interior with large, knob-like teeth; dental plates strong and subparallel extended. Brachial valve interior with undivided hinge plate, but hinge plates separating socket ridges and crural bases, inner hinge plates forming arched bridge; sockets shallow, socket ridges low; crura crescentic; median septum absent.

DIAGNOSIS.-Small semicostate, strongly uniplicate with deep indentation at anterior commissure; interior with subparallel dental plates and undivided arched hinge plate.

FIGURE 22 (opposite page).-1-27, Uncinunellina multicostifera, new species: $1-5$, dorsal, ventral, lateral, posterior, and anterior views $(\times 1)$, from section 8 , USNM 456053; 6-10, idem ( $\times 1$ ), USNM 456058; 11-15, idem $(\times 1)$, USNM 456057, all from section 6. 16-20, dorsal, ventral, lateral, posterior, and anterior views $(x 1), 22-26$, idem $(\times 2)$, and $21,27(\times 20.8)$, showing interlocking spines, USNM 456052, holotype, from section 27 . 28-48, Prelissorhynchia pseudoutah (Huang): 28, 29, and 32, dorsal, ventral, and anterior views, USNM 456059; 30, 31, lateral and anterior views, USNM $456060 ; 33,34,35$. and 42, dorsal, ventral, lateral, and anterior views, USNM 456065; 36-39, idem, USNM 456064a; 40, 41, 47, and 48, idem, USNM 456063; 43-46, idem, USNM 456064b; all $\times 3$, from section 9. 49-56, Prelissorhynchia triplicatioid, new species: 49-52, dorsal, ventral, lateral, and anterior views $(\times 2)$, USNM 456062, paratype, from section 9; 53-56, idem $(\times 3)$, USNM 456061, holotype, from section 6 . 


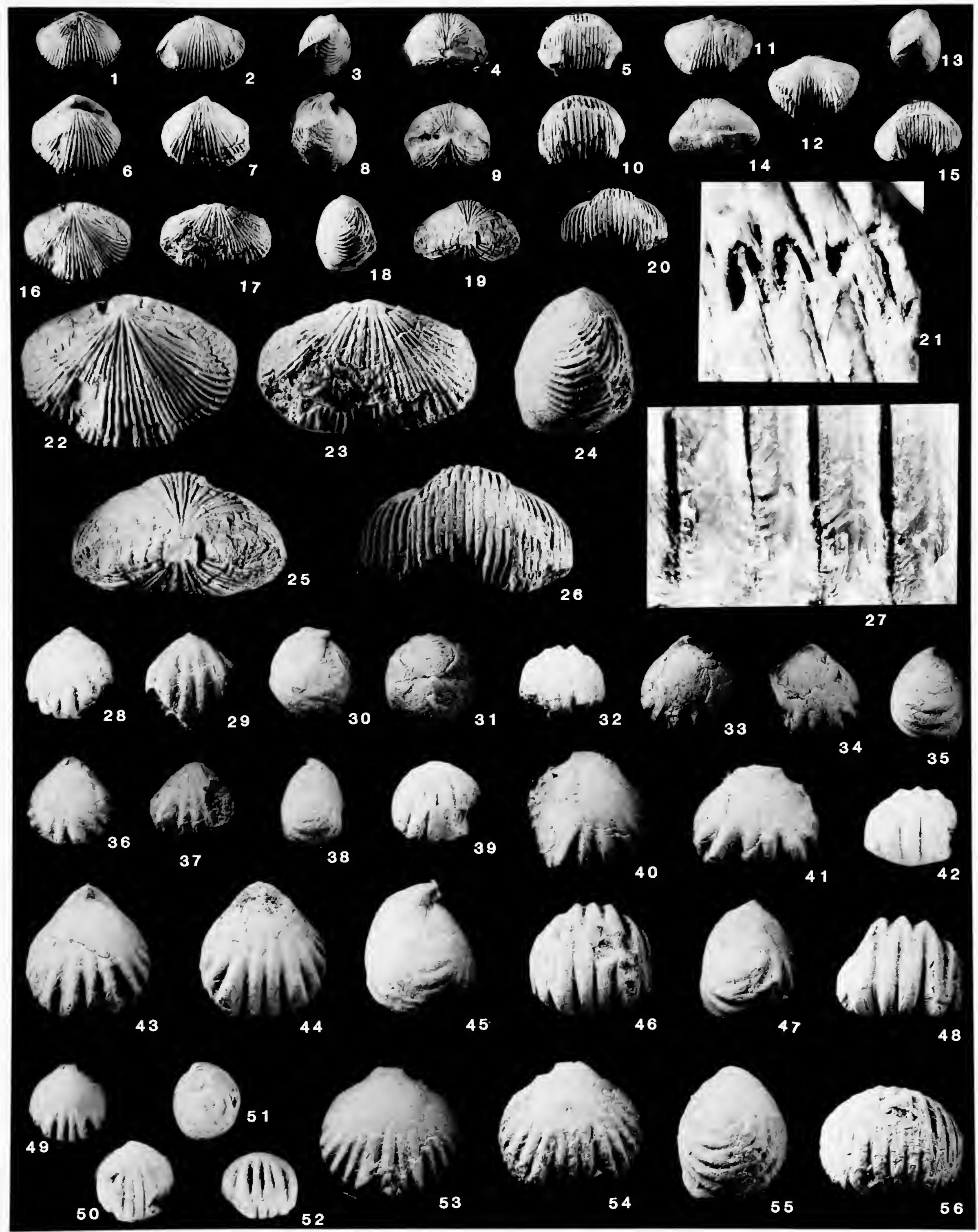


COMPARISON.-Internally, members of the new genus resemble Pontisia Cooper and Grant (1969:13; 1976a:2019) and Lissorhynchia Yang and Xu (1966:14, 94). Pontisia is triangular, somewhat less strongly inflated, its costae begin near the beaks, and it has an elongate-oval foramen. Lissorhynchia is parasulcate and has few plications near the anterior margin. The new genus has relatively long, crescentic crura but lacks median ridges in either valve; these may be the main bases for discrimination of this new genus.

TYPE SPECIES.-Pugnax pseudoutah Huang (1933:64-66, pl. 10: figs. 1-8).

ETYMOLOGY.-From the Latin, pre, meaning before; hence, before Lissorhynchia. The name is feminine.

\section{Prelissorhynchia pseudoutah (Huang, 1933), new combination}

FIGURES 22(28-48), 23

Pugnax pseudoutah Huang, 1933:64-66, pl. 10: Tigs. 1-8.-Wang, 1955b:134, pl. 73: figs. 13-16.-Wang et al., 1964:396, 397, pl. 66: figs. 12-15.-Hou et al., 1979:95. pl. 13: figs. 21. 22.

Neowellerella pseudoutah (Huang).-Liao, 1980a, pl. 7: figs. 38, 39.

Lissorhynchia pseudoutah (Huang).-Xu in Z.Y. Yang et al., 1987:229, pl. 13: figs. 15, 16, pl. 14: figs. 10, 12 .

DIAGNOSIS.--Small, subtriangular to subcircular, semicostate; sulcus and fold commencing from somewhat anterior to midlength; 2 costae in sulcus and 3 on fold, $2-3$ costae each lateral side.

MEASUREMENTS (mm).-

\begin{tabular}{|c|c|c|c|c|c|c|}
\hline \multirow[b]{2}{*}{ USNM } & \multicolumn{2}{|c|}{ Pedicle valve } & \multicolumn{2}{|c|}{ Brachial valve } & \multirow[b]{2}{*}{ Width } & \multirow[b]{2}{*}{$\begin{array}{c}\text { Thick- } \\
\text { ness }\end{array}$} \\
\hline & Length & $\begin{array}{l}\text { Curved } \\
\text { length }\end{array}$ & Length & $\begin{array}{l}\text { Curved } \\
\text { length }\end{array}$ & & \\
\hline 456064 & 9.2 & 12.0 & 7.0 & 7.9 & 8.7 & 7.8 \\
\hline 456063 & 8.1 & 11.9 & 6.9 & 7.4 & 8.1 & 6.6 \\
\hline 456059 & 7.9 & 11.3 & 7.1 & 7.6 & 7.0 & 6.7 \\
\hline 456065 & 6.5 & 7.8 & 4.4 & 5.9 & 6.3 & 4.5 \\
\hline 456060 & 6.3 & 9.0 & 5.4 & 6.5 & 6.0 & 4.8 \\
\hline
\end{tabular}

STRATIGRAPHIC OCCURRENCES AND LOCALITIES.Changxing Formation: Yutangjiao section, Jijiang section, Nantong County, Sichuan Province; Beipei section, Zhongqing City, Sichuan Province.

Discussion.-The description of internal features of the genus is based on specimens of $P$. pseudoutah from South China. These internal features clearly show that $P$. pseudoutah is not subordinate to Pugnax, which has separated hinge plates and crura supported by crural plates. Liao (1980a) regarded this species to be a member of the genus Neowellerella Dagys, a junior synonym of Lissorhynchia Yang and $\mathrm{Xu}$. Xu and Liu (in Z.Y. Yang et al., 1987) concurred with the placement of $P$. pseudourah in Neowellerella. Careful study, however, has found essentially the same distinctions mentioned in the "Comparison" section of the genus description, so it is reasonable to establish a new genus.

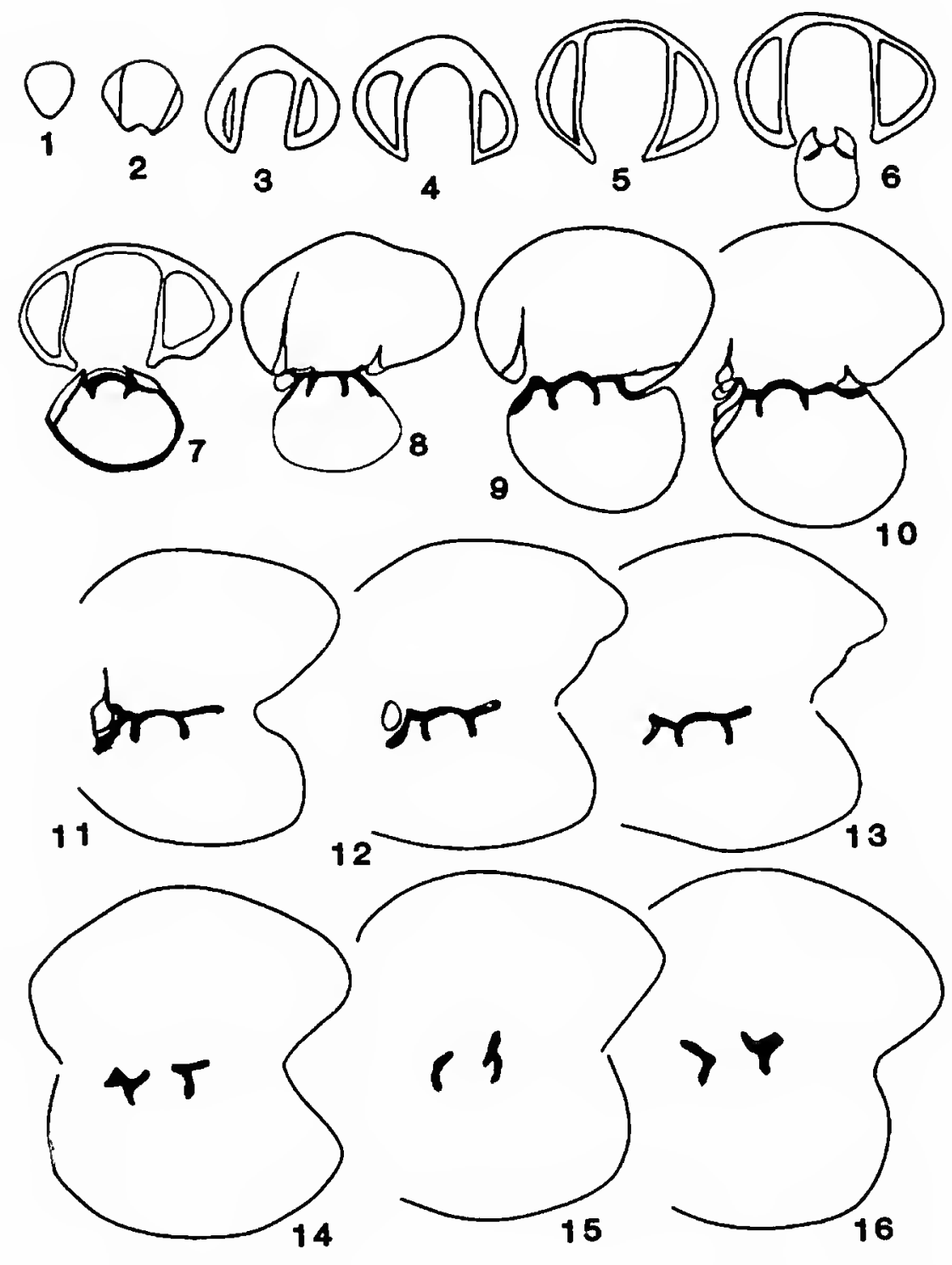

FIGURE 23.-Serial sections of Prelissorhynchia pseudoutah (Huang) showing intemal features.

\section{Prelissorhynchia triplicatioid sp. nov}

FIGURES 22(49-56), 24

Small size, unequally biconvex to subequally biconvex; subcircular or subglobular in outline; anterior commissure strongly uniplicate with sharp zigzag; surface semicostae beginning somewhat anterior to midvalves, crest of each costa slightly rounded, but subangular on fold, 4 costae on fold, 3 in sulcus, and 3-6 on flanks.

Pedicle valve gently convex with roundly turned-up tongue; sulcus originating somewhat anterior to midlength, shallow and moderately broad with reverse-trapezoid shape in transverse profile; beak suberect but often not preserved. Brachial valve strongly inflated with steeply turned-down lateral sides, fold low, only bare anterior edge dominated over flanks, with a short, roundly bent edge.

Pedicle valve interior with stout, knob-like teeth; dental plates subparallel. Brachial valve interior with shallow socket, inner-socket ridges low; hinge plate undivided, outer hinge plates proportionately wider, inner hinge plate arched; crura 


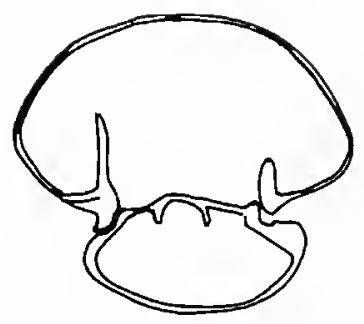

FIGURE 24.-A thin section of Prelissorhynchia triplicatioid, new species, showing the internal features.

crescent-shape.

HOLOTYPE.-USNM 456061.

MEASUREMENTS (mm).-

\begin{tabular}{ccccccccc} 
& \multicolumn{2}{c}{ Pedicle valve } & & \multicolumn{3}{c}{ Brachial valve } & & Thick- \\
\cline { 2 - 3 } \cline { 5 - 6 } USNM & & Curved & & Clurved & & Width & ness \\
456061 & 9.3 & 13.4 & & 8.7 & 10.5 & 9.2 & 7.2 \\
456063 & 7.5 & 7.8 & & 6.4 & 7.2 & 7.3 & 6.5
\end{tabular}

STRATIGRAPHIC OCCURRENCES AND LOCALITIES.-LOWE Changxing Formation: Huayingshan section, Linshui County and Yutangjiao section, Nantong County. Sichuan Province.

DIAGNOSIS.-Small, subcircular in outline, semicostate, 3 costae in sulcus, 4 on fold, and 3-6 on flanks.

COMPARISON.-Prelissorhynchia triplicalioid, new species, resembles $P$. pseudoulah in almost all internal features and in most external features, such as semicostae, low fold, sulcus beginning somewhat anterior to midvalve, and strongly uniplicate anterior commissure; it differs in its subcircular outline and more costae. "Wellerella" dorashamensis Sokolskaya (1965:233, pl. 40: fig. 7 ) is extemally similar to $P$. riplicalioid, but it has a flat undivided hinge plate with crural bases attaching at the sides of the hinge plate (Sokolskaya, 1965, text-fig. 37). Another species, "Neowellerella" triplicala Liao (1980a), with 3 costae in the sulcus, appears to be comparable to the new species, but this South China species has costae commencing from the "anterior of apex of shell" and has a "flat hinge plate" (Liao, 1980a:263, 264, pl. 8: figs. 18-20)); such features obviously differ from the new species.

ETYMOLOGY.-From the Latin, tri meaning three, plica meaning fold, and oid meaning like, similar.

\section{Superfamily Stenoscismatoidea Oehlert, 1887 (1883)}

Family AT RIBONIIDAE Grant, 1965

\section{Subfamily ATrIBONIINAE Grant, 1965}

\section{Genus Cyrolexis Grant, 1965}

\section{Cyrolexis antearcus sp. nov.}

FIGURES 25, 26(1-20)

Sinall. moderately biconvex. subcircular or transversely subovate; thickest near anterior margin; commissure strongly uniplicate; semicostate, costae high and sharp at anterior margin, numbering 2-3 on fold, 1-2 in sulcus, and 2-4 at each side.

Pedicle valve slightly or moderately convex in lateral profile, anterior profile flattened or gently arched; beak short, suberect, sharply pointed; sulcus originating from midvalve, widening forward, tongue bent upward, anterior edge truncated. Brachial valve moderately or strongly convex, fold elevated over flanks.

Pedicle valve interior with small hinge teeth; dental plates thin, converging to form deep spondylium, supported by low septum duplex, sessile in extreme apex, spondylium extending anteriorly about $1 / 3$ valve length. Brachial valve interior with knob-like cardinal process, becoming comb-like at top of hinge plate; hinge plate undivided, outer hinge plates flat and relatively wide, inner hinge plate narrow, slightly arched; camarophorium beginning in apex, extending about $1 / 4$ valve length, supported by high median septum duplex, fairly small and narrow, its lateral edges directly connected to crura that attach between inner and outer hinge plates; intercamarophorial plate short but visible near beak.

SYNTYPES.-USNM 456066, 456067.

MEASUREMENTS $(\mathrm{mm})$.-

\begin{tabular}{|c|c|c|c|c|c|c|}
\hline \multirow[b]{2}{*}{ USNM } & \multicolumn{2}{|c|}{ Pedicle valve } & \multicolumn{2}{|c|}{ Brachial valve } & \multirow[b]{2}{*}{ Width } & \multirow[b]{2}{*}{$\begin{array}{c}\text { Thick } \\
\text { ness }\end{array}$} \\
\hline & Length & $\begin{array}{l}\text { Curved } \\
\text { length }\end{array}$ & Length & $\begin{array}{l}\text { Curved } \\
\text { length }\end{array}$ & & \\
\hline 456065 & 9.3 & 15.5 & 8.3 & 11.0 & 8.7 & 7.9 \\
\hline 456066 & 7.4 & 11.3 & 6.2 & 6.5 & 8.0 & 4.8 \\
\hline 456067 & $6.8 ?$ & $9.6 ?$ & 6.5 & 6.8 & 8.4 & 5.2 \\
\hline
\end{tabular}

STRATIGRAPHIC OCCURRENCES AND LOCALITIES.Changxing Formation: Huangzhishan section, Wuxing County, Zhejiang Province; Yutangjiao section, Nantong County, Hunan Province; Huayingshan section, Linshui county, Sichuan Province.

DIAGNOS1S.-Small, maximum thickness near anterior edge; strongly uniplicate anterior commissure; usually 2-3 costae on fold and each flank.

COMPARISON.-Cyrolexis antearcus, new species, resembles $C$. beccojeclus (see below) in its semicostae and suberect and pointed beak; it differs in its high and sharp costae, only 1-2 costae in the sulcus, and rather obviously elevated fold. It is readily distinguishable from $C$. haquei Grant (1965:91-95, pl. 6: fig. 1-5) in its stronger costae, rather wide sulcus, and small camarophorium.

ETYMOLOGY.-From the Latin, ante, meaning before, and arcus, meaning curve.

\section{Cyrolexis beccojectus sp. nov.}

FIGURE 27(1-12)

Small, strongly or moderately biconvex; outline subglobular, young individuals subtriangular, shell thick in umbonal region; anterior commissure uniplicate; costae low, originating at 

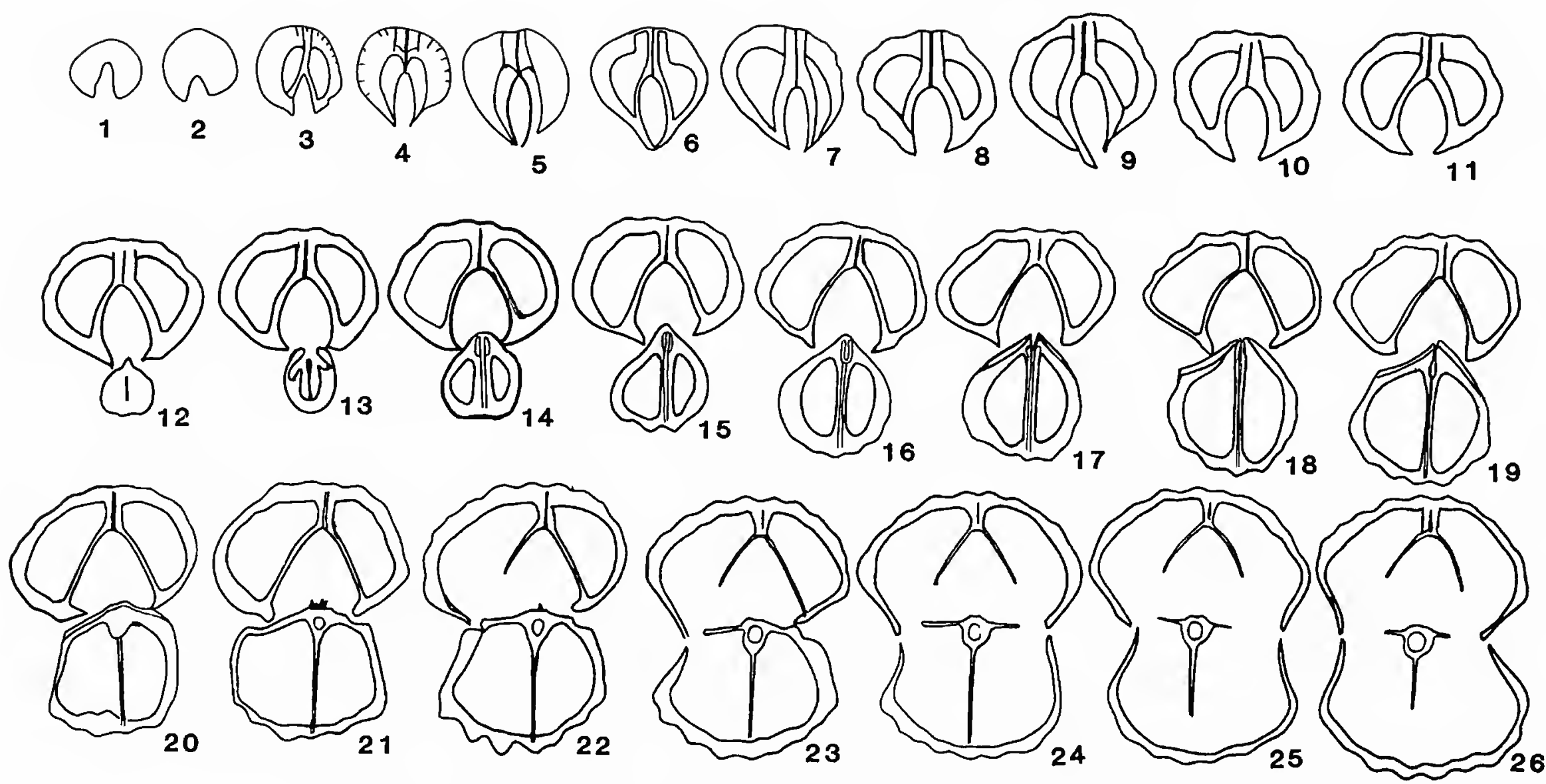

FIGURE 25.-Serial sections of Cyrolexis antearcus, new species, showing interior features.

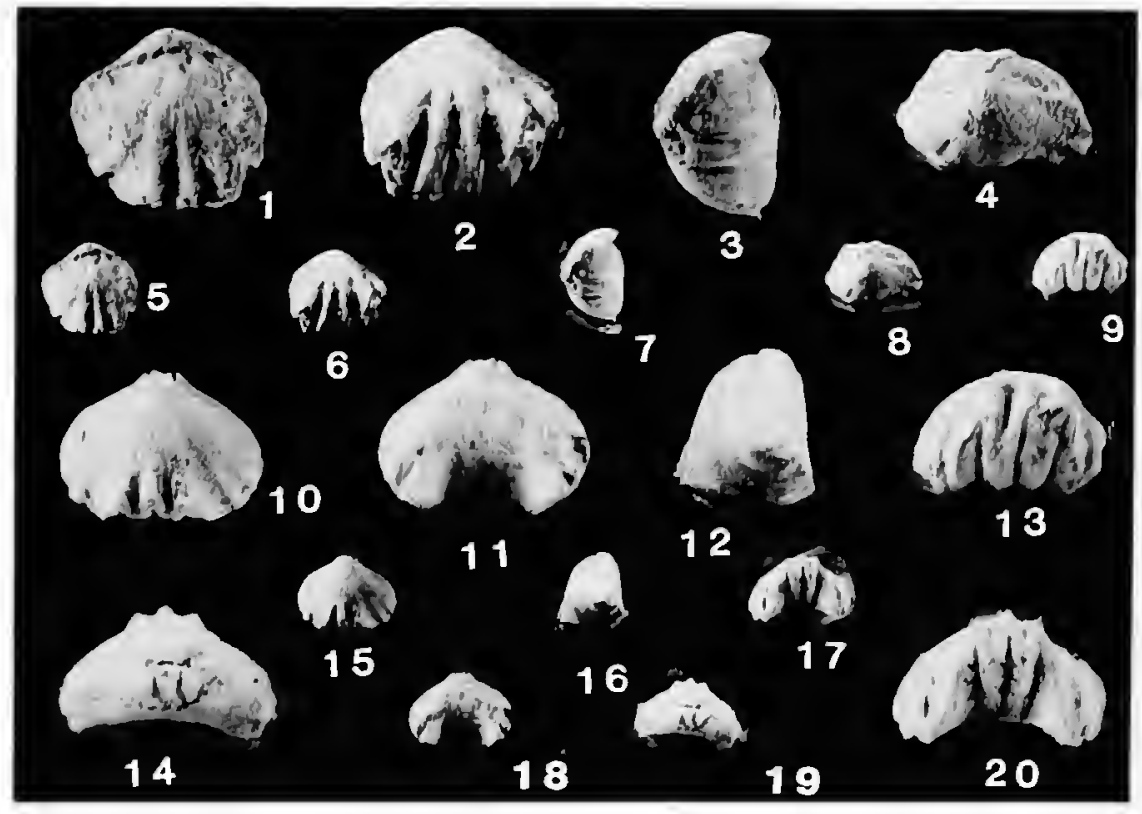

FIGURE 26.-Cyrolexis antearcus, new species: 1-4, $13(\times 2)$ and 5-9 $(\times 1)$, dorsal, ventral, lateral, posterior, and anterior views, from section 27, USNM 456066, syntype; 10-12,14, $20(\times 2)$ and 15-19 (×1), idem, from section 6, USNM 456067, syntype. (Reduced to $971 / 2 \%$ for publication.)

midvalve, crests rounded at origin, becoming sharp toward anterior, numbering 4-5 on fold, 3-4 in sulcus, and 4-5 on each flank; no stolidium preserved.

Pedicle valve moderately convex; beak small, pointed, suberect; delthyrium opened; sulcus beginning near midlength, shallow, about $1 / 3$ shell width, forming tongue roundly bent dorsally. Brachial valve more strongly convex; beak small, incurved; fold low, beginning at midvalve, elevated over flanks near anterior margin, anterior flanks turned down steeply.

Pedicle valve interior with deep spondylium.

HOLOTYPE.-USNM 456142.

MEASUREMENTS (mm).-

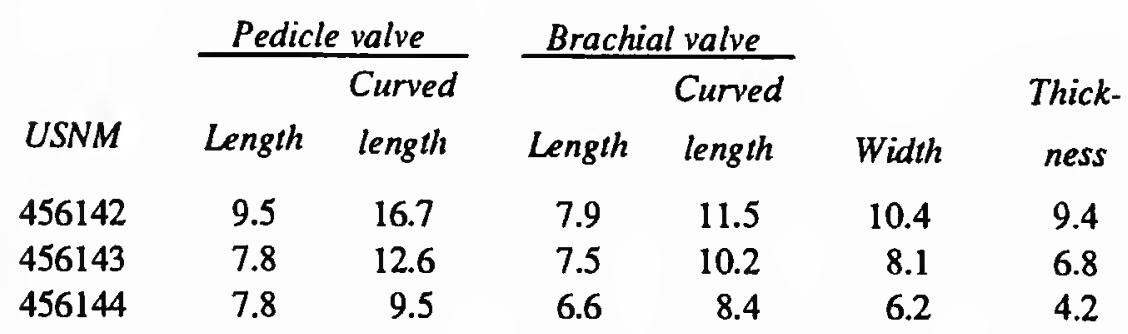

STRATIGRAPHIC OCCURRENCES AND LOCALITIES.Changxing Formation: Huangzhishan section, Wuxing County, Zhejian Province. Longdongchuan Formation: Xikou section, Zhenan County, Shaanxi Province.

DIAGNOSIS. - Small, subglobular; uniplicate anterior commissure; beak small and suberect; usually 4-5 costae on fold and each flank.

COMPARISON.-Cyrolexis beccojectus, new species, is similar to $C$. haquei Grant (1965:91-95, pl. 6: figs. 1-5) from the Salt Range in most interior and exterior features. They differ in that the new species is wider in juvenile stages and thicker in mature stages, has more costae, and has a smaller camaro- 


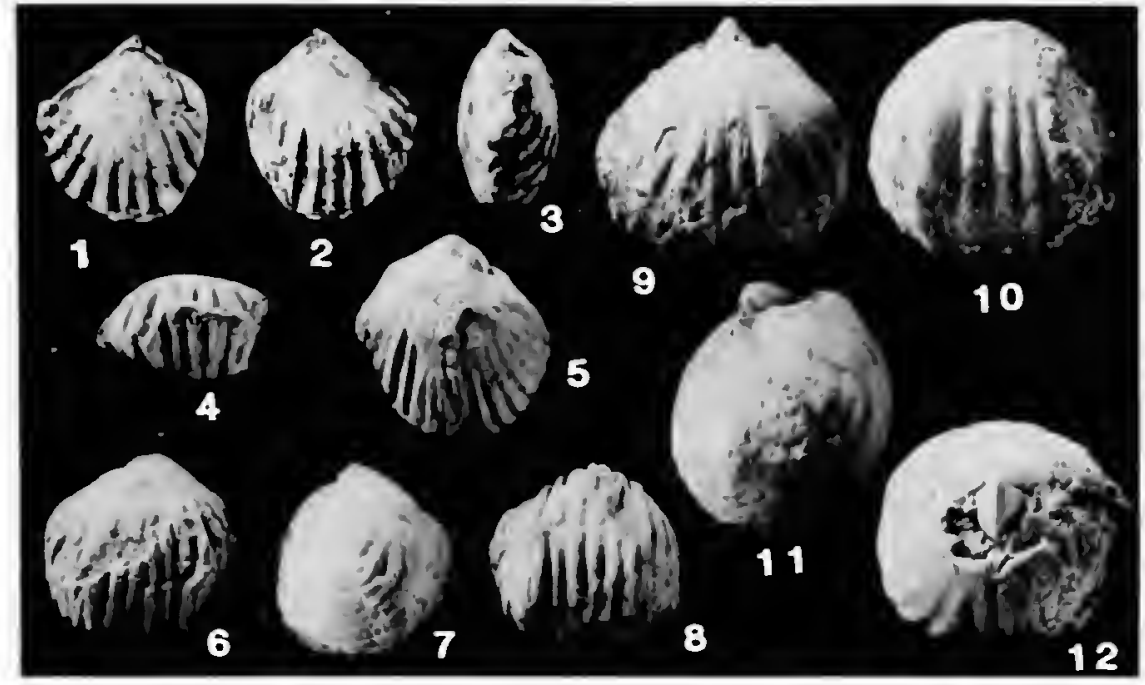

FIGURE 27.-Cyrolexis beccojectus. new species: 1-4, dorsal, ventral, lateral, and anterior views $(\times 2)$, USNM 456143; 5-8, idem $(\times 2)$, USNM 456144, both from section 32. 9-12, dorsal, ventral, lateral, and posterior views $(\times 2)$, from section 27, USNM 456142, holotype. (Reduced to $971 / 2 \%$ for publication.)

phorium. It resembles $C$. ussuricum (Maslennikov) (Koczyrkevicz, 1979:57-59, pl. 13: figs. 3-20) in such respects as small size, greatest width and thickness near midlength, sulcus shallow and beginning near midlength, and big $U$-shape spondylium, but $C$. ussuricum usually is more elongate with costae originating somewhat anterior to midvalve, and internally it has a deeper hinge socket and lower septum duplex.

ETYMOLOGY.-From the Latin, becco, meaning beak, and jectus, meaning cast down (referring to the curved beak).

\section{Order SPIRIFERIDA Waagen, 1883}

Suborder SPIRIFERIDINA Waagen, 1883

Superfamily SPIRIFEROIDEA King, 1846

Family SPIRIFERIDAE King, 1846

Subfamily NEOSPIRIFERINAE Waterhouse, 1968

\section{Genus Cartorhium Cooper and Grant, 1976}

\section{Cartorhium xikouensis sp. nov.}

FIGURES 28, 29(1-8)

Small size for genus; moderately biconvex; subcircular in outline, widest near midlength, hinge line short, extremities rounded; commissure uniplicate; costae arranged in fascicles without plication of shell, asymmetrical bifurcation, numbering about 2 or 3 bifurcations per fascicle, total numbering about 20-27 per valve; concentric growth laminae weak, irregularly spaced.

Pedicle valve with maximum convexity about half way between beak and midvalve; beak moderately curved; interarea triangular, relatively small, curved sharply near beak but

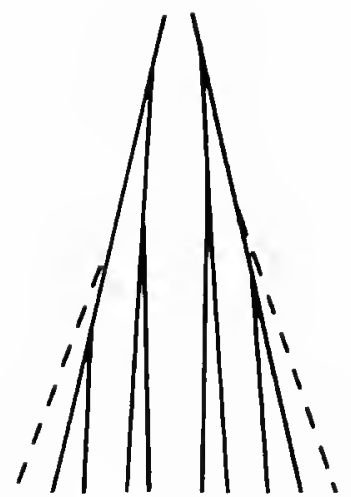

FIGURE 28.-The costellar formula for the sulcus of Cartorhium xikouensis, new species, is shown; dashed lines represent lateral branches out of the sulcus.

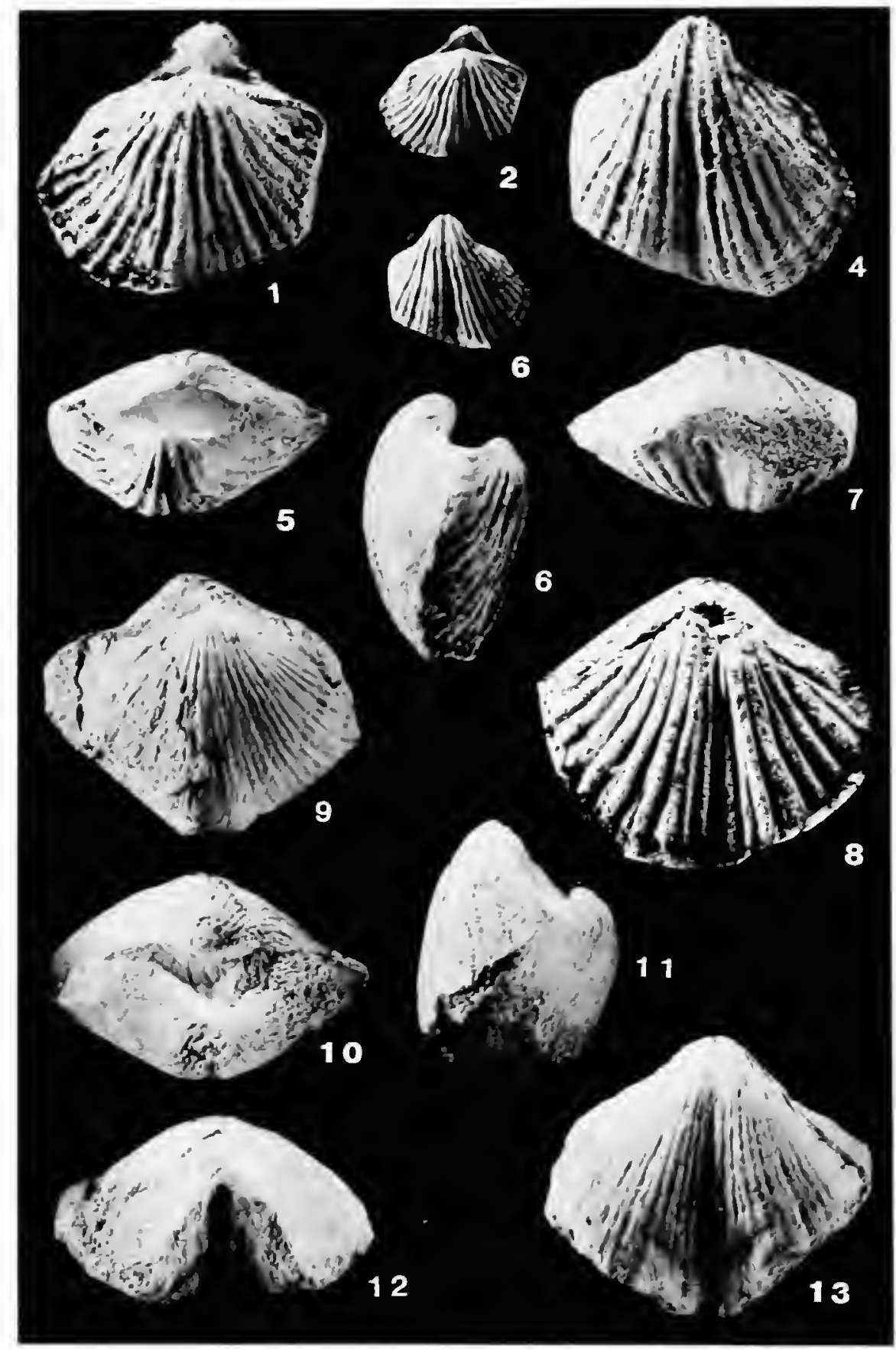

FIGURE 29.-Cartorhium Cooper and Grant. 1-8, Cartorhium xikouensis, new species: $1,4-7$, dorsal, ventral, posterior, lateral, and anterior views $(\times 2)$; $2,3$, dorsal and ventral views ( $\times 1)$, from section 32, USNM 456145, holotype. 8 , ventral view $(x 2)$, from section 15 , USNM 456146. 9-13, Cartorhium twifurcifer, new species: dorsal, posterior, lateral, anterior, and ventral views $(\times 1)$, from section 32, USNM 456147, holotype. 


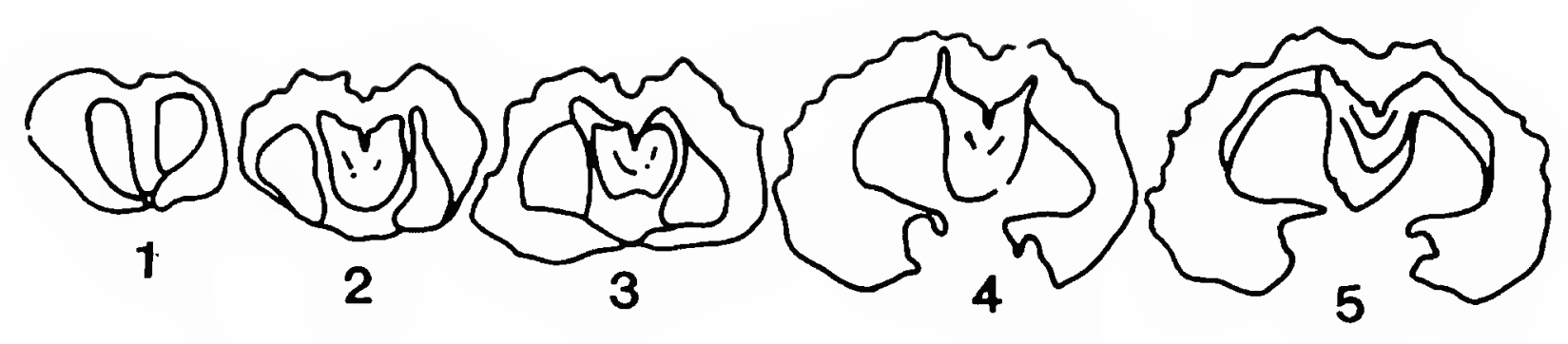

FIGURE 30.-Serial sections of Cartorhium twifurcifer, new species, showing the internal features of the pedicle valve.

flattened anteriorly; delthyrium proportionately large, open; sulcus shallow, bisected by median groove, bounded by original costa beginning from beak on cach side, bifurcated asymmetrically forward, forming fascicle. Brachial valve less strongly convex; beak suberect; fold low, an original costa beginning from beak extending along fastigium, forming fascicle forward having 5 costae at anterior margin. Internal features unknown.

HOLOTYPE.-USNM 456145.

MEASUREMENTS (mm).-

\begin{tabular}{|c|c|c|c|c|c|c|c|}
\hline \multirow[b]{2}{*}{ ISNM } & \multicolumn{2}{|c|}{ Pedicle valve } & \multicolumn{2}{|c|}{ Brachial valve } & \multirow[b]{2}{*}{ Width } & \multirow[b]{2}{*}{$\begin{array}{l}\text { Hinge } \\
\text { width }\end{array}$} & \multirow[b]{2}{*}{$\begin{array}{c}\text { Thick } \\
\text { ness }\end{array}$} \\
\hline & Length & $\begin{array}{l}\text { Curved } \\
\text { length }\end{array}$ & Length & $\begin{array}{l}\text { Curved } \\
\text { length }\end{array}$ & & & \\
\hline & 14.5 & 20.2 & 17.1 & 18.2 & 9.7 & $15.5 ?$ & 8.6 \\
\hline
\end{tabular}

STRATIGRAPHIC OCCURRENCES AND LOCALITIES.Longdongchuan Formation: Xikou section, Zhenan County, Shaanxi Province. Paoshui Formation: Paoshui section, Laibin County, Guangxi Province.

DIAGNOSIS.-Small Cartorhium, low fold has one fascicle, shallow sulcus has two fascicles.

COMPARISON.-Cartorhium xikouensis, new species, differs from West Texas species described by Cooper and Grant (1976a) by its small size and subcircular outline, but it somewhat resembles juveniles of some species, for instance, $C$. larum (R.E. King), $C$. chelomatum Cooper and Grant, $C$. relusum Cooper and Grant, and $C$. orbiculatum Cooper and Grant. Carlorhium latum (Cooper and Grant, 1976a:21952197, pl. 615: figs. 1-33, pl. 616: figs. 1-23, pl. 624: figs. 1-10) has a rounded outline and low fold, so that the new species is similar to juveniles of that species, but $C$. xikouensis juveniles have somewhat thicker costac or low plications and only a few incipient bifurcations on the lateral slopes. Cartorhium retusum (Cooper and Grant, 1976a:2200, 2201, pl. 617: figs. 21-26, pl. 618: figs. 1-29). C. chelomatum (Cooper and Grant, 1976:2192, 2193, pl. 613: figs. 1-35), and $C$. orbiculatum (Cooper and Grant, 1976:2198-2200, pl. 617: figs. 1-20) all have transverse outlines and rather coarse costae in juveniles; thus. they are readily distinguishable from the new species.

ETYMOLOGY.-From the Latin suffix, -ensis, meaning occurring at the Xikou section.

\section{Cartorhium twifurcifer sp. nov.}

FIGURES 29(9-13), 30, 31

Medium size, strongly biconvex; transversely subelliptical in outline, hinge line shorter than greatest width, near midlength; anterior commissure uniplicate, not plicated laterally, weakly emarginate; costae fine, asymmetrical bifurcation, poorly fasciculate, total numbering about 46-52 per valve, most bifurcation in posterior area; growth laminae irregularly spaced, especially near anterior margin.

Pedicle valve with strongly convex, semipyramidal shape; beak suberect; interarea triangular, moderately long, slightly curved, apsacline but almost catacline; delthyrium proportionately large, open; sulcus roundly $V$-shape, forming broad tongue gently bent dorsally, median groove beginning from beak. Brachial valve somewhat less strongly convex; beak slightly incurved; fold rounded, prominent near anterior commissure, no definite boundary at posterior part.

Pedicle valve interior with short apical plates, almost parallel to one another, limited at beak area; median ridge fine, filling callosity between apical plates in apical cone, forming strong pseudoseptum; posterior part of valve thickened. Brachial valve interior features unknown.

HOL.OTYPE.-USNM 456147.

MEASUREMENTS (mm).-

\begin{tabular}{|c|c|c|c|c|c|c|c|}
\hline \multirow[b]{2}{*}{ USNM } & \multicolumn{2}{|c|}{ Pedicle valve } & \multicolumn{2}{|c|}{ Brachial valve } & \multicolumn{3}{|c|}{ Mid- } \\
\hline & Length & $\begin{array}{l}\text { Curved } \\
\text { length }\end{array}$ & Length & $\begin{array}{l}\text { Curved } \\
\text { length }\end{array}$ & $\begin{array}{l}\text { Hinge } \\
\text { width }\end{array}$ & $\begin{array}{l}\text { length } \\
\text { width }\end{array}$ & $\begin{array}{c}\text { Thick- } \\
\text { ness }\end{array}$ \\
\hline 5614 & 29.3 & 38.2 & 23.4 & 28.8 & $26.9 ?$ & $35.0 ?$ & 20.1 \\
\hline
\end{tabular}

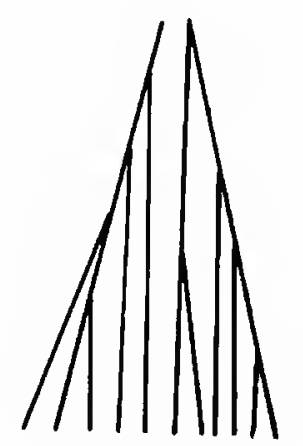

FIGURE 31.-A diagram showing the costellar formula in the sulcus of Cartorhium mifurcifer. new species. 
STRATIGRAPHIC OCCURRENCE AND LOCALITY.-Longdongchuan Formation: Xikou section, Zhenan County, Shaanxi Province.

DIAGNOSIS.-Transversely subelliptical Cartorhium with high, near catacline interarea and broad, anterior tongue of sulcus large.

COMPARISON.-Cartorhium twifurcifer, new species, is similar to Semibrachythyrina fasciculatus Yang (in Yang et al., 1962:104, 105, pl. 42: figs. 8-10) in that both have fasciculate costae that begin at the posterior and range about the same in number, but the new species has short apical plates in the pedicle valve, a relatively short hinge, and a prominent fold and sulcus. Those differences are the reasons to put the new species into Cartorhium. Semibrachythyrina anshunensis Liao (1980a:264, pl. 7: figs. 29-34) and S. ziyunensis Feng (in Feng and Jiang. 1978:287, 288, pl. 103: figs. 2a-e) resemble the new species somewhat in ornamentation, but both of them have low or narrow interareas, a low acute angle between the interarea and commissural plane, and no apical plates. Spirifer mahaensis Huang (1933:41-43, pl. 6: figs. 1-3) has a high and near catacline interarea, but the relatively wide hinge and median costa in the sulcus make it easy to distinguish from the new species.

ETYMOLOGY.-Latinized from Anglo-Saxon, twi, meaning two, and from the Latin, furcifer, meaning fork-bearing.

\section{Superfamily CyRTIOIDEA Frederiks, 1924}

\section{Family A MBocoeliIDAE George, 1931}

\section{Genus Crurithyris George, 1931}

\section{Crurithyris pusilla Chan, 1979}

FIGURES 32, 34(1-47, 52)

Crurithyris pusilla Chan in Hou et al., 1979:96, 97, pl. 13: figs. 24-26.

Paracrurithyris pigmaea (Liao), 1979:202. pl. 1: figs. 4-7.-Liao in Zhao et al., 1981:54. pl. 8: fig. 6.

Crurillyris pigmaea Liao, 1980a:264, pl. 8: figs. 1-4.

Medium size for genus, nearly planoconvex; outline nearly subelliptical to semielliptical, usually transverse, greatest width near midlength; narrow sulcus on pedicle valve, very shallow or undeveloped, but brachial valve without fold, anterior margin broadly rounded, anterior commissure rectimarginate; surface of most specimens sinooth with a few fine growth lines, well-preserved specimens with regular concentric laminae closely spaced; minute bumps over surface considered scars of broken spines.

Pedicle valve strongly convex, semipyramidal; beak short. pointed or slightly swollen, slightly incurved; interarea moderatcly high, flatly concave; delthyrium narrowly triangular, open, lateral flanges low. Brachial valve slightly convex at posterior. flatter at anterior; beak small. notothyrium rather low and relatively narrowly triangular.
Pedicle valve interior with pedicle collar or vestigial delthyrium plates near apex of delthyrial cavity; hinge teeth knob-like, sturdy, dental ridges proportionately low and short, decreasing in thickness toward anterior; muscle scars elongate, visible when shell decorticated.

Brachial valve interior with shallow dental sockets with obscured socket ridges; cardinal process tuberculate, between socket walls; complete hinge plate thin, short; crura rod-like, crural plates thin, reaching to floor, nearly parallel, only slightly divergent, extending $1 / 3$ of length of shell, strongly divergent rising from floor toward inside; spiralia flattened, ribbon-like, including 6 loops on each side, axes of coiling directed slightly obliquely posteriorly toward point of greatest shell width; elongated diductor scars between crural plates, weakly impressed, separated by rather low and obscure median ridge.

\section{MEASUREMENTS (mm).-}

\begin{tabular}{|c|c|c|c|c|c|c|c|}
\hline \multirow[b]{2}{*}{ USNM } & \multicolumn{2}{|c|}{ Pedicle valve } & \multicolumn{2}{|c|}{ Brachial valve } & \multirow[b]{2}{*}{ Width } & \multirow[b]{2}{*}{$\begin{array}{l}\text { Hinge } \\
\text { widlh }\end{array}$} & \multirow[b]{2}{*}{$\begin{array}{c}\text { Thick- } \\
\text { ness }\end{array}$} \\
\hline & Length & $\begin{array}{l}\text { Curved } \\
\text { length }\end{array}$ & Length & $\begin{array}{l}\text { Curved } \\
\text { length }\end{array}$ & & & \\
\hline 456148 & 7.5 & 9.7 & 5.0 & 5.1 & 6.5 & 5.4 & 4.6 \\
\hline 456149 & 6.0 & 8.2 & 5.2 & 5.5 & 6.5 & 5.2 & 3.8 \\
\hline 456150 & 5.7 & 7.5 & 4.8 & 4.9 & 5.5 & $4.6 ?$ & 3.5 \\
\hline 456151 & 5.4 & 6.8 & 4.5 & 4.6 & 5.5 & 5.6 & 3.1 \\
\hline 456152 & 4.4 & 5.9 & 3.8 & 4.2 & 4.6 & 3.6 & 2.7 \\
\hline 456154 & 3.8 & & 3.2 & & 4.3 & 3.0 & 2.3 \\
\hline 070404 & 3.1 & & 2.9 & & 3.6 & 3.0 & 2.0 \\
\hline
\end{tabular}

STRATIGRAPHIC OCCURRENCES AND LOCALITIES.Changxing Formation and lowest part of Feixianguan Formation: Huayingshan section, Linshui County; Shangsi section, Guanfyuan County; Beipei section, Zhongqing City; Yanjingxi section, Hechuan County, Sichuan Province; Huangzhishan section, Wuxing County, Zhejiang Province. Lower Xikou Formation: Yading section, Zhuangping County, Fujian Province.

DIAGNOSIS.-Medium size, near planoconvex, interarea relatively high, narrow median sulcus trace on pedicle valve usually visible.

COMPARISON.-Crurithyris pusilla Chan is similar to $C$. urei (Fleming) and C. amoena George (1931:45, 55, pl. 5: figs. 5, 6, pl. 4: figs. 1-4) in its size and outline, but the latter two species have sulci on both valves whereas $C$. pusilla has a narrow and very shallow median sulcus only on the pedicle valve. It most nearly resembles $C$. longirostris Cooper and Grant, particularly in its wide interarea; however, it differs in the fact that the West Texas species has no sulcus on the pedicle valve. It is comparable to $C$. sulcata Stehli in size, profile, and interarea, but $C$. sulcala has sulci on both valves and has an emarginate anterior. The species $C$. speciosa Wang (1955b:146, pl. 83: figs. 1-4; Wang et al., 1964:546, pl. 104: figs. 13-16) (Figure 33), which has a relatively large size, brilliant concentric lines. hairy spines, and no sulcus on the pedicle valve, is easy to discriminate from $C$. pusilla. 


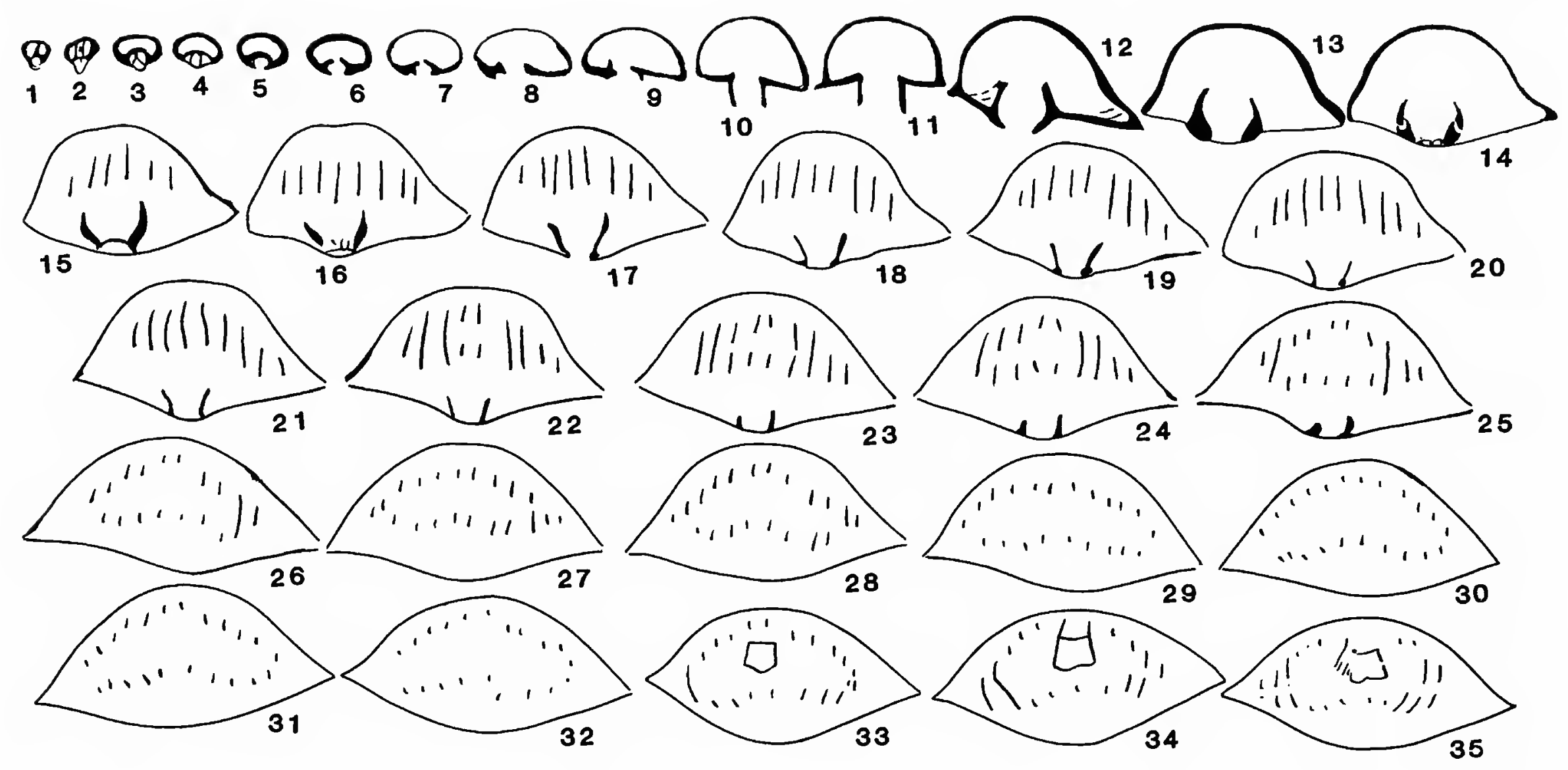

FIGURE 32.-Serial sections of Crurithyris pusilla Chan showing the internal features.
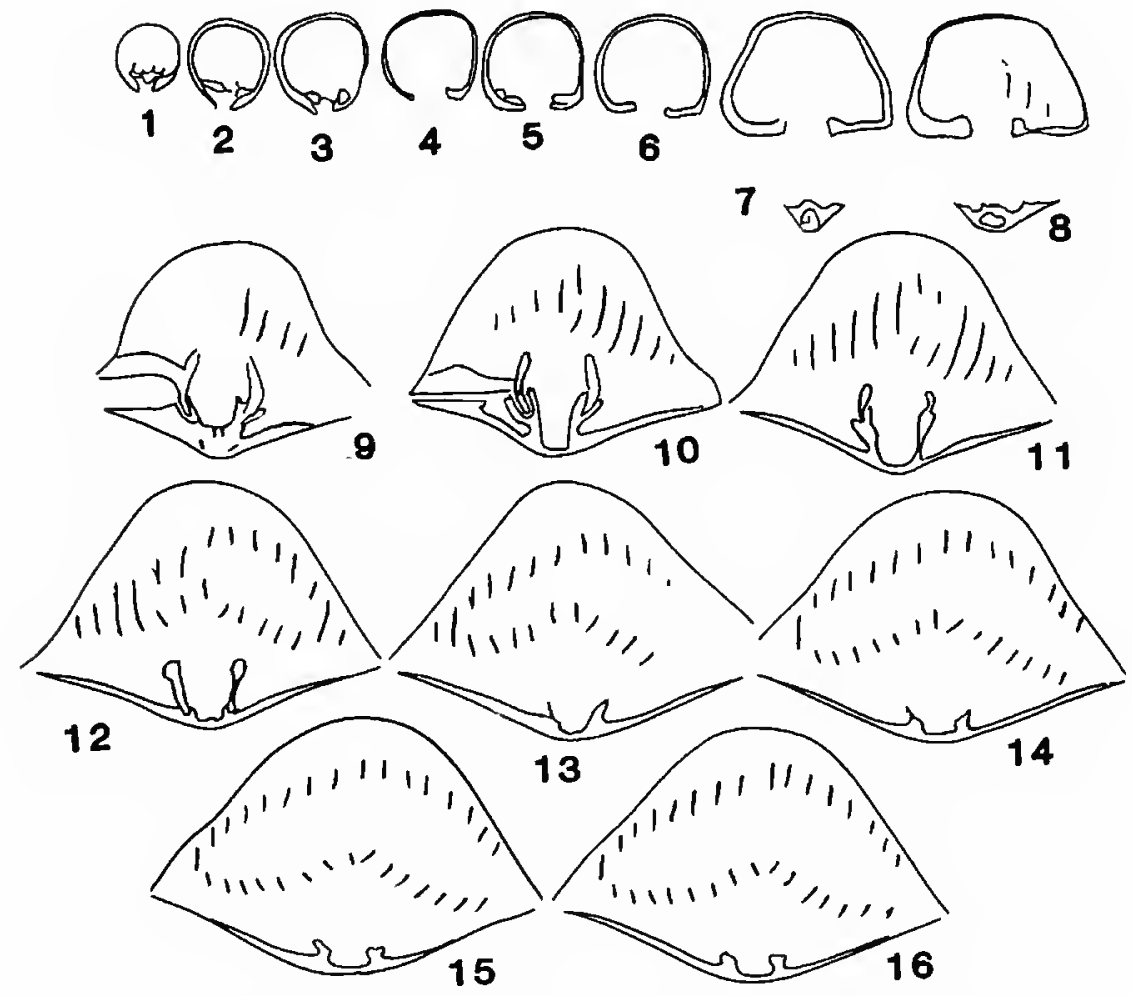

FIGURE 33. Serial sections of Crurithyris speciosa Wang showing the internal features.

DISCUSSION.-Chan described this species in September 1979 (in Hou et al., 1979). Liao (1980a) described a species named $C$. pigmaea at almost the same time. Comparing Liao's description and figures (1980a:264, pl. 8: figs. 1-4) with Chan's (1979:96, pl. 13: figs. 24-26) leads to the conclusion that $C$. pigmaea Liao is a synonym of $C$. pusilla Chan; therefore, the name of $C$. pigmae $a$ should be abolished because it was published later. Actually, Liao published an earlier paper in September 1979 (Liao, 1979, pl. 1: figs. 4-7) in which he presented illustrations of a species that he named Paracrurithyris pigmaea, but he did not give a description of the species. Paracrurithyris as a new genus was not described by Liao until 1981 (Liao in J.K. Zhao et al., 1981) at which time he also designated $C$. pigmaea as the type species. He also compared Paracrurithyris with Crurithyris George, stating that "externally and in the pedicle valve this genus resembles Crurithyris George (1931), but the brachial valve has fundamental differences" (Liao, 1981:86). The following is a translation of his Chinese description: "COMPARISON: In its external shape and internal structures, it is similar to Crurithyris George (1931), but it is distinguished by the latter's lack of closely spaced concentric laminae, undeveloped muscle scars, and crural plates that reach to the floor and are parallel" (Liao, 1981:54). According to the features of the topotype, C. urei (Fleming) has "narrow elongate posterior muscle-impressions" in the ventral valve, and "the cavities of the crural plates...and the obliquely-sloping antero-lateral margins of the hinge-plate" (George, 1931:59, pl. 4: fig. 2a) should be understood as crural plates. These two features, of course, are the proper features of the genus Crurithyris because $C$. urei is the type species of the genus. Concerning the ornamentation of the shell, only spines were noted by George, but he pointed out that the spines were closely packed in irregular concentric rows on the dorsal valve 


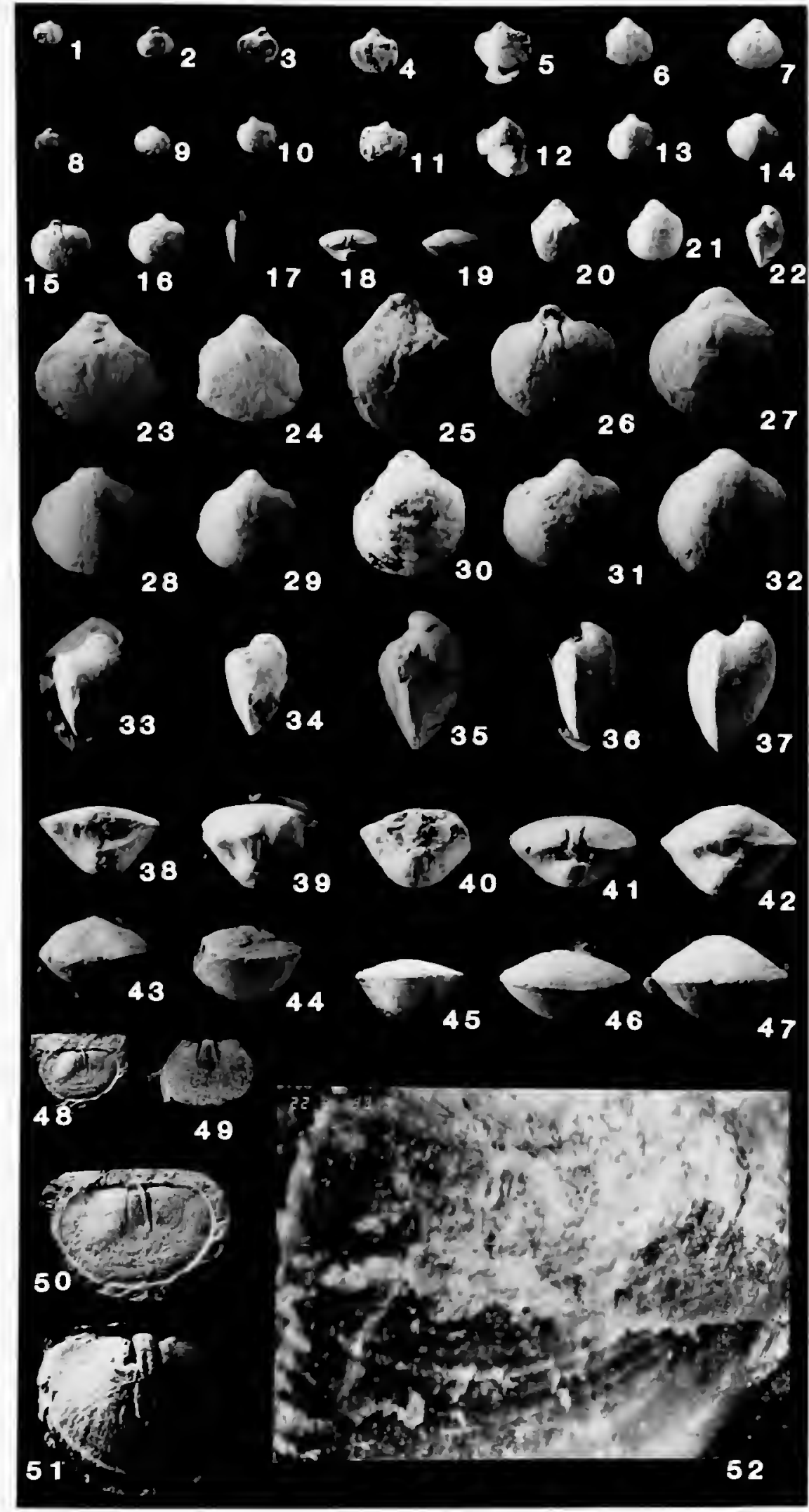

FIGUIRE 34.-Crurithyris. 1-47, 52, Crurithyris pusilla Chan: 1, 8, ventral and dorsal views $(x 1)$, USNM 456151a: 2,9 , dorsal and ventral views $(x 1)$, USNM $45615 \mathrm{lb}$ : 3. 10, idem ( $\times 1)$, USNM 456152; 4, 11, idem $(\times 1)$, USNM 456153; 5, 12, idem $(\times 1)$, USNM 456154; all from section 7. 6, 13, dorsal and ventral views $(\times 1), 24,29,34,39,44$, dorsal, ventral, lateral, posterior, and anterior views $(x 3)$, USNM 456148; 7, 14, dorsal and ventral views $(x 1), 23$, $28,33,38,43$, dorsal, ventral, lateral, posterior, and anterior views $(\times 3), 52$, micro-omamentation $(\times 20.8)$, USNM 456149; all from section 8. 15-19, dorsal, ventral, lateral, posterior, and anterior views $(\times 1)$, and $26,31,36,41,46$, idem ( $\times 3$ ), USNM 456155, from section 30. 20-22, dorsal, ventral, and lateral views $(x 1)$, and $25,30,35,40,45$, dorsal, ventral, lateral, posterior, and anterior views ( $\times 3$ ), USNM 456150, from section $27.27,32,37,42,47$, dorsal, ventral, lateral, posterior, and anterior views $(\times 3)$, USNM 456156, from section 6. 48-51. Crurithyris speciosa Wang: $48,50(\times 1, \times 2)$. USNM 456217; 49, 51 $(\times 1, \times 2)$, USNM 456157 , both from section 27 . (Reduced to $971 / 2 \%$ for publication.)
(1931:55). Cooper and Grant (1976a) described this genus in detail, including a thorough examination of the exposed internal structures. They provided the following description: "growth lines fine, closely spaced, visible only on wellpreserved surfaces; growth laminae weak, irregularly spaced" (1976:2121). Examination of specimen USNM 100418 of $C$. urei (Fleming), which is from Wetton, Staffordshire, England (Accession 153400), revealed that regular growth laminae are visible on the pedicle valve and this feature is comparable with specimens of South China. The internal structures of $C$. pusilla that we revealed by making serial sections (Figure 32) is completely consistent with silicified specimens from West Texas. Considering this resemblance, we include the species $C$. pusilla in the genus Crurithyris. Jing and Sun (1981:157) suggested setting up a new genus named Speciothyris and assigned $C$. speciosa Wang as the type species of the new genus, but the serial sections of Crurithyris speciosa Wang (Figure 33; see also Jing and Sun, 1981:156, text-fig. 17) are essentially similar to the serial sections of $C$. pusilla Chan (Figure 32).

\section{Suborder SPIRIFERINIDINA Cooper and Grant, 1976 \\ Superfamily SPIRIFERINOIDEA Davidson, 1884}

Family Paraspiriferinidae Cooper and Grant, 1976

Genus Paraspiriferina Reed, 1944

Paraspiriferina alpha (Huang, 1933)

FIGURES 35, 36(1-23)

Spiriferina multiplicata mut. alpha Huang, 1933:56-61, pl. 9: figs. 2, 3. Puncrospirifer alphetus (Huang).-Wang, 1955b:164, pl. 97: figs. 5-8.-Wang et al., 1964:584, 585, pl. 113: figs. 8-11.—Liao, 1980a:277, pl. 8: fig. 49. Crenispirifer alpheus (Huang).-Yang et al., 1987:233, pl. 15: figs. 26-28.

Shell small to medium for genus, moderately or strongly biconvex; outline subelliptical, hinge line shorter than maximum width, located between midlength and hinge line; hinge extremities rounded; costae moderately high, rounded, beginning at beaks, numbering 3-5 on each side of both valves; fold obviously larger than costae; sulcus sub-V-shape, limited costae much stronger than others.

Ventral valve interior with stout, knob-like teeth; dental plates moderately thick, extending only over length of delthyrium chamber, slightly convergent ventrally, adminicula thin, short; median septum long, extending forward nearly $2 / 3$ valve length, thick at posterior $1 / 2$, then becoming very thin at anterior $1 / 2$, almost same height for full length, braced against small apical plate coalescing with dental plates at umbonal region. Brachial valve interior with shallow hinge sockets formed by socket plates and partly roofed; inner-socket ridges small and low; crural plates very large, bow-like, attached from socket ridges; adminicula short, limited to umbonal region; crura extending forward from dorsally lowest part of crura 


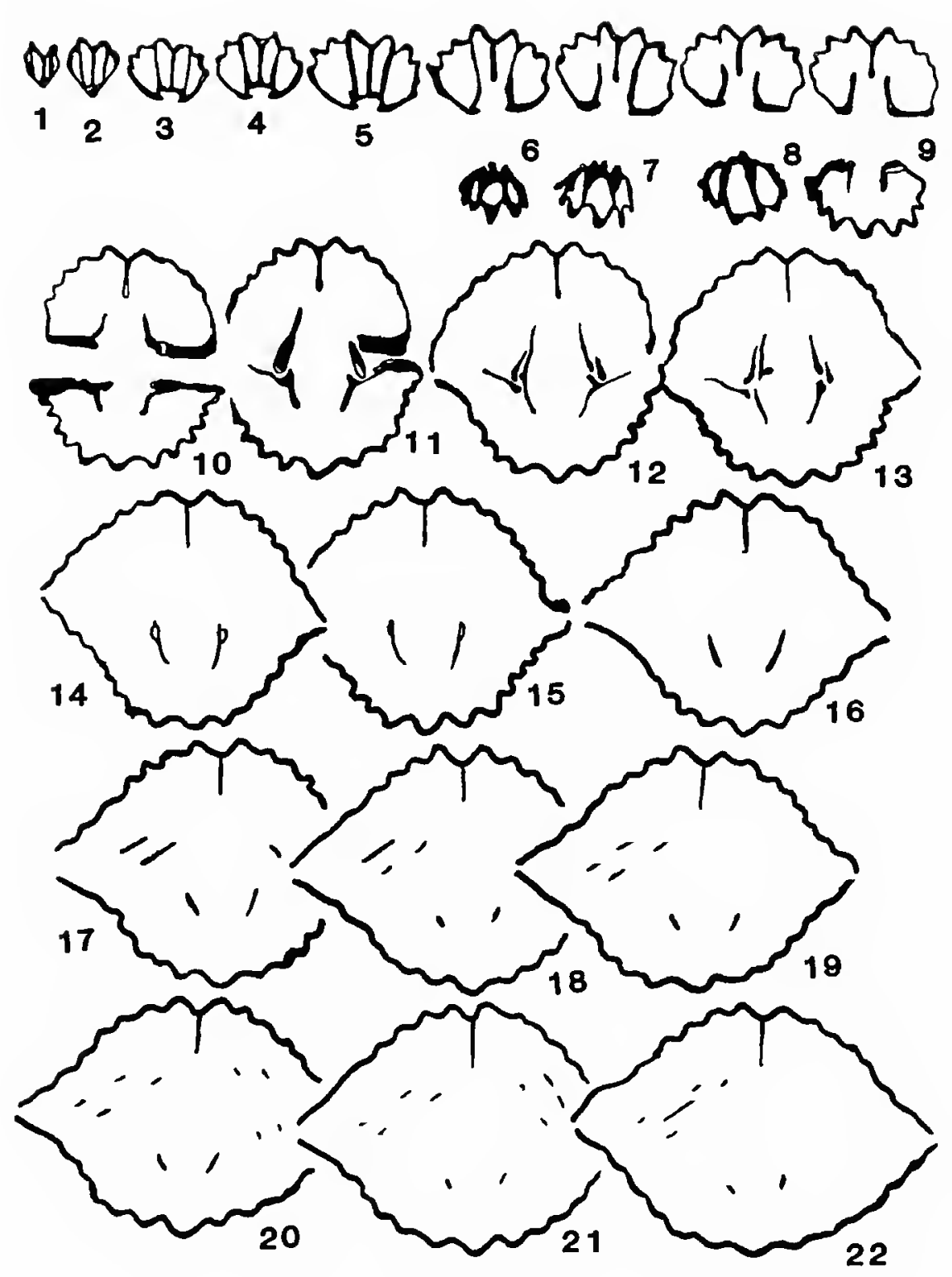

FIGURE 35.-Serial sections of Paraspiriferina alpha (Huang) showing the intemal features.

plates; spiralia with only $2-3$ coils at each side; cardinal process single, knot-like; low, thin, median ridge bisecting muscle area.

MEASUREMENTS (mm).-

$\begin{array}{cccccc}\text { Pedicle } & \begin{array}{c}\text { Brachial } \\ \text { valve } \\ \text { length }\end{array} & \begin{array}{c}\text { Marimum } \\ \text { length }\end{array} & \begin{array}{c}\text { Hinge } \\ \text { uidth }\end{array} & \text { uidth } & \text { Thickness } \\ \text { USNM } & 8.2 & 6.7 & 12.3 & 11.3 & 7.8 \\ 456158 & 6.9 & 5.5 & 8.2 & 6.7 & 6.1 \\ 456159 & 6.3 & 5.6 & 5.5 & 5.1 & 4.4 ? \\ 456160 & 5.2 ? & - & 9.2 & 5.5 & \\ 456161 & 6.1 & - & 9.8 & 6.9 & \\ 456162 & & & & \end{array}$

STRATIGRAPHIC OCCURRENCES AND LOCALITIES.-Longlan Formation and Changxing Formation: Langfengya section, Zhongqing City, Sichuan Province; Huangzhishan section, Wuxing County, Zhejiang Province. Paoshui Formation: Paoshui section, Laibin County, Guangxi Province.

COMPARISON.-Paraspiriferina alpha (Huang) is similar to $P$. gentilis Grant (1976:236, pl. 64: figs. 1-36) in its small size, general outline, and number of costae; it differs from the Thailand species in the fact that the South China species has a more strongly incurved beak, sub- $V$-shape sulcus, and moderately high costae. Because the specimens of South China are not silicified, the growth laminae are not well preserved, but their traces are still observable. In contrast, $P$. gentilis Grant has prominent, regularly spaced growth laminae, which seems to be the most important difference between these species.

In Waagen's (1883:502) description of Spiriferina multiplicata Sowerby (1829), he wrote that "on each side of the sinus are mostly four, sometimes six folds" and that it has rounded costae and a short hinge line. Those features are rather similar to Paraspiriferina alpha (Huang) except that Waagen's specimen is large and has a "broad, not deep and rounded," sinus (Waagen, 1883:502).

Paraspiriferina amoena Cooper and Grant (1976:2730, 2731, pl. 720: figs. 1-35) has a subelliptical outline and a few rounded costae, which resembles $P$. alpha, but it is distinguished by its shallow sulcus with flattened trough, low costae, and relatively short median septum.

DISCUSSION.-This species was assigned to Punctospirifer by many Chinese scientists (see synonymy) based on its spiriferinid shape. When studied in detail, Huang's species differs radically from any species of that genus. According to North (1920) who erected the genus, Punctospirifer is characterized by its wide hinge, wide and shallow mesial sinus, greater number of costae, and large spiral coils with jugum $(1920: 212,213)$. The South China species has a narrow hinge line, few costae, and only 2-3 spiral coils per side. Fine hair-like spines and traces of growth laminae are visible in well-preserved specimens. On the basis of growth laminae, nearly angular costae, and sub-V-shape sulcus, this species has been considered a species of Crenispirifer (Yang et al., 1987:233, pl. 15: figs. 26-28). Actually, the costae of this species are not really angular when compared to West Texas specimens. The internal features revealed by serial sections (Figure 34) show that this species is properly attributed to the genus Paraspiriferina.

Grant (1976:236) first described the internal details of a species of Paraspiriferina ( $P$. gentilis Grant), and Cooper and Grant (1976b:2729-2741) verified that many species of the genus have essentially the same internal features. Paraspiriferina alpha (Huang) has a long (more than $1 / 2$ valve length) median seplum braced by small apical plates and short adminicula in the ventral valve, and broad blade-like crural plates, a small cardinal process, and a low thin median ridge in the dorsal valve. These internal features, with the addition of the external features mentioned, combine to place this species in Paraspiriferina.

Huang (1933) originaly described the species as a mutation of Spiriferina multiplicata Sowerby and designated it by the Greek letter alpha. Wang (1955b) first correctly promoted it to an independent species discriminable from "multiplicata" by its small size, subrhombical outline, and 4 costae on each side (1955b:164; 1964:585). Some specimens collected from South China really have 5 costae on one side and 4 costae on the other 


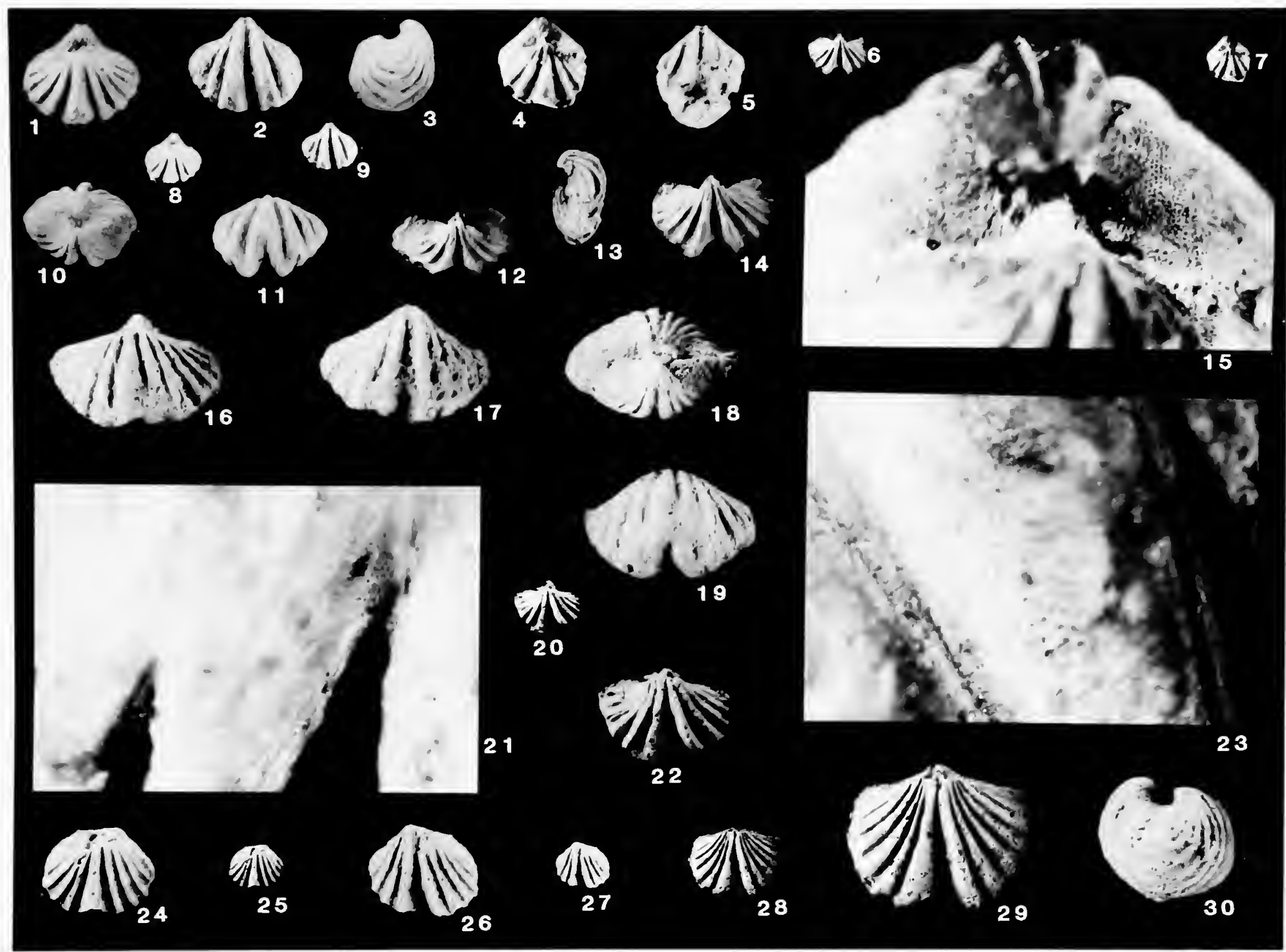

FIGURE 36.-1-23. Paraspiriferina alpha (Huang): 1-3, 10,11, dorsal, ventral. lateral, posterior, and anterior views $(\times 2)$, and 8,9, dorsal and ventral views $(x 1)$, USNM 456158: 16-19, dorsal, ventral, posterior, and anterior views $(\times 2)$, and 21, 23, micro-omamentation ( $\times 20.8)$. USNM 456159:4, 5, 13, dorsal, ventral, and lateral views ( $\times 2)$ : 7. dorsal view $(x 1)$ : and 15, micro-omamentation $(\times 20.8)$, USNM 456160; all from section 27. 6, ventral view ( $\times 1)$ : 12, 14, posterior and ventral views $(\times 2)$, USNM 456161: 20, 22, ventral views $(\times 1, \times 2)$, USNM 456162: all from section 16. 24-30, Callispirina? rotundella, new species: 24, 26 and 25, 27, dorsal and ventral views $(\times 2, \times 1)$, USNM 456163a, holotype: 30, lateral view $(\times 2)$, USNM 456163b, both from section 27. 28, 29. ventral view $(\times 1, \times 2)$, LSNM 456164. from section 6 .

(Figure 36(1, 16); Wang et al.. 1964, pl. 113: fig. 6). Therefore, we hereby emend the definition of this species and will discuss the difference between "multiplicata" and "alpha" below.

\section{Genus Callispirina Cooper and Muir-Wood, 1951}

\section{Callispirina? rotundella sp. nov.}

FIGURE 36(24-30)

Spirifer mulliplicata Sowemy, 1829:119.

Trigonotreta inultiplicata (Sowerby).-King, 1850:129.

Spiriferina inultiplicata (Sowerby).-Davıdson, 1858:19. pl. 1: figs. 38. 39. 45.
46.-Huang. 1933:57-59, pl. 9: figs. 4, 5.

Punctospirifer multiplicata (Huang).-Wang et al., 1964:584, pl. 113: figs. 12 , 13.

Spiriferellina inultiplicata (Huang).-Wou et al., 1979:97, pl. 12: fig. 14.

DiAGNOSIS.-Small size; subelliptical outline, slightly transverse, hinge line shorter than greatest width; profile bulbous; costae beginning at beaks, simple, high, angular, numbering 10-14; interspaces narrower than costae; sulcus deep with $V$-shape floor; fine growth lines, stronger growth laminae present at irregular intervals. Pedicle valve interior with high and long median septum reaching more than $1 / 2$ length of valve.

LECTOTYPE.-USNM 456163. 
STRATIGRAPHIC OCCURRENCES AND LOCALITIES.Changxing Formation: Huayingshan section, Linshui County, Sichuan Province; Huangzhishan section Wuxing County, Zhejiang Province; and other places of South China.

COMPARISON.-This species resembles Callispirina austrina Grant (1976:231-235, pl. 63: figs. 1-37) and $C$. rotunda Cooper and Grant (1976b:2743, pl. 705: figs. 66-82) in its high, angular costae and deep V-shape sulcus. But $C$. austrina has well-developed grow th laminae, relatively wide interspaces of costae, and a proportionately shorter median septum in the pedicle valve. Callispirina rorunda has a long median septum reaching to midvalve in the pedicle valve and relatively narrow interspaces of costae. Those features are more closely similar to $C$. rotundella; however, $C$. rotunda has a proportionately wide hinge line, more transverse outline, and wider fold.

Discussion.--Specimens collected from (1) Zunyi County (Tsunyihsien), Guizhou Province and Huayingshan section, Sichuan Province, described by Huang (1933) as Spiriferina multiplicata (Sowerby), (2) Hechuan section, Sichuan Province, identified by Wang et al. (1964) as Punclospirifer multiplicata (Sowerby), and (3) Lianxian section, Guangdong Province, reported by Hou et al. (1979) as Spiriferellina multiplicata (Sowerby), are straightforwardly identical with our specimens collected from Huayingshan section, Sichuan Province and Huangzhishan section, Zhejiang Province. But why not use the name "multiplicata"? The main reason is that the South China specimens do not correspond with the original definition of the species.

King (1850) first described and illustrated two specimens from England as Trigonotreta multiplicata, which corresponds to Spirifer multiplicala, the name given by Sowerby (1829, see Davidson, 1858:19). He described the species as having the following features: "generally ten rather prominent obtuselyrounded ribs... small valve (brachial valve) moderately rounded; median rib depressed; and nearly thrice the width of those immediately adjoining it" (King, 1850:129). In addition, the sulcus in King's plate 8, fig. 5 is seen to be shallow and rounded. Obviously, the specimens from England differ at least in external features from South China specimens.

When he described the species Spiriferina mulliplicata Sowerby, Davidson (1858:19) wrote: "The ribs are small, rounded. and rarely exceed ten in number; mesial fold not much produced and either rounded or flattened along its crest." His figures included a specimen that has only 7-8 costae (pl. 1: figs. 45,46 ) and a specimen that has subangular plications (pl. 1: figs. 38, 39). Even though the latter specimen may be comparable to specimens from South China, it does not represent the same species.

The specimens that Waagen (1883) identified as Spiriferina multiplicata are closely similar to Paraspiriferina alpha mentioned above.

Callispirina? rotundella (= Spiriferina multiplicata Huang) is characterized by its high, angular costae, narrow intercostal troughs, and deep V-shape sulcus. It differs from Paraspirifer- ina alpha (Huang) (= Spiriferina multiplicata mut. alpha Huang) in that the latter has low and rounded costae and fold, in sharp contrast to the former. As Grant (1976:231) and Cooper and Grant (1976b:2742, 2743) pointed out, the genus Callispirina differs from the genus Paraspiriferina externally in its sharp plications and fine, regularly spaced growth lines. Although growth lines in our specimens that are preserved as casts are ill-preserved, one specimen partly reveals the fine growth lines that prompted us to place this species in the genus. We are not sure about internal features that will need to be verified in the future.

ETYMOLOGY.-From the Latin, rotunda, meaning round, plus -ella, meaning diminutive.

\section{Suborder ATHYRIDIDINA Boucot, Johnson, and Staton, 1964}

\section{Superfamily ATHYRIDIDOIDEA McCoy, 1844}

Family ATHYRIDIDAE McCoy, 1844

Subfamily SPIRIGERELLINAE Grunt, 1965

Genus Araxathyris Grunt, 1965

Araxathyris beipeiensis sp. nov.

FIGURE 37(1-4)

Medium-size shell, biconvex with shallowly inflated profile; outline subpentagonal transversely; anterior commissure parasulcate and emarginate; growth laminae visible near anterior margin, evenly and regularly spaced.

Pedicle valve gently convex, evenly arched in anterior profile, lateral profile strongly curved near umbonal area; sulcus narrow, beginning near umbonal area, getting wider forward, forming tongue-like turn-up dorsally at anterior edge; no lateral plications; beak short and incurved. Brachial valve somewhat less strongly convex; fold low and flattened at top with median groove originating near umbonal area, getting wider forward; lateral sulci shallow, beginning at midvalve; beak short, incurved.

Pedicle valve interior with dental plates visible from weathered shell (Figure 37(2,3)). Other internal features unknown.

HOLOTYPE.-USNM 456169.

MEASUREMENTS (mm).-

\begin{tabular}{|c|c|c|c|c|c|c|}
\hline \multirow[b]{2}{*}{ USNM } & \multicolumn{2}{|c|}{ Pedicle valve } & \multicolumn{2}{|c|}{ Brachial valve } & \multirow[b]{2}{*}{ Width } & \\
\hline & Length & $\begin{array}{l}\text { Curved } \\
\text { length }\end{array}$ & Length & $\begin{array}{l}\text { Curved } \\
\text { length }\end{array}$ & & \\
\hline 456169 & 13.9 & 19.2 & 13.9 & 14.3 & 17.1 & 9.0 \\
\hline
\end{tabular}

STRATIGRAPHIC OCCURRENCE AND LOCALITY.-Changxing Formation: Beipei section, Zhongqing City, Sichuan Province.

DIAGNOSIS.-Small and transversely subpentagonal Araxathyris with emarginate anterior commissure and flattened fold. 


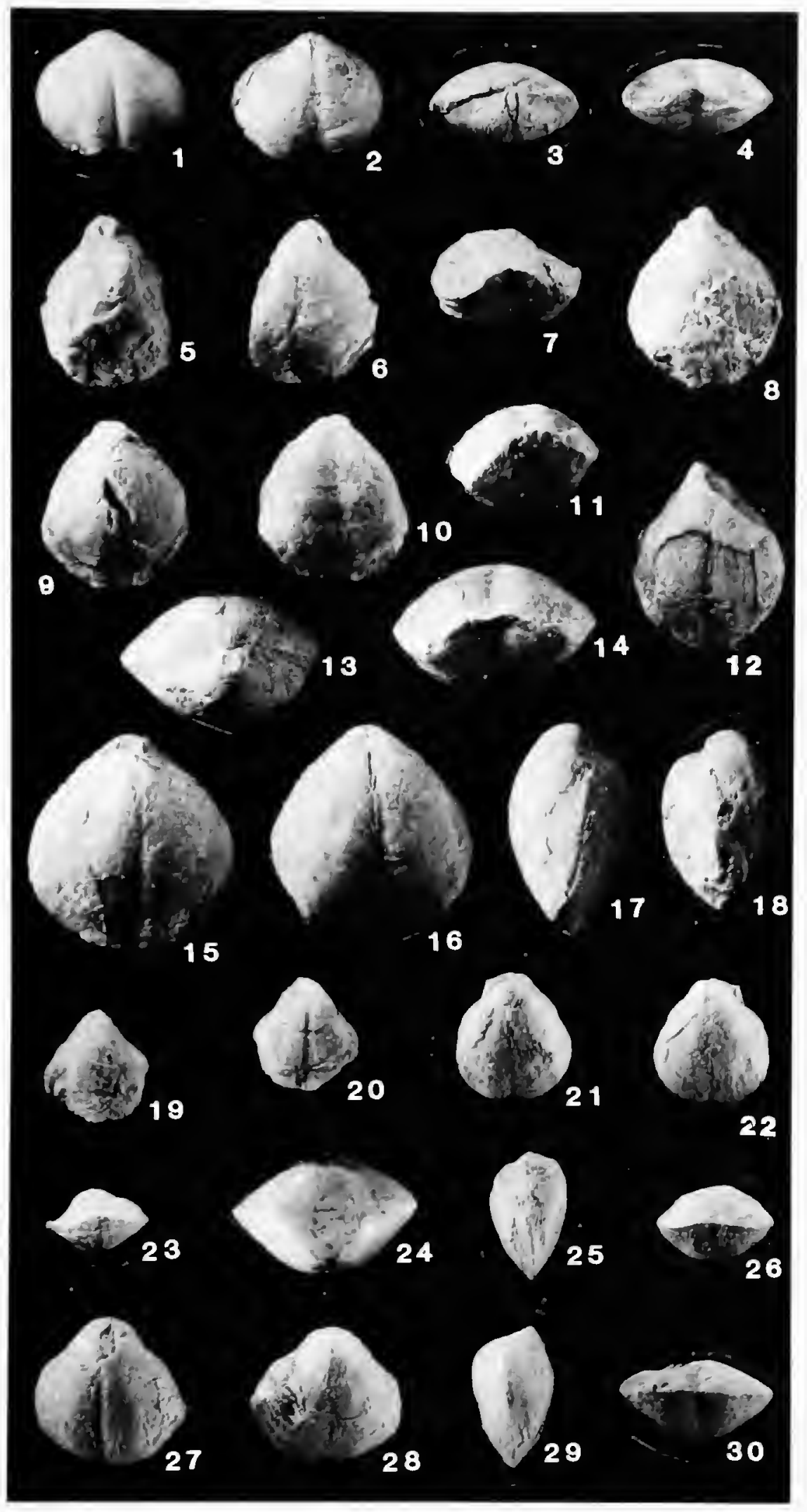

FIGURE 37.-1-4, Araxathyris beipeiensis, new species: dorsal, ventral, posterior, and anterior views $(\times 1)$, from section 8, USNM 456169, holotype. 5-18, Araxathyris subpentangulata. new species: 5-7, dorsal, ventral, and anterior views $(x 1)$, USNM 456165; 8, 12, 18, idem $(x 1)$, USNM 456166; 9-11, idem $(\times 1)$, USNM 456167: 13-17, posterior, anterior, dorsal, ventral, and lateral views $(\times 1)$, USNM 456168, holotype: all from section 32. 19-30. Rectambitus bisulcata (Liao): 19, 20, 23, dorsal, ventral, and anterior views $(\times 1)$, USNM 456170; 21, 22, 25,26, dorsal, ventral, lateral, and anterior views $(\times 1)$, USNM 456171: 27-30, idem ( $\times 1)$, USNM 456172; 24, a cut section showing interior features $(\times 2)$, USNM 456173; all from section 32 . (Reduced to $98 \%$ for publication.)

COMPARISON.-The new species closely resembles $A$. subpentangulata in its anterior commissure and sulcus shape; however, it differs in its transverse outline, valves gently convex, and more obvious lateral sulci. It differs from $A$. zhijinensis Liao (1980a:267, pl. 8: figs. 52, 53) in its transverse subpentagonal outline and parasulcate commissure.

ETYMOLOGY.-From the Latin suffix, -ensis, denoting place.

\section{Araxathyris subpentangulata sp. nov.}

FiguRES 37(5-18), 38

Medium size, moderately biconvex; outline subpentagonal to subelliptical, usually slightly elongate; hinge line short and curved. greatest width near midlength or somewhat anterior to midlength; narrow sulci on both valves, anterior commissure weakly parasulcate, sometimes slightly emarginated; surface smooth with few concentric laminae, irregularly spaced, most frequent near anterior margin.

Pedicle valve moderately and rather evenly convex, greatest

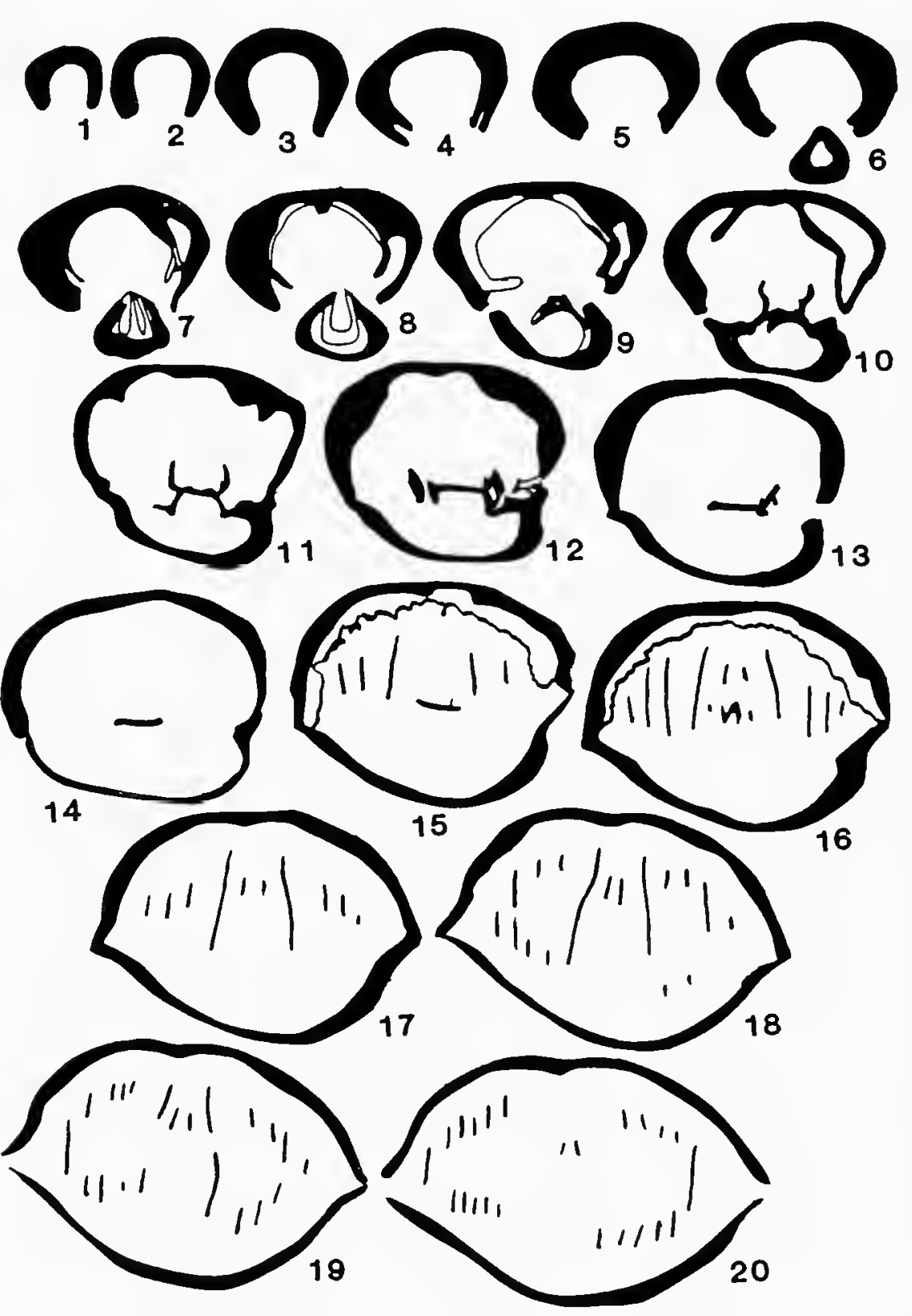

FIGURE 38.-Serial sections of Araxathyris subpentangulata, new species, showing the intemal features. 
convexity somewhat posterior to midlength; beak short, incurved; foramen covered by beak; sulcus from umbonal region narrow, extending over $1 / 2$ length of valve, widening rapidly. Brachial valve somewhat less strongly convex; beak slightly incurved; sulcus narrow from umbonal region to near anterior margin, no fold, only flattened crest at anterior margin.

Pedicle valve interior with small teeth, short thin dental plates fused to wall, only anterior edge free, strongly divergent near floor then curved; muscle area deeply impressed, separated by very low median ridge. Brachial valve interior with thin plate, perforated near posterior margin, at middle part becoming a shallow furrow, short, disappearing when hinge plate flattened anteriorly; hinge socket shallow, inner-socket ridge proportionately high; cardinal process short, comb-like at posterior, bilobed at anterior; crural bases seemingly forming sides of hinge plate; axis of spiralia laterally pointed, including 5-6 volutions per spiralium.

HOLOTYPE.-USNM 456168.

MEASUREMENTS (mm).-

\begin{tabular}{|c|c|c|c|c|c|c|}
\hline \multirow[b]{2}{*}{ USNM } & \multicolumn{2}{|c|}{ Pedicle valve } & \multicolumn{2}{|c|}{ Brachial valve } & \multirow[b]{2}{*}{ Width } & \multirow[b]{2}{*}{$\begin{array}{l}\text { Thick- } \\
\text { ness }\end{array}$} \\
\hline & Length & $\begin{array}{l}\text { Curved } \\
\text { length }\end{array}$ & Length & $\begin{array}{l}\text { Curved } \\
\text { length }\end{array}$ & & \\
\hline 456165 & 26.6 & 35.7 & 24.2 & 28.0 & 25.4 & 15.4 \\
\hline 456166 & 22.9 & 28.9 & 20.0 & 21.7 & 18.5 & 13.1 \\
\hline 456167 & 20.1 & 26.0 & 19.0 & 20.2 & 17.8 & 12.9 \\
\hline 456168 & 13.5 & 16.7 & 11.9 & 12.8 & 12.7 & 7.8 \\
\hline
\end{tabular}

STRATIGRAPHIC OCCURRENCE ANI LOCALITY.-LONgdongchuan Formation: Xikou section, Zhenan County, Shaanxi Province.

DINGNOSIS.-Smooth, subpentagonal outline, with sulci on both valves, anterior commissure usually weakly parasulcate.

COMPARISON.-Araxathyris subpentangulata is characterized by its narrow sulci on both valves and a weakly parasulcate commissure. In these respects it resembles $A$. quadrilobata (Abich, 1878:53, 54, pl. 7: fig. 6, pl. 9: figs. 8, 9; Grunt, 1965:243, 244, pl. 43: figs. 1, 2); but it differs in its smaller maximum size, slightly elongated outline. and sulcus wider at the anterior margin of the pedicle valve. It differs from $A$. zhijinensis Liao (1980a:267. pl. 8: figs. 52, 53) in its subpentagonal outline and parasulcate commissure; the latter species has a triangular shape and an uniplicate anterior commissure.

ETYMOLOGY.-From the Latin prefix, sub, meaning somewhat; latinized from the Greck, penta. meaning five; and from the Latin, angulata, mcaning having angles; hence, somewhat pentagonal.

\section{Rectambitus gen. nov.}

Small to medium size, biconvex, outline subpentagonal to subelliptical slightly elongate or transverse; anterior commissure rectimarginate with emarginate anterior; narrow and shallow sulcus at each valve, brachial sulcus moderately or weakly developed; growth laminae irregularly spaced, most frequent near anterior margin; pedicle beak somewhat incurved, arching over brachial beak.

Pedicle valve interior with strong knob-like teeth; dental plates thin, bow-like, converging together to form spondylium, attached at floor in apical cavity, and supported by low and broad median septum at anterior edge of spondylium; muscle scars narrow, elongate in spondylial floor. Brachial valve interior with undivided hinge plate, thin and flat; hinge socket shallow, inner-socket ridges relatively high; 2 comb-like processes interpreted as cardinal processes, separated widely; crural bases butting between outer and inner hinge plates; athyridid spiralia.

DIAGNOSIS.-Smooth Athyridoidea with rectimarginate commissure and emarginate anterior edge; narrow sulcus in both valves; internally, dental plates convergent, forming spondylium.

COMPARISON.-The new genus is comparable to Araxathyris in having a dorsal sulcus, thin dental plates, and undivided hinge plate. The obvious distinctions are that the new genus has a rectimarginate commissure and a spondylium. It resembles Leptathyris Siehl (1962:212) in its bisulcate and rectimarginate commissure, but that Devonian genus has deeply depressed hinge plates in the dorsal valve and dental plates in the ventral valve, and both plates are fused completely with the shell wall (see A.J. Boucot et al. in Moore, 1965:H633, fig. 538, 4).

TYPE SPECIES.-Araxathyris bisulcata Liao (1980a:268, pl. 9: figs. 14-17).

ETYMOLOGY.-From the Latin, rectus, meaning proper, and ambitus, meaning curvature (of margin). The gender is masculine.

\section{Rectambitus bisulcatus (Liao, 1980), new combination}

FIGURES 38(19-30), 39

Araxathyris bisulcata Liao, 1980a:268, pl. 9: figs. 14-17.

DIAGNOSIS.-Average size for genus; moderately biconvex; greatest width somewhat anterior to midlength, maximum thickness near both umbonal regions; bisulcate, narrow and shallow, pedicle sulcus slightly wider than brachial sulcus; anterior commissure rectimarginate, rounded edge emarginate in middle. Pedicle valve spondylium supported by low and broad median septum extending about $2 \mathrm{~mm}$ at anterior edge of spondylium. Brachial valve with bilobate, comb-like hinge processes, diverging widely.

MEASUREMENTS (mm).-

\begin{tabular}{|c|c|c|c|c|c|c|}
\hline \multirow[b]{2}{*}{ USNM } & \multicolumn{2}{|c|}{ Pedicle valve } & \multicolumn{2}{|c|}{ Brachial valve } & \multirow[b]{2}{*}{ Width } & \multirow[b]{2}{*}{$\begin{array}{c}\text { Thick- } \\
\text { ness }\end{array}$} \\
\hline & Length & $\begin{array}{l}\text { Curved } \\
\text { length }\end{array}$ & Length & $\begin{array}{l}\text { Curved } \\
\text { length }\end{array}$ & & \\
\hline 456170 & 17.9 & 21.2 & 14.1 & 16.0 & 16.6 & 8.8 \\
\hline 456171 & 15.5 & 16.0 & 14.4 & 16.0 & 16.7 & 9.0 \\
\hline 456172 & 15.3 & 18.9 & & 16.1 & 13.5 & 8.8 \\
\hline 456173 & 13.7 & 17.9 & 12.4 & 15.9 & 12.6 & 8.4 \\
\hline
\end{tabular}




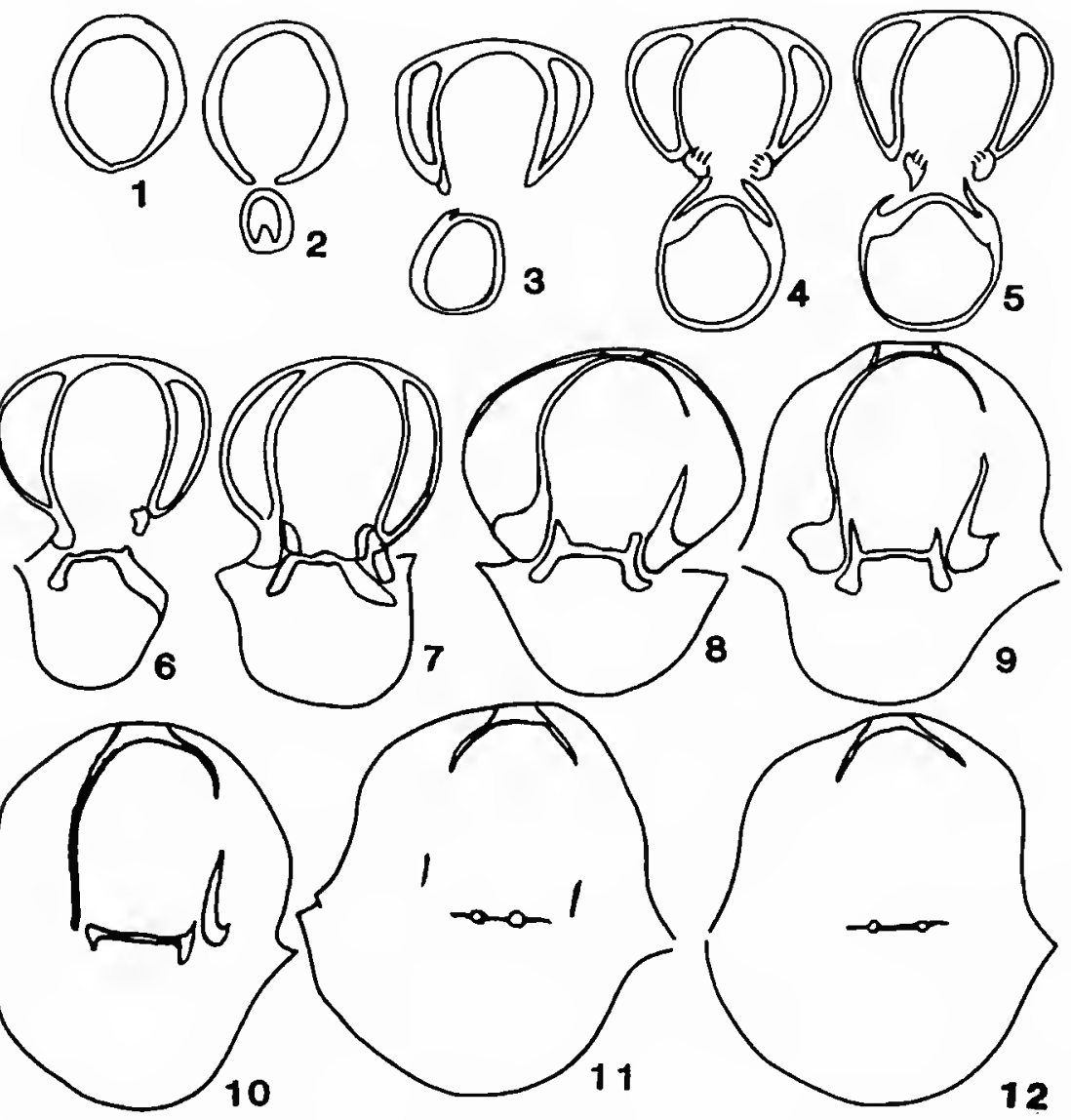

FIGURE 39.-Serial sections of Rectambitus bisulcata (Liao) showing intemal features.

STRATIGRA PHIC OCCURRENCES ANI LOCALITIES._-LOngtan Formation: Qiaozishan section. Anshun County. Guizhou Province. Longdongchuan Formation: Xikou section, Zhenan County, Shaanxi Province.

DISCUSSION.-Liao's (1980a:268) brief description of Araxathyris bisulcata, based on a single specimen from Qiaozishan section, Anshun County, Guizhou Province, emphasized its rectimarginate anterior commissure and narrow sulcus. Examination of our specimens from Xikou section, Zhenan County, Shaanxi Province, shows them to be externally identical to Liao's specimen. Liao did not illustrate the internal features of his specimen, but because he placed it in the genus Araxathyris. we must assume that the specimen has internal features compatable with those of that genus. Rectambitus and Araxathyris differ in that Araxathyris has a spondylium; however, this character easily may be overlooked, and otherwise the two genera share many similar internal features. In addition, the localities for Liao's specimen and our specimens are near the west margin of the South China Sea, and they also share a common age. Based upon all of this, we consider them to be the same species.

\section{Genus Spirigerella Waagen, 1883}

DIAGNOSIS.-Smooth Athyrididae with strongly incurved pedicle beak, fairly sharp brachial beak, uniplicate or parasulcate anterior commissure; pedicle valve interior with bow-like dental plates, with most parts merged into thickened wall; brachial valve interior with flat, undivided hinge plate, posterior part perforated, cardinal process usually well developed or with inner-socket ridges, position of crura usually near sides of hinge plates.

DiscUSSION.-Some species of smooth Athyrididae that occur in the Upper Permian of South China have been assigned incorrectly to the genus Araxathyris. For example, A. shuizhulangensis Chan (in Hou et al., 1979:99, pl. 8: figs. 7, 8, 10, 15, 16) and A. guizhouensis Liao (1980a:268, pl. 9: figs. 1-4) should be attributed to Spirigerella. Every species of Araxathyris has a distinct median groove in the dorsal valve. Examination of a large collection of Araxathyris compiled by Grant from Kuh-e-Ali Bashi, Iran (inventory of USNM), proves that this character is one of the most consistent features of the genus. Araxathyris guizhouensis Liao (= Araxathyris shuizhutangensis Chan) has a trace of a median groove that can be seen only dimly; this character essentially differs from the obvious median groove that is deeply scored and somewhat widened forward. Grant's comparison of Composita with the genus Spirigerella (Grant, 1976:204, 205) pointed out several features that belong especially to Spirigerella: strongly incurved beak with foramen absent or only very small; greatest width farther forward; thickened wall submerging most of dental plates; and crura normally extending from the sides of the hinge plate. In his original description, Waagen (1883:451) said that the genus Spirigerella has an "exceedingly large" cardinal process. The features mentioned by Grant (1976) and Waagen (1883) are visible in the species described below from South China (Figures 42-44). Grant (1976:204) suggested that the species under the name Athyris timorensis (Rothpletz) by Huang (1933) might belong to the genus Spirigerella. This work proves that analysis to be true. Based on its strongly incurved beak, no foramen, no median groove on the fold, thickened wall submerging dental plates in the pedicle valve, and flattened hinge plate in the brachial valve, we place Athyris timorensis in the genus Spirigerella. Araxathyris normally has a roof-like hinge plate (see Grunt, 1965:241).

TYPE SPECIES.-Spirigerella derbyi Waagen (1883:450455, pl. 35: figs. 4-7, 9-13).

\section{Spirigerella discusella sp. nov.}

FIGURES 40, 43(36-47)

Average size for genus; moderately biconvex; outline nearly circular, an oblate spheroid with greatest width at midlength, maximum thickness somewhat posterior to midvalves; anterior commissure rectimarginate or weakly incurved with emarginate or straight edge; growth laminae irregularly spaced.

Pedicle valve evenly and moderately convex in both lateral and anterior profile; beak short and incurved; sulcus narrow and shallow, originating from umbonal region. Brachial valve evenly and slightly inflated in both lateral and anterior profile, 


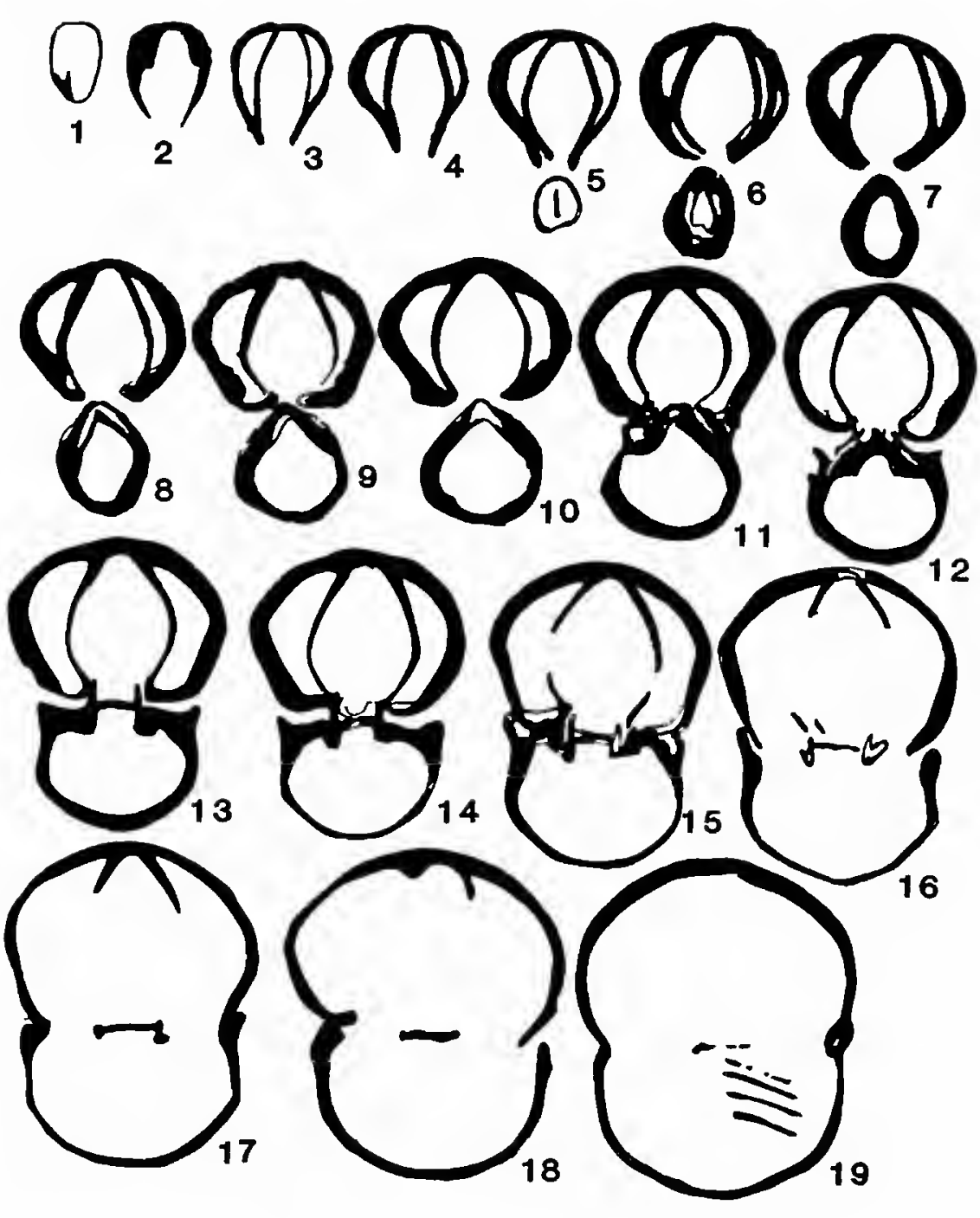

FIGURE 40.-Serial sections of Spirigerella discusella. new species, showing the internal features.

umbonal region roundly arched; no fold; brachial beak strongly incurved, attenuated, and sharply pointed.

Pedicle valve with relatively strong teeth; dental plates thin, converging at apical cavity. Brachial valve with undivided hinge plate; hinge sockets shallow, inner-socket ridges high; crural bases butting between outer and inner hinge plates.

HOLOTYPE.-USNM 456175.

MEASUREMENTS (mm).-

\begin{tabular}{|c|c|c|c|c|c|c|}
\hline \multirow[b]{2}{*}{ USNM } & \multicolumn{2}{|c|}{ Pedicle valve } & \multicolumn{2}{|c|}{ Brachial value } & \multirow[b]{2}{*}{ Width } & \multirow[b]{2}{*}{$\begin{array}{c}\text { Thick. } \\
\text { ness }\end{array}$} \\
\hline & Length & $\begin{array}{c}\text { Curved } \\
\text { length }\end{array}$ & Length & $\begin{array}{l}\text { Curved } \\
\text { length }\end{array}$ & & \\
\hline & 12.4 & 16.6 & 10.8 & 12.6 & 11.9 & 8.0 \\
\hline 456175 & 14.4 & 18.2 & 13.2 & 14.5 & 13.1 & 6.7 \\
\hline
\end{tabular}

STRATIGRAPIIIC OCCURRENCES ANI LOCALITIES.Changxing Formation: Beipei section. Zhongqing City, Sichuan Province; Huangzhishan section, Wuxing County, Zhejiang Province.

DIAGNOSIS.-Oblate spheroid in outline; no fold on brachial valve; anterior commissure rectimarginate or slightly upcurved.

COMPARISON.-Spirigerella discusella, new species, is similar to $S$. shuizhutangensis (Chan in Hou et al., 1979:99, pl. 8: figs. $7,8,10,15,16)$ in its subcircular outline and strongly incurved and attenuated brachial beak; it differs from $S$. shuizhutangensis in its slightly up-curved anterior commissure and lack of fold.

ETYMOLOGY.-From the Latin, discus, meaning a circular plate, plus -ella, diminutive.

\section{Spirigerella guizhouensis (Liao, 1980), new combination}

FiguRES 41(1-51), 42

Athyris timorensis (Rothpletz).-Huang, 1933:69-71, pl. 10: figs. 13-19.Wang et al., 1964:612, pl. 120: figs. 13-16.

Araxathyris guizhouensis Liao, 1980a:268, pl. 9: figs. 1-4.

Medium size, strongly biconvex; outline subcircular, either slightly elongate or slightly transverse, greatest width normally anterior to midlength; anterior commissure parasulcate; growth lines fine, closely spaced, visible only in well-preserved specimens, growth laminae irregularly spaced, most frequent near anterior margin.

Pedicle valve strongly and evenly convex; beak short, pointed or slightly blunt, strongly incurved, usually embracing the brachial beak; sulcus shallow, beginning near midlength and widening rapidly, rounded floor forming relatively wide tongue-like edge, bounded by short, rounded lateral plicae at each side. Brachial valve somewhat less strongly convex, greatest inflation in umbonal region; fold gently arched, parasulcus on each side, shallowly rounded.

Pedicle valve interior with hinge teeth small; dental plates thin, bow-like, free entirely, extending about $1 / 3$ or $1 / 4$ length of valve, converging at floor. Brachial valve interior with small cardinal process, slightly elevated over the posterior edge of hinge plate; hinge plate flat, undivided; dental socket shallow; inner-socket ridges rather high, contacting at sides of hinge plate at approximately right angles; fulcral plates hanging under sockets, low and short; crural bases butting in hinge plate, between inner and outer hinge plates, continuing toward anterior after hinge plate disappears, and connecting with

FIGURE 41 (opposite page).-Spirigerella guizhouensis (Liao): 1-3, 9, 10, dorsal, ventral, anterior, lateral, and posterior views $(\times 1)$, USNM 456177; 4, 5 , 11-13. dorsal, ventral, lateral, posterior, and anterior views $(x 1)$, USNM 4561 79a; 16-20, idem ( $\times 1$ ), USNM 456176; 40-42, 51, dorsal, ventral, lateral, and anterior views $(\times 2)$ and 46 , anterior view $(\times 1)$, USNM $456179 \mathrm{~b} ; 43-45$, dorsal, ventral, and lateral views $(x 1)$ and 47-50, dorsal, ventral, posterior, and anterior views $(\times 2)$, USNM 456180 ; all from section $27.6-8,14,15$, dorsal, ventral, lateral, posterior, and anterior views $(\times 1)$, USNM 456178, from section 4. 23-27, dorsal, ventral, lateral, posterior, and anterior views $(\times 1)$, USNM 456181a: 21, 22, anterior views $(x 1)$, USNM 456181b,c; 29, 30, ventral and lateral views $(x 1) ; 33-35,38,39$, dorsal, ventral, lateral, posterior, and anterior views $(\times 2)$, USNM 456182; all from section 6. 28, 36,37, ventral, dorsal, and lateral views $(\times 2)$ and 31,32 , dorsal and lateral views $(x 1)$, USNM 456218 , from section 8 . 


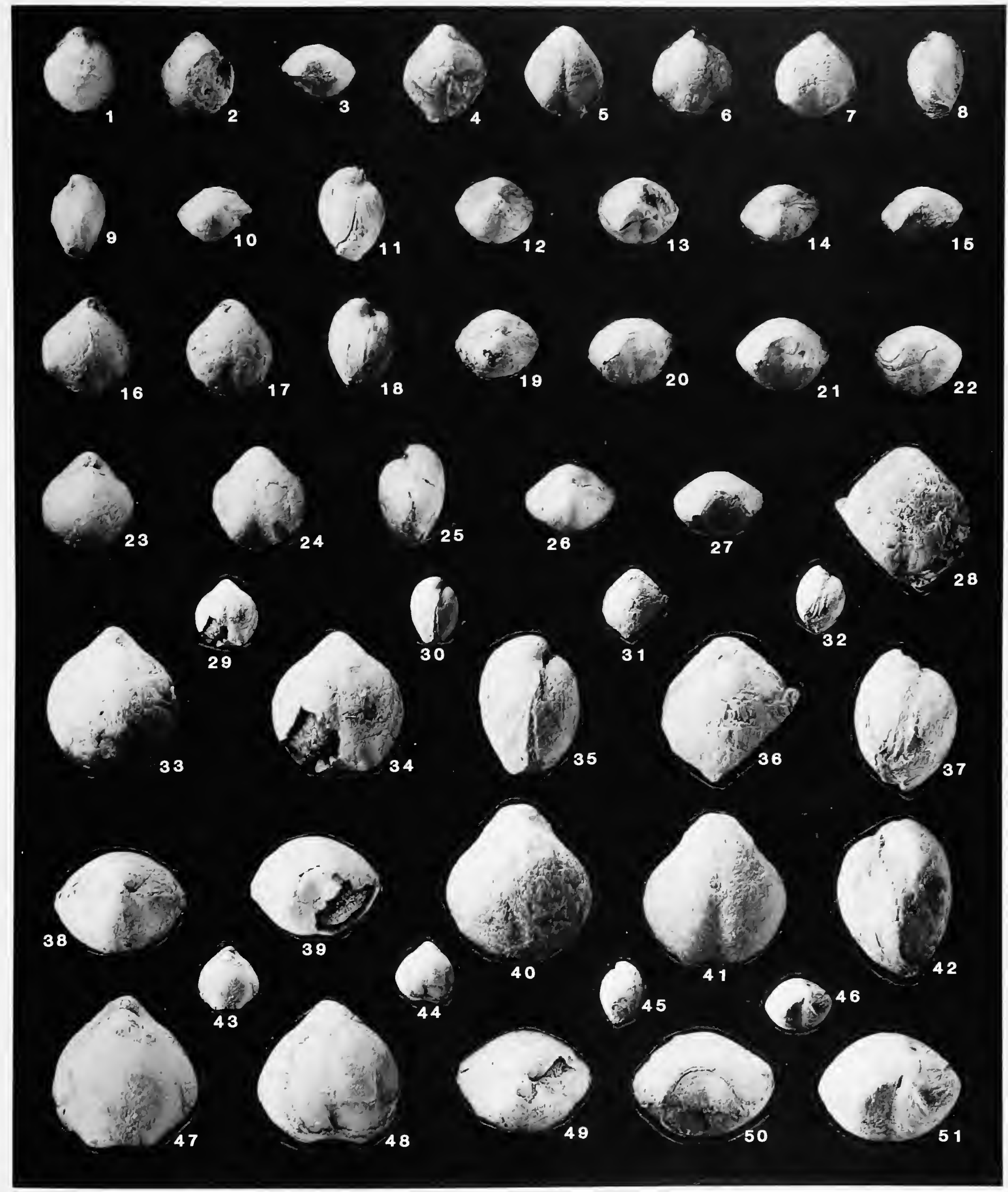




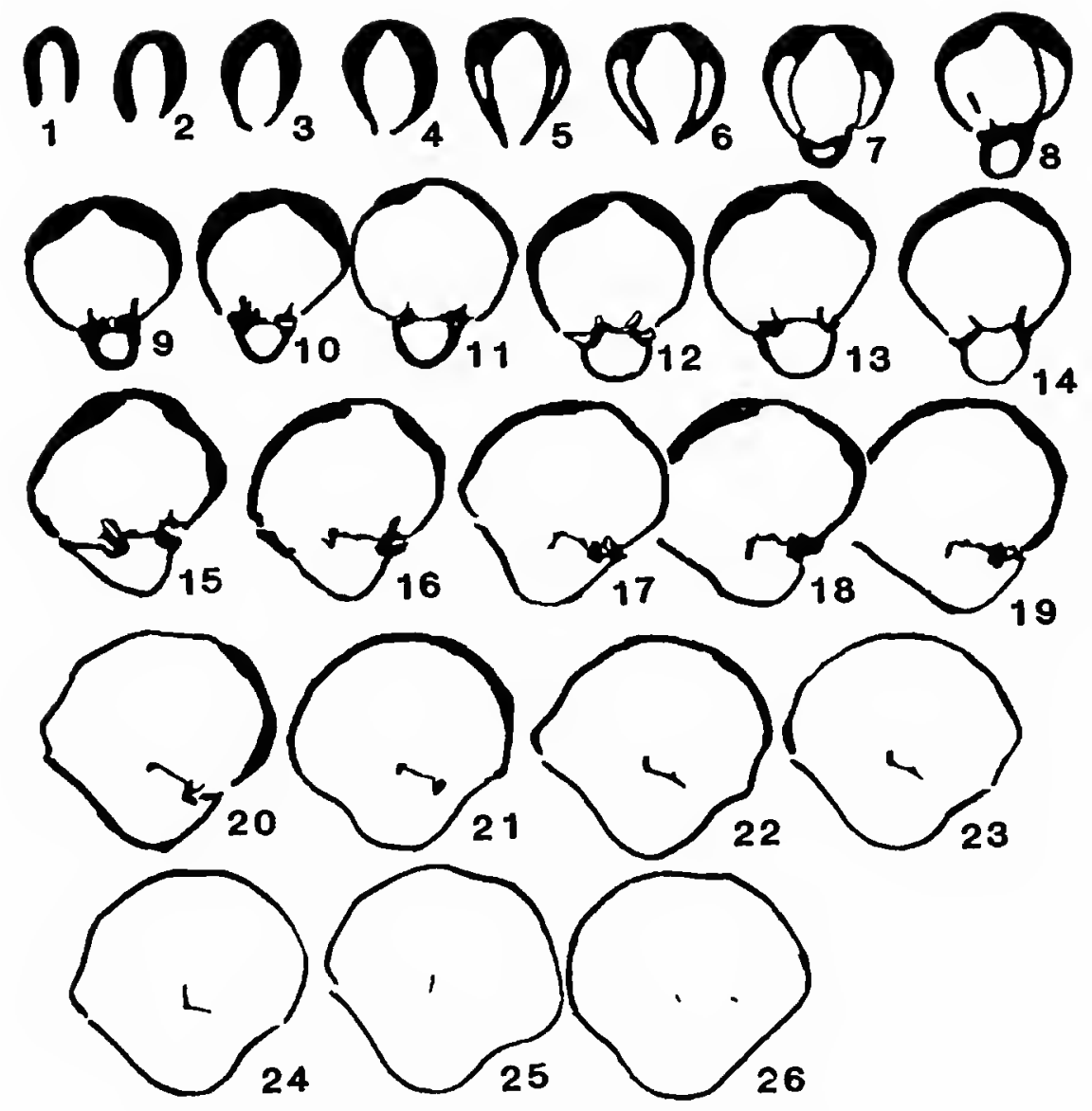

FIGURE 42.-Serial sections of Spirigerella guizhovensis (Liao) showing internal features.

spiralia; muscle scars narrow, separated by median ridge.

MFASUREMENTS (mm).-

\begin{tabular}{|c|c|c|c|c|c|c|c|}
\hline \multirow[b]{2}{*}{ USNM } & \multicolumn{2}{|c|}{ Pedicle valve } & \multicolumn{2}{|c|}{ Brachial valve } & & \multicolumn{2}{|c|}{ Ratio } \\
\hline & Length & $\begin{array}{l}\text { Curved } \\
\text { length }\end{array}$ & Length & $\begin{array}{l}\text { Curved } \\
\text { length }\end{array}$ & Width & $\begin{array}{c}\text { Thick- } \\
\text { ness }\end{array}$ & $\begin{array}{l}\text { lengih to } \\
\text { thickness }\end{array}$ \\
\hline & 16. & 26.2 & 14.8 & 19.5 & 15.8 & 12.4 & 1.36 \\
\hline 45617 & 14.8 & 22.0 & 13.2 & 15.2 & 13.5 & 9.6 & 1.54 \\
\hline 456178 & 14.9 & 19.8 & 13.7 & 16.8 & 14.7 & 10.3 & 1.44 \\
\hline
\end{tabular}

STRATIGRAPHIC OCCURRENCES AND LOCALITIES.Changxing Formation: Huayingshan section, Linshui County; Shangsi section, Guangyuan County; Beipei section, Zhongqing City, Sichuan Province; Huangzhishan section, Wuxing County, Zhejiang Province.

DiAGNOSIS.-Subcircular in outline; parasulcate anterior commissure; beak strongly incurved; internally, dental plates relatively long, converging at floor; hinge plate flat.

COMPARISON.-Spirigerella grandis (Davidson) and $S$. obesa were identified by Huang (1933), based on material from Huayingshan (Hanyuanhsien) section, Sichuan Province, and Zunyi County (Tsunyihsien), Guizhou Province, respectively. Spirigerella guizhouensis differs from them in that $S$. grandis and $S$. obesa are elongate in outline, their sulcus and fold are almost obsolete, and they have strongly swollen umbonal regions (Huang, 1933:75-78, pl. 10: figs. 27-29, pl. 11: figs. $1,2)$.
DISCUSSION.- These specimens are identified here to be the same species as specimens from Guizhou Province that were assigned to Athyris timorensis (Rothpletz) by Huang (1933) and later assigned to Araxathyris guizhouensis by Liao (1980a). It is reasonable to discriminate specimens of South China from Timor's specimens, as Huang (1933:71) implied when he described Athyris timorensis, pointing out that "it is to be noted that our shells do differ from Broili's in some small but definite characters. Firstly, our shells are decidedly smaller in size; secondly, the lateral depressions on the brachial valve are better developed in ours than in the Timor specimens...." As stated in the "Discussion" of the genus Spirigerella, this work assigns Athyris timorensis (Rothpletz) to the genus Spirigerella.

\section{Spirigerella ovaloides sp. nov.}

FIGURES $43(1-15), 44$

Small for genus, strongly biconvex; outline subovate; hinge short and curved, greatest width near midlength; commissure strongly parasulcate; growth lines fine and closely spaced, growth laminae irregularly distributed, most frequent near anterior margin.

Pedicle valve strongly convex; beak pointed and incurved over brachial beak; sulcus shallow, beginning somewhat anterior to midlength, rounded tongue-like at anterior edge, bounded by low, narrow and short plica, with median groove in sulcus, its trace extending to umbonal region in many specimens. Brachial valve somewhat equally strongly convex; beak incurved; fold roundly arched from midlength to anterior margin, parasulci beside fold shallow and narrow, visible only near anterior margin.

Pedicle valve interior with stout teeth; short thin dental plates fused to wall, anterior edge free only for about $1 / 2$ their height; muscle area deeply impressed. Brachial valve interior with thin hinge plate, posterior part somewhat thickened and perforated by pit at posterior edge, becoming median furrow about midlength; hinge sockets shallow, inner-socket ridges forming sides of hinge plate, extending anteriorly, connected with crural bases.

SYNTYPES.-USNM 456183-456185.

MEASUREMENTS (mın).-

\begin{tabular}{|c|c|c|c|c|c|c|}
\hline \multirow[b]{2}{*}{ USNM } & \multicolumn{2}{|c|}{ Pedicle valve } & \multicolumn{2}{|c|}{ Brachial valve } & \multirow[b]{2}{*}{ Width } & \multirow[b]{2}{*}{ Thickness } \\
\hline & Length & $\begin{array}{l}\text { Curved } \\
\text { length }\end{array}$ & Length & $\begin{array}{l}\text { Curved } \\
\text { length }\end{array}$ & & \\
\hline 456183 & 12.6 & 18.0 & 11.2 & 12.1 & 10.1 & 9.5 \\
\hline 456184 & 11.8 & 16.0 & 10.5 & 11.9 & 10.3 & 8.9 \\
\hline $456185 a$ & 11.2 & 16.1 & 10.0 & 11.8 & 9.9 & 8.8 \\
\hline $456185 \mathrm{~b}$ & 11.2 & 16.0 & 10.2 & 12.5 & 10.7 & 8.3 \\
\hline $456185 c$ & 9.7 & 15.5 & 8.4 & 12.0 & 8.3 & 6.7 \\
\hline
\end{tabular}

STRATIGRAPHIC OCCURRENCE AND LOCALITY.-ChangXing Formation: Yutangjiao section, Nantong County, Sichuan Province. 


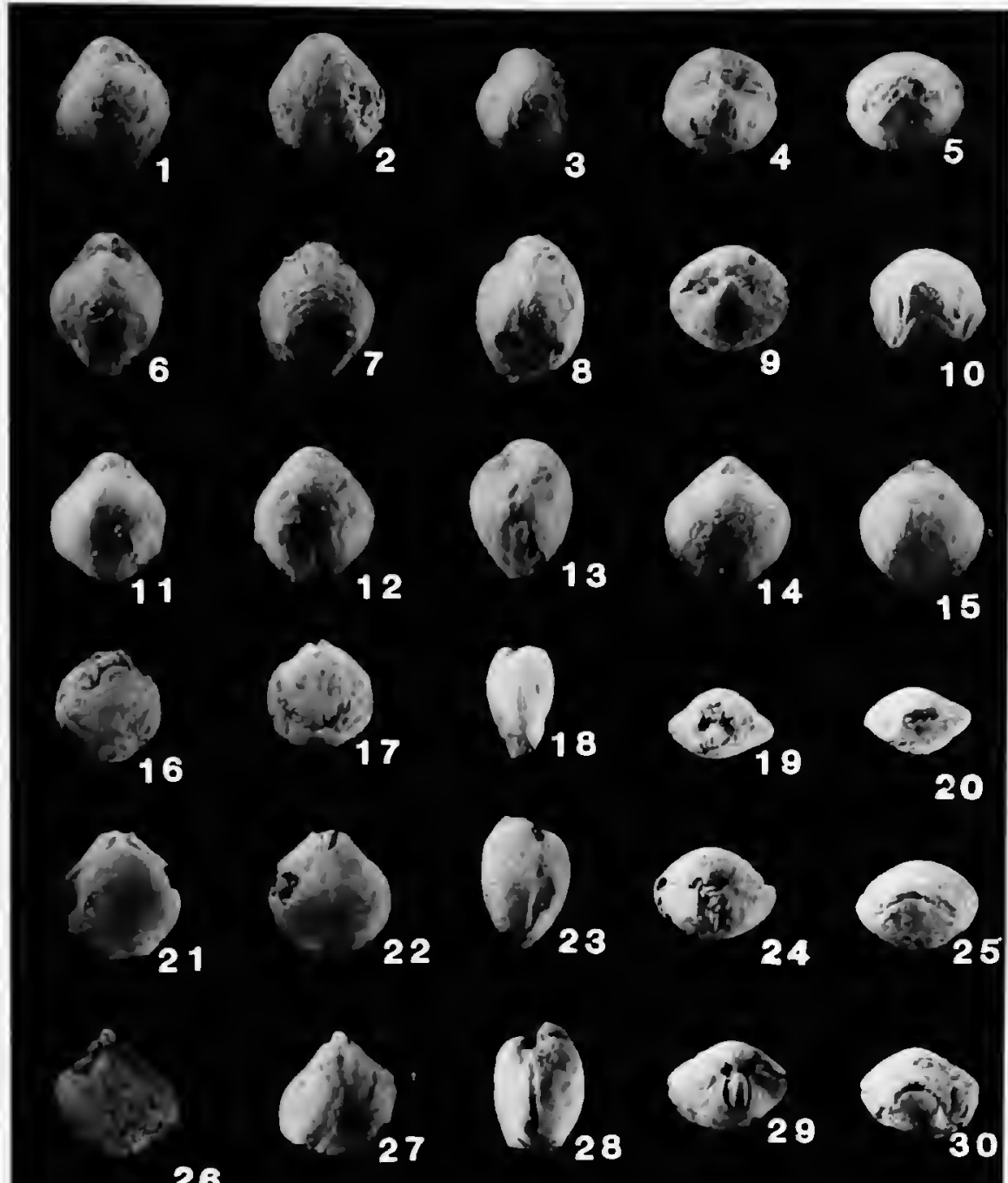

FIGURE 43 (opposite column).-Spirigerella. 1-15, Spirigerella ovaloides. new species: $1-5$, dorsal, ventral, lateral, posterior, and anterior views $(\times 1)$. USNM 456183; 6-10, idem ( $\times 1)$, USNM 456184; $11-15$, idem $(x 1)$, USNM 456185; all from section 9, all syntypes. 16-35, Spirigerella shuizhutangensis (Chan): 16-20. dorsal, ventral, lateral, posterior, and anterior views $(\times 1)$, USNM 456186; 21-25, idem ( $\times 1$ ), USNM 456187; 26-30, idem ( $\times 1)$, USNM 456188; and 31-35, idem $(x 1)$, USNM 456189; all from section 15 . 36-47, Spirigerella discusella, new species: 36-40, dorsal, ventral, lateral, posterior, and anterior views $(\times 1)$, from section 27 , USNM 456174, paratype; 41, 43, 45-47, dorsal, ventral, posterior, anterior, and lateral views $\left(\chi^{2}\right)$ and 42,44 , dorsal and ventral views $(\times 1)$, from section 8. USNM 456175, holotype.
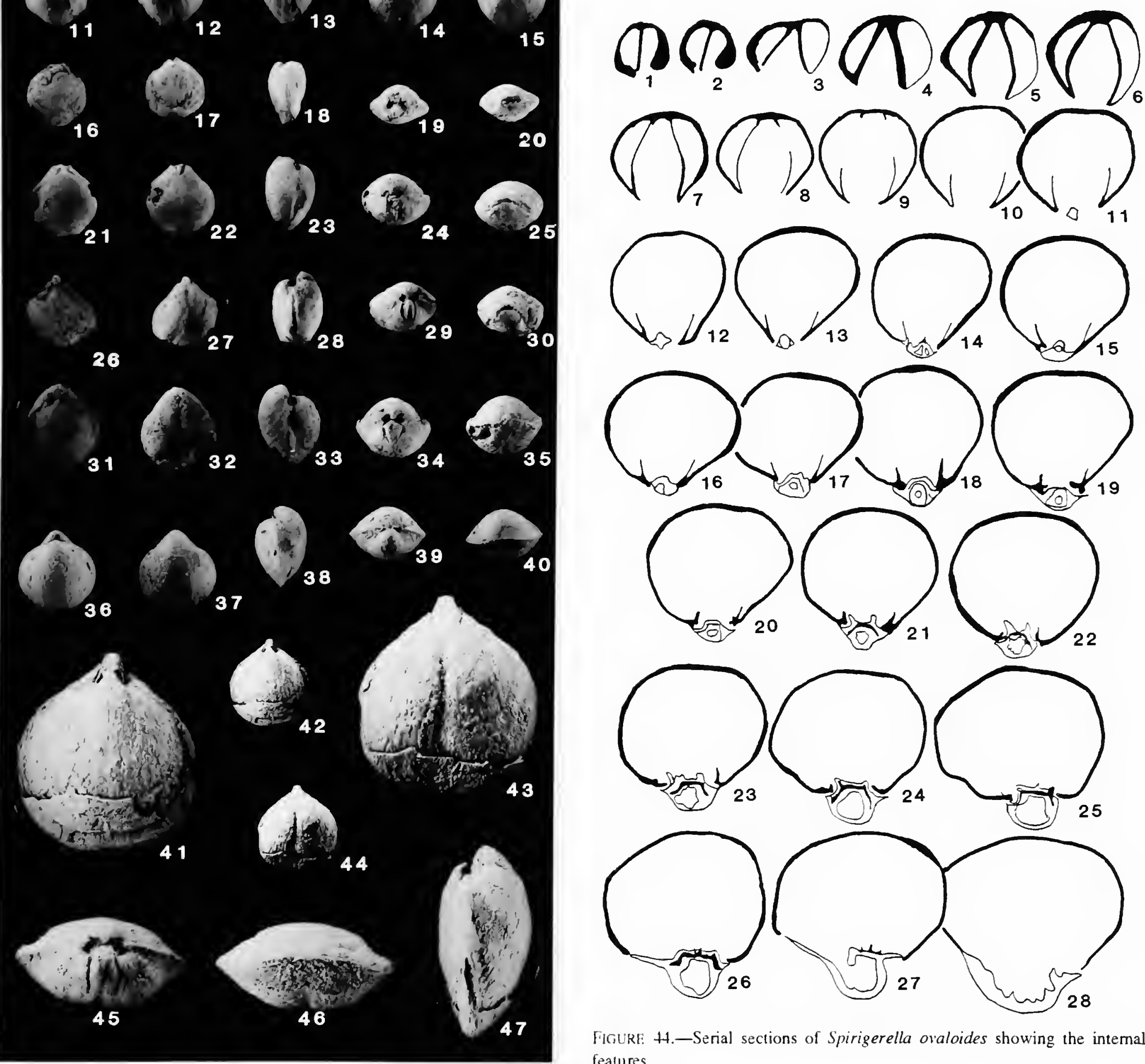

FIGURE 44.-Serial sections of Spirigerella ovaloides showing the internal fealures. 
DIAGNOSIS.-Small, strongly biconvex, strongly parasulcate with narrow and short plica each side of sulcus at anterior edge of pedicle valve, and rounded tongue-like sulcus edge.

COMPARISON.-Spirigerella ovaloides is similar to $S$. derbyi Waagen (1883:453-455, pl. 35: figs. 4-7, 9-13, pl. 37: figs. 11-13; see also Grant, 1976:233, pl. 65: figs. 35-49) in its elongated elliptical, globular, strongly incurved beak, and tongue-like sulcus edge. but the new species has short plicae beside the sulcus, short parasulci beside the fold, and a median groove in the sulcus. The specimen from Qidi Village, Xizang (Tibet), identified by Diener (1897:63, pl. 11: fig. 14) as $S$. derbyi has a proportionately wide sulcus and small shell; therefore, it rather resembles the new species except for the differences mentioned above. The new species is most nearly comparable to $S$. obesa Huang (1933:77, 78, pl. 11: figs. 1, 2) in its size being small, elongate, and obese, but $S$. obesa has neither a fold nor a sulcus. It differs from $S$. pentagonalis Chao (1927:95-97, pl. 1: figs. la-d) in its obvious fold and short parasulci lateral to the fold, and its tongue-like sulcus edge.

ETYMOLOGY.-From the Latin, ovalis, meaning oval, and -oides, meaning similar.

\section{Spirigerella shuizhutangensis (Chan, 1979), new combination}

FiguRES 43(16-35), 45

Araxathyris shuizhutangensis Chan in Hou et al., 1979:99, pl. 8: figs. 7, 8, 10 , $15,16$.

Medium size, moderately to strongly biconvex; outline subtriangular to subcircular, length nearly equal to width or slightly elongate; hinge short and curved, widest anterior to midlength; anterior commissure uniplicate to parasulcate, some specimens only weakly uniplicate; growth laminae irregularly spaced.

Pedicle valve with maximum convexity in posterior part, flattened from midvalve forward; sulcus very shallow to deep, flattened or rounded floor. narrow furrow from umbonal region, widened from midvalve forward; beak small, incurved. Brachial valve with even convexity; fold prominent only near anterior margin; brachial beak incurved, attenuated, and pointed.

Pedicle valve interior with short dental plates, almost converged at floor; teeth stoul. Brachial valve interior with shallow hinge sockets, inner-socket ridges high; hinge plate nat, undivided.

MIASUREMENTS (mm).-

USNM $\frac{\text { Pedicle valve }}{\text { Curved }}$

456186

456187 Length length

\section{$\frac{\text { Brachial valve }}{\text { Curved }}$}

$14.4 \quad 18.0$
Length length Widt

Thick-

456188 12.6

18.0

12.5

11.4

15.8

11.7

$10.5 ? \quad 13.0$
10.7

10.3
14.2

13.1

11.7
13.0

11.8

11.6

10.2

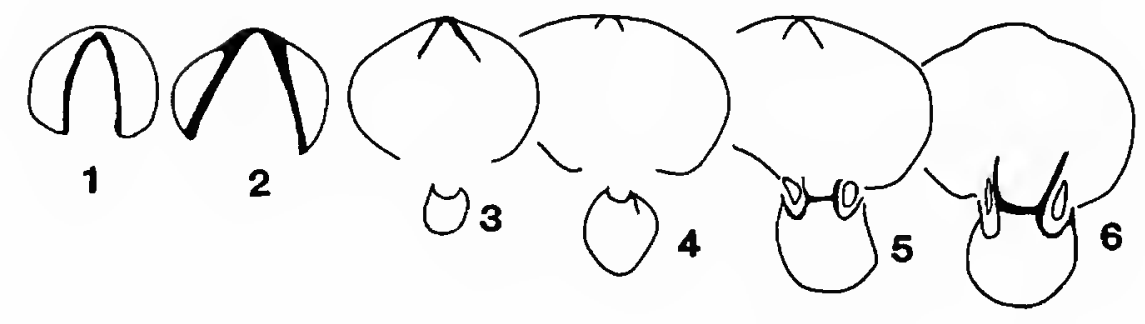

FIGURE 45.-Serial sections of Spirigerella shuizhutangensis (Chan) showing the interior features.

STRATIGRAPHIC OCCURRENCES AND LOCALITIES.-Paoshui Formation: Paoshui section, Laibin County, Guangxi Province. Changxing Formation: Huangzhishan section, Wuxing County, Zhejiang Province.

DIAGNOSIS.-Subcircular-shape Spirigerella with attenuated and pointed brachial beak.

COMPARISON.-Spirigerella shuizhutangensis (Chan) is similar to $S$. guizhouensis in its subcircular outline, shallow sulcus that widens rapidly from midvalve, and convergent dental plates, but the former usually has the anterior part of the pedicle valve more flattened, a wider anterior edge of sulcus, and an attenuated and pointed brachial beak. It differs from $S$. ovaloides. new species, in its medium-size shell, subcircular outline, flattened anterior part of pedicle valve, and attenuated and pointed brachial beak.

\section{Genus Tongzithyris Ching, Liao, and Fang, 1974}

Tongzithyris Ching, Liao, and Fang, 1974:313._Liao, 1980a:268.

Large size, strongly or moderately inflated; outline subpentagonal to subcircular; anterior commissure para-episulcate (not typical episulcate because of no median fold in pedicle sulcus); growth laminae irregularly spaced, most frequent near anterior margin; shell thickened at posterior part.

Pedicle valve strongly convex, lateral slopes moderately steep or gently inclined; beak short, slightly incurved, foramen covered by beak; delthyrium covered by a pair of plates analogous to deltidial plates; sulcus beginning near beak, bounded by 2 gently arched plications, anterior edge tongueshape. Brachial valve somewhat less strongly inflated; beak incurved; fold gently arched with median groove, lateral sulci originating somewhat posterior to midvalve.

Pedicle valve interior with strong teeth; dental plates proportionately thin, bow-like, convergent at floor, forming pseudospondylium by filling with callus. Brachial valve interior with bilobate or comb-like cardinal processes; hinge plate undivided, flat; inner-socket ridges high; muscle scars narrow and elongate, separated by median ridge; spiralia pointed laterally.

COMPARISON.-Tongzithyris resembles certain large species of Araxathyris, such as. A. protea (Abich) from Dzhulfian 
strata at Kuh-e-Ali Bashi. Northeast Iran, and at Dzhulfa, Azerbaijan (Smithsonian Accessions 284193 and 346823), in external features, but the former has more pronounced lateral sulci flanking the fold and a pseudospondylium in the pedicle valve.

Discussion.-Ching et al. (1974) did not point out that this genus has a pseudospondylium in the pedicle valve when they established Tongzithyris as a genus. Liao (1980a:268) redescribed the genus in more detail: "Ventral valve interior with big teeth; dental plates well-developed, bowlike, extending at both sides, converged at floor; median ridge low." After examining specimens of $T$. anshunensis Liao, which has a filled callus between convergent dental plates (Liao, 1980:269, fig. 2), we conclude that a pseudospondylium exists in Tongzithyris. Furthermore, a specimen of Tongzithyris episulcata from Tongzi County, Guizhou Province (Smithsonian Accession 339345), which is an inner core, verifies that a pseudospondylium is clearly visible in the umbonal area (Figure 47(5-8)).

TYPE SPECIES.-Tongzithyris episulcata Ching, Liao, and Fang (1974:313, pl. 165: figs. 10-13).

\section{Tongzithyris sichuanensis Xu, 1987}

FIGURES $46,47(1-4)$

Tongzithyris sichuanensis Xu in Yang et al., 1987:233, 234, pl. 8: figs. 13, 14.

DIAGNOSIS. - Large size, moderately convex; subpentagonal in outline; anterior commissure para-episulcate; pedicle sulcus beginning near beak, roundly shallow with median grove at floor, anterior edge tongue-like, turn-up to dorsal, lateral furrows pronounced near anterior margin; brachial fold starting near umbonal region, dominated at anterior to midvalve with narrow and shallow groove, flanks of fold steeply tilted, lateral

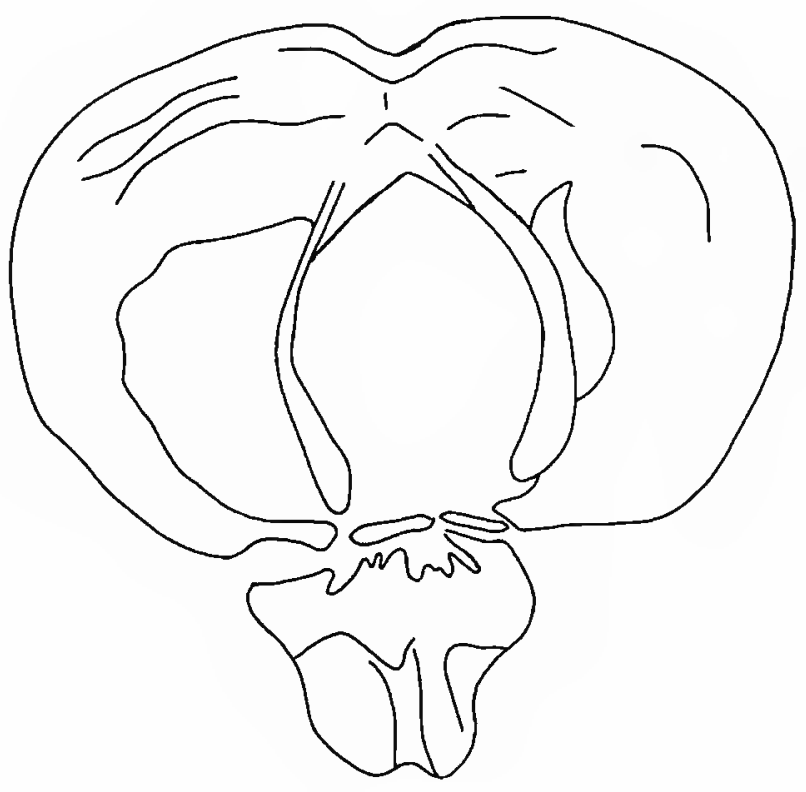

FIGURE 46.-A section near the beak of Tongzithyris sichuanensis Xu showing the pseudospondylium in the pedicle valve and the median ridge in the brachial valve.

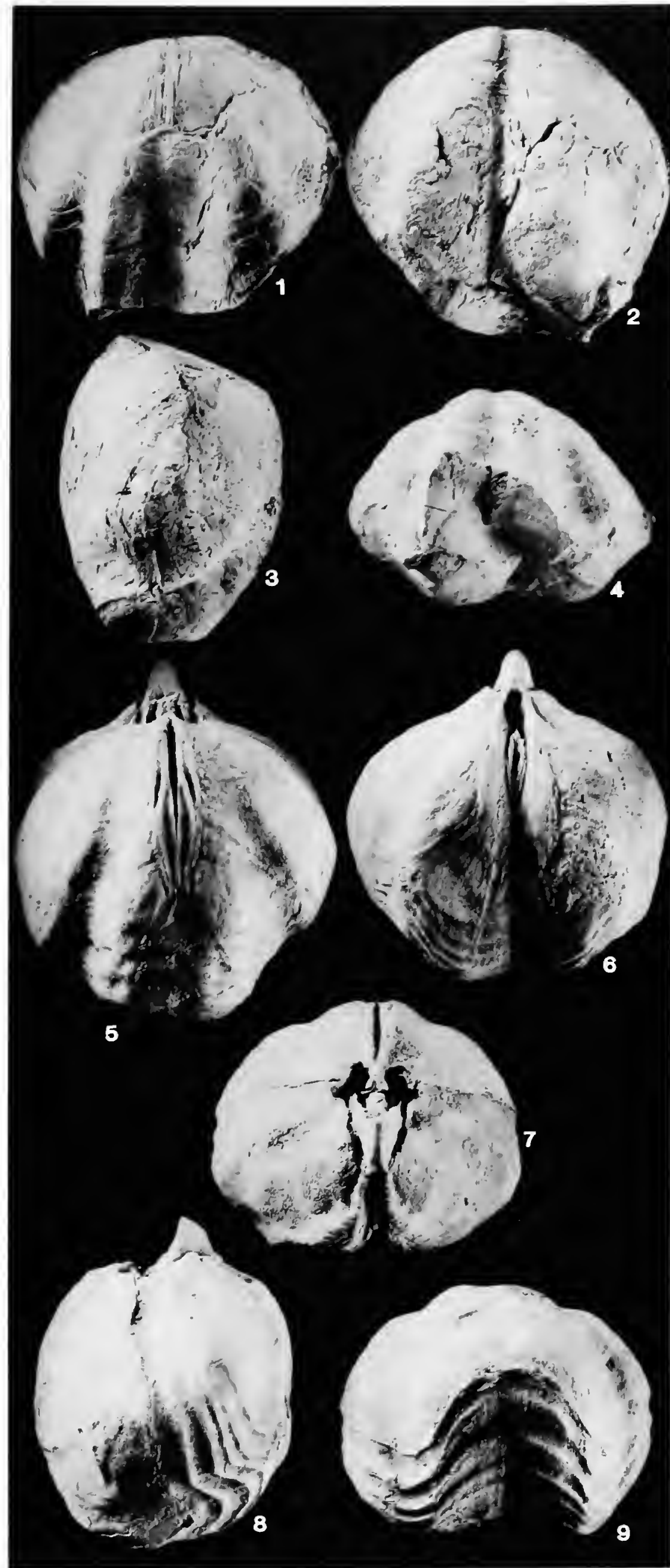

FIGURE 47.-Tongzithyris. 1-4, Tongzithyris sichuanensis Xu: dorsal, ventral, lateral, and anterior views (x1), from section 6, USNM 456190 , holotype. 5-9, Tongzithyris episulcata Ching, Liao, and Fang: dorsal, ventral, posterior, lateral, and anterior views $(\times 1)$, from Tongzi County, Guizhou Province, USNM 481645. (Reduced to $971 / 2 \%$ for publication.) 
plications gently arched, forming asymmetrical lateral sulci between fold and lateral plications.

MEASUREMENTS (mı).-

\begin{tabular}{|c|c|c|c|c|c|c|}
\hline \multirow[b]{2}{*}{ USNM } & \multicolumn{2}{|c|}{ Pedicle valve } & \multicolumn{2}{|c|}{ Brachial valve } & \multirow[b]{2}{*}{ Width } & \multirow[b]{2}{*}{$\begin{array}{c}\text { Thick- } \\
\text { ness }\end{array}$} \\
\hline & Length & $\begin{array}{c}\text { Curved } \\
\text { length }\end{array}$ & Length & $\begin{array}{l}\text { Curved } \\
\text { length }\end{array}$ & & \\
\hline 456190 & 38.0 & 57.5 & 34.0 & 41.8 & 40.0 & 28.5 \\
\hline
\end{tabular}

STRATIGRAPHIC OCCURRENCE AND LOCALITY.-Changxing Formation: Huayingshan section, Linshui County, Sichuan Province.

COMPARISON.- This species is characterized by its roundly shallow sulcus with median groove at floor, gently arched fold with shallow median groove that is flanked by asymmetrical lateral sulci. These features are similar to $T$. episulcata, but the latter has a more inflated and regular-shape shell, median groove that begins at the beak, and a deeply $V$-shape sulcus. It resembles $T$. anshunensis Liao in outline and features of the fold and sulcus, but it differs in that the latter has no lateral plications nor a median groove on either fold.

\section{Superfamily RETICULARIOIDEA Waagen, 1883}

Family ElythidaE Frederiks, 1924

Genus Squaınularia Gemmellaro, 1899

Squamularia formilla sp. nov.

FigURE 48(1-24, 26, 27)

Small. outline subcircular. Icngth and width about equal; widest posterior to midlength of brachial valve; biconvex with pedicle valve more inflated; commissure rectimarginate, neither fold nor sulcus, or, if present, only trace of sulcus on pedicle valve; growth lamellac regularly spaced, more closely spaced on brachial valve than on pedicle valve, numbering about 12-13 and 7-9 per $5 \mathrm{~mm}$. respectively, in juvenile individuals and about 8-10 and 6-8 per $5 \mathrm{~mm}$, respectively, in mature individuals; each edge of lamellac bearing 2 rows of fine pustules, upper row is spine-base scars, in well-preserved specimens fine spines visible, arranged radially with backward pointing spines attaching on each lamella, rarely preserved double-barrelled spine-scars.

Pedicle valve strongly convex with maximum convexity near umbonal area in lateral profile and evenly arched in anterior profile; beak thick, blunt, strongly incurved; interarea small, poorly defined; delthyrium proportionately large and open. Brachial valve slightly and evenly convex; beak short, suberect; notothyrium broad, shallow.

Pedicle valve interior with small teeth, short dental ridges; adminicula and septa absent; delthyrial ridges narrow, furrowed distally, hook-like in cross section view. Brachial valve interior with shallow hinge sockets.

SYNTYPES.-USNM 456191-456195.
MEASUREMENTS (mm).-

$\begin{array}{cccccc}\text { Pedicle } & \text { Brachial } & & & \\ \text { valve } & \text { valve } & \text { Maximum } & \text { Hinge } & \\ \text { USNM } & \text { length } & \text { length } & \text { width } & \text { width } & \text { Thickness } \\ 456191 & 10.1 & 9.0 & 10.6 & 6.5 & 6.1 \\ 456194 & 11.3 & & 11.0 ? & 7.0 ? & \\ 456192 & 18.0 & & 18.5 & & \\ 456195 & 19.3 & 16.7 & 19.5 & 9.8 & 11.3\end{array}$

STRATIGRAPHIC OCCURRENCES AND LOCALITIES.-Longtan Formation: Shatian section, Daye County, Hubei Province. Changxing Formation: Huayingshan section, Linshui County, Sichuan Province; Huangzhishan section, Wuxing County, Zhejiang Province.

DIAGNOSIS.-Small-size Squamularia with two rows of spine scars at edge of each growth lamella, neither fold nor sulcus, and proportionately wide delthyrium.

COMPARISON.-Squamularia formilla, new species, is similar to Squamularia elegantuloides Grabau (1931:198-200, pl. 16: figs. 1a-f, 2) in its wide delthyrium and its rectimarginate commissure with neither fold nor sulcus; however, the Mongolian species is larger, more transverse, and has more prominent concentric lamellae with very fine pustules. Squamularia elegantula (Waagen, 1883:545, 546, pl. 44: fig. 1) has a large shell and a narrow sulcus, so it is readily distinguishable from the new species. Squamularia formilla differs from S. waageni (Loczy) (see Chao, 1929:93-95, pl. 11: figs. 7-11; Grabau, 1931:204-206, pl. 16: figs. 5a-d) in that the latter has a medium-size shell, an elongately ovate outline, and a subelevated pedicle beak. Even though Chao's illustrated specimens present a shallow sulcus and Grabau's specimen has no sulcus, they seem to resemble the new species when characters of the hinge area and the delthyrium are considered. Squamularia formilla resembles S. asiatica Chao (1929:9193, pl. 11: figs. 12-14), which was regarded as the type species when Likharev (1934) established the genus Neophricadothyris, but the spiralia of $S$. asiatica have yet to be found. The new species differs from $S$. asiatica in having a wide delthyrium, small hinge area, and a relatively less convex brachial valve. As Liao $(1980$ a:265, 266) pointed out, $S$. asiatica is a Carboniferous species, but some specimens collected from the Upper Permian were identified as that species. A specimen from the Longtan Formation in Zunyi County, Guizhou Province, identified by Huang (1933:40, 41, pl. 6: figs. 7,8$)$, turns out not

FIgURE 48.-1-24, 26, 27, Squamularia formilla, new species: 1-5, dorsal, ventral, lateral, posterior, and anterior views $(\times 2), 8-10$, dorsal, ventral, and lateral views $(x 1)$, USNM 456191, from section 27; 6, 7, ventral and lateral views $(x 2), 11,12$, ventral and lateral views $(x 1)$, and 23,26 , microomamentation $(\times 10.4, \times 20.8$, respectively), USNM 456194 , from section 6 ; $13-15,19,20$, dorsal, ventral, lateral, posterior, and anterior views $(\times 2)$ and 17 . 18, dorsal and lateral views ( $x 1)$, USNM 456195, from section 17: 16, 22 , dorsal and ventral views $(\times 2)$ and 24,27 , micro-omamentation $(\times 10.4, \times 20.8$, respectively), USNM 456193; 21 , ventral view $(x 2)$, USNM 456192; all from section 6, all syntypes. 25, 28, Neophricadothyris sp.: micro-omamentation (×10.4), USNM 481647, 481646, respectively. 


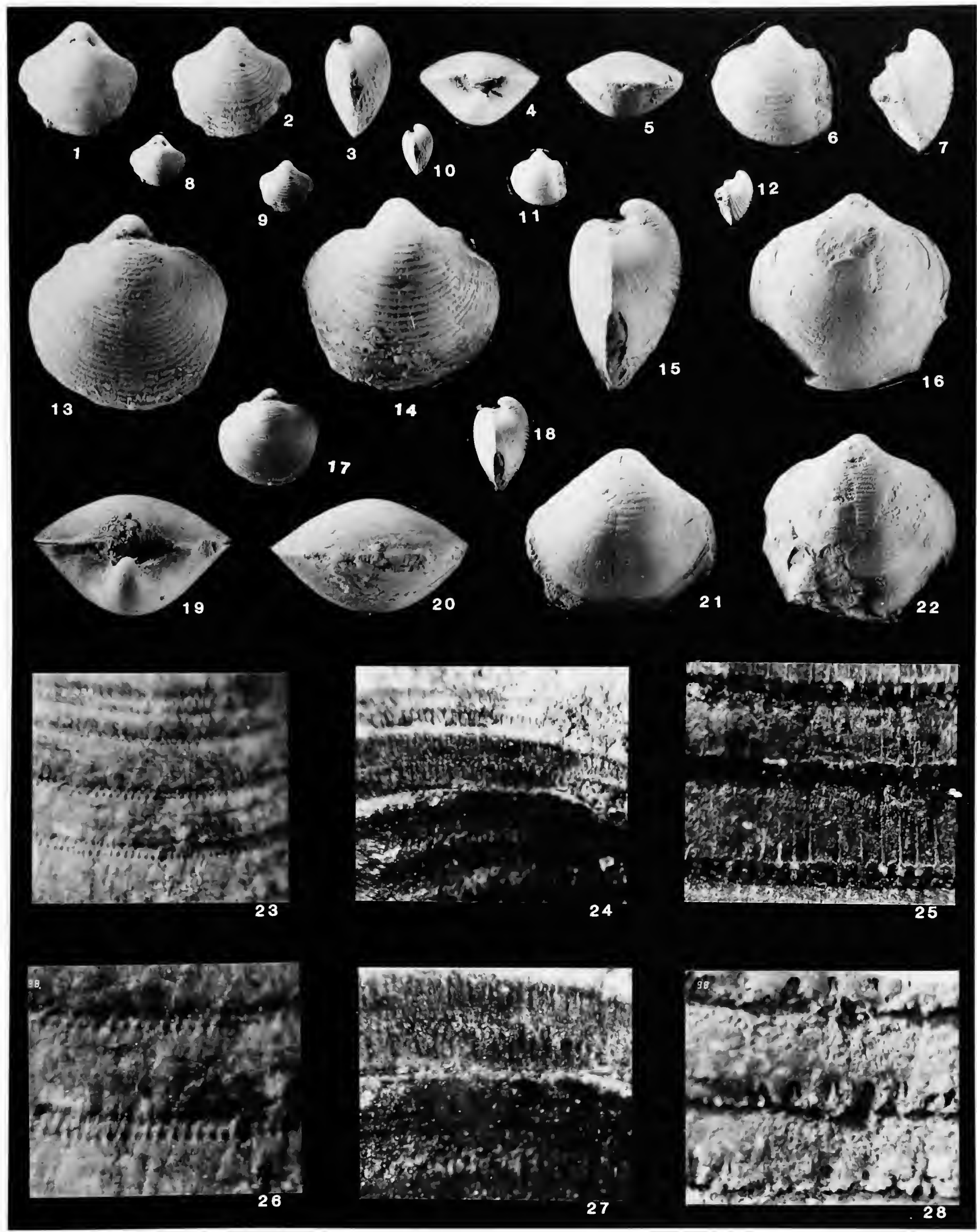



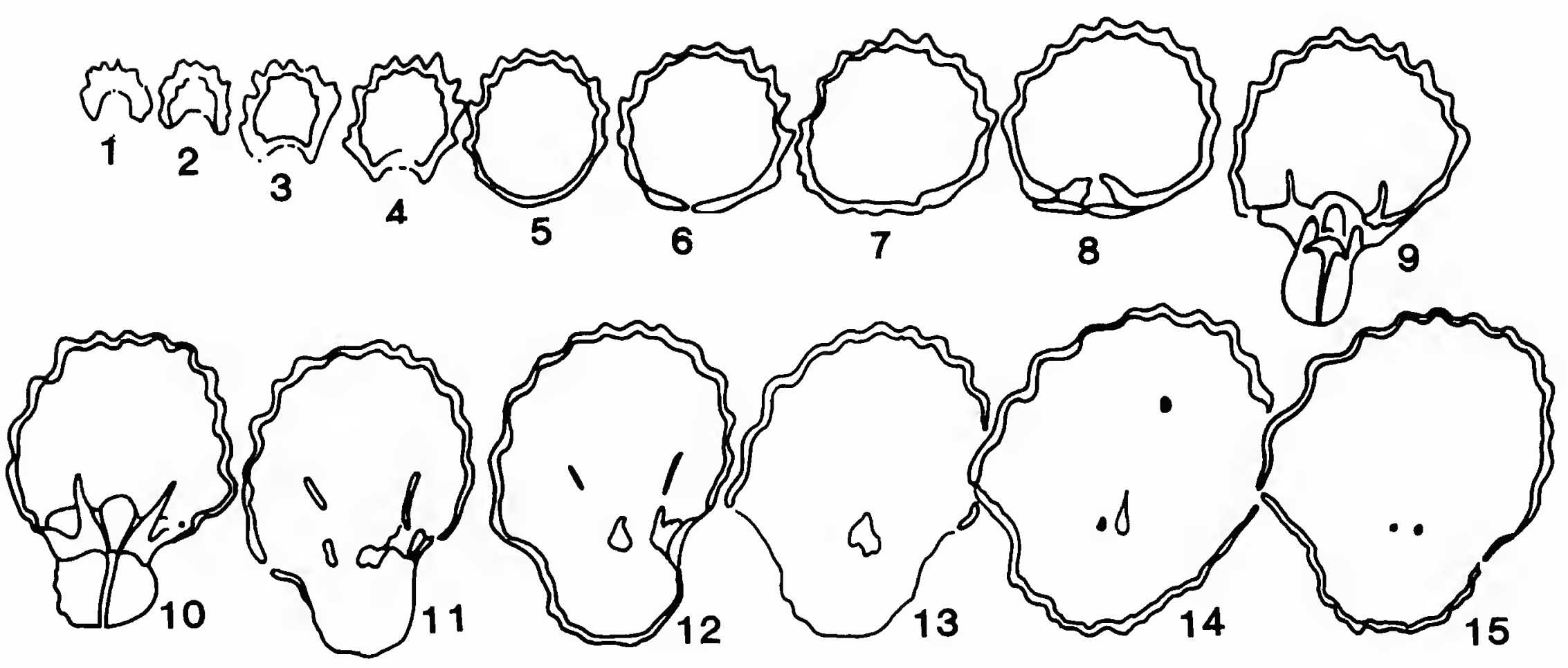

FIGURE 49.-Serial sections of Hustedia orbicostata, new species, showing the intemal features.

to be that species. The new species differs from Huang's specimen in that it has no pseudodeltidium.

ETYMOLOGY.-From the Latin, forma, pretty, and -illa, diminutive.

Suborder RETZIIDina Boucot, Johnson, and Staton, 1964

Superfamily RETzIOIDEA Waagen, 1883

Family ReTZIIDAE Waagen, 1883

Genus Hustedia Hall and Clarke, 1893

Hustedia orbicostata sp. nov.

FiguRes 49, 50(1-23)

Medium size for genus, moderately biconvex; outline elongately subovate; commissure strongly serrate; neither fold nor sulcus present; costae strong, rounded, numbering 10-12 on pedicle valve, 9-11 on brachial valve.

Pedicle valve moderately convex, greatest convexity near umbo, slowly curved to anterior in lateral profile; anterior profile flattened or slightly arched with inclined sides; beak short, suberect; foramen round, mesothyridid; delthyrium relatively large, covered by deltidial plates. Brachial valve slightly more strongly convex with maximum convexity at posterior; beak blunt, slightly incurved over hinge.

Pedicle valve interior with stout teeth, tooth ridges very short; pedicle collar not well preserved. Brachial valve interior with median septum high but short, only in umbonal area; hinge plate greatly thickened with proportionately big hole at posterior part and ligulate process projecting anteriorly; hinge sockets narrow with high inner-socket ridges; crura rod-like, short; spiralia unknown.

SYNTYPES.-USNM 456196-456198.

MEASUREMENTS (mm).-

\begin{tabular}{|c|c|c|c|c|c|c|c|}
\hline \multirow[b]{2}{*}{ USNM } & \multicolumn{2}{|c|}{ Pedicle valve } & \multicolumn{2}{|c|}{ Brachial valve } & \multirow[b]{2}{*}{ Width } & \multirow[b]{2}{*}{$\begin{array}{c}\text { Thick- } \\
\text { ness }\end{array}$} & \multirow{2}{*}{$\begin{array}{c}\text { Pedicl } \\
\text { valve } \\
\text { costae }\end{array}$} \\
\hline & Length & $\begin{array}{l}\text { Curved } \\
\text { length }\end{array}$ & Length & $\begin{array}{l}\text { Curved } \\
\text { length }\end{array}$ & & & \\
\hline & 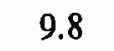 & 7 & 70 & 8.1 & 7.5 & 6.1 & 0 \\
\hline 56 & 9.9 & 12.9 & 8.4 & 8.2 & 8.0 & 6.1 & \\
\hline
\end{tabular}

STRATIGRAPHIC OCCURRENCES AND LOCALITIES.Changxing Formation: Yutangiiao section, Nantong County; Beipei section, Zhogqing City, Sichuan Province. Lower Yinkeng Formation: Huangzhishan section, Wuxing County, Zhejiang Province.

DIAGNOSIS.-Medium-size Hustedia with rounded costae, no fold and sulcus, but with high median septum in brachial valve.

COMPARISON.-Two species of the genus, Hustedia indica (Waagen) and $H$. remota (Eichwald), have been reported in Upper Permian rocks of South China. Hustedia orbicostata, new species, most nearly resembles the specimen from Guiyang County, Guizhou Province that was identified as $H$. indica by Huang (1933:78, 79, pl. 11: figs. 3, 3a-c; see also Wang et al., 1964:639, 640, pl. 126: fig. 21). It differs from Huang's $H$. indica in that the new species has more than ten costae and lacks a sulcus and fold. Eumetria indica Waagen (1884:492-494, pl. 35: figs. 1, 2) has a globular outline, width nearly equal to length, and plications fewer than ten, thus, it is distinguished easily from the new species. According to Huang's description, $H$. remota has plications numbering 12 on the pedicle valve and 14 on the brachial valve and has a remarkable character in that "the interplical spaces are 


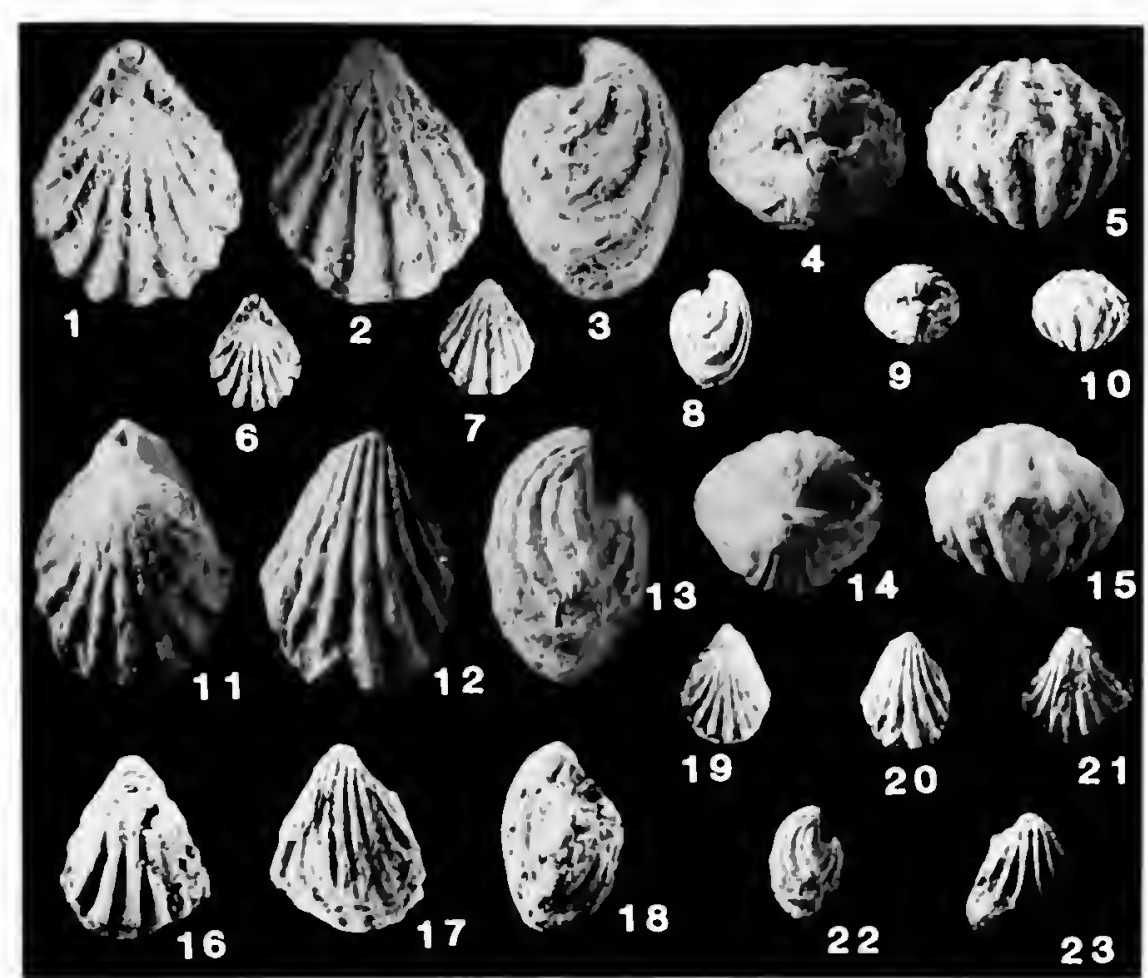

FIGURE 50.-Hustedia orbicostata, new species: 1-5. dorsal, ventral, lateral, posterior, and anterior views $(\times 2)$ and $6-10$, idem $(\times 1)$, USNM 456197, from section 9; 11-15, dorsal, ventral, lateral, posterior, and anterior views $(\times 2)$ and 19. 20, 22, dorsal, ventral, and lateral views ( $x 1$ ). USNM 456196, both from section 27: 16-18, dorsal, ventral, and lateral views. $(\times 2)$, USNM 456198 , from section 8: 21, ventral view ( $x 1)$, USNM 456199: 23, idem $(x 1)$, USNM 456200, both from section 27; all syntypes. (Reduced to $971 / 2 \%$ for publication.)

distinctly flat-bottomed and appear wider than the plicae" (1933:81). Obviously, Huang's specimens collected from Dading County (Tatinghsien), Guizhou Province, differ from the new species. Grabau (1931:125-128, pl. 7: fig. 8a-e; 1934:103, 104. pl. 7: fig. 3) emphasized the "sub-rotund" outline of $H$. remota, and the figure shown by Huang (1933, pl. 11: fig. 5) is virtually circular in outlinc. Another specimen of H. remota. described by Grabau (1934:103, 104, pl. 7: fig. 3), is "nearly as wide as long." Thus, the new species is readily distinguishable from $H$. remota.

Hustedia orbicostata, new species, is similar to $H$. spicata Cooper and Grant (1976b:2799. 2800, pl. 741: figs. 12-40) in both nonelevated median costa on the brachial valve and high median scptum, but it differs in that the new species has rounded costae and neither fold nor sulcus. It somewhat resembles H. cepoidea Cooper and Grant (1976b:2767-2769, pl. 732: Figs. 56-85) in its outline and costae numbers, but the latter has angular costae and a low median septum. Hustedia decollatensis Cooper and Grant (1976b:2778, 2779, pl. 735: figs. 54-68) is readily distinguishable from the new species in that the former has a low median ridge rather than a septum in the brachial valve even though they both are similar in their numbers of rounded costae and in having neither fold nor sulcus.

ETYMOLOGY.-From the Latin, orbis, meaning circle, and costata, meaning ribbed (rounded costac).
Order TeRebratulida Waagen, 1883

\section{Superfamily CRYPTONELloidea Thomson, 1926}

Family NOTOTHYRIDIDAE Likharev, 1960

Genus Rostranteris Gemmellaro, 1899

Rostranteris ptychiventria sp. nov.

FIGURES $51,52(1-16)$

Small, usual size for genus; unequally biconvex; elongateovate to subtriangular in outline, widest anterior to midvalve or near anterior margin; sides broadly rounded to slightly angular; anterior commissure antiplicate; surface of brachial valve with posterior $1 / 2$ smooth but anterior $1 / 2$ plicated, plicae on pedicle valve beginning from umbonal area, interspaces somewhat narrower than plicae; growth laminae well developed near anterior margin.

Pedicle valve strongly convex in lateral profile with umbonal area fairly strongly curved with maximum convexity near midvalve, anterior profile strongly domed, crest serrate and sides sloping steeply or moderately; 2 strongest median costae forming fold. each side having 1 or 2 moderate costae. Brachial valve gently inflated, with steep anterior slope in lateral profile, anterior profile flattened or slightly depressed at median region, forming steep slope at each side; sulcus observable near anterior margin, bounded by 2 strong plicae, median plica in sulcus sometimes weak, sometimes strong, but always slightly lower than lateral plicae; each side having 1-2 plicae.

Interior of pedicle valve without dental plates but with strong dental ridges, teeth stout. Brachial valve interior with small bilobate cardinal process; hinge sockets slit-like with strong inner-socket ridges; hinge plate undivided, flat, perforated at posterior edge; crural bases rod-like, butting in both sides of hinge plate and touching inner-socket ridges; loop centronelliform, long, extending about $3.5 \mathrm{~mm}$, with high median plate that extends beyond conjunction of main hands.

HOLOTYPE.-USNM 456201.

MEASUREMENTS (mm).-

\begin{tabular}{|c|c|c|c|c|c|c|}
\hline \multirow[b]{2}{*}{ USNM } & \multicolumn{2}{|c|}{ Pedicle valve } & \multicolumn{2}{|c|}{ Brachial valve } & \multirow[b]{2}{*}{ Width } & \multirow[b]{2}{*}{$\begin{array}{c}\text { Thick. } \\
\text { ness }\end{array}$} \\
\hline & Length & $\begin{array}{l}\text { Curved } \\
\text { length }\end{array}$ & Length & $\begin{array}{l}\text { Curved } \\
\text { length }\end{array}$ & & \\
\hline 456201 & $10.1 ?$ & 17.1 & 8.2 & 10.2 & 12.5 & 8.5 \\
\hline 456203 & 10.2 & $14.9 ?$ & 7.5 & 9.5 & 8.1 & 8.0 \\
\hline 456202 & $11.2 ?$ & 14.2 & 9.8 & 11.0 & 9.7 & 7.2 \\
\hline
\end{tabular}

STRATIGRAPHIC OCCURRENCE AND LOCALITY.-Longdongchuan Formation: Xikou section, Zhenan County, Shaanxi Province.

DiAGNOSIS.-Small, antiplicate commissure; anterior $1 / 2$ plicated on brachial valve, plicae beginning from umbonal area on pedicle valve.

COMPARISON.-This new species is mainly characterized by its long plicae on the pedicle valve, which distinguishes it from 


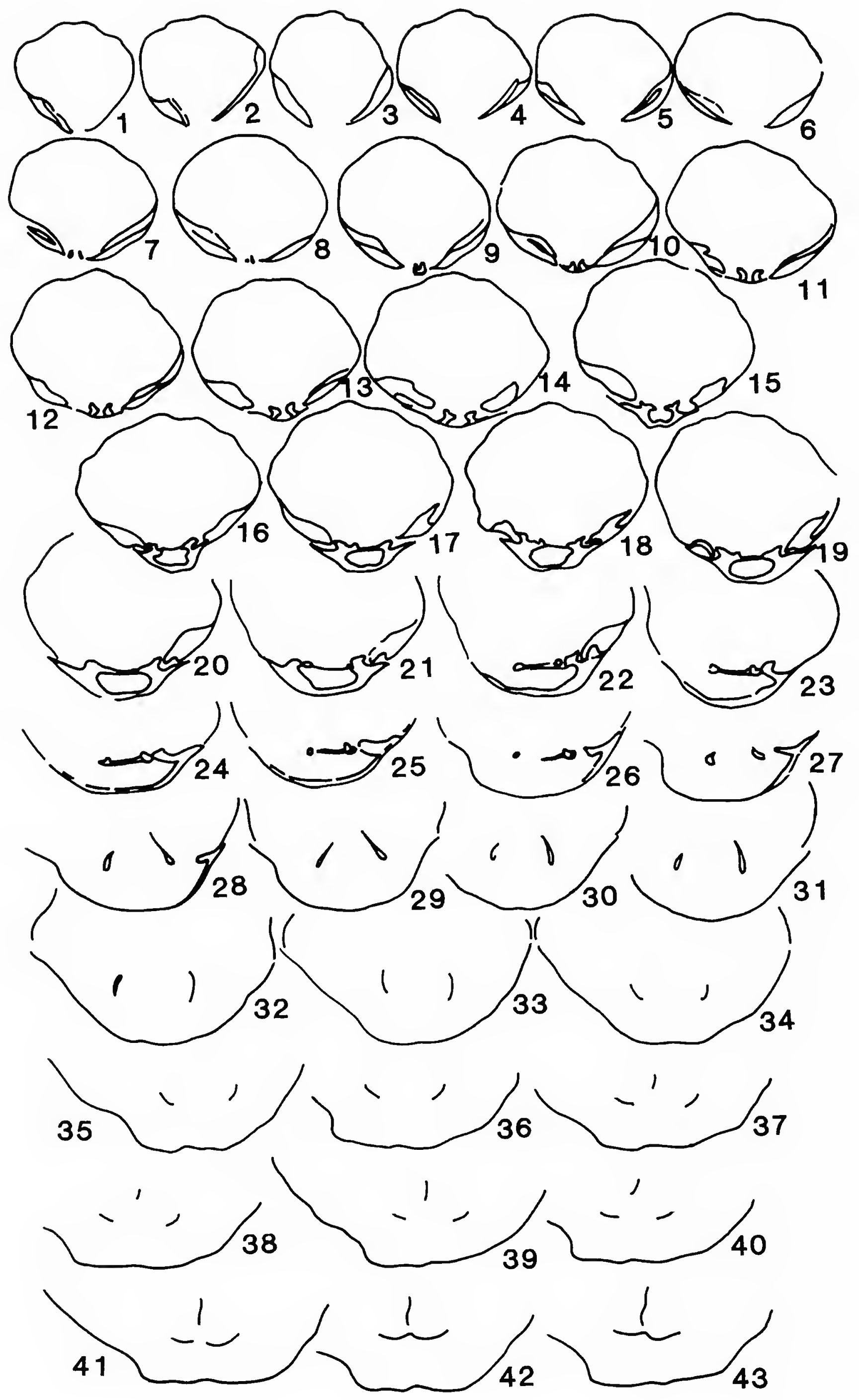

FIGURE 51.-Serial sections of Rostranteris ptychiventria, new species, showing the intemal features. 


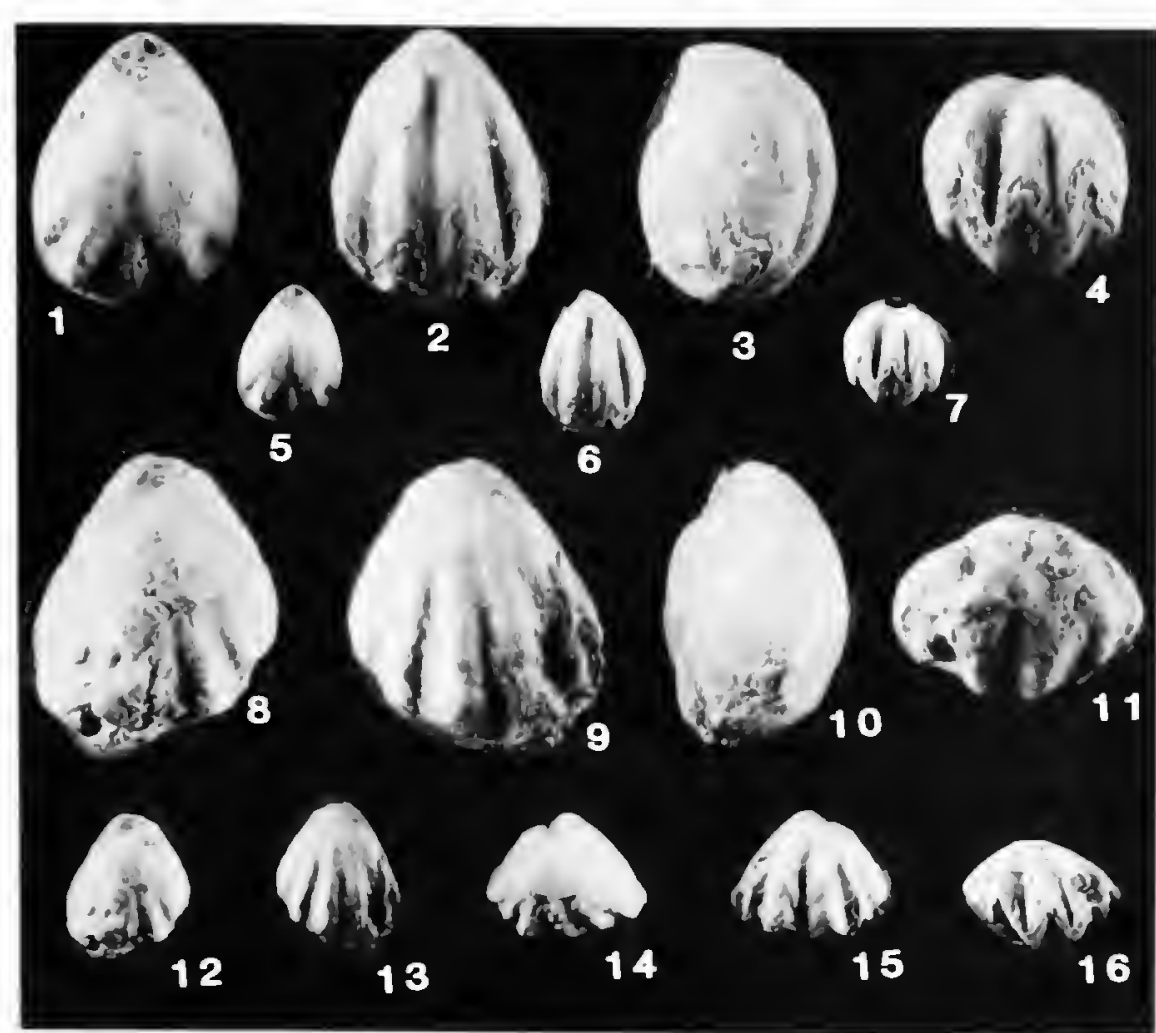

Figl'RF. 52.-Rostranteris ptychilentria. new species: 1-4, dorsal, ventral, lateral. and anterior views ( $\times 2)$ : 5-7, dorsal, ventral, and anterior views $(\times 1)$, LSTM \$56201, holotype: 8-11, dorsal, ventral, lateral, and anterior views (x2). LSIM1 456203. paratype: 12, 13, dorsal and ventral views $(\times 1)$, LSTM 156203, paralype: 14-16, dorsal, ventral, and anterior views $(x 1)$, LS 1 M 456202. paratype: all from section 32.

most oher species of the genus Rostranteris. Rostranteris adrianensis Gemmellaro (1899:105. 106, pl. 25: figs. 35-39; see al so Stehli, 1962:100, pl. 20: group A) has five weak plicae, three on the brachial valve and two on the pedicle valve, which set out near the frontal margin. This arrangement forms a striking contrast to the new species, which has strong plicae, more than 4 on each valve. Rostranteris pulchrum Gemmellaro (1899:106, pl. 25: figs. 58-62) is similar to the new species in its size and outline, but it is readily distinguishable in that the former has rather less thickness and has weak and shor plicae. Rostranteris gibbosum Gemmellaro (1899:1 10, pl. 25: figs. 40. $41)$ has a relatively big, swollen shell and a conspicuous pedicle sulcus (USNM Accession 180508), although it is comparable to the new species in having long plicae on the pedicle valve. Rostranteris prychiventria, new species, closely resembles $R$. inflatum Geminellaro (1899:109, pl. 25: figs. 42-45, pl. 30: fig. 41: Stchli. 1962:100, 101, pl. 20: group B) in its appearance. including shell size. outline. and profile. but it differs in that the latter has an obvious pedicle sulcus and relatively short plications originating near midvalve. It is extcrnally comparable to Mongolina subdieneri Grabau (1931:103-105, pl. 8: figs. 5a-1). which has short plicae and whose interior features are not known.

DISCUSSION.-Several species of the genus have the pedicle valve sulcus, for example, $R$. simuatım Gemmellaro (1899:111, pl. 25: figs. 52-57: USNM Accessions 180508, 183389. and 22.52.39) has a typical sulcus in the pedicle valve and a rather broad interspace between the two main plications. In the new species, however, the interspace between the two main plications on the pedicle valve is narrower than the plications, so it is unreasonable to call it a "sulcus" in this case.

ETYMOLOGY.-From the Greek, prychos, meaning fold, and from the Latin, venter, meaning front (as in ventral).

\section{Genus Notothyris Waagen, 1882}

Notothyris bifoldes sp. nov.

FiguRES 53, 54(1-4)

Small, moderately biconvex, elongate ovate in outline, greatest width near midlength; sides smoothly rounded, anterior margin subtruncated; anterior commissure rectimarginate with sharp angular indentation; surface smooth except for anterior $1 / 3$ where marked by $8-9$ plications; 5 somewhat strong plications forming low fold with slightly depressed crest, brachial valve of some specimens having 3 median plications somewhat lower than 2 bound-lateral plications; 2 somewhat strong plications bounding low fold on pedicle valve, those having 2 slightly weakened plications between them; 1 or 2 lateral plications at each side; growth lines weak, occasionally raised.

Pedicle valve strongly and evenly convex in lateral profile, with rounded bow-like curvature; anterior profile evenly rounded with steep sides; beak erect and slightly incurved; foramen circular, mesothyridid; delthyrium appearing to be covered by deltidial plates. Brachial valve somewhat less strongly convex; beak pointed, incurved.

Pedicle valve interior with strong pedicle collar in delthyrial cavity; no dental plates, teeth stout. Brachial valve interior with shallow hinge sockets, fulcral plates strong but short, innersocket ridges low; hinge plates fused together, crural bases forming at sides of hinge plates; posterior foramen seemingly expressed as narrow lube: muscle scars narrow oval-shape at umbonal region.

HOLOTYPE.-USNM 456205.

MEASUREMENTS (mm).-

\begin{tabular}{|c|c|c|c|c|c|c|}
\hline \multirow[b]{2}{*}{ USNM } & \multicolumn{2}{|c|}{ Pedicle valve } & \multicolumn{2}{|c|}{ Brachial valve } & \multirow[b]{2}{*}{ Width } & \multirow[b]{2}{*}{$\begin{array}{c}\text { Thick- } \\
\text { ness }\end{array}$} \\
\hline & Length & $\begin{array}{l}\text { Curved } \\
\text { length }\end{array}$ & Length & $\begin{array}{l}\text { Curved } \\
\text { length }\end{array}$ & & \\
\hline 45620 & 10.2 & 13.6 & 8.0 & 8.6 & 7.8 & 6.8 \\
\hline 456205 & 10.4 & 13.3 & 9.0 & 9.5 & 8.4 & 7.1 \\
\hline
\end{tabular}

STRATIGRAPHIC OCCURRENCES AND LOCALITIES.Changxing Formation: Huangzhishan section, Wuxing County, Zhejiang Province. Paoshui Formation: Paoshui section, Laibing County, Guangxi Province.

DIAGNOSIS.-Small, elongately ovate; anterior commissure rectimarginate with sharply indented margin; 7-8 plications; weak folds on both valves.

COMPARISON.-Multiple plications at anterior $1 / 3$ and 2 weak folds on both valves distinguish this from other species of the genus. Notorhyris triplax Grant (1976:253, 254, pl. 46: figs. 


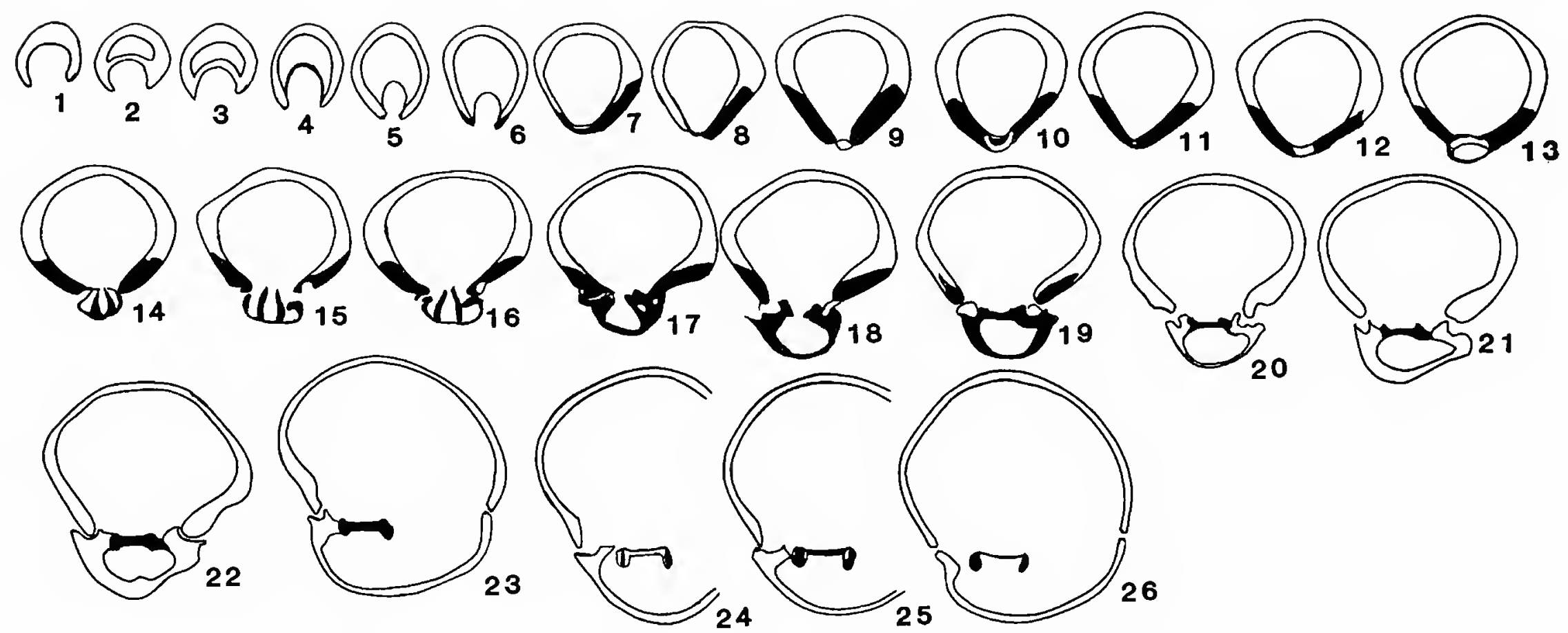

FIGURE 53.-Serial sections of Notothyris bifoldes, new species, showing the internal features.

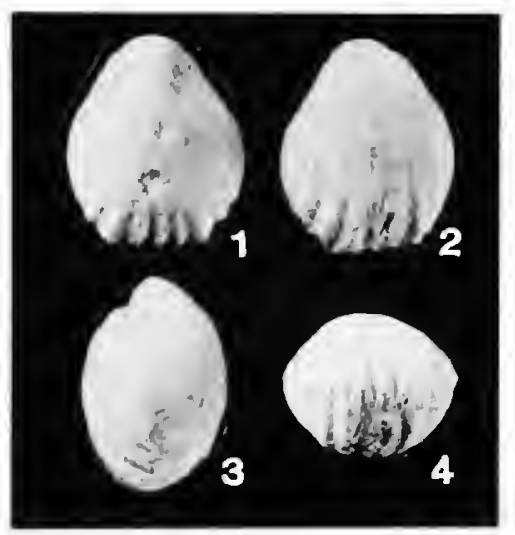

FIGURE 54. - Notothyris bifoldes, new species: 1-4, dorsal, ventral, lateral, and anterior views ( $\times 1.5$ ), from section 15, USNM 456205, holotype.

1-8) is similar to the new species in outline, but it differs in having 3 plications on the dorsal valve and 4 on the ventral valve. As Grant pointed out, $N$. praelecta Reed (not Waterhouse and Piyasin, 1970) has more than 5 plicae on the dorsal valve (Grant, 1976:253), and Reed (1944:167) described it as "bearing 6 subangular longitudinal plications." Thus, the number of plicae of $N$. praelecta seems to resemble the new species; however, $N$. bifoldes is smaller than $N$. praelecta, and $N$. praelecta has 2 median plicae that are much stronger than others on the pedicle valve. Notothyris bifoldes, new species, strongly resembles $N$. revocata Reed in respect to number and nature of median plications, which initially caused us to identify it as the same species, but considering the uncertain nature of the Salt Range species' internal structures and obvious external differences, we describe this new species as differing from $N$. revocala in its small size, elongately ovate outline, no sulcus on the brachial valve, and fewer lateral plications.

DISCUSSION.-The interior structures of the new species basically coincide with genera Notothyris Waagen and Rostranteris Gemmellaro, but we have not ascertained what type of loop it contains. The cardinalia in several genera of the family Notothyrididae are almost the same, but the loops are different. The external dimension seems to reflect the shape of the loop among families within the Upper Permian. For example, Notothyris has numerous plications and an anterior commissure that is rectimarginate to faintly sulcate (Stehli in Treatise, 1965:H758; Grant, 1976:253); Rostranteris has an intraplicate anterior commissure (Stehli in Treatise, 1965:H759); and Timorina has 2,3 , or more median plications on the pedicle valve that are raised into a slight fold (Stehli in Treatise, 1965:H760). Accordingly, we hereby place the new species in the genus Notothyris, although it may be that $N$. praelecta is attributable to Timorina Stehli, 1961. Furthermore, the interior features of $N$. bifoldes, new species, is compatible with the internal features of four species of Notothyris, which Likharev (1936:268-271, figs. 4-7) revealed in his serial sections.

ETYMOLOGY.-From the Latin, bi, meaning two, and foldes, is a play on the word "fold." 


\section{Literature Cited}

Abich, $\mathrm{H}$.

1878. Geologiscle Forschungen in den kaukasischen Ländern, I: Eine Bergkalkfauna aus der Ara.resenge bei Djoulfa in Armenien. 128 pages, 11 plates. Wien.

Ahluwalia. A.D.

1989. Upper Palaeozoic of Lahul-Spiti. In The Peripatetic Fossils, Pant 3. Nature, 341:13-15.

Assereto, R., A. Bosellini, N. Fantini Sestini, and W.C. Sweet

1973. The Permian-Triassic Boundary in the Southern Alps (Italy). In A. Logan and L.V. Hills, editors, The Permian and Triassic Systems and Their Mutual Boundary. Memoirs. Canadian Society of Petroleuin Geologists, 2:176-199. Calgary.

Bando, $Y$.

1964. On Some Lower and Middle Triassic Ammonoids from Japan. Transactions and Proceedings of the Palaeontological Society of Japan, new series, 56:332-345.

Bassi, U.K.

1989. The Kinnaur Region. In The Peripatetic Fossils, Part 3. Nature, $341: 15-16$

Bhatia, S.B.

1989. Early Devonian Ostracodes. In The Peripatetic Fossils, Part 3. Nature, 341:15.

Broglio Loriga, C., C. Neri, and R. Posenato

1980. The "Lingula Zone" of Scythian (Lower Triassic) Stratigraphy and Palaeoecology. Annali dell'Università di Ferrara (new series), Scienze Geologiche e Paleontologiche, 6(6):91-130, table 5.

Chao, Y.T.

1927. Productidae of China, Part I: Producti. Geological Survey of China, Palaeontologia Sinica. series B, 5(2): 244 pages, 16 plates.

1928. Productidae of China, II: Chonetinae, Productinae and Richthofeniinac. Geological Survey of China, Palaeontologia Sinica. series $B, 5(3)$ : 103 pages, 6 plates.

1929. Carboniferous and Permian Spiriferids of China. Geological Survey of China, Palaeontologia Sinica, series B, 11(1): 133 pages, 11 plates.

Ching, Y.K. [Jin, Y.G., or Jing, Y.G.], X.L. Liang, and S.S. Wen

1977. Additional Material of Animal Fossils from Permian Deposits on the Northern Slope of Mount Qomolumgma. Scientia Geological Sinica. 3:236-249.

Cooper, G.A., and R.E. Grant

1969. New Permian Brachiopods from West Texas. Smithsonian Contributions to Paleobiology, 1: 20 pages, 5 plates.

1974. Permian Brachiopods of West Texas, 1I. Smitlsonian Contributions to Paleobiology, 14:233-793, plates 24-191.

1975. Permian Brachiopods of West Texas, 111. Smitlssonian Contributions to Paleobiology, 19:794-1920, plates 192-502.

1976a. Permian Brachiopods of West Texas, 1V. Smithsonian Contributions to Paleobiology, 21:1923-2607, plates 503-662.

1976b. Permian Brachiopods of West Texas, V. Smillsonian Contributions 10 Paleobiology, 24:2609-3159, plates 663-780.

Cooper, G.A., and H.M. Muir-Wood

1951. Brachiopod Homonyms. Journal of the Waslington Academy of Sciences, 41(6): 195, 196.

Dagys, A.S.

1965. Triasovye Brakhiopodi Sibiri. 186 pages, 26 plates. Moscow: Akademiia Nauk SSSR, Sibirskoe Otdelenie, Institut Geologii i Geofiziki.
Davidson, T.

1858-1863. A Monograph of the British Fossil Brachiopoda, II: Permian and Carboniferous Species, Part 5: The Carboniferous Brachiopoda. Paleontographical Society Monographs, 1858-1863:1-280, plates $1-55$.

Diener, C.

1897. Himalayan Fossils; The Permocarboniferous Fauna of Chitichun, No. 1. Memoirs of the Geological Survey of India, Palaeontologia Indica, series 15, 1(3):1-105, 13 plates.

1903. Permian Fossils of the Central Himalayas. Memoirs of the Geological Survey of India, Palaeontologia Indica, series 15, 1(5): 204 pages, 10 plates.

1915. The Anthracolithic Fauna of Kashmir, Kanaur and Spiti. Memoirs of the Geological Survey of India, Palaeontologia Indica, new series, 5(2): 135 pages, 11 plates.

Dunbar, C.O.

1955. Permian Brachiopod Fauna from Central East Greenland. Meddelelser om Gronland, 110(3): 169 pages, 32 plates.

Feng, R.L., and Z.L. Jiang

1978. Brachiopoda. Paleontologic Atlas of Southwestern China, Guizhou Province, 2:231-304, plates 85-108. Beijing.

Fischer de Waldhein, G.

1825. Notice sur la Choristite, genre de Coquilles bivalves fossiles du gouvernement de Moscou. Program dInvitation á la Societe Imperiale des Naturalistes de Moscou, 11 pages, 1 plate. Moscow.

Frederiks, Georg

1924 ("1919"). Etudes paleontologiques, 2: Sur les Spiriferides du Carbonifere Superieur de l'Oural. Geologicheskogo Komiteta, Izvestia (Petrograd), 38(3):279-324. [Date on title page is 1919; actually published in 1924.]

Gemmellaro, G.G.

1899. La Fauna dei Calcari con Fusulina della Valle del Fuime Sosio nella Provincia de Palermo. Giornale di Scienze Naturali ed Economiche di Palermo, 22:59-214, plates 25-36.

George, T.N.

1931. Ambocoelia Hall and Certain Similar British Spiriferidae. Quarterly Journal of the Geological Society of London, 87(1):30-61, plates 3-5.

1932. The British Carboniferous Reticulate Spiriferidae. Quarterly Journal of the Geological Society of London, 88(4):516-575, plates $31-35$.

Gorter, J.D.

1978. Triassic Environments in the Canning Basin, Western Australia. Bureau of Mineral Resources, Journal of Australian Geology and Geophysics, 3(1):25-33.

Grabau. A.W

1931. The Permian of Mongolia. In Chester A. Reeds, editor, Natural History of Central Asia, 4: 665 pages, 35 plates. New York: American Museum of Natural History.

1932. Studies for Students, Series 1: Paleontology: The Brachiopoda. Science Quarterly, National University of Peking, 3:75-112.

1934. Early Permian Fossils of China, I: Early Permian Brachiopods, Pelecypods and Gastropods of Kweichow. Geological Survey of China, Palaeontologica Sinica, series B, 8(3): 168 pages, 11 plates.

1936. Early Permian Fossils of China, II: Fauna of the Maping Limestone of Kwangsi and Kweichow. China Geological Survey, Palaeontologia Sinica, series B, 8(4):1-441, plates 1-31. 
Grant, R.E.

1965. The Brachiopod Superfamily Stenoscismatacea. Smithsonian Miscellaneous Collections, 148(2): 192 pages, 24 plates.

1970. Brachiopods from Permian-Triassic Boundary Beds and Age of Chhidru Formation, West Pakistan. In B. Kummel, and C. Teichert, editors, Straligraphic Boundary Problems: Permian and Triassic of West Pakistan. University of Kansas Special Publication, 4:117151, 3 plates.

1971. Brachiopods in the Permian Reef Environment of West Texas. North Ainerican Paleontological Convention, 1969, J:1444-1481, 22 figures.

1976. Permian Brachiopods from Southern Thailand: Palaeontological Society, Memoir 9. Journal of Paleomology. 50(3) supplement: 269 pages, 71 plates.

Granı, R.E., M.K. Nestell, A. Baud, and C. Jenny

1991. Permian Stratigraphy of Hydra Island, Greece. Palaios, 6:479-487, 7 figures.

Greco, B.

1938. Revisione degli strophomenedi Permiani del Sosio conservati nel Museo di Geologia della Universita di Palermo. Giornale di Scienze Nalıral: ed Economiche di Palerıno, 39(11):1-46, 2 plates.

Grunt, T.A.

1965. Nadsemistvo Athyridacea. In V.E. Ruzhentsev, and T.G. Sarycheva, edilors, Razvitie i smena morskikh organizmov na rubezhe Paleozoia i Mesozoia. Academia Nank SSSR, Paleontoligicheskii Institut, Triudy, 108:237-254, plates 41-44.

Hall, J., and J.M. Clarke

1893. An Introduction to the Study of the Genera of Paleozoic Brachiopoda. New' York Geological Sırvey. 8(2):1-317, 20 plates.

Hou, H.F., L.P. Zhan [L.P. Chan], B.W. Chen, and the Others

1979. The Coal-bearing Strata and Fossils of Late Permian from Gmangtmng. Pages 1-166, 40 plates. P'king: Geological Publishing House.

Huang. T.K.

1932. Late Permian Brachiopods of Southwest China, Part l. Geological Sırvey of China, Palaeontologia Sinica. series B, $9(1)$ : 138 pages, 9 plates.

1933. I.ale Permian Brachiopods of Southwest China, Part 11. Geological Survey of China, Palaeontologia Sinica. series B, 9(2): 172 pages, 11 plales.

Iranian-Japanese Research Group

1981. The Permian and the lower Triassic Systems in Abadeh Region, Central lran. Meinoirs of the Faculty of Science. Kyoto University. Series of (jeology and Mineralogy, 47(2):61-133,6 plates.

Janvier, P.

1989. Breakdown of Trust. In The Peripaletic Fossils, Par 3. Nature, $341: 16$.

Jin, Y.G. [Ching, Y.K., or Jing, Y.G.l, and I).L. Sun

1981. Palaeozoic Brachiopods from Xizang. In Palacontology of Xizang. Book III. The Series of the Scientifir Expedition to the Qinghai.

Kayser, E. Xizang Plateall, pages 127-171. 12 plates. 13eijing: Science Press.

1883. Obercarbonische Fauna von loping. In Fi. von Richthofen, editor, China, volume 4, 269 pages, 54 plates. Berlin: D). Reimer.

King, W.

1850. A Monograph of the Permian Fossils of England. Palaeontolographical Society. Monographss, 3:1-258, 29 plates.

Koczyrkevicz, 13.V.

1979. Novye Permskie R/yynchopora (Brachiopoda) luzhnogo Primorya i nekotorie voprosi ikh morfologii. In M.M. Gramm, editor, Iskopaemye Bespozvonochinye Dal'nego Vosioka (Dannye po Novyn Nakhodkam), pages 41-59, plates 10-13. Vladivostok: Akedemia Nauk.

Kummel, B., and C. Teichert

1966. Relations between the Permian and Triassic Formations in the Salt
Range and Trans-Indus Ranges, West Pakistan. Neues Jahrbuch für Geologie und Paläontologie, Abhandlungen, 125:297-333.

1970. Stratigraphy and Paleontology of the Permian-Triassic Boundary Beds, Salt Range and Trans-Indus Ranges, West Pakistan. In B. Kummel, and C. Teichert, editors, Stratigraphic Boundary Problems: Permian and Triassic of West Pakistan. University of Kansas Special Pmblication, 4:1-1 10.

Liao, Z.T.

1979. Brachiopod Assemblage Zones of Changhsingian Stage and Brachiopods of the Mixed Fauna in South China. Journal of Stratigraphy, 3(3):200-213, 1 plate.

1980a. Upper Permian Brachiopods from Western Guizhou. In Stratig raphy and Palaeontology of Upper Permian Coal-bearing Formation in Westem Guizhou and Eastem Yunnan. Nanjing Institute of Geology and Palaeontology, Academia Sinica, pages 241-277, 9 plates. Beijing: Science Press.

1980b. Brachiopod Assemblages from the Upper Permian and PermianTriassic Boundary Beds, South China. Canadian Journal of Earth Science, 17(2):289-295.

1981. On the Feeding Adaptation of Serpula and the Commensal Relation with Spinomarginifera. Acta Palaeontologica Sinica, 20(2):177178.

1984. New Genera and Species of Late Permian and Earliest Triassic Brachiopods from Jiangsu, Zhejiang and Anhui Provinces. Acta Palaeontologica Sinica, 23(3):276-285, 2 plates.

Liao, Z.T., and F.Y. Meng

1986. Late Changxingian Brachiopods from Huatang of Chen Xian County, South Hunan. Nanjing Institute of Geology and Palaeoniology, Memoir, 22:71-94, 5 plates.

Likharev, B.K.

1934. On Some New Genera of Upper Paleozoic Brachiopoda. Comptes Rendis de L'Académia des Sciences de l'URSS, new series, 1(4):210-213

1936. Uber einige uberpalazoische Galtungen der Terebratulacea aus Eurasien. Problemy Paleontologii, I(1):263-271, 1 plate.

Logan, A., and L.V. Hills, editors

1973. The Permian and Triassic Systems and Their Mutual Boundary. Memoirs, Canadian Society of Petroleum Geologists, 2: 766 pages.

Moore, R.C., edit or

1965. Treatise on Invertebrate Paleontology, Part H: Brachiopoda. Volume 1, 927 pages, 746 figures. Geological Society of America and University of Kansas Press.

Muir-Wood, H.M.

1962. On the Morphology and Classification of the Brachiopod Sinborder Chonetoidea. 132 pages, 16 plates. London: British Museum (Natural History).

Muir-Wood, H.M., and G.A. Cooper

1960. Morphology, Classification and Life Habits of the Productoidea (Brachiopoda). Memoirs. Geological Society of America, 81: 447 pages, 135 plates.

Nakamura, K., D. Shimizu, and Z.T. Liao

1985. Permian Palaeobiogeography of Brachiopods Based on the Faunal P'rovinces. In K. Nakazawa, and J.M. Dickins, editors, The Tethys-Her Paleogeography and Paleobiogeography from Paleozoic to Mesozoic, pages 185-198, figures 1-4. Tokyo: Tokai University Press.

Nakazawa, K., H.M. Kapoor, K.I. Ishii, Y. Bando, T. Maegoya, D. Shimizu, Y. Nogami, and S. Noda

1970. Preliminary Report on the Permo-Trias of Kashmir. Memoirs of the Faculty of Science, Kyoto University, Series of Geology and Mineralogy, 37:163-172, plates 28, 29.

Nakazawa, K., H.M. Kapoor, K. lshii, Y. Bando, Y. Okimura, and T. Tokuoka

1975. The Upper Permian and the Lower Triassic in Kashmir, India. Memoirs of the Facmlty of Science, Kyoto University, Series in Geology and Mineralogy. 47(1): 106 pages. 
Nestell, M.K., and B.R. Wardlaw

1987. Upper Permian Conodonts from Hydra. Greece. Journal of Paleontology, 61(4):758-772.

Newell, N.D., and B. Kummel

1942. Lower Eo-Triassic Stratigraphy, Western Wyoming and Southeast Idaho. Geological Society of America Bulletin, 53:937-995, 3 plates.

North, F.J.

1920. On Syringothyris Winchell and Cerain Carhoniferous Brachiopoda Referred to Spiriferina d'Otbigny. Quarterly Journal of the Geological Society of London, 76(2):162-227, plates 11-13.

Opik. ^.^

1934. Ueber Klitamboniten. Tarm University (Dorpat), Acta et Commentationes, scries A, 26(3): 239 pages, 48 plates.

Pakistan-Japanese Research Group

1981. Stratigraphy and Correlation of the Marine Permian and Lower Triassic in the Surghar Range and the Salt Range, Pakistan. 25 pages. Kyolo, Japan: Kyoto University Press.

1985. Permian and Triassic Systems in the Salt Range and Surghar Range, Pakistan. In K. Nakazawa, and J.M. Dickins, editors, The TethysHer Paleogeography and Paleobiogeography from Paleozoic to Mesozoic, pages 221-294. Tokyo: Tokai University Press.

Rannsbottom. W.H.C.

1952. The Fauna of the Cefn Coed Marine Band in the Coal Measures at Aberbaiden, Near Tondu, Glamorgan. Bulletin of the Geological Survey of Great Britain (Palaeontolog.y). 4:8-32, plates 2, 3.

Rced, F.R.C.

1944. Brachiopoda and Mollusca from the Productus Limestones of the Salt Range. Memoirs of the Geological Survey of India, Palaeontolo-

Rowell, A.J. gia Indica, new series, 23(2):1-678, 65 plates.

1970. Lingula from the Basal Triassic Kathwai Member, Mianwali Formation, Salt Range and Surghar Range, West Pakistan. In B. Kummel, and C. Teichen, editors, Stratigraphic Boundary Problems: Permian and Triassic of West Pakistan. University of Kansas Special Publication, 4:111-116, I plate. Lawrence.

Ruzhentsev, V.E., and T.G. Sarycheva, editors

1965. Development and Change of Marine Organisms at the PalaeozoicMesozoic Boundary. Akademia Nank SSSR. Paleontologicheskii Institut, Trudy, 108:1-431, 58 plates.

Schreter, Z.

1963. Die Brachiopoden aus dem oberen Pern des Bukk-Gebirges in Norungarn. Geologica Hungarica. Palaeontologica. 28:87-179, 9 platcs.

Schuchert, C., and G.A. Cooper

1931. Synopsis of the Brachiopod Genera of the Suborders Orthoidea and Pentameroidea, with Notes on the Telotremata. Ainerican Journal of Science. 22(129):241-251.

1932. Brachiopod Genera of the Suborders Orthoidea and Pentameroidea. Memoirs of the Peabody Musetun of Natural History, 4(1):1-270. plates A, 1-29.

Sheng, J.Z., C.Z. Chen, Y.G. Wang, L. Rui, Z.T. I iao, Y. Bando, K. Ishii, K. Nakazawa, and K. Nakamura

1984. Permian-T'riassic Boundary in Middle and Eastern Tethys. Journal of Hokkaido University. Faculty of Science (Geology and Mineralogy). scries 4, 21(1):133-181, 2 platcs.

Sheng, J.Z., L. Rui, and C.Z. Chen

1985. Permian and Triassic Sedinentary liacies and Paleogeography of South China. In K. Nakazawa, and J.M. Dickins, editors, The Tethys-Her Paleogeography and Paleobiogeography from Paleozoic to Mesozoic, pages 59-81, 14 figures. Tokyo: Tokai University Press.

Siehl. A.

1962. Der Griefensteinerkalk (Eifelium, Rheinisches Schiefergebirge) und sciner Brachiopodenfauna, 1: Geologie, Atrypacea und Rostrospi- racea. Palaeontographica Abteilung A Palaeozoologie Stratigraphie, 119(5-6):173-221, 18 plates.

Sokolskaya, A.N.

1950. Chonetidae Ruskoi Platformy. Academiya Nauk SSSR, Paleontologicheskii Institut, Trudy, 27:1-108, 13 plates.

1965. [Brachiopoda: Rhynchonellida]. In V.E. Ruzhentsev and T.G. Sarylcheva, editors, Razvitie i Smena Morskikh Organizmov na Rubezhe Paleozoia i Mezozoia. [The Development and Change of Marine Organisms at the Palaeozoic-Mesozoic Boundary.] Akademiia Nauk SSSR. Paleontologicheskii Institut, Trudy, 108:233-236. [In Russian.]

Sowerby, J. de C.

1829. Sedgwick Museum, Geological Transactions, series 2(3):119, plate 8, figures $15-18$.

Spath, L.F.

1930. The Eotriassic Invertebrate Fauna of East Greenland. Meddelelser om Groland, 83(1):1-90, plates 1-12.

1934. Catalogue of the Fossil Cephalopoda in the British Museum (Natural History), Part 4: The Ammonoidea of the Trias. xvi + 521 pages, plates 1-18. London: British Museum (Natural History).

Stehli, F.G.

1954. Lower Leonardian Brachiopoda of the Sierra Diablo. Bulletin of the American Musetum of Natural History, 105(3):263-358, plates 18-27.

1961. New Genera of Upper Paleozoic Terebratuloids. Journal of Paleontology, 35(3):457-466, plate 62.

1962. Notes on Some Upper Paleozoic Terebratuloid Brachiopods. Journal of Paleontology, 36(1):97-111, plate 20 .

Stepanov, D.L.

1973. The Permian System in the U.S.S.R. Memoirs, Canadian Society of Petroleum Geologists, 2:120-136.

Stoyanow, A. A.

1910. O novom rode Brachiopoda. Bulletin de l'Academie Imperiale des Sciences de St. Petersbourg, series 6, 4:853-855.

Talent, J.A

1989. The Case of the Peripatetic Fossils. Nature, 338:613-615.

Tasch, P., and P.J. Jones

1979. Carboniferous, Permian and Triassic Conchostracans of Australia, Three New Studies. Bulletin of the Bureau of Mineral Resources, Geology and Geophysics. Australia, 185:1-47, 7 tables.

Teichert, C., B. Kummel, and W. Sweet

1973. Permian-Triassic Strata, Kuh-e-Ali Bashi, Northwestern Iran. Bulletin of the Museum of Comparative Zoology, 145(8):359-472.

Waagen. W.H.

1882-1885. Salt Range Fossils: Productus Limestone Fossils, Part 4(2): Brachiopoda. Memoirs of the Geological Survey of India, Palaeontologia Indica, series 13, 1:329-770, plates 25-86.

Wang, Y.

1955a. New Genera of Brachiopods. Scientia Sinica, 4(2):327-357, 6 plates.

1955b. Phylum Brachiopoda. In Index Fossils of China, book 2, pages 109-171. Beijing: Science Press.

Wang, Y., Y.K. Ching [Y.G. Jin, or Y.G. Jing], and D.W. Fang

1964. Brachiopod Fossils of China. Volume 1:1-354, plates 1-58; volume 2:355-777, plates 59-136. Beijing: Science Press.

1966. Brachiopod Fossils. 702 pages, 567 figures. Beijing: Science Press. Waterhouse, J.B.

1967. Upper Permian (Tatarian) Brachiopods from New Zealand. New Zealand Journal of Geology and Geophysics, 10(1):74-118, 47 figures, 5 plates.

1976. World Correlations for Permian Marine Fauna. University of Queensland Papers, Department of Geology, 7(2):i-xvii + 1-232. 37 figures.

1978. Permian Brachiopoda and Mollusca from North-West Nepal. Palaeontographica, series A, 160:1-175, 26 plates. 
Watchouse, J.B., and V.J. Gupta

1983. An Early Ijulfian (Permian) Brachiopod Faunule from Upper Shyok Valley, Karakorum Rangc, and the Implications for Dating of Allied Faunas from Iran and Pakistan. Contributions to Himalayan Geology, 2:188-233. plates 1-4. Delhi: Hindustan Publishing Corporation.

Waterhouse, J.B., and S. Piyasin

1970. Mid-Permian Brachiopods from Khao Phrik, Thailand. Palaeontographica. series A, 135:83-197, plates 14-32.

White, C.A., and O. St. John

1867. Description of New Subcarboniferous Fossils Collected upon the Geological Survey of lowa: Together with a Notice of New Generic Characters Involved in Two Species of Brachiopoda. Transactions of the Chicago Academy of Science. 1:115-127.

Xu, G.R.

1987. In Z.Y. Yang, H.F. Yin, S.B. Wu, F.Q. Yang, M.H. Ding, G.R. Xu, and Others, Permian-Triassic Boundary Stratigraphy and Fauna of South China. Pages 45-53, 154-157, 215-225, 317-326, plates 7-16. Beijing: Geological Publishing House.

Xu, G.R., and G.C. Liu

1983. [Some Problems in the Research of Triassic Brachiopods.] [In Z.Y. Yang et al.. Triassic of the South Qilian Mountain, pages 67-83.]
Beijing: Geological Publishing House. [In Chinese with English summary.]

Yang, T.Y. [Yang, Z.Y.], P.C. Ting, H.F. Yin, S. Chang, and G.C. Fan

1962. The Brachiopod Fauna of the Carboniferous, Permian and Triassic in the Chi Lianshan Region. Monograph on the Qilianshan Mountains, 4(4):1-134, 48 plates. Beijing: Science Press.

Yang, T.Y. [Yang, Z.Y.], and G.Y. Xu

1966. Triassic Brachiopods of Central Gueizhou (Kueichow) Province, China. 151 pages, 14 plates. Beijing.

Yang, Z.Y. [Yang. T.Y.], H.F. Yin, S.B. Wu, F.Q. Yang, M.H. Ding, and G.R. $\mathrm{Xu}$

1987. Permian-Triassic Boundary Stratigraphy and Fauna of South China. Pages 215-235, plates 7-16. Beijing: Geological Publishing House.

Zhao, J.K., J.C. Sheng, Z.Q. Yao, X.L. Liang, C.C. Chen, L. Rui, and Z.T. Liao 1981. The Changhsingian and Permian-Triassic Boundary of South China. Bulletin, Nanjing Institute of Geology and Paleontology, Academia Sinica, 2:1-95.

Zhao, T.K.

1965. Upper Carboniferous Brachiopods of the Central Part of the Autonomous Region of Inner Mongolia. Acta Palaeontologica Sinica, 13(3):420-454. 




\section{REQUIREMENTS FOR SMITHSONIAN SERIES PUBLICATION}

Manuscripts intended for series publication receive substantive review (conducted by their originating Smithsonian museums or offices) and are submitted to the Smithsonian Institution Press with Form SI-36, which must show the approval of the appropriate authority designated by the sponsoring organizational unit. Requests for special treatment-use of color, foldouts, case-bound covers, etc.-require, on the same form, the added approval of the sponsoring authority.

Review of manuscripts and art by the Press for requirements of series format and style, completeness and clarity of copy, and arrangement of all material, as outlined below, will govern, within the judgment of the Press, acceptance or rejection of manuscripts and art.

Copy must be prepared on typewriter or word processor, double-spaced, on one side of standard white bond paper (not erasable), with $1{ }^{1 / 1}$ margins, submitted as ribbon copy (not carbon or xerox), in loose sheets (not stapled or bound), and accompanied by original art. Minimum acceptable length is 30 pages.

Front matter (preceding the text) should include: title page with only title and author and no other information; abstract page with author, title, series, etc., following the established format; table of contents with indents reflecting the hierarchy of heads in the paper; also, foreword and/or preface, if appropriate.

First page of text should carry the title and author at the top of the page; second page should have only the author's name and professional mailing address, to be used as an unnumbered footnote on the first page of printed text.

Center heads of whatever level should be typed with initial caps of major words, with extra space above and below the head, but no other preparation (such as all caps or underline, except for the underline necessary for generic and specific epithets). Run-in paragraph heads should use period/dashes or colons as necessary.

Tabulations within text (lists of data, often in parallel columns) can be typed on the text page where they occur, but they should not contain rules or numbered table captions.

Formal tables (numbered, with captions, boxheads, stubs, rules) should be submitted as carefully typed, double-spaced copy separate from the text; they will be typeset unless otherwise requested. If camera-copy use is anticipated, do not draw rules on manuscript copy.

Taxonomic keys in natural history papers should use the aligned-couplet form for zoology and may use the multi-level indent form for botany. If cross referencing is required between key and text, do not include page references within the key, but number the keyed-out taxa, using the same numbers with their corresponding heads in the text.

Synonymy in zoology must use the short form (taxon, author, year:page), with full reference at the end of the paper under "Literature Cited." For botany, the long form (taxon, author, abbreviated journal or book title, volume, page, year, with no reference in "Literature Cited") is optional.

Text-reference system (author, year:page used within the text, with full citation in "Literature Cited" at the end of the text) must be used in place of bibliographic footnotes in all Contributions Series and is strongly recommended in the Studies Series: "(Jones, 1910:122)" or "... Jones (1910:122)." If bibliographic footnotes are required, use the short form (author, brief title, page) with the full citation in the bibliography.

Footnotes, when few in number, whether annotative or bibliographic, should be typed on separate sheets and inserted immediately after the text pages on which the references occur. Extensive notes must be gathered together and placed at the end of the text in a notes section.

Bibliography, depending upon use, is termed "Literature Cited," "References," or "Bibliography." Spell out titles of books, articles, journals, and monographic series. For book and article titles use sentence-style capitalization according to the rules of the language employed (exception: capitalize all major words in English). For journal and series titles, capitalize the initial word and all subsequent words except articles, conjunctions, and prepositions. Transliterate languages that use a non-Roman alphabet according to the Library of Congress system. Underline (for italics) titles of journals and series and titles of books that are not part of a series. Use the parentheses/colon system for volume (number):pagination: "10(2):5-9." For alignment and arrangement of elements, follow the format of recent publications in the series for which the manuscript is intended. Guidelines for preparing bibliography may be secured from Series Section, SI Press.

Legends for illustrations must be submitted at the end of the manuscript, with as many legends typed, double-spaced, to a page as convenient.

Illustrations must be submitted as original art (not copies) accompanying, but separate from, the manuscript. Guidelines for preparing art may be secured from the Series Section, SI Press. All types of illustrations (photographs, line drawings, maps, etc.) may be intermixed throughout the printed text. They should be termed Figures and should be numbered consecutively as they will appear in the monograph. If several illustrations are treated as components of a single composite figure, they should be designated by lowercase italic letters on the illustration; also, in the legend and in text references the italic letters (underlined in copy) should be used: "Figure 9b." Illustrations that are intended to follow the printed text may be termed Plates, and any components should be similarly lettered and referenced: "Plate 9 b." Keys to any symbols within an illustation should appear on the art rather than in the legend.

Some points of style: Do not use periods after such abbreviations as "mm, $\mathrm{ft}$, USNM, NNE." Spell out numbers "one" through "nine" in expository text, but use digits in all other cases if possible. Use of the metric system of measurement is preferable; where use of the English system is unavoidable, supply metric equivalents in parentheses. Use the decimal system for precise measurements and relationships, common fractions for approximations. Use day/month/ year sequence for dates: "9 April 1976." For months in tabular listings or data sections, use three-letter abbreviations with no periods: "Jan, Mar, Jun," etc. Omit space between initials of a personal name: "J.B. Jones."

Arrange and paginate sequentially every sheet of manuscript in the following order: (1) title page, (2) abstract, (3) contents, (4) foreword and/or preface, (5) text, (6) appendices, (7) notes section, (8) glossary, (9) bibliography, (10) legends, (11) tables. Index copy may be submitted at page proof stage, but plans for an index should be indicated when the manuscript is submitted. 


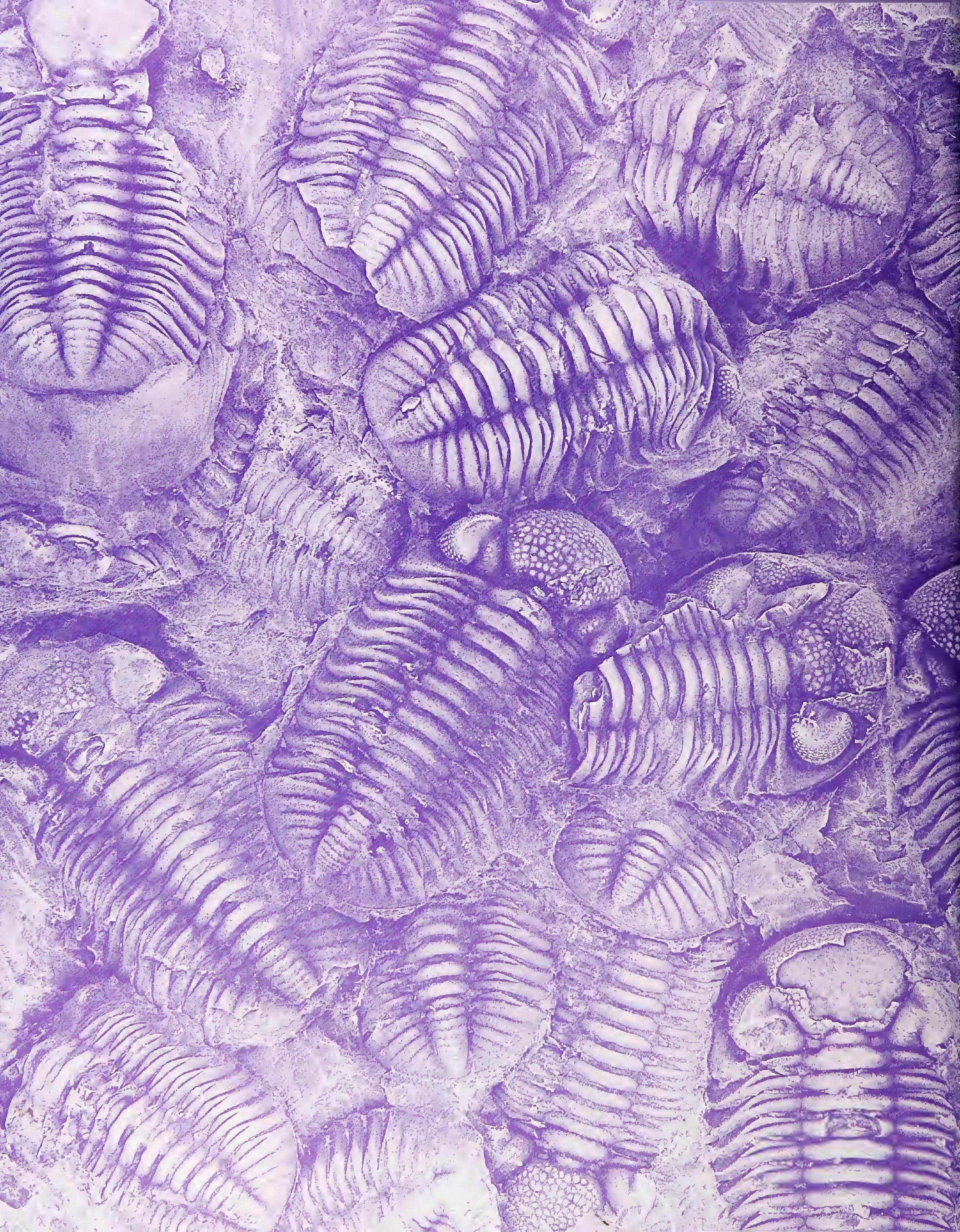

